\title{
LISE DE Lactococcus sp. E PROTEÓLISE EM QUEIJOS FABRICADOS COM ULTRAFILTRAÇÃO E MICROFILTRAÇÃO
}

\author{
LUCIANA ViRIATO SABOYA \\ Engenheira Agrônoma
}

Orientador: Prof. Dr. LUIZ EDUARDO GUTIERREZ Co-orientador: Profa. Dra. ALDA LUIZA SANTOS LERAYER

\begin{abstract}
Tese apresentada à Escola Superior de Agricultura "Luiz de Queiroz", Universidade de São Paulo, para obtenção do título de Doutor em Agronomia, Área de Concentração: Microbiologia Agrícola.
\end{abstract}

PIR A CICABA

Estado-de São Paulo - Brasil

Janeiro - 2002 


\section{Dados Internacionais de Catalogação na Publicação (CIP) DIVISÃO DE BIBLIOTECA E DOCUMENTAÇÃO - ESALQ/USP}

\section{Saboya, Luciana Viriato}

Lise de Lactococcus sp. e proteólise em queijos fabricados com ultrafiltração e microfiltração / Luciana Viriato Saboya. - - Piracicaba, 2002.

218 p. : il.

Tese (doutorado) - Escola Superior de Agricultura Luiz de Queiroz, 2002.

Bibliografia.

1. Autólise 2. Flavor 3. Homogeneização 4. Lactobacilo 5. Lactococcus 6. Maturação 7. Proteólise 8. Queijo I. Título

CDD 637.3

Mermitida a copia to tal ou pa cial deste documento desde que citada a fonte $O$ autor" 


\section{Dedico}

À minha mãe Nadyr,

exemplo de dedicação e amor

Ao meu irmão e amigo Leopoldo, que um dia pedi a Deus

\section{Ofereço}

Aos caros, J.-L. Maubois e Sylvie Lortal, que me ensinaram que a ciência somente é bem sucedida se realizada com paixão 


\section{AGRADECIMENTOS}

Primeiramente, agradeço a Deus por ter tido a chance de realizar esse trabalho, tendo ao lado pessoas maravilhosas que só me fizeram engrandecer!

À Dra. Alda Lerayer, orientadora e amiga, pelo exemplo de sua pessoa, encorajamento e apoio fundamental durante toda a condução desse trabalho.

Aos orientadores franceses, Dr. J.-L. Maubois e Dra. Sylvie Lortal (Lytic Chief), pela amizade, acolhida, oportunidades oferecidas, pelos bons momentos compartilhados e pelo muito que aprendi durante esse tempo.

Ao Prof. Dr. Luiz Eduardo Gutierrez, pela orientação, amizade e confiança na realização deste trabalho.

Ao pessoal do Depto de Agrindústria, Alimentos e Nutricão, pela amizade e apoio, em particular Prof ${ }^{\mathrm{a}}$. Marília Oetterer, bibliotecárias Beatriz Giongo e Midian Gustinelli e dos funcionários Luiz C. Rodrigues, Márcia Bertarelli e Gislaine Nóbilo.

À Ângela e à Amália do escritório da Fapesp na ESALQ, pela amizade e auxílios durante a elaboração e condução deste trabalho.

Aos órgãos financiadores dessa pesquisa: FAPESP (São Paulo, Brasil), CAPES/COFECUB (Brasília, Brasil) e INRA (LRTL, Rennes, França).

Ao pessoal do Laboratoire de Recherches de Technologie Laitière, INRA, pelas facilidades concedidas, auxílio técnico e acolhida, em particular Henri Goudédranche e Jean-Yves Gassi (fabricação dos queijos); Rogé Pantier (análises de proteína), Jacques Fauquant (microfiltração do leite); Anne Thierry e Marie-B. Maillard (CG-MS); Daniel Mollé (HPLC); Michel Piot (análises de aminoácidos livres); Jeannine 
Berrier (microscopia eletrônica); Anne-Marie Renouard, Alexandra Porche e Laurence Fauvel (secretaria); Gaby e Viviane (biblioteca); Paulete e Danièle (materiais).

Aos amigos do Laboratório do INRA, em particular, Marie-No Madec, Sylvie Leroux, Christophe Hervé, Nathalie Roland, Stéphane Pezennec, Valérie Briard, Marie-Caroline, Gabriel, Helle, Frederic e em especial ao "Lytic Club": Stéphane Guezenec, Florence Valence, Stéphanie Deutsch, Nathalie Klein, Linda Tessari, Anthony Neveu e Muriel Derrien, pelos bons momentos de bancada compartilhados e pelo aprendizado do francês "extra-oficial".

A França não teria sido a mesma se não fossem esses amigos "da alegria e da tristeza" que ficarão para sempre guardados em minha memória: Luciano, Maria Soufiane (in memorian), Marie-Agnès Pilard, Paulo, Rosil, Chico, Fred, Marcelo, Elisa, Adilson e Luciane, Paulo e Neiva, Margareth e Udo, Fabíola, Antonio Hamad, MarieFrançoise e Jean-François, Samuel, Bernadet, Caroline, Paco e Federico.

A todos os "velhos" e valiosos amigos que sempre pude contar com apoio e compreensão em todos os momentos: Gisele, Eliana, Érika, Daniela, Ana Maria, Luciane, Fernanda, Raquel, Leila, Viviane, Margarida, Rudy, Carlos.

Aos meus familiares, pelo apoio, carinho, amor, compreensão e incentivos, principalmente de minha mãe Nadyr, de meu irmão Leo e de minha "nhadinha" Vivian. 


\section{SUMÁRIO}

Página

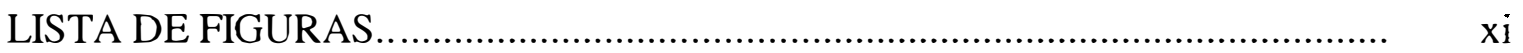

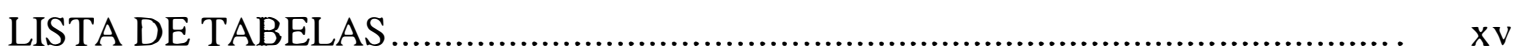

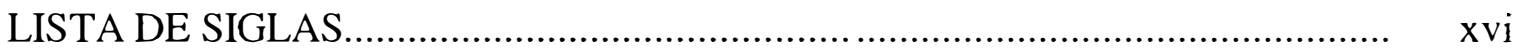

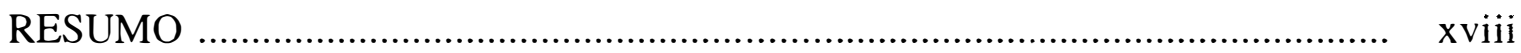

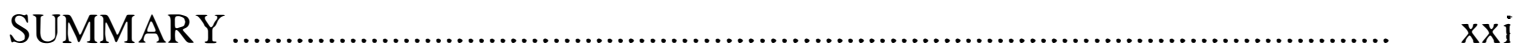

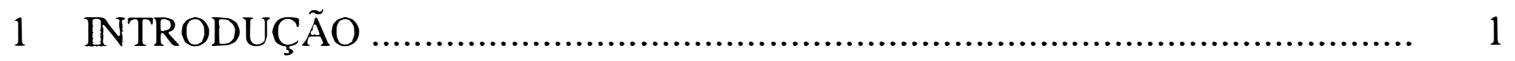

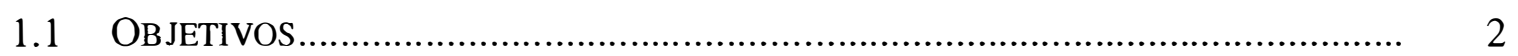

1.2 ESTRUTURA DA APRESENT AÇÃO.................................................................. 3

2 REVISÃO DE LITERATURA...................................................................... 4

2.1 A ULTRAFILTRAÇÃO E O EMPREGO DO PROCESSO MMV ……………………..... 4

2.1.1 Tipos de queijos-UF................................................................................. 6

2.1.1.1 Queijos-UF do tipo fresco ................................................................

2.1.1.2 Queijos-UF maturados..................................................................... 9

2.1.2 Aceleração da maturação de queijos-UF.................................................... 11

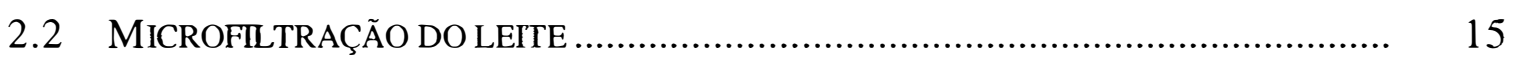

2.2.1 Membranas e equipamento ................................................................. 16

2.2.2 A aplicação da MFT na indústria de laticínios .............................................. 18

2.2.2.1 A MF como meio de remoção de bactérias................................................ 19

2.2.2.2 A MF na obtenção de leite de consumo .................................................... 20 
2.2.2.3 A MF na fabricação de queijos ............................................................ 21

2.2.2.4 Outras aplicações da MF do leite na indústria de laticínios ......................... 23

2.3 AUTÓLISE DE BACTÉRIAS ……………….............................................. 25

2.3.1 Evidências de autólise in vitro de bactérias de interesse em laticínios .......... 26

2.3.2 Métodos de avaliação da autólise de bactérias lácticas em queijos ................ 29

2.3.3 Evidência de autólise de bactérias lácticas em queijos................................... 31

2.4 MATURAÇÃO DE QUEIJOS: PROTEÓLISE E ACELERAÇÃO ………………………... 35

2.4.1 A proteólise durante a maturação de queijos ................................................. 35

2.4.1.1 Proteases do leite, da flora nativa e do coagulante ..................................... 37

2.4.1.2 Enzimas proteolíticas do fermento láctico ............................................... 38

2.4.1.3 Enzimas de microrganismos da flora secundária ....................................... 41

2.4.2 Avaliação da proteólise durante a maturação de queijos ................................ 41

2.4.3 Formação de flavour a partir de produtos da proteólise ………………….... 44

2.4.4 Avaliação dos compostos neutros voláteis do flavour por CG-MS .............. 46

2.4.5 Aceleração da produção de flavour durante a maturação de queijos ............. 48

2.5 ConsideraÇões SOBRe os queIJos SaINT PaUlin E Minas FresCal ............. 50

2.5.1 Saint Paulin....................................................................................... 50

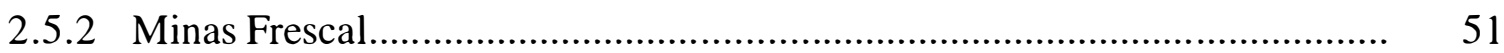

3 ROMPIMENTO MECÂNICO FÁCIL E EFICIENTE DE Lactobacillus helveticus, Lactococcus lactis E Propionibacterium freudenreichii ATRAVÉS DE UM NOVO HOMOGENEIZADOR PILOTO À ALTA PRESSÃO ........................ 54

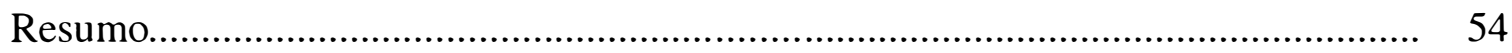

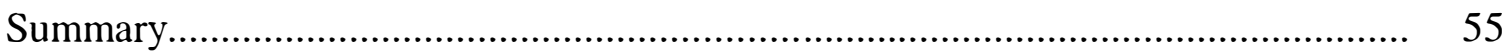

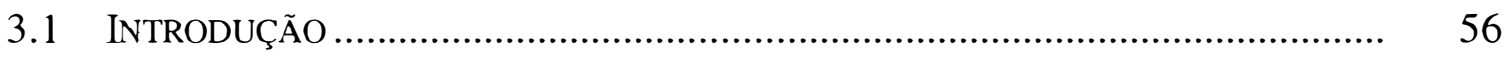

3.2 MATERIAL E MÉTODOS ....................................................................... 58

3.2.1 Origem e crescimento das linhagens ....................................................... 58

3.2.2 Homogeneização....................................................................................... 58

3.2.3 Viabilidade celular ............................................................................ 59

3.2.4 Peso seco celular .............................................................................. 59

3.2.5 Determinação de proteína ........................................................................... 59 


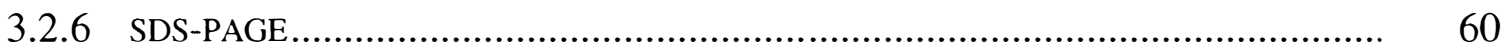

3.2.7 Atividade da leucina-aminotransferase …………....................................... 60

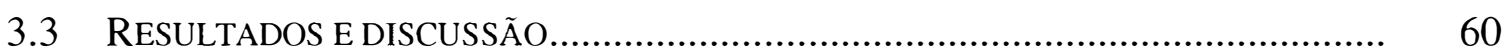

3.3.1 Eficiência do rompimento de células ........................................................... 60

3.3.2 Análises das proteínas liberadas no sobrenadante de homogeneização........ 62

3.3.3 Atividade de leucina-aminotransferase ......................................................... 65

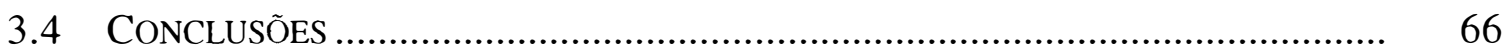

4 IMPACTO DE CÉLULAS ROMPIDAS DE LACTOCOCOS E PROPIONIBACTÉRIA ATRAVÉS DE HOMOGENEIZAÇÃO NA MATURAÇÃO DE QUEJOS ULTRAFILTRADOS: EXTENSÃO DA PROTEÓLISE E PERFIL EM CG-MS. ................................................................... 67

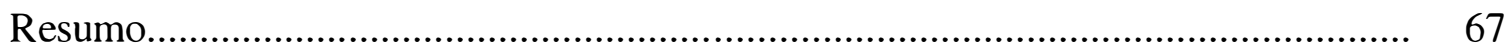

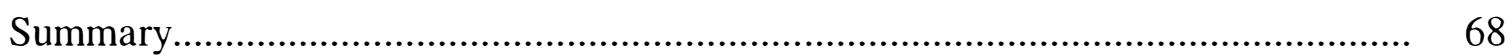

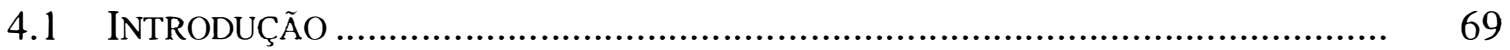

4.2 MATERIAL E MÉTODOS .................................................................. 72

4.2.1 Origem das linhagens e condições de crescimento....................................... 72

4.2.2 Preparo das suspensões celulares e do rompimento de células..................... 72

4.2.3 Ultrafiltração e fabricação dos queijos UF................................................... 73

4.2.4 Composição química dos queijos UF.......................................................... 75

4.2.5 Análises bacteriológicas............................................................................ 75

4.2.6 Extrato aquoso do queijo ......................................................................... 76

4.2.7 Análises em SDS-PAGE …………………………................................ 76

4.2.8 Autólise da cultura láctica acidificante ........................................................ 76

4.2.9 Aminoácidos livres ................................................................................. 77

4.2.10 Compostos voláteis neutros (perfis CG-MS) ……............................................. 78

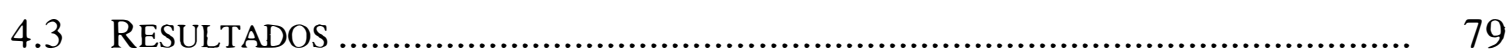

4.3.1 Rompimento de células por homogeneização a alta pressão ............................ 79

4.3.2 Composição química dos queijos em $\mathrm{D}+1$..................................................... 79

4.3.3 Populações bacterianas durante a maturação dos queijos................................ 80

4.3.4 Impacto de homogeneizados de propionibactéria na maturação...................... 82 
4.3.5 Impacto de homogeneizados de lactococos na maturação........................... 83

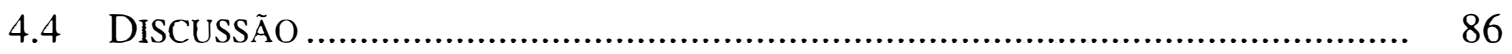

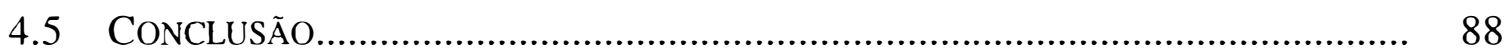

5 COMPORTAMENTO DE LACTOCOCOS COM CARACTERÍSTICAS

AUTOLÍTICAS DISTINTAS EM QUEIJO MINAS FRESCAL,

EMPREGANDO-SE MICROFILTRAÇÃO E ULTRAFILTRAÇÃO ................... 89

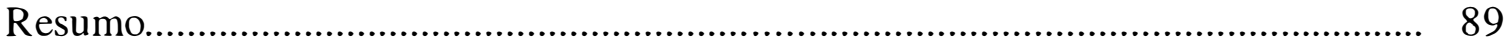

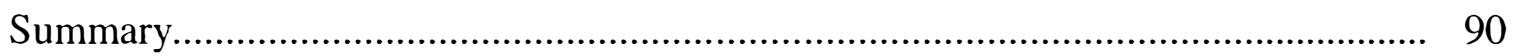

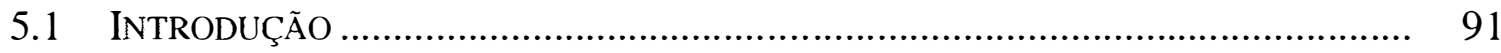

5.2 MATERIAL E MÉTODOS ......................................................................... 93

5.2.1 Origem e cultivo das linhagens ...................................................... 93

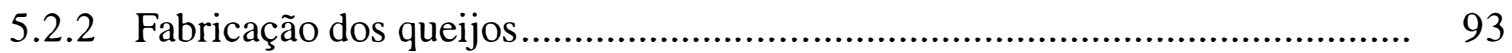

5.2.2.1 Microfiltração do leite ............................................................... 93

5.2.2.2 Fabricação dos queijos tradicionais ................................................ 95

5.2.2.3 Ultrafiltração e fabricação de queijos UF ............................................. 95

5.2.3 Análises físico-químicas do leite e retentado ...................................... 96

5.2.4 Análises físico-químicas dos queijos .............................................. 96

5.2.5 Análises microbiológicas do leite, soro e retentado .............................. 97

5.2.6 Análises microbiológicas dos queijos ................................................ 97

5.2.7 Extrato aquoso do queijo .......................................................... 98

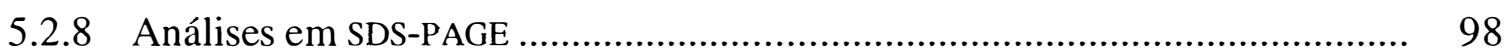

5.2.9 Autólise da cultura láctica.......................................................... 98

5.2.10 Microscopia eletrônica por varredura................................................. 99

5.2.11 Análises de peptídeos em HPLC ..................................................... 99

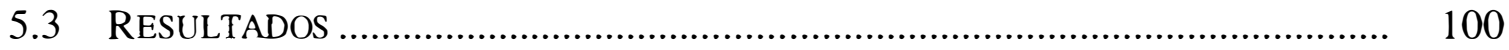

5.3.1 Análises microbiológicas do leite, soro e retentado ............................... 100

5.3.2 Evolução do pH durante a fabricação dos queijos.................................... 100

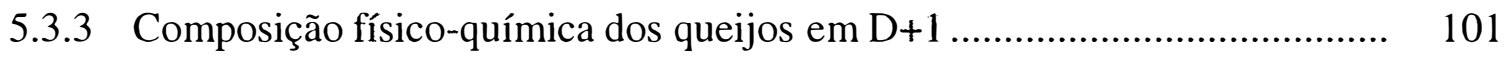

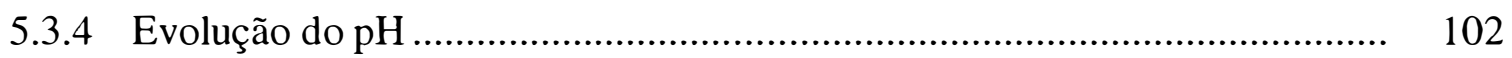

5.3.5 Comportamento autolítico da flora microbiana................................... 103 
5.3.5.1 Viabilidade de lactococos nos queijos ...................................................... 104

5.3.5.2 Verificação da lise de Lactococcus nos queijos através de Immunoblotting.. 105

5.3.5.3 Visualização de bactérias nos queijos tradicionais e ultrafiltrados através de microscopia eletrônica por varredura............................................................... 107

5.3.6 Evolução da proteólise durante o armazenamento ....................................... 109

5.3.6.1 Índice de extensão da proteólise NCN/NT (\%) ........................................ 109

5.3.6.2 Índice de profundidade da proteólise NPN/NT (\%) ................................. 110

5.3.6.3 SDS-PAGE ............................................................................... 111

5.3.6.4 Análises de peptídeos em HPLC............................................................ 112

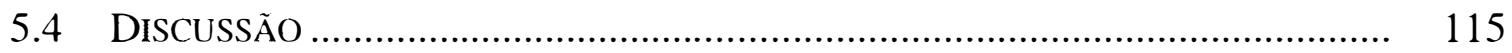

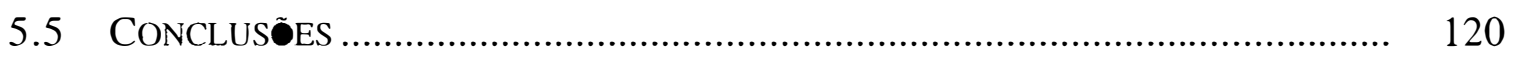

6 CONCLUSÕES GERAIS................................................................. 121

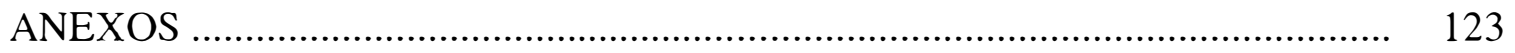

REFERÊNCIAS BIBLIOGRÁFICAS .......................................................... 150

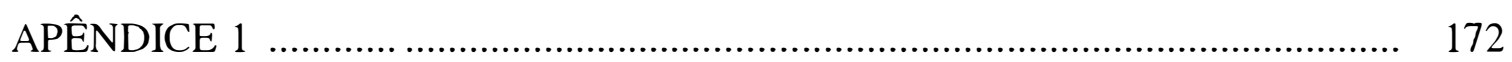

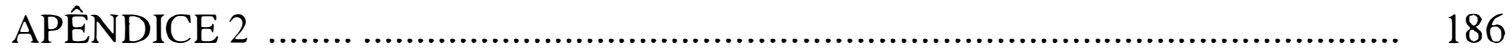

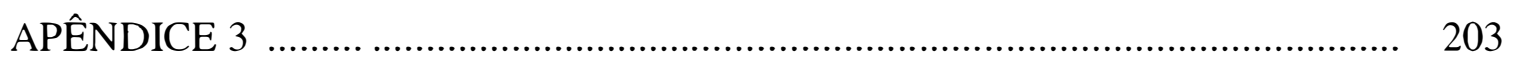




\section{LISTA DE FIGURAS}

Página

1 Esquema comparando os métodos de fabricação de queijos: tradicional e atra vés da Ultrafiltração (Cortesia de J.L. Maubois, INRA, França).................... 5

2 Distribuição dos componentes do leite (adaptado segundo Maubois, 1997b)....... 16

3 Perfis de pressões durante a Microfiltração tangencial (MFT)............................... 18

4 Esquema ilustrativo do impacto da lise de bactérias durante a maturação de queijos (Adaptado de Derrien, 2001).

5 Curva típica de diminuição da D.O. 650 nm, ilustrando a ocorrência da autólise de bactérias na fase estacionária de crescimento. A fotografia mostra a liberação do conteúdo citoplásmático pelas bactérias e duas células intactas (Cortesia de S. Lortal, INRA, França).

6 Principais vias bioquímicas da maturação: (a) proteólise; (b) lipólise; (c) metabolismo da lactose e do citrato (Adaptado de McSweeney \& Sousa, 2000). 36

7 Sistema proteolítico de Lactococcus (Cortesia N. Sørensen, Chr. Hansen, Dinamarca)

8 Principais vias do catabolismo de aminoácidos (Adaptado de Hemme et al., 1982).

$9 \mathrm{DO}_{650 \mathrm{~nm}}$ ( CNRZ 243 (a), L. lactis subsp. lactis NCDO 763 (b) e P. freudenreichii TL 24 (c) quando submetidos à Homogeneização a pressões de 50, 100 e 200 MPa. (---) Curvas de tendência. 
$10 \mathrm{DO}_{280 \mathrm{~nm}}($ (w) subsp. lactis NCDO 763 (b) e P. freudenreichii TL 24 (c) quando submetidos ao Homogeneizador a pressões de 50, 100 e $200 \mathrm{MPa}$.

11 SDS-PAGE mostrando as proteínas de L. helveticus CNRZ 243 (a), L. lactis subsp. lactis NCDO 763 (b) e P. freudenreichii TL 24 (c) liberadas pela homogeneização, dependendo da pressão aplicada (indicada em cada linha). $\mathrm{PM}=$ pesos moleculares padrões $(\mathrm{kDa})$

12 Atividade leucina-aminotransferase $(\mathrm{nmol} / \mathrm{min} / \mu \mathrm{g}$ proteína) de extratos livres de células de $L$. helveticus CNRZ 243, L. lactis subsp. lactis NCDO 763 e $P$. freudenreichii TL 24, obtidos em duas homogeneizações diferentes (A e B) à pressões de 100 (滗), 200 (口) e $200 \mathrm{MPa}$ duas vezes seguidas (W).

13 (a) Contagem do número de células viáveis de Lactococcus sp. em queijos-UF a $12^{\circ} \mathrm{C}$ durante a maturação (• Controle; - CBS 5; $\Delta$ CBS 30; O CFE). (b) Immunoblotting de proteínas citoplasmáticas de Lactococcus no queijocontrole; o tempo dos queijos, em dias, está indicado acima de cada linha (PM = Peso Molecular, kDa; Cyto = proteínas citoplasmáticas de Lactococcus lactis)

14 (a) Contagem do número de células viáveis de Lactococcus sp. ( $\bigcirc$ Controle; CBS; $\triangle$ CFE) e $P$. freudenreichii ( Controle; - CBS; $\triangle$ CFE) em queijosUF tratados com $P$. freudenreichii a $12^{\circ} \mathrm{C}$ e (b) a $20^{\circ} \mathrm{C}$ durante o período de maturação.

15 Relações entre NPN e NT (\%) nos queijos-UF tratados com $P$. freudenreichii e maturados a $12^{\circ} \mathrm{C}$ ( Controle; $\mathrm{CBS} ; \square \mathrm{CFE}$ ) ou a $20^{\circ} \mathrm{C}$ ( $\square$ Controle; $\square \mathrm{CBS}$; $\square \mathrm{CFE}$ ).

16 Composição de aminoácidos livres a $\mathrm{D}+27$ dos queijos-UF Saint Paulin tratados com P. freudenreichii (a) e maturados a $20^{\circ} \mathrm{C}(\square$ Controle; $\square$ CBS; CFE) e em queijos-UF Saint Paulin tratado com Lactococcus (b) a 27 após a fabricação e a $12^{\circ} \mathrm{C}(\square$ Controle; $\square$ CBS 5; $\square$ CBS 30; $\square$ CFE). 
17 Esquema de obtenção do leite microfiltrado (MF) para a fabricação do queijo Minas Frescal pelo processo tradicional e por Ultrafiltração

18 Evolução do pH dos queijos Minas Frescal, fabricados com a linhagem $L$. lactis subsp. cremoris AM2, através de tecnologias tradicional $(\mathbf{\Lambda})$ ou Ultrafiltração (-), ou com L. lactis subsp. cremoris AM2-C e tecnologias tradicional $(\Delta)$ ou Ultrafiltração $(\square)$,durante a estocagem a $5^{\circ} \mathrm{C}$ por 4 semanas.

19 Viabilidade da população de bactérias dos queijos Minas Frescal fabricados com L. lactis subsp. cremoris AM2 através de tecnologias tradicional ( $\boldsymbol{\Delta}$ ) ou Ultrafiltração (-) ou com L. lactis subsp. cremoris AM2-C, e tecnologias tradicional $(\Delta)$ ou Ultrafiltração $(\square)$, durante o armazenamento do queijo Minas Frescal a $5^{\circ} \mathrm{C}$ por 4 semanas.

20 Immunoblotting com citosol de soro anti-lactococos (anti-LC) mostrando a intensidade da autólise das linhagens $L$. lactis subsp. cremoris AM2 ou AM2C no queijo Minas Frescal fabricado através de tecnologias tradicional ou UF em amostras tomadas durante o período de armazenamento $(1,7,14$ e 21 dias). (a) Trad AM2; (b) Trad AM2-C; (c) UF AM2; (d) UF AM2-C. Na primeira coluna de cada Immunoblotting, encontra-se o citoplasma bruto de lactococos (cito), utilizado como referência. A massa molecular padrão de proteínas está indicada ao lado esquerdo de cada blotting.

21 Fotos de microscopia eletrônica por varredura do queijo Minas Frescal fabricado com L. lactis subsp. cremoris AM2 e AM2-C através das tecnologias tradicional e por UF a 48 horas após a fabricação. (a) porção interna do queijo Trad AM2; (b) colônias de lactococos queijo Trad AM2-C; (c) colônias de lactococos no queijo UF AM2; (d) colônias de lactococos no queijo UF AM2-C; (e) microestrutura interna geral do queijo tradicional; (f) microestrutura interna geral do queijo fabricado através de UF. Fotos a, b, c, d: aumento de 10.000 vezes; e, f: aumento de 2.500 vezes. 
22 Evolução dos teores de NCN expressos em \% do NT (índice de extensão da proteólise) durante o armazenamento a $5^{\circ} \mathrm{C}$ de queijos Minas Frescal obtidos por tecnologias tradicional ou UF, com 2 linhagens de L. lactis subsp. cremoris (AM2 ou AM2-C): Trad AM2 (2) Trad AM2-C ( UF AM2

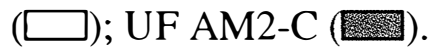

23 Evolução dos teores de NPN expressos em \% do NT (índice de profundidade da proteólise) em queijos Minas Frescal fabricados por tecnologias tradicional ou UF, com 2 linhagens de L. lactis subsp. cremoris (AM2 ou AM2-C): Trad

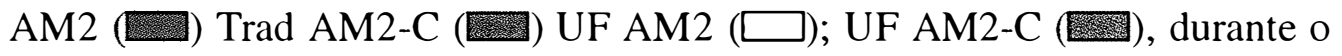
armazenamento a $5^{\circ} \mathrm{C}$.

24 SDS-PAGE dos extratos aquosos de amostras do queijo Minas Frescal tomadas durante o armazenamento a $5^{\circ} \mathrm{C}$, mostrando diferenças no perfil de proteínas, em função do tipo de tecnologia empregada (tradicional ou Ultrafiltração) e da linhagem de L. cremoris utilizada (AM2 ou AM2-C). (a) Trad AM2; (b) Trad AM2-C; (c) UF AM2; (d) UF AM2-C. A massa molecular padrão está indicada ao lado esquerdo de cada figura. ( $\mathrm{PM}=$ peso molecular) $+1,+7+14$ +21: são os dias após a fabricação dos queijos, em que foram tomadas as amostras

25 Perfis cromatográficos de queijos Minas Frescal tradicionais (Trad AM2 e Trad AM2-C) em D+1 e D+14, obtidos através de HPLC. 


\section{LISTA DE TABELAS}

Página

1 Atividade de enzimas intracelulares de espécies bacterianas detectadas em diversos tipos de queijos, indicando a ocorrência de autólise.............................. 32

2 Valores das áreas dos compostos voláteis neutros identificados através de CGMS nos queijos tratados com $P$. freudenreichii (CBS e CFE) em D+27

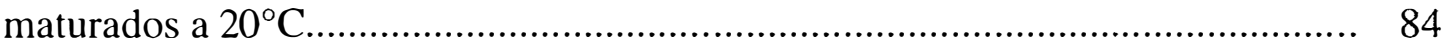

3 Composição físico-química dos queijos Minas Frescal fabricados pelo processo tradicional e por UF um dia após a fabricação. 


\section{LISTA DE SIGLAS}

1) $\mathrm{BHI}=$ Brain Heart Infusion

2) $\mathrm{CBS}=$ Crude Broken Suspension

3) $\mathrm{CFE}=$ Cell Free Extract

4) $\mathrm{CG}-\mathrm{MS}=$ Cromatografia Gasosa com Espectrometria de Massa

5) $\mathrm{CNRZ}=$ Centre National de Recherches Zootechniques, Jouy-en Josas, France

6) DVS = Direct Vat Set (linhagens adicionadas diretamente na cuba)

7) EST $=$ Extrato Seco Total

8) HPLC $=$ High Performance Liquid Chromatography

9) $\quad$ INRA = Institut National de la Recherche Agronomique

10) $\mathrm{LCR}=$ Low Concentration Retentate

11) LRTL = Laboratoire de Recherches de Technologie Laitière

12) $\mathrm{MF}=$ Microfiltração

13) MMV = Maubois - Mocquot - Vassal (processo de UF para a fabricação de queijos)

14) $\mathrm{NCDO}=$ National Collection of Dairy Organisms

15) $\mathrm{NCN}=$ Nitrogênio-Não-Caseínico

16) NPN = Nitrogênio-Não-Protéico

17) $\mathrm{NT}=$ Nitrogênio Total

18) $\mathrm{OR}=$ Osmose Reversa

19) $\mathrm{PCA}=$ Plate Count Agar

20) PTA = Ácido Fosfo-Tungstênio

21) SDS-PAGE = Sodium-dodecylsulphate polyacrilamide gel electrophoresis (Gel de poliacrilamida em dodecil sulfato de sódio). 
22) TCA = Ácido Tricloroacético

23) $\mathrm{TL}=$ Technologie Laitière

24) UESD = Umidade no Extrato Seco Desengordurado

25) UF = Ultrafiltração

26) ufc = unidade formadora de colônia

27) UTP $=$ Uniform Transmembrane Pressure

28) $\mathrm{YEL}=$ Yeast Extract Lactate 


\title{
LISE DE Lactococcus sp. E PROTEÓLISE EM QUEIJOS FABRICADOS COM ULTRAFILTRAÇÃO E MICROFILTRAÇÃO
}

\author{
Autora: LUCIANA VIRIATO SABOYA \\ Orientador: Prof. Dr. LUIZ EDUARDO GUTIERREZ
}

\section{RESUMO}

Diversos trabalhos na literatura demonstram que queijos obtidos por meio do processo de Ultrafiltração do leite, a partir de retentados com fator de concentração acima de cinco ( $\mathrm{fc}>5$ ), maturam lentamente. Muitas hipóteses foram formuladas para explicar tal fenômeno, particularmente com relação à inibição da atividade de certas enzimas endógenas do leite ou à ausência de lise do fermento láctico, limitando a liberação de enzimas intracelulares. A partir dessas hipóteses, propôs-se, neste trabalho, verificar e demonstrar a ausência de lise do fermento láctico em queijos ultrafiltrados e procurar uma alternativa para remediar esse problema tecnológico. Para tanto, adicionaram-se aos retentados de UF ( $\mathrm{fc}=6$ ) para a fabricação de queijo tipo Saint Paulin, diferentes frações celulares de Lactococcus sp. ou Propionibacterium freundenreichii, obtidas através de um novo homogeneizador-piloto à alta pressão. As suspensões de células brutas rompidas (CBS) ou os extratos intracelulares livres de células (CFE) foram obtidos após estudos preliminares de otimização e determinação de pressões específicas a cada espécie, que permitisse a conservação das atividades enzimáticas intracelulares. A lise do fermento láctico foi estudada com o auxílio de marcadores moleculares imunológicos. A evolução da proteólise foi quantificada 
durante o período de maturação por meio da determinação das diferentes formas de nitrogênio (NCN e NPN), de eletroforese (SDS-PAGE) e da formação de aminoácidos livres (HPLC). Os compostos aromáticos voláteis foram identificados somente ao final da maturação através de cromatografia gasosa com espectrometria de massa (CG-MS). Neste trabalho foi demonstrada, pela primeira vez, a ausência de lise nos queijos-UF Saint Paulin, que está implicada na lentidão dos mecanismos de maturação, particularmente em proteólise fraca e produção limitada de moléculas aromáticas. A adição das frações celulares testadas mostrou ser um meio eficaz para acelerar os fenômenos que ocorrem durante a maturação de queijos-UF.

Numa segunda parte deste trabalho, propôs-se aprofundar os estudos das relações existentes entre lise, proteólise e tecnologia de fabricação (tradicional e Ultrafiltração), tomando como modelo o queijo Minas Frescal. Foram utilizadas duas linhagens puras de Lactococcus lactis subsp. cremoris, uma delas lisogênica e altamente autolítica (AM2) e sua variante curada de seu profago, AM2-C, não autolítica. A matéria-prima empregada foi o leite Microfiltrado (membrana com poros de 1,4 $\mu \mathrm{m}$ ) que, com a retirada de 99,98\% das bactérias nele presentes, permitiu avaliar os efeitos dessas duas linhagens sem a interferência de outras espécies. Os queijos obtidos segundo os quatro protocolos experimentais, combinando as duas tecnologias de fabricação com as duas linhagens de lactococos, apresentaram a mesma composição bioquímica após um dia de fabricação. Porém, através da microscopia eletrônica por varredura, pôde-se observar que a microestrutura dos queijos UF era mais homogênea que a dos queijos obtidos pelo processo tradicional. Uma grande diferença quanto à lise das linhagens empregadas foi observada entre queijos obtidos pelo processo tradicional. O emprego da variante curada, resultou em uma proteólise primária bastante intensa. Ao contrário, a linhagem autolítica (AM2) implicou em uma proteólise primária bastante fraca. Parece, portanto, que a lise celular da AM2 afetou a integridade da parede celular e, por consequiência, a atividade da protease ligada à parede celular de L. cremoris. Nos queijos Minas Frescal obtidos pelo processo de UF, independentemente da linhagem utilizada, detectaram-se apenas sinais fracos de lise, levando à conclusão de que ela é praticamente inexistente em tais queijos, quando comparada aos tradicionais. Consequentemente, as 
proteólises primária e secundária foram similares e pouco intensas, confirmando que a lise de lactococos é efetivamente inibida em queijos-UF. A ausência de lise de Lactococcus sp. também foi verificada em queijos-UF existentes no comércio. Os resultados obtidos com queijos Minas Frescal fabricados por UF e com leite desbacterizado através de MF, permitem afirmar que estes queijos evoluem muito pouco durante o período de armazenamento e terão, portanto, uma durabilidade aumentada, constituindo-se de grande interesse para a indústria de laticínios brasileira. 


\title{
Lactococcus sp. LYSIS AND PROTEOLYSE IN ULTRAFILTERED AND MICROFILTERED CHEESES
}

\author{
Author: LUCIANA VIRIATO SABOYA \\ Adviser: Prof. LUIZ EDUARDO GUTIERREZ
}

\section{SUMMARY}

Many investigations in the literature reported that, in cheeses manufactured from UF retentate concentrated up to five fold according to the MMV process, the ripening rates are slower than in traditional cheesemaking processes. Many hypotheses were formulated for explaining this phenomenon. The most frequently formulated one is the inhibition of curd enzymes by the whey proteins. A thorough survey of the published results leads us to the conclusion that the most likely cause was a negative effect of the high buffering power existing in UF retentates on starter lysis, limiting the release of intracellular enzymes. The main purpose of this study was to verify and to demonstrate this hypothesis and then, to develop new innovative ways able to solve this technological problem. For that, propionibacteria and lactococci cells were disrupted using a new pilot homogenizer, in adequate conditions for maintaining active their intracellular enzymes. The resulting crude broken suspensions (CBS), or cell free extract (CFE) separated by centrifugation, were added to UF-Saint Paulin retentates (concentration factor 6:1) added with an usual lactic starter. Autolysis of lactococci was monitored during ripening by immunoblot detection of intracellular proteins. The protein breakdown was estimated by NCN, NPN and free amino acids (HPLC) measurements 
and electrophoresis (SDS-PAGE). Neutral volatile compounds were determined by GCMS at the end of ripening period. The obtained results provide the first demonstration of the absence of Lactococcus starter lysis in UF-Saint Paulin cheeses and clarify the low extent of the ripening through the analysis of the different steps of the cheese proteolysis and the biosynthesis of neutral volatile aroma compounds. The addition of broken cells obtained by high-pressure homogenization appeared to be an efficient way to accelerate the ripening of UF-cheeses.

In a second approach, the aim was to improve knowledge on the mechanisms linking lysis, proteolysis and cheesemaking technology (traditional or use of UF), taking the Minas Frescal cheese as a model. Two single strains of Lactococcus lactis subsp. cremoris were used as starters. One strain was known as lysogenic with high autolytic characteristic (AM2). The other one was its prophage-cured variant, AM2-C, with non-autolytic property. In order to avoid bias with the components of natural milk microflora, the cheese milk was previously microfiltrated (membrane pore size $1,4 \mu \mathrm{m}$ ) that removes $99,98 \%$ of the total initial count. The cheeses made either by traditional process or by ultrafiltration, with the two different starters, showed similar biochemistry composition at day one. On the other hand, scanning electron microscopy showed heterogeneous microstructures in the traditionally processed cheeses contrary to the UF ones that were very homogenous. Autolytic behavior of starters was highly different between the cheeses made by traditional technology. The prophage-cured strain (AM2-C) promoted a very intense primary proteolysis in the cheese at day one contrary to that made with the strain AM2 where the measured proteolysis was very weak. Our results suggest that the cell autolysis of AM2 affect the integrity of the cell wall and, consequently, the activity of the proteases associated. In the case of UF-Minas Frescal cheeses, only weak autolysis signs were detected, whatever was the used strain. Moreover, primary and secondary proteolysis were found low and similar for both strains. These results permit to conclude that the lactococci lysis is almost totally inhibited in such cheeses, when compared to the traditional ones. Absence of Lactococcus sp. lysis was also verified in commercial UF-cheeses. The results concerning the Minas Frescal cheeses made from microfiltered and UF milk allows to 
affirm that these cheeses maintain their characteristics during all the storage period and they will have, therefore, a higher shelf life, that is a great interest for the Brazilian dairy industry. 


\section{INTRODUÇÃO}

O mercado consumidor está, de maneira geral, em contínua demanda por novos produtos lácticos e buscam que tais produtos sejam seguros do ponto de vista higiênico e que apresentem um padrão de qualidade constante. A indústria de laticínios deve, portanto, responder a tais apelos, preocupando-se não somente com aspectos tecnológicos relacionados à produção e à cadeia de frio, que incluem a distribuição e a vida de prateleira dos produtos, mas, sobretudo com os aspectos econômicos, como a utilização de processos menos custosos, que permitam uma valorização otimizada de subprodutos. Assim, é necessário desenvolver novas tecnologias que garantam a segurança higiênica, como o processo de Microfiltração (MF) do leite, e criar novas variedades de queijos, com diferentes texturas, com melhor aproveitamento de resíduos,

como permite o processo de Ultrafiltração (UF). É preciso, ainda, aprofundar os conhecimentos sobre os mecanismos de maturação de queijos a fim de aprimorar e uniformizar a qualidade do produto final.

As tecnologias que utilizam membranas de filtração, em particular a UF, já despertaram o interesse da indústria brasileira. Existem, assim, quatro indústrias de grande porte produzindo queijos do tipo fresco, através do processo MMV que, devido à sua grande aceitabilidade, estão em expansão e contemplam melhorar a qualidade geral do produto, bem como aumentar sua durabilidade. No entanto, elas ainda não se lançaram na produção comercial de queijos-UF maturados; provavelmente porque esses queijos necessitam de um período mais longo de maturação, pois a proteólise ocorre de forma mais lenta, como relata a literatura, e nem todos os mecanismos envolvidos são bem compreendidos até o momento. 
Uma das causas prováveis apontadas pelo retardamento da maturação em queijos-UF é a ausência de lise de bactérias. Assim, uma das finalidades desse trabalho foi estudar a lise do fermento láctico no queijo-UF Saint Paulin, adicionar extratos intracelulares bacterianos para acelerar o processo de maturação e avaliar o seu impacto na proteólise.

Com relação ao queijo Minas Frescal, propôs-se obter um produto com maior durabilidade no comércio, através do emprego do leite microfiltrado no processo de fabricação e avaliar o efeito de linhagens com diferentes características autolíticas na proteólise desse tipo de queijo fabricado com duas tecnologias distintas.

\subsection{OBJetivos}

O objetivo central desse trabalho foi aplicar novas tecnologias que permitam melhorar as qualidades organolépticas e aumentar a estabilidade comercial de dois tipos de queijos, Saint Paulin - escolhido por sua semelhança com o queijo Prato - e Minas Frescal. Para atingir este objetivo, utilizaram-se nesse estudo duas tecnologias modernas envolvendo membranas de filtração do leite: Ultrafiltração e Microfiltração.

Assim, os objetivos específicos incluíram:

- Obter extratos intracelulares de lactococos ou propionibactéria contendo enzimas endógenas ativas, através de um novo homogeneizador-piloto à alta pressão;

- Intensificar a proteólise do queijo Saint Paulin obtido pelo processo de UF, por meio da adição de extratos intracelulares acima citados em retentados $(\mathrm{fc}=6)$ e monitorar a lise de lactococos, avaliando seu impacto sobre a proteólise desse queijo;

- Estudar o comportamento de duas linhagens de lactococos com capacidades autolíticas distintas em queijo Minas Frescal, obtido por dois processos de fabricação, tradicional e Ultrafiltração, utilizando o leite microfiltrado, a fim de controlar o ecossistema bacteriano e de avaliar seu efeito na durabilidade desse queijo. 
A parte prática desse trabalho foi inteiramente desenvolvida no Laboratoire de Recherches de Technologie Laitière (LRTL), em Rennes, pertencente ao Institut National de la Recherche Agronomique (NRA), na França, o qual é uma referência mundial em tecnologias de filtração do leite por membranas. Assim, a finalidade maior desse trabalho é a transferência de tecnologias, particularmente da Microfiltração do leite, técnica esta ainda pouco explorada no Brasil e de tecnologias para a fabricação de queijos UF maturados, visando a melhoria da qualidade dos produtos lácticos nacionais.

\subsection{ESTRUTURA DA APRESENTAÇão}

Este trabalho será apresentado na forma de artigos. A revisão bibliográfica abordará os principais temas envolvidos, quais sejam: Ultrafiltração, Microfiltração, lise bacteriana e proteólise durante a maturação de queijos. Os resultados obtidos neste trabalho de Tese foram organizados em três artigos intitulados: 1) Rompimento mecânico fácil e eficiente de Lactobacillus helveticus, Lactococcus lactis e Propionibacterium freudenreichii através de um novo homogeneizador-piloto à alta pressão; 2) Impacto de células de lactococos ou propionibactéria rompidas através de homogeneização na maturação do queijo UF-Saint Paulin: extensão da proteólise e perfil em CG-MS e 3) Comportamento de Lactococcus com características autolíticas distintas em queijo Minas Frescal, empregando-se Microfiltração e Ultrafiltração. Uma conclusão geral finaliza este trabalho.

Os resultados e Fotos que foram obtidos durante a execução dessa Tese e que não foram apresentados nos artigos, estão inseridos nos Anexos A a E. Os artigos

que foram enviados a revistas científicas e/ou já publicados, constam nos Apêndices 1 a 3. 


\section{REVISÃO DE LITERATURA}

\subsection{A ULTRAFILTRAÇÃO E O EMPREGO DO PROCESSO MMV}

Maubois et al. (1969) propuseram, no final dos anos 60, um processo para a concentração diferencial dos principais elementos do leite, a matéria graxa e as proteínas, empregando-se a técnica de Ultrafiltração (UF) do leite sobre membrana. Esse processo tem como principal característica o uso direto do retentado obtido por UF do leite na fabricação de queijos, dispensando a dessora e o trabalho da massa nos tanques de fabricação, sendo uma alternativa para a produção de queijos. O processo foi patenteado e ficou conhecido mundialmente como MMV, iniciais dos sobrenomes de seus idealizadores - Maubois, Mocquot e Vassal.

$\mathrm{O}$ processo MMV, em linhas gerais, consiste em filtrar o leite integral ou desnatado sob pressões entre 100 e $1000 \mathrm{kPa}$ em membranas com diâmetro de poro de 1 a $10 \mathrm{~nm}$, permitindo a obtenção de dois líquidos: (1) um que passa através da membrana, denominado permeado ou ultrafiltrado, constituído por uma solução aquosa com as moléculas de pequeno tamanho do leite, ou seja, a lactose $(0,8 \mathrm{~nm})$, sais minerais, compostos nitrogenados não-protéicos e vitaminas; (2) outro que é retido pela membrana, denominado retentado ou pré-queijo líquido, que é, na verdade, um leite onde os teores em proteína e em matéria graxa aumentam proporcionalmente à quantidade do permeado retirado, a partir do volume de leite inicial. Adicionando-se fermento láctico, coalho e sal ao retentado, obtém-se, em alguns minutos, um queijo 
com a composição e as dimensões adequadas para a ser comercializado (Figura 1) (Mistry \& Maubois, 1993; Maubois, 1997c).

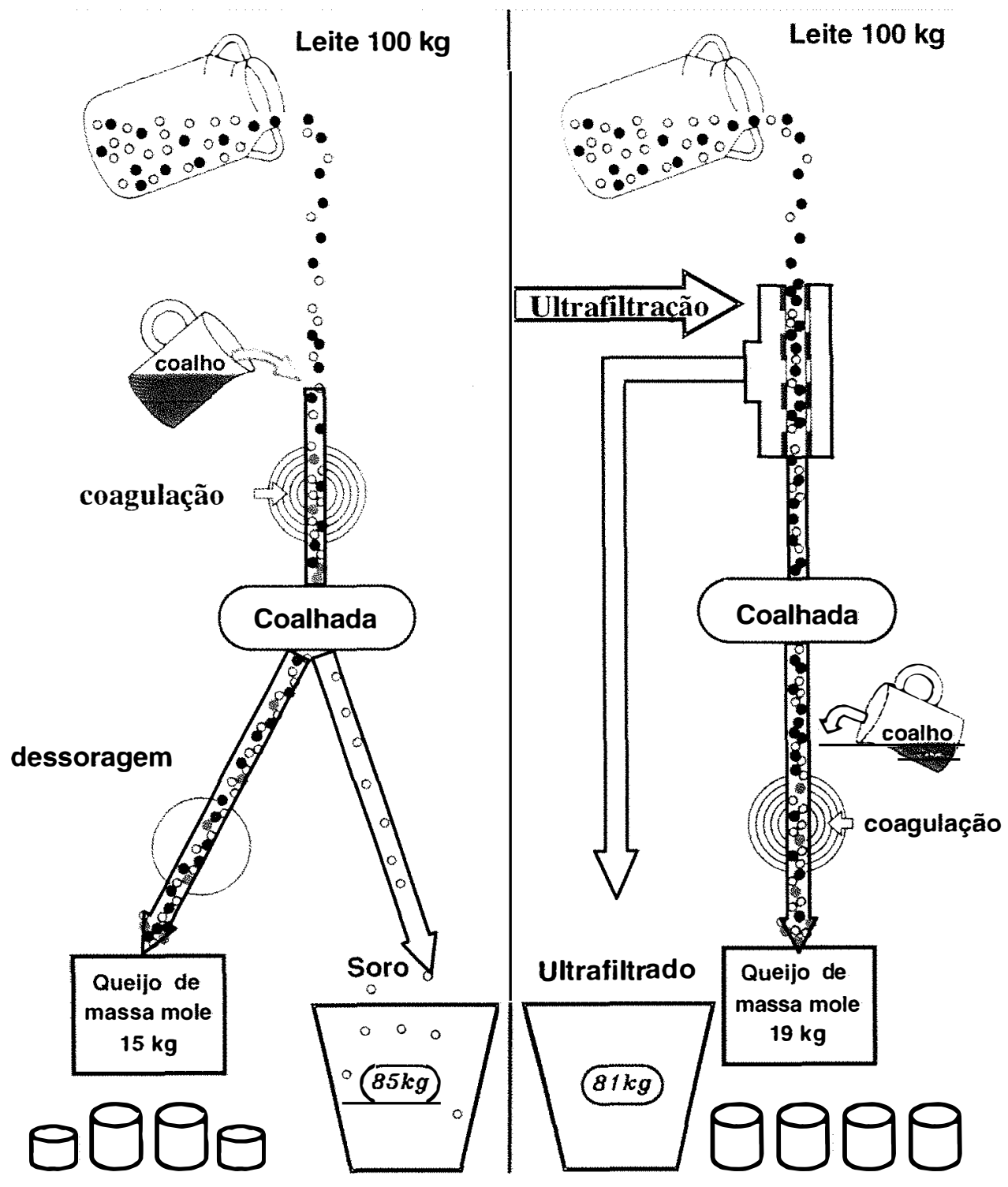

Figura 1 - Esquema comparando os métodos de fabricação de queijos: tradicional e através da Ultrafiltração (Cortesia de J.-L. Maubois, INRA, França).

A aplicação da UF na indústria de queijos tem a principal vantagem de viabilizar o aumento do rendimento do processo, pois permite maior retenção, no queijo, das proteínas solúveis no soro e de toda a gordura do leite. Segundo Saudan et al. (1975), há um aproveitamento líquido de cerca de 8 a $15 \%$ do leite com relação às 
tecnologias clássicas. Na verdade, a retenção da totalidade das proteínas do soro, na forma nativa, acarreta um aumento teórico de rendimento da transformação do leite em queijo de 16 a $22 \%$, dependendo do tipo de queijo. De fato, na maioria das aplicações, esse aumento teórico é inferior àquele realmente constatado, no caso de não haver dessoragem, o que implicará a não ocorrência de perdas em finos de caseína e a retenção do macropeptídeo de caseína no queijo UF ( $5 \%$ em peso das caseínas do leite), que na tecnologia tradicional é solubilizado 80 a $85 \%$ no soro, durante a dessoragem (Maubois, 1997c).

O processo MMV permite, ainda, a economia de coalho, que chega a ser da ordem de $85 \%$, adicionando-se apenas uma dose necessária para a obtenção de um dado período de coagulação, independente da concentração em proteínas do pré-queijo. A homogeneidade, proporcionada pela UF, permite obter queijos de composição e peso semelhantes, portanto padronizados, e de forma contínua. Segundo Van Dender (1999), a produção de queijos por UF possibilita o controle automático de todo o processo, racionalizando e diminuindo a mão-de-obra empregada; a limpeza do equipamento é realizada em circuito fechado, sendo menos laboriosa. Permite, também, uma redução dos custos de construção, pois o equipamento exige menos espaço físico do que uma planta para a produção de queijos tradicionais. Em última análise, o resíduo da UF para a produção de queijos - o permeado, que na realidade corresponde ao soro do queijo, possui menor poder poluente por não conter as proteínas e a gordura do leite.

\subsubsection{Tipos de queijos UF}

Segundo Bech (1993), queijo ultrafiltrado pode ser definido como aquele que foi produzido a partir do leite concentrado por UF, ou seja, a partir do retentado. Os queijos ultrafiltrados podem ser divididos em 3 categorias, segundo a concentração do retentado obtido: (1) queijos fabricados a partir de retentados concentrados 2 vezes; (2) queijos fabricados a partir de retentados concentrados aproximadamente 3 vezes e (3) queijos fabricados a partir de leite inteiramente concentrado (aproximadamente 6 vezes). Os queijos da categoria 1, concentrados até 2 vezes, são fabricados de forma semelhante 
aos queijos tradicionais e a maturação também ocorre de forma parecida, mas não há aumento de rendimento; a grande vantagem, porém, é que com a UF pode-se padronizar o leite e, assim, obter queijos sempre muito similares. O fator de concentração mais utilizado nas indústrias que empregam a UF situa-se, provavelmente, entre 4 a 6 vezes para a produção de Mussarela, Havarti, Danbo, Saint Paulin e Cheddar, quando ocorre de fato aumento de rendimento. No entanto, quando se trabalha com retentados a tais concentrações, o processo de fabricação dos queijos é modificado pelo fato da ausência das etapas de dessoragem e de trabalho da massa. O processo de maturação também é alterado.

Nesta revisão referente à UF e ao processo MMV, será dada ênfase somente aos queijos concentrados de 4 a 6 vezes, que são aqueles que foram utilizados como modelos neste estudo, ou sejam, o queijo Saint Paulin (maturado, semi-duro) e Minas Frescal (fresco, massa mole). A proposição é concentrar-se em aspectos relacionados ao processo de maturação de queijos-UF, abordando a proteólise e o desenvolvimento de sabor, aroma e textura desses queijos.

Os primeiros queijos UF a alcançar escala comercial foram o Cast Feta na Dinamarca e produtos à base de coágulo ácido do tipo fresco como o Quark, a Ricota e o Cream-Cheese na Alemanha. Atualmente, muitas outras variedades de queijos UF já são fabricadas em escala industrial no mundo todo, adaptadas aos hábitos e costumes de cada país, como o Pavé d'Affinois, Camembert e Saint Paulin na França (Goudédranche et al., 1981; Kosikowski, 1985), Feta na Dinamarca e no Iran (Wagner \& Rubin, 1979), Minas Frescal no Brasil (Vieira et al., 1983; Van Dender 1999), Quark na Alemanha (Patel et al., 1986), Twarog na Polônia (Omar \& Hosaja, 1986), Teleme na Grécia (Veinoglou e Boyazoglu, 1982), Ricota e Cream Cheese nos USA (Covacevich \& Kosikowski, 1977; Maubois \& Kosikowski, 1978), e os queijos do tipo duro como o Cheddar ou os do tipo Suíço, fabricados a partir do conceito LCR (low concentration retentate) (Green et al., 1981; Mistry \& Maubois, 1993). 


\subsubsection{Queijos UF do tipo fresco}

Para a fabricação de certos tipos de queijo de massa mole, o processo MMV pode ser usado para preparar um pré-queijo que contém a mesma concentração em gordura e proteína do queijo final. Este concentrado pode ser solidificado pela adição de coalho e do fermento láctico. A fim de que as proteínas do soro permaneçam no queijo, não há drenagem do soro, o que permite um aumento no rendimento na ordem de $15 \%$ (Green et al., 1981).

Os primeiros experimentos envolvendo queijos-UF do tipo fresco, mostraram que estes apresentavam-se com sabor ácido muito pronunciado. Essa acidez excessiva advém do fato que, para atingir um determinado $\mathrm{pH}$, os produtos obtidos por UF contêm mais ácido láctico que os produtos tradicionais (Brulé et al., 1975). Nas fabricações tradicionais de queijos frescos, a sinerese ocorre tanto durante a acidificação da coalhada como após o término dessa fase, resultando numa solubilização de sais minerais complexados pela caseína. Esses sais mineirais assim solubilizados são eliminados durante a dessoragem da coalhada. Ao contrário, se a UF sob membrana é realizada em $\mathrm{pH}$ do leite $(6,6)$, os sais minerais complexados pelas caseínas são concentrados na mesma proporção em que são concentradas as proteínas (Brulé et al, 1974). Esses sais minerais são igualmente solubilizados pela acidificação do retentado, mas não são eliminados porque, pelo processo de UF, a etapa de sinerese da coalhada é suprimida. Em razão do efeito tamponante causado por esse teor superior em minerais nos pré-queijos líquidos, a quantidade de ácido láctico a ser desenvolvida pelas bactérias do fermento láctico para atingir um determinado $\mathrm{pH}$, é mais elevada que aquela em queijos obtidos por processos tradicionais (Brulé et al., 1975). Na tentativa de suprimir esse defeito (sabor ácido acentuado dos queijos), esses pesquisadores sugeriram ultrafiltrar o leite a um $\mathrm{pH}$ mais baixo, ou seja, realizar uma pré-maturação no leite por bactérias lácticas, ou ainda, concentrar o mais possível o retentado, até um fator de concentração próximo de 6,5 e em seguida, diluí-lo. No entanto, essa última conduta somente tornou-se viável com a utilização de aparelhos equipados com uma nova geração de membranas de UF, de natureza mineral, que possuem maior resistência 
mecânica e físico-química, surgidas no início dos anos 80. Goudédranche et al. (1981) sugeriu que, para controlar a elevada acidez do queijos obtidos por UF, pode-se interromper o processo de acidificação resfriando o pré-queijo mas com o risco de uma retomada da atividade dos fermentos lácticos ou ainda, eliminando a lactose residual do pré-queijo por diafiltração antes do fermento láctico ser inoculado.

Por algum tempo, a maioria dos processos comerciais usados para a fabricação de queijos frescos caracterizava-se pela UF do leite acidificado por cultura láctica até $\mathrm{pH}$ 4,4-4,6, de forma a obter produtos mais similares aos tradicionais, evitando a formação de sabor amargo ou muito ácido (Mahaut et al., 1986; Nielsen, 1987). No entanto, devido à facilidade e à viabilidade prática, possibilitada pelo surgimento das membranas minerais de UF, tem-se dado preferência a diafiltrar o retentado e, em seguida, inocular o fermento desejado, controlando-se a acidificação até um valor de $\mathrm{pH}$ desejado, como proposto por Goudédranche et al. (1981).

Exemplos bem sucedidos da aplicação do processo MMV na produção de queijos frescos com alto teor de umidade incluem queijos do tipo Ricota, Minas Frescal e queijos do tipo coalhada acidificada, como o Quark e o Cream Cheese (Covacevich \& Kosikowski, 1977; Vieira et al., 1983; Lawrence, 1989; Van Dender et al., 1999).

\subsubsection{Queijos UF maturados}

O sucesso do processo MMV é explicado através das vantagens econômicas, principalmente devido ao aumento no rendimento de fabricação proporcionado pela incorporação das proteínas do soro na coalhada (Goudédranche et al., 1981; Lawrence 1989; Pedersen \& Ottosen, 1992). No entanto, quando se trata de queijos fabricados a partir de retentados de UF concentrados 5 vezes ou mais, ou seja, queijos duros ou semi-duros, foi demonstrado pela literatura especializada que a sua maturação queijos é bastante distinta daqueles fabricados pela tecnologia tradicional, ocorrendo de forma mais lenta (de Koning et al., 1981; Hickey et al., 1983; Spangler et al., 1989). Isso significa que a proteólise e o desenvolvimento do sabor e aroma (flavour) nesses queijos são retardados, mesmo possuindo idêntica composição bioquímica 
(sólidos totais - EST, gordura no EST desengordurado) aos queijos tradicionais (Covacevich \& Kosikowski, 1978; Bech, 1993).

Essa maturação atípica dos queijos UF foi relatada em queijo Cheddar-UF (Green et al., 1981; Hickey et al., 1983; Creamer et al., 1987), Edan-UF (El-Shabrawym, 1985), Havarti-UF (Qvist, 1987), demonstrada principalmente através dos teores de NPN (nitrogênio-não- protéico, solúvel em TCA a 12\%).

Os fatores que alteram a proteólise dos queijos UF têm sido motivo de muita discussão entre pesquisadores da área e várias hipóteses foram postuladas. A maioria dos estudos aponta que esse fato advém da incorporação das proteínas do soro pelo processo de UF (de Koning et al., 1981; Hickey et al., 1983; Lawrence, 1989; Bech, 1993), que parecem não ser degradadas, ou degradadas de forma restrita durante a maturação (Qvist, 1987; de Koning et al., 1981) e dependentes de estarem em seu estado nativo ou desnaturadas (Jameson \& Lelievre, 1996). Há pesquisadores que acreditam que a causa dessas proteínas não serem degradadas está relacionada à presença de alguns inibidores de proteases e peptidases concentrados nos queijos UF (Hickey et al., 1983); há cientistas que indicam que a $\beta$-lactoglobulina inibe a ação da plasmina, que por sua vez catalisa a hidrólise primária da $\beta$-caseína (Bastian et al., 1991; Bech, 1993). Já foi também apontado que a quantidade de coagulante residual não seria suficiente para um desenvolvimento normal da proteólise em queijos UF. Já Mistry \& Maubois (1993) acreditam que a principal razão para a maturação ser lenta é a elevada capacidade tamponante dos queijos UF, que faz com que as reações bioquímicas fiquem comprometidas como, por exemplo, a autólise do fermento láctico que ocorre tardiamente (Goudédranche et al., 1986) e consequentemente, a hidrólise da caseína e dos peptídeos.

Explicando melhor a hipótese com relação ao poder tamponante de retentados, quando o leite é filtrado em seu $\mathrm{pH}$ normal $(6,7)$, os sais minerais $(\mathrm{Ca}, \mathrm{Mg}$, P) associados à micela de caseína são concentrados na mesma proporção que as caseínas. Isso resulta em aumento do poder tampão do retentado de UF, que provavelmente influencia os parâmetros de processamento, como cinética de acidificação, pH final, cinética de coagulação pelo coalho, características reológicas da 
coalhada e do queijo maturado, atividade das enzimas envolvidas na maturação, crescimento e desenvolvimento do ecossistema bacteriano de maturação (Maubois, 1997c). Já em 1974, Brulé et al. sugeriram várias maneiras para ajustar o conteúdo mineral dos retentados de UF: 1) reduzindo o $\mathrm{pH}$ do leite antes ou durante a UF de 6,6 para 6,0 , o que leva a um aumento do cálcio no permeado de 0,38 para $0,50 \mathrm{~g} / \mathrm{kg} ; 2$ ) aumentando a força iônica pela adição do $\mathrm{NaCl}(0,5$ a $0,9 \%)$, ou associando ambos os métodos (Mistry \& Maubois, 1993).

As proteínas do soro incorporadas nos queijos UF, além de modificarem o a proteólise e o desenvolvimento do flavour nesses queijos, interferem também no desenvolvimento da textura, por motivos ainda não completamente esclarecidos (Lelievre \& Lawrence, 1988). De Koning et al. (1981) postularam a hipótese de que as proteínas do soro incorporadas nos queijos fabricados pelo processo MMV são como um enchimento inerte, devido à sua resistência à hidrólise pela quimosina, às proteases do fermento láctico e à plasmina. Quanto mais proteína do soro presente, maiores serão as diferenças nas propriedades funcionais do queijo, o que, segundo Lawrence (1989), não é necessariamente uma desvantagem. Alguns pesquisadores observaram que a textura de queijos UF é mais macia (De Koning et al., 1981; Maubois \& Kosikowski, 1978; Goudédranche et al., 1986). A textura do queijo UF Casta Feta, por exemplo, é diferente daquela do Feta tradicional, mas isso não afeta o seu sucesso comercial. De Koning et al. (1981) e Lawrence (1989), sugeriram que essa maciez obtida nos queijos UF é uma particularidade interessante para o desenvolvimento de queijos semi-duros com baixo teor de gordura.

\subsubsection{Aceleração da maturação de queijos UF}

Devido às alterações constatadas nos queijos-UF que necessitam maturação, onde a evolução da proteólise ocorre de forma mais lenta, alguns pesquisadores sugerem aplicar os mesmos métodos usados para acelerar a maturação de queijos tradicionais aos queijos-UF, ou seja, 1) aumento da temperatura de maturação (Fox, 1989); 2) adição de fermentos atenuados (Klein \& Lortal, 1999); 3) adição de 
extratos livres de células (Engels \& Visser, 1996); 4) aumento da população microbiana ou de bactérias que não sejam as do fermento láctico; v) adição de proteases ou lipases ou vi) combinação de métodos (Fox, 1989; El Soda \& Pandian, 1991; El Soda, 1993). Algumas dessas ferramentas já foram investigadas em queijos UF e serão relatadas a seguir.

Hickey et al. (1983) adicionaram uma linhagem termofílica, com elevada capacidade proteolítica, Lactobacillus helveticus YB1, juntamente com o fermento láctico, em queijo Cheddar fabricado através de UF a fim de intensificar a formação de sabor e aroma. Eles verificaram que o nível de aminoácidos livres nesse queijo aumentou em relação àquele observado no queijo fabricado pelo processo tradicional, obtido somente com a linhagem L. lactis subsp. cremoris E8.

A fim de melhorar a textura, o sabor e o aroma dos queijos Saint Paulin e Camembert fabricados por UF, Goudédranche et al. (1986) adicionaram 0,5 ou 1,0 g/kg de lisozima nos pré-queijos líquidos, na tentativa de promover a lise do fermento láctico com conseqüente liberação de enzimas intracelulares. Esses pesquisadores observaram um pequeno aumento na proteólise durante a maturação e um melhoramento nas qualidades organolépticas nesses queijos.

Qvist et al. (1987) fabricaram queijos Havarti a partir de retentado de UF concentrado 5 vezes, adicionando fermento DVS contendo L. lactis subsp. lactis, $L$. lactis subsp. cremoris, L. lactis subsp. diacetylactis (cultura láctica tipo BD), a fim de promover maior produção de sabor e aroma e os compararam a queijos Havarti tradicionais, normalmente fabricados com os fermentos L. lactis subsp. lactis e L. lactis subsp. cremoris. Os queijos UF adicionados da cultura tipo BD foram similares aos queijos tradicionais com relação a cor, sabor, aroma e textura. No entanto, o desenvolvimento de flavour nesses queijos, um pouco menos pronunciado, foi associado com a degradação protéica mais lenta, particularmente da $\beta$-caseína. Concluíram que o emprego da cultura aromática é um meio interessante para melhorar a qualidade do queijo-UF Havarti.

Visando aumentar o desenvolvimento de sabor e aroma do queijo Gouda fabricado a partir de leite ultrafiltrado, Spangler et al. (1989) utilizaram protease 
bacteriana na forma livre ou encapsulada; também adicionaram uma mistura de protease encapsulada em lipossomas e células de Lactobacillus helveticus atenuadas por choque frio (freeze shocked) e compararam a queijos tradicionais. Os queijos tradicionais tratados com enzimas livres tiveram um aumento no nitrogênio solúvel em TCA, mas desenvolveram um sabor amargo pronunciado. Esse sabor amargo foi significativamente reduzido quando as enzimas estavam encapsuladas em lipossomas, embora tenha sido observado o oposto em se tratando dos queijos-UF. Já nos queijos adicionados com bactérias atenuadas e protease encapsulada em lipossomas, observaram os maiores níveis de nitrogênio solúvel em TCA. Esse tratamento foi indicado como um meio eficiente para reduzir o tempo de maturação de queijos UF, porém laborioso.

Bastian et al. (1991), adicionando uroquinase aos queijos-UF Havarti e Saint Paulin com a intenção de ativar a plasmina, observaram um aumento nos níveis de NPN e de NCN e uma maior degradação da $\beta$-caseína que foram correlacionados com o pequeno aumento no sabor e aroma.

Bech, em uma revisão com o propósito de caracterizar a maturação de queijos UF em 1993, sugeriu adicionar quantidades extras de proteases e peptidases de bactérias para aumentar a hidrólise secundária da caseína, na tentativa de melhorar a maturação de tais queijos. Foi essa a linha de pesquisa seguida, numa parte desse trabalho, quando foram adicionados extratos intracelulares de lactococos ou propionibactérias no queijo-UF Saint Paulin, com a finalidade de promover um impacto na proteólise.

Resumindo, diversos tipos de queijos fabricados a partir de Ultrafiltração são produzidos em grande escala em todo o mundo. A principal razão do sucesso do processo MMV é econômica, com o aumento de rendimento de fabricação e necessidade de menor quantidade de coalho. Além disso, o processo MMV exige pouca manipulação durante a obtenção dos queijos e permite a total padronização dos mesmos, refletindo em qualidade constante do produto final. No entanto, o maior problema enfrentado é com relação aos queijos UF que 
necessitam ser maturados, pois a formação de produtos responsáveis pelo sabor e aroma ocorrem de forma menos intensa e requerem um maior período de tempo, quando comparados aos queijos obtidos pelo processo tradicional. As causas desse problema não foram ainda totalmente estabelecidas. Atualmente, muitas pesquisas estão sendo focadas no sentido de intensificar a proteólise e aumentar a formação de produtos relacionados aos compostos responsáveis pelo aroma e sabor desses queijos. 


\subsection{MICROFILTRAÇÃO DO LEITE}

A Microfiltração (MF), como qualquer outro processı de separação por membranas, é uma técnica que permite a concentração diferencial no líquido retido pela membrana, o chamado retentado de MF, de componentes com tamanho maior que o diâmetro médio do poro da membrana. O líquido que passa através da membrana é denominado microfiltrado e contém os componentes de tamanho menor do que a média do diâmetro do poro (Saboya \& Maubois, 2000). É a mais antiga das tecnologias por membranas, com numerosas aplicações na esterilização do ar e da água. No entanto, a utilização da Microfiltração Tangencial (MFT) nos tratamentos de líquidos alimentares é recente, sendo a última a alcançar escala industrial (Cohen-Maurel, 1990).

O conceito de separação por MFT pode ser aplicado apenas agora, devido a 2 inovações tecnológicas que ocorreram no início dos anos 80: 1) o desenvolvimento de novas membranas minerais, que possuem maior resistência mecânica ao cisalhamento elevado e 2) o conceito hidráulico de pressão uniforme entre membranas (UTP uniform transmembrane pressure) que permite reverter o entupimento causado durante o processo de separação (por re-circulação do microfiltrado contra fluxo ao circuito do retentado e pela utilização de um gradiente de porosidade longitudinal na membrana) (Maubois, 1997a).

A utilização da MFT para separar os microrganismos dos componentes do leite é possível devido às diferenças existentes entre a distribuição de tamanho das micelas de caseína e das bactérias mais freqüentemente encontradas no leite, como mostra a Figura 2 (Maubois 1997b). Em ordem decrescente, os compostos do leite estão assim distribuídos: células somáticas (15-6 $\mu \mathrm{m})$, glóbulos de gordura $(15-0,2 \mu \mathrm{m})$, bactérias (6-0,2 $\mu \mathrm{m})$ e micelas de caseína (0,3-0,03 $\mu \mathrm{m})$ (Pierre et al., 1998).

A Figura 2 mostra que os glóbulos de gordura apresentam tamanhos similares aos da maioria das bactérias. Para evitar uma concentração em gordura e, 
consequentemente problemas técnicos de entupimento da membrana, a gordura deve ser removida por separação antes do procedimento de MF.

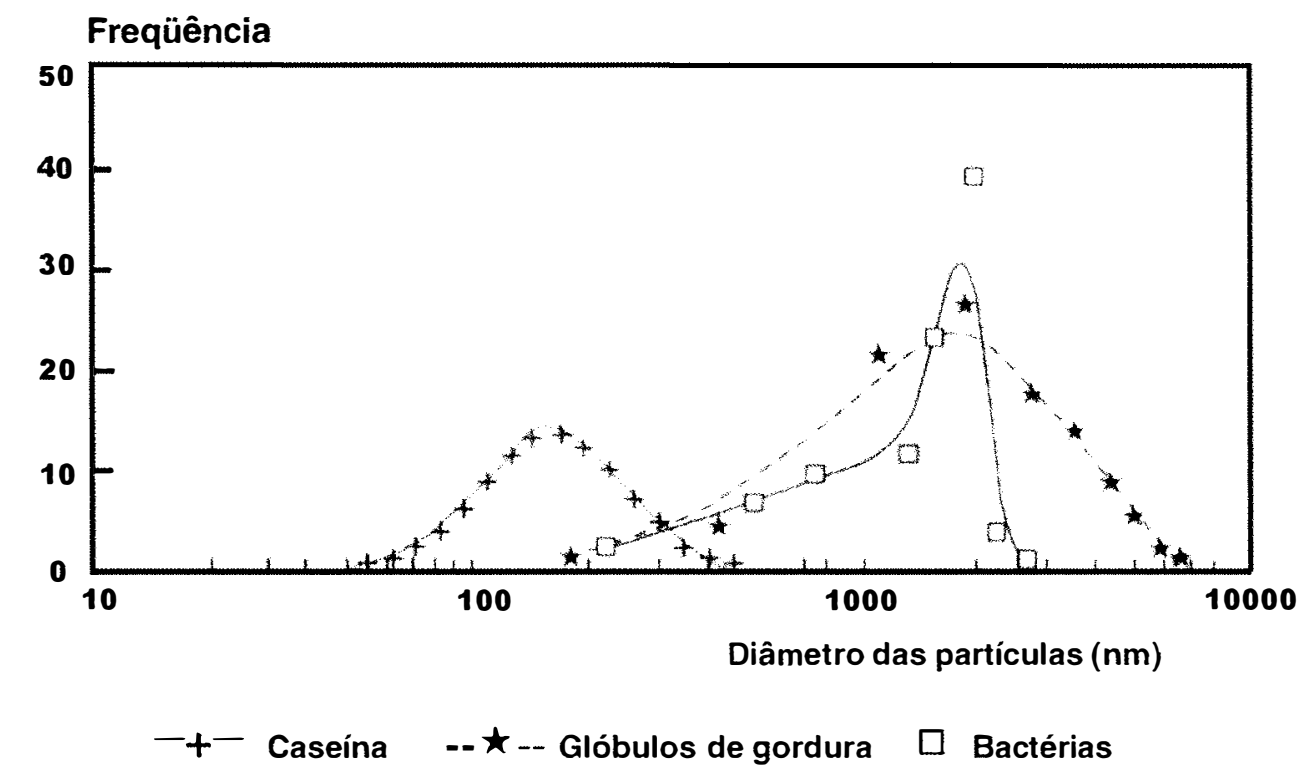

Figura 2 - Distribuição dos componentes do leite (adaptado segundo Maubois, 1997b).

\subsubsection{Membranas e equipamento}

A eficiência de qualquer tecnologia de separação por membranas é estabelecida por vários parâmetros, entre eles, os materiais que constituem a membrana e o seu suporte e a hidrodinâmica de todo o equipamento (Saboya \& Maubois, 2000).

O grande avanço da MF na indústria de laticínios ocorreu com o desenvolvimento de novas membranas que substituíram aquelas fabricadas a partir de materiais orgânicos como polissulfono e policarbono (Jost \& Jelen, 1997). Atualmente, as membranas utilizadas em MF são à base de cerâmica (Gillot \& Garcera, 1984) que, de início, foram desenvolvidas para o enriquecimento de isótopos na indústria nuclear.

O diâmetro de poros das membranas de MF é compreendido entre 20 e $0,1 \mu \mathrm{m}$. As membranas são constituídas por 2 partes: um suporte macroporoso e a 
membrana ativa revestindo a superfície. Os materiais de suporte, feitos de alumina (o mais desenvolvido), carbono, aço inoxidável ou SiO, devem drenar o permeado sem qualquer resistência hidrodinâmica e, portanto, possuir um diâmetro de poro da ordem de $10 \mu \mathrm{m}$. A camada da membrana, geralmente composta de alumina, óxido de titânio ou de zircônio, ou mistura de ambos óxidos, é formada por uma suspensão coloidal em pó altamente dividida (mais que $100 \mathrm{~m}^{2} / \mathrm{g}$ ), revestindo o suporte. A espessura da membrana é cerca de 3-5 $\mu \mathrm{m}$ (Grandison \& Finnigan, 1996).

Essa nova geração de membranas (terceira geração) confere estabilidade tanto química como térmica; não há problemas quanto ao fluxo e a seletividade, o que corresponde a todas as exigências da indústria de laticínios. Os problemas com entupimento das membranas foram contornados com a utilização do conceito da pressão uniforme entre membranas (UTP), conforme proposto por Sandblom (1974). Sugere-se recircular o permeado de MF em condições tais de fluxo, de forma que a pressão entre membranas seja baixa e uniforme ao longo de toda a membrana (Figura 3). Desses dois avanços tecnológicos, as novas membranas e a UTP, resultou o processo-equipamento denominado Bactocatch, comercializado pela Tetra-Laval (Meersohn, 1989).

No processo Bactocatch, após a retirada da gordura através de centrifugação, o leite desnatado cru é colocado em contato com uma membrana com diâmetro de poros de $1,4 \mu \mathrm{m}$, à temperatura entre 35 e $50^{\circ} \mathrm{C}$. A velocidade de recirculação do retentado é da ordem de 7,5 a $8,5 \mathrm{~m} / \mathrm{s}$. O diferencial de pressão entre membranas é uniforme e igual a 0,55 bar. A relação (FCV, fator de concentração volumétrico) existente entre a vazão do leite na entrada e a vazão do retentado na saída é igual a 20. De acordo com os esquemas tecnológicos próprios das empresas fabricantes dos equipamentos, diferentes tratamentos são aplicados ao retentado de MF (contendo as bactérias): 1) tratamento térmico (pasteurização ou esterilização UHT) para emprego na alimentação animal; 2) mistura com uma quantidade de creme necessária à padronização do leite de fabricação, seguida de um tratamento térmico variando entre uma pasteurização HTST e uma combinação tempo temperatura de $115-125^{\circ} \mathrm{C}$ por 3 a 10 segundos, seguindo-se da mistura assim tratada, no microfiltrado; 3) Microfiltração complementar em cascata com um FCV de 10, levando a uma concentração total de 
elementos retidos pela membrana dentro de 0,5\% do leite tratado (Maubois, 1997b). Porém, atualmente somente a opção de número (1) tem sido aconselhada a ser utilizada (aproveitamento do retentado para uso animal) pela sociedade que fabrica esse equipamento.

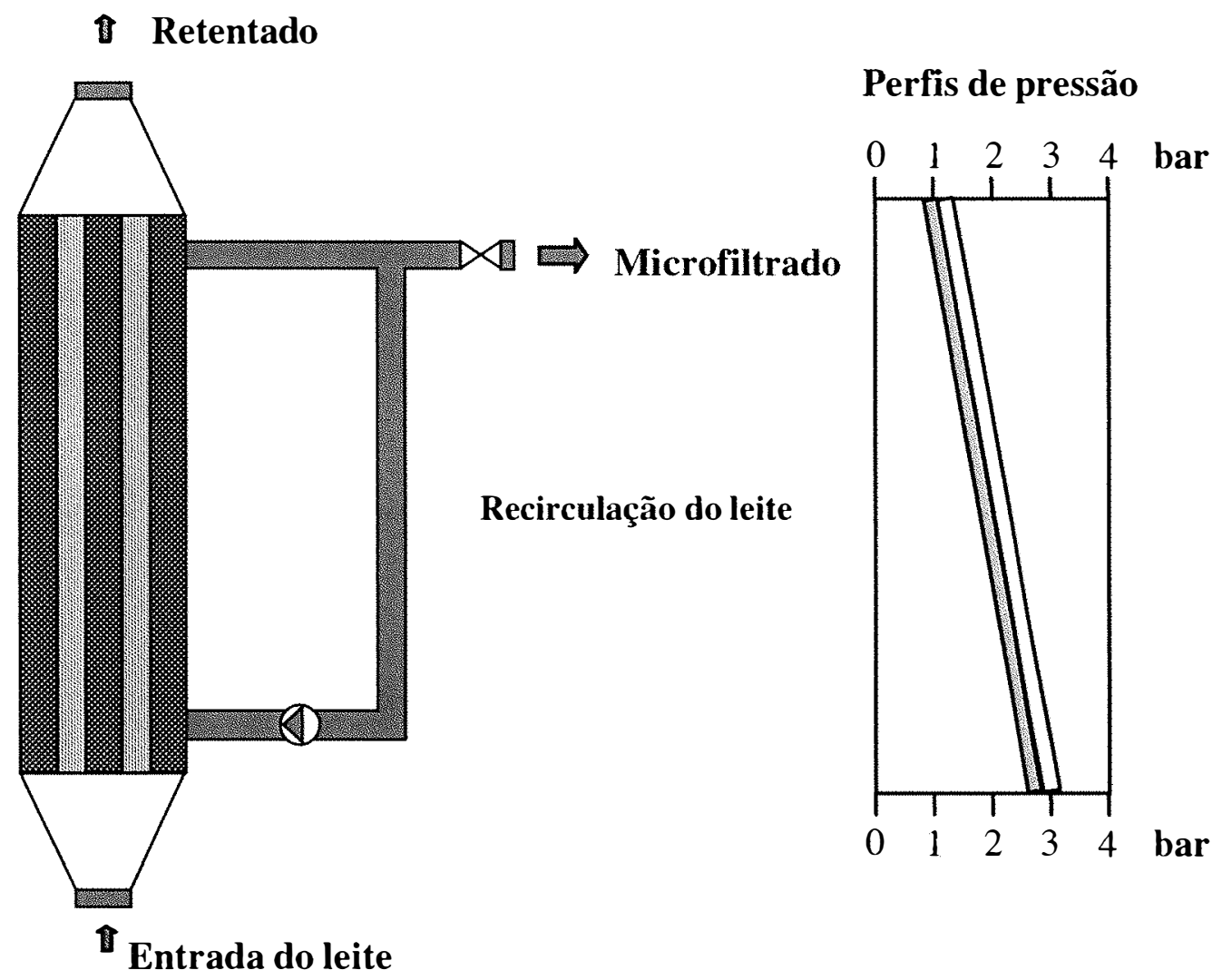

Figura 3 - Perfis de pressões durante a Microfiltração tangencial (MFT) Processo Tetra-Laval.

\subsubsection{A aplicação da MFT na indústria de laticínios}

A MFT surgiu como uma tecnologia de separação industrial na indústria de laticínios, com 3 principais aplicações: remoção de bactérias do leite, retirada de gordura do soro resultante da fabricação de queijos e enriquecimento da caseína micelar para a fabricação de queijos. No entanto, outras inúmeras aplicações estão sendo 
estudadas, como por exemplo, a separação seletiva de células somáticas do leite cru, o fracionamento de proteína do leite ou soro, a separação de glóbulos de gordura e tratamento da salmoura. Essas aplicações somente são passíveis de serem executadas devido à existência, no mercado, de uma vasta gama de membranas cerâmicas com vários tamanhos de poros, como por exemplo, 1,4,08, 0,5 e 0,1 $\mu \mathrm{m}$, empregados de acordo com a finalidade desejada ou requerida (Saboya \& Maubois, 2000).

\subsubsection{A MF como meio de remoção de bactérias}

A maior aplicação da MF na indústria de laticínios consiste na remoção de microrganismos do leite desnatado, resultando numa matéria-prima ausente de bactérias, que posteriormente pode ser destinada ao consumo in natura, para a fabricação de queijos, leites fermentados ou produtos lácticos de longa estocagem, como pós ou derivados protéicos (Fauquant et al., 1988; Saboya \& Maubois, 2000).

A eliminação de bactérias do leite usando membranas de MF resulta em melhoramento geral na qualidade bacteriológica e higiênica dos diversos produtos dele derivados. Essas membranas retiram praticamente todos os microrganismos contidos no leite, quer sejam patogênicos ou não e ainda eliminam as células somáticas e os esporos. Madec et al. (1992) observaram reduções decimais (RD) de Listeria monocytogenes, Brucella abortus, Salmonella typhimurium e Mycobacterium tuberculosis na ordem de $3,4,4,0,3,5$ e 3,7, respectivamente. Tais resultados asseguram que o leite desnatado MF contém menos de 1 ufc/l dessas bactérias patogênicas, considerando-se as contaminações comumente descritas nos locais de ordenha. A eficiência de retirada quase completa de microrganismos e esporos (99,9 a 99,999\%), independente de sua carga inicial, sem a necessidade de aplicação de temperaturas elevadas durante o

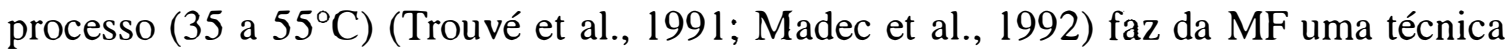
atraente, devido à atual busca por alimentos assegurados no plano qualidade e higiene alimentar.

Quanto às células somáticas, quando encontradas no leite num nível acima de $4 \times 10^{5} \mathrm{ccs} / \mathrm{ml}$, podem induzir a defeitos detectáveis nos produtos lácteos, tais como lipólise e proteólise demasiadamente aumentada e perda de rendimento na 
fabricação de queijos (Andrews, 1983; Everson, 1984). Essas células, evidentemente, são todas retidas pela membrana de $\mathrm{MF}$ e, consequentemente, o leite microfiltrado não será degradado pelas enzimas termodúricas de leucócitos (Law \& Goodenough, 1995). Observa-se um melhoramento no rendimento, nas características sensoriais e na qualidade higiênica de produtos de longa duração, como leite fluido e queijos (Maubois, 1997a).

Como vantagem adicional, a MF do leite não promove alterações nas qualidades nutricionais e organolépticas dos compostos sensíveis aos tratamentos térmicos como as proteínas e vitaminas. Com isso, obtém-se um produto diferenciado com características sensoriais naturais, ou seja, o sabor do leite microfiltrado é muito semelhante ao do leite cru, mas de qualidade microbiológica excepcional (Charvet \& Maubois, 1994).

\subsubsection{A MF na obtenção de leite de consumo}

Atualmente, a MF está abrindo um novo mercado nos países europeus e norte-americanos para o consumo do leite in natura com vida útil aumentada cerca de 3 a 5 vezes, quando comparada aos tratamentos clássicos dados ao leite. Existem 3 categorias de leite de consumo microfiltrado que já são comercializadas em alguns países e que são dependentes do tipo de tratamento ao qual esse leite foi submetido. $\mathrm{Na}$ França, por exemplo, até o momento, somente uma categoria de leite microfiltrado é comercializada e possui o nome comercial de Marguerite ${ }^{\circledR}$ (Foto: Anexo A2). Esse é um leite fosfatase positiva, ou seja, um leite com características de leite cru. Sua durabilidade é de quinze dias sob refrigeração $\left(6^{\circ} \mathrm{C}\right)$, contra 3 dias para o leite cru normal de boa qualidade microbiológica (Charvet \& Maubois, 1994). No Canadá e na maioria dos países da Europa do Norte, assim como na Argentina, o leite MF é também pasteurizado, o que permite uma durabilidade de 35 dias sob refrigeração $\left(6^{\circ} \mathrm{C}\right)$, contra 10 dias para o leite pasteurizado normal. No Canadá, e em breve na França, é produzido, em escala piloto industrial, um leite microfiltrado estéril por MF especial, seguido de um tratamento térmico de $96^{\circ} \mathrm{C} / 6$ segundos e embalagem asséptica, o que permite uma 
conservação por um período ainda maior de, no mínimo, 3 meses à temperatura ambiente $\left(20-25^{\circ} \mathrm{C}\right)$ (Maubois, 2001 comunicação pessoal).

Esses leites possuem grande aceitação por parte dos consumidores em razão de suas qualidades organolépticas iniciais que são conservadas durante o período de armazenamento do produto: total ausência de gosto de cozido e de sabor amargo (Maubois, 1997a).

\subsubsection{A MF na fabricação de queijos}

O leite MF tem sido matéria de vários estudos envolvendo a elaboração de queijos, principalmente no sentido de compará-lo àqueles fabricados com leites pasteurizado e cru. Já existem relatos na literatura sobre o emprego de leite MF na fabricação de vários tipos de queijos (McSweeney et al., 1993; Bouton \& Grappin, 1995; Beuvier et al., 1997; Rodriguez et al., 1999; Maubois et al., 2000).

Inicialmente, o leite MF foi sugerido para a elaboração de queijos que necessitam longo período de maturação, pois com a remoção de esporos, que normalmente resistem ao tratamento térmico, não haveria ricos de estufamento tardio, eliminando a adição de nitrato (Meershon, 1989). Foi também proposto como uma tecnologia alternativa para assegurar aos consumidores de queijos fabricados com leite cru, total segurança higiênica. Obviamente, o leite MF deve ser inoculado novamente com um ecossistema microbiano adequado, capaz de manter a tipicidade de cada queijo (Maubois et al., 2000). No entanto, à medida em que pesquisas com leite MF avançaram, foi sendo observado que a flora banal do leite possui um importante papel na formação de olhaduras (queijos do tipo Suíço), textura, sabor e aroma dos queijos, visto que quando somente a cultura láctica era adicionada, resultava em queijos bastante distintos daqueles fabricados com leite cru ou pasteurizado (Beuvier et al., 1997; Maubois et al., 2000).

Assim, uma outra área de pesquisa está surgindo graças à aplicação do leite MF na fabricação de queijos, permitindo a caracterização e a determinação do papel de cada microrganismo no processo de maturação, sem que haja desvios de resultados ocasionados pelo tratamento térmico do leite. $\mathrm{O}$ estudo do ecossistema microbiano no 
queijo e o das interações existentes entre a flora banal do leite e as bactérias do fermento láctico permitirão uma melhor escolha de linhagens quando destinadas à fabricação de queijos, em função do local de origem.

McSweeney et al. (1993), a fim de estudar a contribuição da flora endógena do leite na maturação do queijo Cheddar, fabricaram queijos a partir de leite cru, de leite pasteurizado $\left(72^{\circ} \mathrm{C}, 15 \mathrm{seg}\right)$ ou de leite microfiltrado desnatado (unidade de MF Alfa Laval MFS-1) padronizado com creme pasteurizado $\left(72^{\circ} \mathrm{C}, 30 \mathrm{seg}\right)$, maturados a $10^{\circ} \mathrm{C}$. Os queijos e seus extratos solúveis em água, quando analisados em gel de uréiapoliacrilamida (PAGE), mostraram-se indistinguíveis até 3 meses de maturação, tendo sido detectada alguma diferença após 6 meses. Os perfis em peptídeos foram similares entre os queijos pasteurizados e microfiltrados, mas diferentes para o queijo fabricado com leite cru. A concentração de aminoácidos livres foi muito mais elevada no queijo fabricado a partir de leite cru do que nos queijos fabricados com leite MF ou pasteurizado. A concentração do ácido glutâmico livre também foi mais elevada no queijo fabricado com leite cru do que nos outros dois. Esse mesmo queijo exibiu concentração mais elevada em ácidos graxos livres durante a maturação. A microflora não-fermentadora (non-starter), constituída principalmente de Lactobacillus spp., diferiu nos queijos fabricados a partir de leite cru e pasteurizado. Os resultados mostraram que a MF diminuiu de forma eficiente o número de microrganismos da flora endógena no leite e no queijo. Esses autores puderam concluir que a flora endógena do leite afeta de forma decisiva a qualidade do queijo Cheddar fabricado com leite cru.

Bouton \& Grappin (1995) compararam a qualidade de queijos de massa cozida prensada (Comté) fabricados a partir de leite cru ou microfiltrado (aparelho Bactocatch, com membrana de poro de 1,4 $\mu \mathrm{m}$ ). Foi evidenciado o papel da flora nativa do leite na proteólise e na formação do sabor e aroma do queijo, analisando-se índices de proteólise, eletroforese em gel de poliacrilamida e a fração nitrogenada solúvel por cromatografia líquida de alta performance (CLHP). Após 4 meses de maturação, a composição físico-química e a qualidade sensorial dos queijos mostraram-se diferentes. Os queijos fabricados com leite MF continham menos aminoácidos e peptídeos de cadeia curta, quando comparados aos queijos fabricados com leite cru. A esses queijos, 
foram atribuídos sabor amargo, produção mais fraca de aroma e menor acidez. Esse estudo mostrou que, de forma geral, os queijos fabricados a partir de leite cru possuíam melhor qualidade organoléptica que os queijos fabricados a partir de leite MF. Concluiuse, portanto, que a flora nativa influencia a formação de sabor e aroma nesse tipo de queijo.

Beuvier et al. (1997) fabricaram mini-queijos a partir de leite cru, microfiltrado, pasteurizado $\left(72^{\circ} \mathrm{C}, 30 \mathrm{seg}\right)$ ou pasteurizado misturado ao retentado de Microfiltração, para estudar a influência da microflora nativa e da pasteurização na qualidade de um queijo do tipo Suíço. Esses pesquisadores concluíram que ao final da maturação, os queijos fabricados com leite cru e com o retentado de Microfiltração mostraram produção de aroma e sabor mais marcantes, quando comparados aos queijos fabricados com leite MF e pasteurizado. Essas características foram correlacionadas com elevadas populações de lactobacilos heterofermentativos $\left(10^{8} \mathrm{ufc} / \mathrm{g}\right)$, propionibactérias $\left(10^{8} \mathrm{ufc} / \mathrm{g}\right)$ e enterococos $\left(10^{6} \mathrm{ufc} / \mathrm{g}\right)$. Esses queijos mostraram, ainda, níveis elevados de nitrogênio solúvel em PTA e em ácidos acético, propiônico e isovalérico. Os queijos fabricados com leite MF e pasteurizado, embora um tanto distintos um do outro, estavam bastante diferentes dos outros dois tipos de queijos. Os queijos fabricados com leite pasteurizado tiveram um $\mathrm{pH}$ mais baixo que os queijos com leite $\mathrm{MF}$ e continham uma maior proporção de $\gamma$-caseína devido à ativação pela plasmina. Apesar de mais ácidos, demonstraram uma intensidade global maior em aromas. A adição da flora do retentado ao leite pasteurizado restaurou quase todas as características bioquímicas e sensoriais dos queijos fabricados com leite cru avaliadas nesse estudo.

\subsubsection{Outras aplicações da MF do leite na indústria de laticínios}

Muitos outros processos envolvendo a MF estão sendo aplicados na indústria de laticínios mas em menor escala, quando comparado à MF do leite de consumo, na retirada de células somáticas e bacterianas (incluindo esporos) (Saboya \& Maubois, 2000). A MF é utilizada também com sucesso para separar, de acordo com o diâmetro de poros das membranas, a partir do leite desnatado, o fosfocaseinato de cálcio 
(Pierre et al., 1992) e certas frações da caseína (beta-caseína, kapa-caseína); no fracionamento das principais proteínas do soro (Merin et al., 1983; Maubois et al., 1987); na separação da gordura do leite em pequenos e grandes glóbulos para a produção de produtos com novas texturas (Goudédranche et al., 2000); na purificação da salmoura de queijos, a fim de prevenir que sejam contaminados durante a etapa da salga (Pedersen, 1992; Ottosen \& Koni gsfeld, 1999).

Em suma, diversas são as possibilidades de aplicação da Microfiltração, mas aquela que está despertando maior atenção atualmente é a do leite, utilizando membranas com poros de $1,4 \mu \mathrm{m}$, como meio de remoção de bactérias, esporos e células somáticas. O leite microfiltrado para consumo já atingiu o comércio de países europeus e norte-americanos e tem sido também utilizado como uma ferramenta importante no estudo de floras microbianas específicas em queijos.

A presente revisão foi baseada num artigo redigido durante o período deste trabalho, "Current developments of microfiltration technology in the dairy industry", publicado na Revista Le Lait (v.80, p.541-553, 2000) e encontra-se no Apêndice 1. 


\subsection{AUTÓliSE DE BACTÉRIAS}

Dentre os três principais fenômenos que ocorrem durante a maturação de queijos, a glicólise, a lipólise e a proteólise, este último é o mais expressivo. A degradação da caseína do leite por proteases, peptidases, esterases e enzimas do catabolismo de aminoácidos de bactérias lácticas tem sido indicada como o ponto-chave para o desenvolvimento da textura, do sabor e aroma típicos de cada tipo de queijo (Fox, 1989; Visser, 1993; Crow et al., 1995). Entre essas enzimas, as peptidases são melhor caracterizadas; elas liberam peptídeos de cadeia curta e aminoácidos livres, percursores de aromas. A ação das peptidases contribui, ainda, para a diminuição do sabor amargo em queijos (Figura 4). Após ter sido estabelecido que a localização das peptidases de Lactococcus é intracelular (Monnet et al., 1993; Tan et al., 1992), vários pesquisadores (Crow et al., 1995; Chapot-Chatier, 1996; Lortal et al., 1997) passaram a estudar com mais intensidade o fenômeno da autólise em bactérias lácticas, a fim de melhor compreender de que modo as enzimas intracelulares são liberadas na matriz do queijo, quais os fatores determinantes e como controlar tal fenômeno.

A lise de bactérias é definida como um fenômeno de ruptura celular espontâneo, devido à hidrólise da cadeia de peptideoglicano por enzimas localizadas na parede celular, as chamadas autolisinas (Rogers et al., 1980; Shockman \& Höltje, 1994) ou devido à atividade hidrolítica de uma enzima codificada por um profago denominada endolisina, encontrada em bactérias lisogênicas (Sable \& Lortal, 1995). Em geral, esse fenômeno ocorre espontaneamente após a fase estacionária e já foi observado em várias espécies, gram positivas ou gram negativas. As células perdem sua integridade, abremse e liberam seu conteúdo citoplasmático (enzimas metabólicas, enzimas proteolíticas, ácidos nucléicos, aminoácidos, etc.) no meio em que se encontram (Figura 5) (Lortal, 1995). 


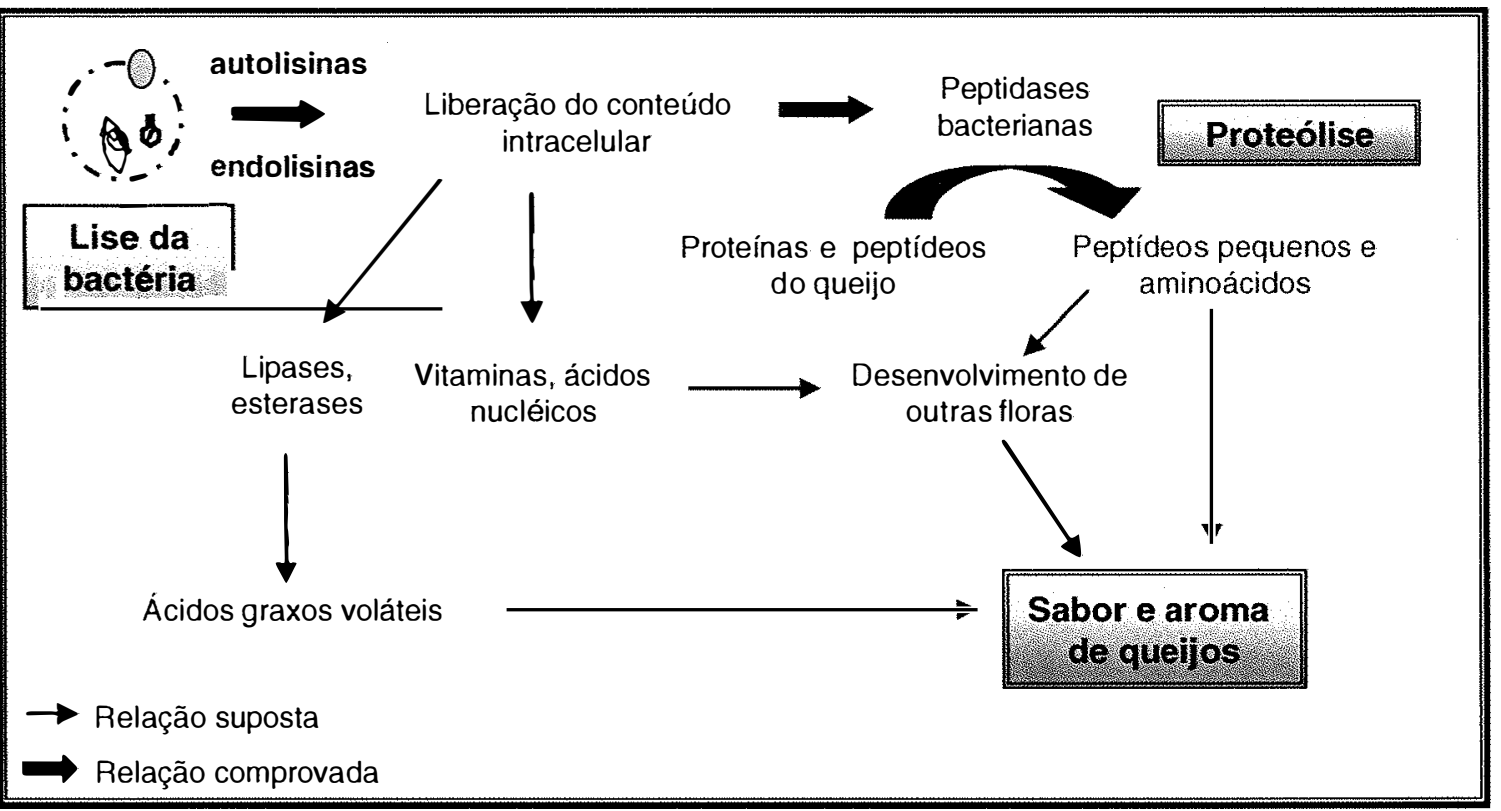

Figura 4 - Esquema ilustrativo do impacto da lise de bactérias durante a maturação de queijos (Adaptado de Derrien, 2001).

Como a autólise de células inteiras é conseqüência de uma reação enzimática, isto é, da hidrólise de ligações de peptideoglicano pelas enzimas líticas (autolisinas ou endolisinas de fagos, as peptideoglicano-hidrolases), sua taxa e extensão dependem de parâmetros físicos e bioquímicos, tais como, $\mathrm{pH}$, temperatura, força iônica, presença de cátions particulares e outros que, como regra geral, influenciam reações enzimáticas. Por ser um fenômeno celular intrínseco, outros dois fatores adicionais podem influenciar a taxa e a extensão da autólise: (1) a característica genética da linhagem e (2) o estado fisiológico da célula. A idade da cultura, bem como seu histórico, ou seja, a ocorrência de vários tipos de estresse durante a sua incubação, como a própria composição e temperatura do meio de cultivo, entre outros, também influenciam a taxa de autólise (Lortal et al., 1997).

\subsubsection{Evidências de autólise in vitro de bactérias de interesse em laticínios}

A autólise é um fenômeno universal no mundo microbiano, não existindo somente entre as bactérias lácticas. Sabendo-se da grande variação com que os 
parâmetros do meio em que as bactérias se encontram podem influenciá-las, é possível estabelecer as condições ótimas ou favoráveis para a ocorrência da autólise de uma determinada espécie in vitro (Lortal et al., 1997). Ela ocorre, notoriamente, quando as condições do meio em que as bactérias encontram-se, tornam-se desfavoráveis; quando há, por exemplo, carência nutritiva, presença de um antibiótico inibindo a síntese do peptideoglicano ou falta de oxigênio a uma bactéria aeróbia. Quando o objetivo é a otimização de parâmetros, a autólise é freqüentemente avaliada por meio do decréscimo da densidade ótica a $650 \mathrm{~nm}\left(\mathrm{DO}_{650}\right)$ ou do aumento em proteínas ou de DNA livre no sobrenadante (Figura 5).
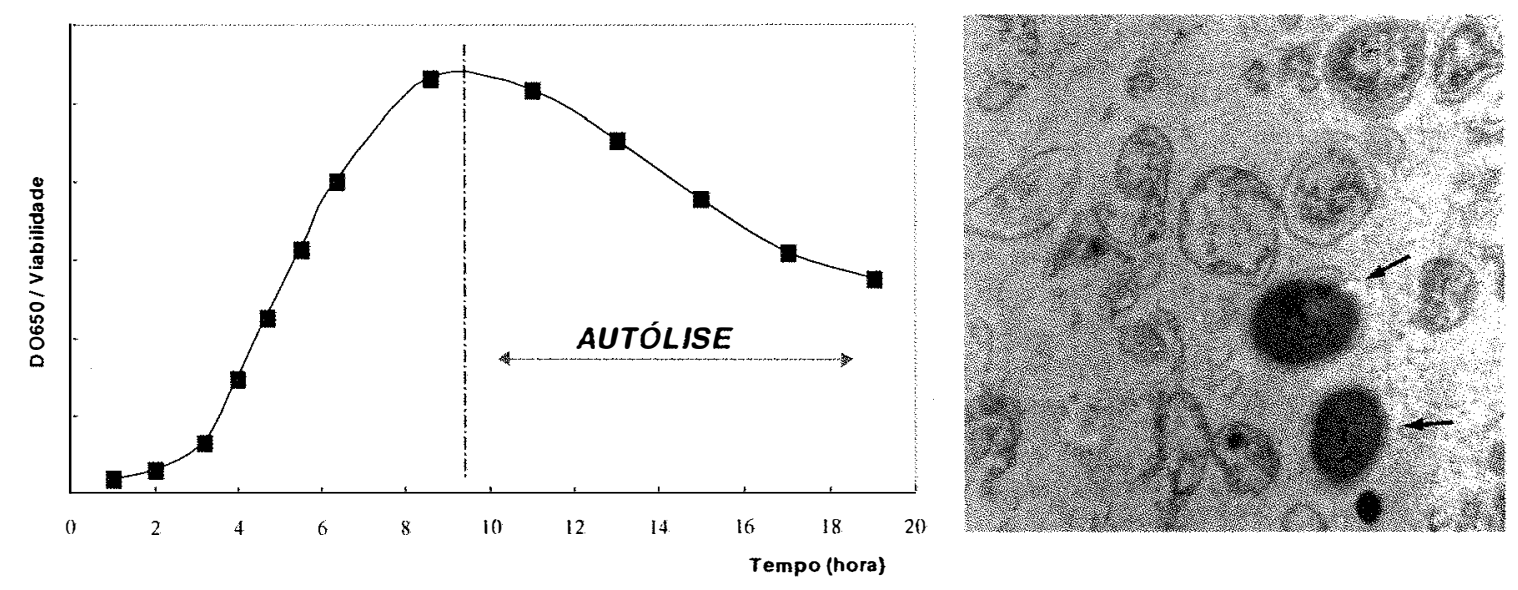

Figura 5 - Curva típica de diminuição da D.O. $650 \mathrm{~nm}$, ilustrando a ocorrência da autólise de bactérias na fase estacionária de crescimento. A fotografia mostra a liberação do conteúdo citoplásmático pelas bactérias e duas células intactas (Cortesia de S. Lortal, INRA, França).

O gênero Lactococcus talvez seja o mais estudado quanto à autólise entre as bactérias lácticas. Várias linhagens de Lactococcus (L. lactis subsp. cremoris ou subsp. lactis ou ainda L. lactis subsp. lactis biovar diacetylactis) já foram estudadas em meio líquido e em solução tampão, avaliando-se a densidade ótica celular a $650 \mathrm{~nm}$ $\left(\mathrm{OD}_{650}\right)$ em espectrofotômetro (Vegarud et al., 1983; Langsrud et al., 1987; Riepe, et al., 1997) ou a liberação de enzimas intracelulares (Langsrud et al., 1987). Esses estudos puderam demonstrar tanto as diferenças entre linhagens, como a influência da 
composição do meio de cultura sobre elas. Particularmente, logo que a lactose é substituída pela glicose, a autólise torna-se mais rápida e alcança uma proporção maior de células, pois suas paredes se tornam mais frágeis osmoticamente e mais susceptíveis à ação das autolisinas.

Algumas condições favoráveis à autólise foram estabelecidas em Lactobacillus acidophilus; a $N$-acetilmuramidase da linhagem 63 AM Gasser tem um pH ótimo entre 5 e 6 quando lisa células intactas ou paredes celulares isoladas. A lise celular a pH 5 é 2 ou 4 vezes mais rápida em tampão citrato $0,01 \mathrm{M}$ e $0,5 \mathrm{M}$ ou mais elevada em tampão citrato 0,1 M (Coyette \& Schockman, 1973). Lortal et al. (1989) estudando $L b$. helveticus constataram uma estimulação da autólise por EDTA, assim como por inibidores da tripsina e da pepsina, sugerindo que, nesse caso, as proteases do lactobacilo têm a capacidade de degradar as enzimas autolíticas e, portanto, de inativálas.

Bactérias propiônicas de interesse em laticínios também já foram estudadas quanto às suas características autolíticas in vitro, devido à sua importância na maturação de queijos do tipo Suíço. Lemée et al. (1994) avaliaram 56 linhagens de Propionibacterium freudenreichii quanto à sua capacidade autolítica espontânea em tampão fosfato $\left(0,1 \mathrm{~mol} / 1, \mathrm{pH} 6,2,37^{\circ} \mathrm{C}\right)$ por meio da densidade ótica a $650 \mathrm{~nm}\left(\mathrm{DO}_{650}\right)$. Em pesquisa subseqüente, Lemée et al. (1995) estudaram 6 linhagens de $P$. freudenreichii, porém em meio de cultura específico, e selecionaram a linhagem CNRZ 725, que apresentou a maior taxa de autólise, para posterior estudo das autolisinas. Com tais trabalhos, esses pesquisadores verificaram que as observações feitas em tampão fosfato, com relação às características autolíticas das linhagens, foram similares àquelas em meio de cultura líquido específico, concluindo que a atividade autolítica de bactérias propiônicas empregadas em laticínios é bastante variável e dependente da linhagem. Através da análise das autolisinas, foi revelado que o sistema autolítico das bactérias propiônicas de interesse em laticínios é bastante complexo.

Em suma, através desses estudos em meio líquido ou em tampão, observou-se que existe grande variação entre as linhagens e também entre as espécies quanto às suas capacidades autolíticas. Segundo Lemée et al. (1995), a aptidão à autólise 
é uma característica própria das linhagens dentro de um determinado ambiente e de acordo com Lortal (1997), essas diferenças podem ser atribuídas ao estado de ativação das autolisinas em uma determinada linhagem e/ou devido à sua parede celular apresentar-se mais frágil.

Portanto, a autólise de bactérias lácticas em meios de cultura está bem caracterizada, mas não está da mesma maneira em condições reais, ou seja, em queijos, pois o comportamento das linhagens não é necessariamente o mesmo nos dois ambientes, em razão da complexidade existente nos queijos e dos numerosos desvios que ocorrem devido aos elementos presentes no leite: células somáticas, células da flora banal e restos de células destruídas pelo tratamento térmico do leite de fabricação.

\subsubsection{Métodos de avaliação da autólise de bactérias lácticas em queijos}

Os estudos referentes à autólise de bactérias lácticas e seu impacto na maturação de queijos intensificaram-se somente nos últimos dez anos, após a demonstração de que as peptidases de Lactococcus lactis localizavam-se exclusivamente no interior da célula. Como essas enzimas possuem um potencial enzimático bastante elevado e, somente após a autólise poderão atuar na matriz do queijo e contribuir no desenvolvimento de sabor, aroma e textura, há um grande interesse em se conhecer os mecanismos que provocam a sua liberação.

A avaliação da autólise de bactérias durante o período de maturação de queijos não é uma tarefa fácil, pois vários problemas de ordem metodológica podem ocorrer, visto que as células bacterianas encontram-se incrustadas em um meio sólido e complexo. Existem três principais métodos para estimar a autólise bacteriana em queijos: 1) microscopia eletrônica; 2) numeração de células viáveis, em meios de cultura específicos e 3) deteç̧ão ou determinação do material intracelular liberado. Cada método apresenta suas vantagens e desvantagens, sendo a melhor forma de avaliação, a combinação de diferentes métodos (Crow et al., 1995).

A partir de um corte interno do queijo, as células danificadas ou autolisadas podem ser visualizadas pela técnica de microscopia eletrônica de 
transmissão ou varredura. Porém, essa técnica é bastante subjetiva, pois não reflete a realidade do interior de todo o queijo. Além disso, os tratamentos aplicados nas amostras são um tanto drásticos e podem induzir a conclusões errôneas. Esta técnica pode ser utilizada apenas de forma qualitativa, em combinação com outros métodos a seguir comentados.

A contagem de células bacterianas no decorrer da maturação de queijos geralmente decresce, em vista da viabilidade celular diminuir. No entanto, não se pode fazer uma correlação simplista de que a queda de viabilidade é uma conseqüência da autólise, já que algumas células podem tornar-se não cultiváveis sem, no entanto, autolisar-se. Já foi observada em queijos, através de microscópio eletrônico por varredura, a presença de cultura láctica na forma de protoplastos ou esferoplastos (Unemoto et al., 1978; Chapot-Chartier et al., 1994). Como células nesse estágio não formam colônias, quando se emprega o procedimento normal de plaqueamento, pode-se observar uma queda de densidade celular sem que haja a liberação esperada de enzimas intracelulares no interior do queijo (Crow et al., 1993; Wilkinson et al., 1995; O’Donovan et al., 1996). Dessa forma, faz-se necessário uma confirmação da autólise através de uma outra técnica.

A deteç̧ão de um constituinte intracelular bacteriano liberado na matriz do queijo é a melhor forma de demonstrar a ocorrência da autólise. O material genético, o DNA ou o RNA, seriam as moléculas ideais como marcadores de autólise. No entanto, alguns autores observaram que tais moléculas são rapidamente degradadas e a taxa de autólise pode ser subestimada. Por outro lado, várias enzimas citoplasmáticas foram utilizadas com sucesso como marcadores de autólise, como as enzimas X-prolildipeptidil (PepX), aminopeptidase (PepC) (Chapot-Chartier et al., 1994), lactato desidrogenase (LDH), glucose-6-fosfato desidrogenase (G6PDH), metil malonil coenzima A mutase (MMCoA) e dipeptidase (PepD) (Valence et al., 1998; Valence et al., 2000), para a determinação do fenômeno de rompimento de células principalmente de Lactococcus, Lactobacillus e Propionibacterium em queijos (Tabela 1).

Como a técnica de Western-Blot, associada às técnicas imunológicas para a revelação de enzimas marcadoras, foi utilizada como uma ferramenta fundamental 
nesse trabalho, para o estudo da lise de Lactococcus sp., toda a sua descrição metodológica está apresentada no Anexo B.

\subsubsection{Evidência de autólise de bactérias lácticas em queijos}

Os primeiros pesquisadores a demonstrarem a autólise de Lactococcus em queijo Cheddar foram Law et al. em 1974, usando uma dipeptidase intracelular como marcador enzimático. Foi, também, claramente demonstrada nesse mesmo tipo de queijo por Wilkinson et al. (1994) e Crow et al. (1995). Wilkinson et al. (1994) observaram, no entanto, que a intensidade da autólise varia segundo a linhagem de Lactococcus empregada na fabricação do queijo. Constatou-se, assim, que a taxa mais elevada da proteólise secundária ocorreu no queijo fabricado com a linhagem mais autolítica, relacionando-se este fato com a liberação de peptidases dos lactococos pela ocasião da lise. Estes resultados foram confirmados por O'Donovan et al. (1996) avaliando a taxa de autólise de três linhagens de L. lactis subsp. cremoris em queijo Cheddar. Eles observaram um comportamento distinto entre as linhagens estudadas; a taxa de liberação de enzimas através de marcador enzimático não ocorreu no mesmo sentido que a análise da viabilidade celular, indicando que a contagem de células não é a técnica mais adequada para avaliação de autólise.

A autólise de Lactococcus também foi demonstrada em queijo Saint Paulin por Chapot-Chartier et al. (1994). Esses autores estudaram a autólise de duas linhagens de Lactococcus (L. lactis subsp. cremoris AM2 e L. lactis subsp. lactis NCDO763) durante a maturação desse queijo, avaliando (1) a liberação de duas peptidases intracelulares: X-prolil dipeptidil aminopeptidase e uma aminopeptidase de ampla especificidade; (2) a contagem de células viáveis e (3) as mudanças morfológicas através de microscopia eletrônica por transmissão. As duas linhagens apresentaram comportamento totalmente distinto durante a maturação. A linhagem AM2 apresentou uma queda de viabilidade na primeira semana após a fabricação, estando correlacionada com a lise de células, o que pôde ser comprovado através da visualização em microscópio eletrônico ( 80 \% das bactérias estavam destituídas de parede celular), além 
do maior acúmulo das duas peptidases testadas no extrato do queijo. Com relação à linhagem NCDO763, esta permaneceu intacta no interior do queijo, segundo análise por microscopia eletrônica; as enzimas testadas não foram detectadas no interior do queijo nas três primeiras semanas de maturação e a queda de viabilidade celular foi muito pequena, somente de $10 \%$ durante as 8 semanas de maturação. Através desses dados, foi possível correlacionar a elevada suscetibilidade da linhagem AM2 em lisar-se com o maior acúmulo de aminoácidos livres e com a diminuição de sabor amargo no queijo correspondente. Com esse estudo, evidenciaram-se diferenças nas propriedades autolíticas num mesmo gênero de bactérias lácticas.

Tabela 1. Atividade de enzimas intracelulares de espécies bacterianas detectadas em diversos tipos de queijos, indicando a ocorrência de autólise.

\begin{tabular}{|c|c|c|c|}
\hline $\begin{array}{c}\text { Queijo } \\
\text { estudado }\end{array}$ & $\begin{array}{l}\text { Gênero ou espécie } \\
\text { em estudo }\end{array}$ & $\begin{array}{l}\text { Atividade } \\
\text { detectada* }\end{array}$ & Autores \\
\hline Cheddar & Lactococcus sp. & Dipeptidase & Law et al., 1974 \\
\hline Cheddar & Lactococcus sp. & $\begin{array}{l}\text { LDH, G6PDH, } \\
\text { PepX }\end{array}$ & Wilkinson et al., 1994 \\
\hline Saint Paulin & Lactococcus sp. & PepX, PepC & $\begin{array}{l}\text { Chapot-Chartier et al., } \\
1994\end{array}$ \\
\hline Cheddar & Lactococcus sp. & $\begin{array}{l}\text { Aminopeptidase, } \\
\text { FBP-aldolase }\end{array}$ & Crow et al., 1995 \\
\hline Emmental & $\begin{array}{l}\text { Lactobacillus } \\
\text { helveticus }\end{array}$ & Dipeptidase PepD & Valence et al., 1998 \\
\hline Emmental & $\begin{array}{l}\text { Propionibacterium } \\
\text { freudenreichii }\end{array}$ & MMCoA mutase & Valence et al., 2000 \\
\hline
\end{tabular}

* Atividade detectada no extrato aquoso de queijo

Kawabata et al. (1997), avaliando a autólise de L. lactis durante a maturação do queijo Saint Paulin, verifïcaram a ocorrência de uma contaminação acidental de fagos durante uma de suas fabricações, com conseqüente produção sete vezes superior de aminoácidos nesses queijos, quando comparados aos queijos-não contaminados. Supuseram, dessa forma, que a presença de um profago indutor em certas linhagens de Lactococcus implicaria numa lise maior do que em bactérias livres de fagos. Para comprovar essa hipótese, induziram a cura de um profago da mesma 
linhagem lisogênica anteriormente utilizada (Lepeuple et al., 1997) e avaliaram a sua capacidade residual de lise no interior do queijo Saint Paulin. Observaram uma fraca taxa de autólise dessa linhagem curada de L. lactis e o queijo apresentava menor concentração de aminoácidos livres e sabor amargo mais intenso.

Outras bactérias como lactobacilos e propionibactérias também já foram estudas quanto à autólise natural em queijos, porém com menos intensidade que o gênero Lactococcus. Valence et al. (1998), por exemplo, demonstraram a autólise de lactobacilos termófilos e de bactérias propiônicas em queijos do tipo Suíço. Fabricaram o Emmental com leite microfiltrado e inoculado com as linhagens: Lb. helveticus ITGLH77 e P. freudenreichii ITGP23. A autólise foi avaliada através da viabilidade celular, microscopia eletrônica por varredura e detecção das enzimas específicas intracelulares por Immunoblotting: dipeptidase (PepD) para Lb. helveticus e metil malonil coenzima A mutase (MMCoA) para $P$. freudenreichii. Quanto à viabilidade celular, $L b$. helveticus exibiu maior queda $(99,9 \%)$ a partir do início da maturação em câmara quente; ao mesmo tempo, PepD foi encontrada nos extratos aquosos dos queijos e detectada até o final da maturação. Verificou-se, através de microscopia eletrônica por varredura, que as células de $L b$. helveticus estavam danificadas, demonstrando-se claramente a autólise dessa espécie em queijo do tipo Suíço (Emmental). Por outro lado, a linhagem $P$. freudenreichii, multiplicou-se durante o período em que permaneceu na câmara quente e não foi detectada perda de viabilidade, após o período máximo de crescimento ( $10^{9} \mathrm{ufc} / \mathrm{g}$ queijo). A enzima MMCoA foi detectada somente ao final da maturação, durante a estocagem a frio, quando os extratos aquosos foram concentrados 20 vezes, demonstrando que a autólise dessa bactéria foi tardia e limitada.

Nesse mesmo trabalho, Valence et al. (1998) também estudaram a presença de marcadores de lise (PepD) nos queijos comerciais Emmental, Beaufort, Comté e Parmesão, através da técnica de Immunoblotting, para avaliar a autólise de Lactobacillus. Nos queijos Comté e Parmesão, a enzima PepD foi claramente detectada, mostrando a ocorrência da autólise de Lb. helveticus. Já no caso dos queijos Beaufort e Emmental, somente sinais fracos de uma PepD com peso molecular um pouco menor que aquela de $L b$. helveticus foram detectados. Essa banda resultante de reação cruzada 
foi identificada como uma proteína de $51 \mathrm{kDa}$ detectada no citoplasma bruto de $L b$. lactis, indicando a autólise dessa espécie nesses queijos.

A autólise de outros microrganismos empregados em tecnologia queijeira, tais como alguns lactobacilos, estreptococos termófilos, leuconostoc, Kluveromyces e Geotrichum, foi igualmente demonstrada por Valence (1999) em queijos do mercado francês, através de marcadores imunológicos de lise.

Do ponto de vista tecnológico, os resultados dos autores supra citados são todos coerentes e podem ser assim resumidos: (1) a autólise permite a liberação de peptidases que permanecem ativas (no mínimo algumas delas) por várias semanas no interior do queijo; (2) há uma correlação evidente entre a extensão da autólise e a quantidade final de peptídeos de tamanho pequeno e de aminoácidos livres, que pode ser aumentada em até seis vezes; (3) a autólise em queijos não pode ser somente avaliada tomando-se resultados de contagem de células; (4) quando há análise sensorial envolvida, há uma clara redução do sabor amargo relacionada à autólise do fermento láctico.

Concluindo, a autólise de bactérias é um fenômeno freqüente e essencial para a maturação de queijos e já foi observada em diversas espécies bacterianas e em vários tipos de queijos. Sua extensão é altamente dependente da linhagem e das condições de fabricação envolvidas. Os mecanismos que regulam a autólise não são ainda totalmente compreendidos, mas é importante saber como controlá-los em virtude de sua importância para a formação de produtos da proteólise. Contudo, a característica de uma linhagem bacteriana à autolisar-se no interior de um queijo, já se tornou um critério adicional de seleção. 


\subsection{MaturaÇão de QueiJos: Proteólise e ACELERaÇão}

A maturação de queijos é um processo complexo que envolve uma série de mudanças bioquímicas, onde uma coalhada sem sabor ou aroma particulares é transformada num queijo com características de flavour e textura típicos de uma dada variedade. As principais vias bioquímicas que ocorrem durante a maturação, incluem a degradação das proteínas do leite a pequenos peptídeos e aminoácidos através da proteólise e subseqüentemente ocorrem reações do catabolismo de aminoácidos; os ésteres de ácidos graxos são convertidos em ácidos graxos livres pela lipólise e, através da glicólise, a lactose é convertida em ácido láctico, como ilustra a Figura 6. Todo esse processo pode variar desde semanas até anos, dependendo do tipo de queijo que se deseja obter (Fox, 1989; El Soda \& Pandian, 1991; Wilkinson, 1993).

\subsubsection{A proteólise durante a maturação de queijos}

A proteólise é, provavelmente, a mais importante transformação bioquímica durante a maturação para a maioria das variedades de queijo, com um maior impacto sobre o sabor, aroma e textura (Fox, 1989; El Soda \& Pandian, 1991; Visser, 1993; Law \& Haandrikman, 1997). Ela pode ser dividida em três fases: 1) proteólise no leite, antes da fabricação do queijo; 2) durante a coagulação enzimática do leite e 3) durante a maturação do queijo (Fox, 1989; Fox et al., 1994).

Várias categorias de enzimas proteolíticas estão envolvidas na maturação de queijos, atuando conjuntamente. Quatro e, possivelmente, cinco agentes estão envolvidos: 1) proteases naturais do leite (plasmina); 2) coagulante adicionado no momento da coagulação (ex: quimosina, pepsina ou proteases microbianas); 3) enzimas da flora banal do leite, que sobrevive à pasteurização; 4) fermento láctico adicionado e suas enzimas; 5) as enzimas da flora láctica secundária (exemplos: 
(a) CASEÍNAS

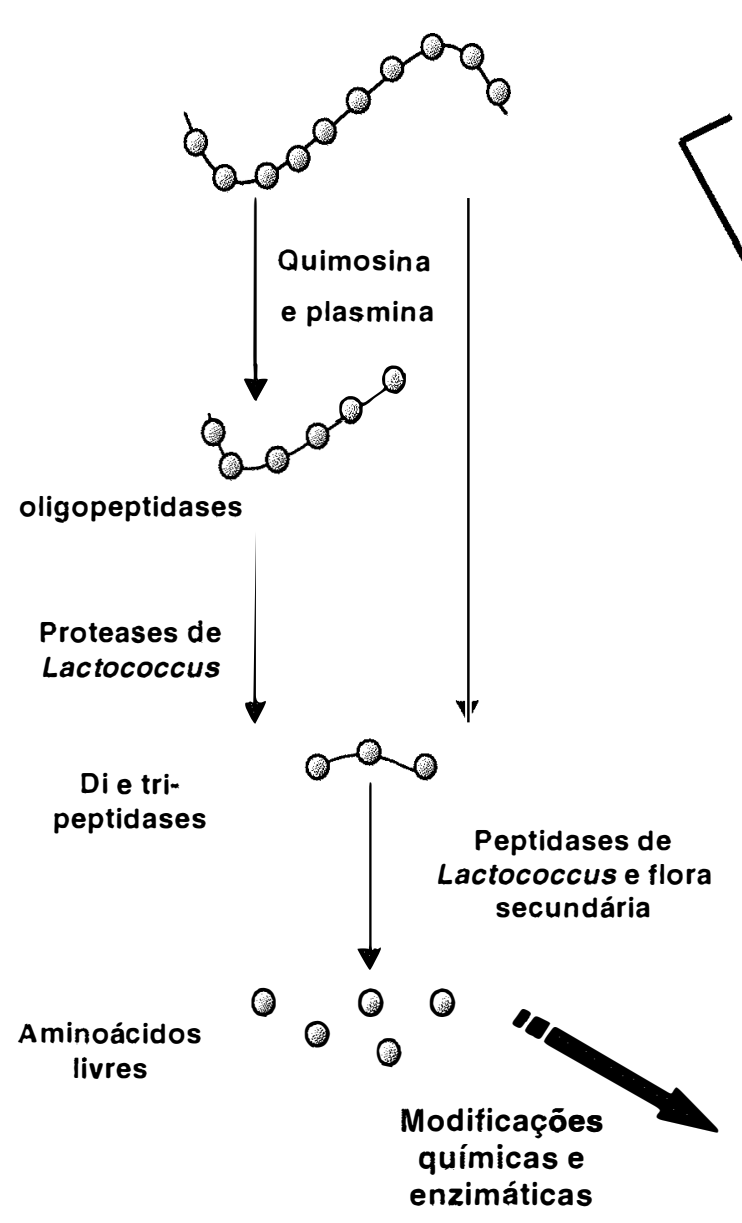

(b) TRIGLICERÍDEO
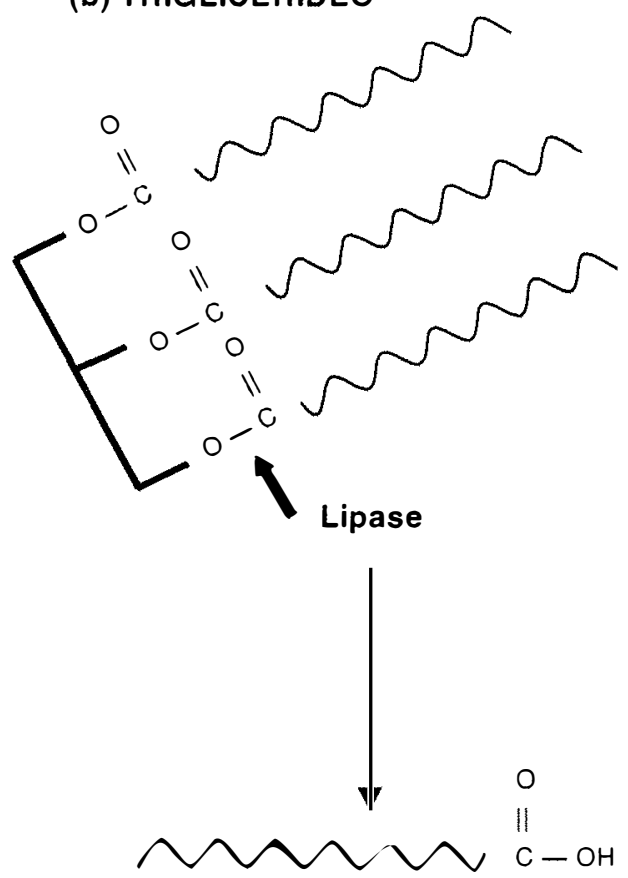

Ácido graxo livre

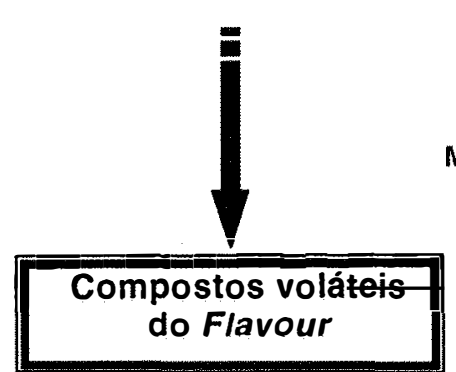

(c) LACTOSE

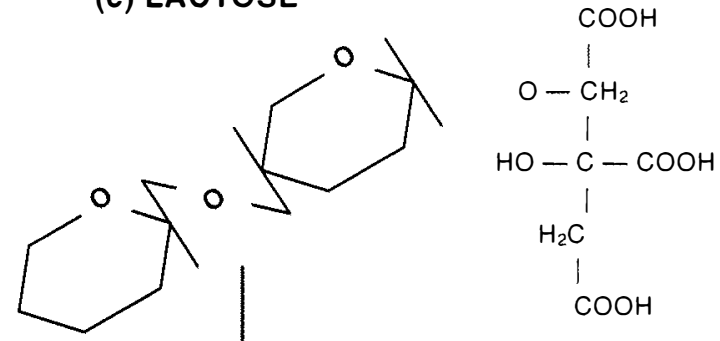

Fermentação por Lactococcus
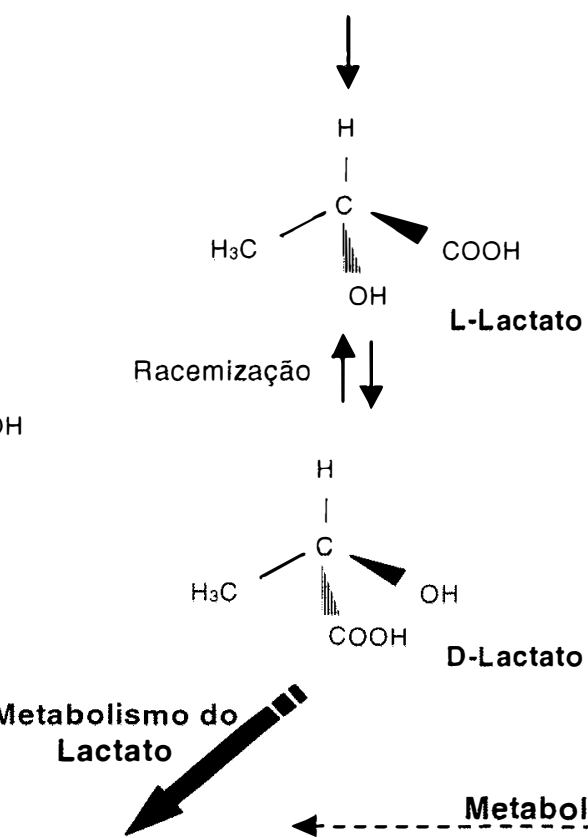

D-Lactato

Metabolismo

do Citrato

Figura 6 - Principais vias bioquímicas da maturação: (a) proteólise; (b) lipólise; (c) metabolismo da lactose e do citrato (Adaptado de McSweeney \& Sousa, 2000). 
propionibactérias, Brevibacterium linens; leveduras e fungos, tais como Penicillium roquefort e P. camembert (Law, 1987; Fox, 1988; Choisy et al., 1997).

Para o desenvolvimento de um queijo com sabor, aroma e textura característicos, é necessário que a degradação das proteínas (caseínas), por enzimas proteolíticas, em peptídeos de cadeia curta e em aminoácidos, ocorra de forma adequada. Desvios durante esse delicado processo, implicarão em mudanças na textura, no sabor e no aroma, descaracterizando o produto desejado (Visser, 1993). A extensão e a natureza da proteólise durante a maturação, assim como a origem e a quantidade dos produtos formados, variam de acordo com as enzimas disponíveis envolvidas e com as condições ambientais de maturação (Grappin et al., 1985).

\subsubsection{Proteases do leite, da flora nativa e do coagulante}

A principal protease endógena do leite é a plasmina (EC 3.4.217), uma serina-protease, com pH ótimo de 7,5 e elevada especificidade para as ligações peptídicas envolvendo resíduos de lisina. O leite provavelmente possui todo o sistema da plasmina: a enzima plasmina, o plasminogênio, os inibidores da plasmina, os ativadores do plasminogênio e inibidores dos ativadores do plasminogênio. A maioria (85-90\%) da plasmina do leite bovino existe na forma de plasminogênio, que pode ser ativado pela uroquinase e por ativadores endógenos. No leite, a plasmina e o plasminogênio estão associados às micelas de caseína e as acompanham na massa do queijo, enquanto os outros componentes do sistema da plasmina estão na fase sérica e são removidos no soro de fabricação de queijos tradicionais (Fox \& Law, 1991; Fox \& Stepaniak, 1993). As proteases de células somáticas e de enzimas secretadas pela flora nativa do leite, principalmente as proteases termo-resitentes de psicrófilos, estão também presentes no leite (Law, 1987; Law et al., 1992). Essas enzimas têm um papel muito limitado durante a maturação, pois são, em sua maioria, inativadas pela pasteurização. No entanto, quando se utiliza leite cru para fabricar queijos, como os de apelação de origem controlada (AOC) em países como a França, todas essas enzimas continuam ativas e contribuem para a proteólise, sendo as enzimas da flora nativa as de maior importância 
para o desenvolvimento do sabor e aroma típicos desses queijos, como já foi claramente demonstrado por McSweeney et al. (1993).

A quimosina e a pepsina são as principais proteases tradicionalmente encontradas em coalhos usados na fabricação de queijos. A principal função das enzimas coagulantes é iniciar a coagulação (do leite) através da hidrólise específica da $\kappa$-caseína, nas ligações Phe ${ }_{105}-\mathrm{Met}_{106}$, formando a rede de paracaseinato de cálcio. Durante a coagulação, somente uma pequena parte dessas enzimas é retida na coalhada (cerca de $6 \%$ ), que contribuirá para os estágios iniciais da maturação do queijo através da

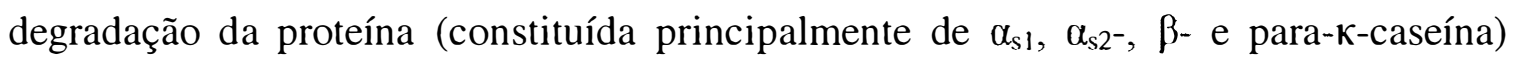
(Fox, 1988; Walstra, 1990).

Em suma, a proteólise primária na maioria dos queijos é feita pelas enzimas residuais do coagulante e com menos expressão pela plasmina, resultando na formação de peptídeos de médio e grande tamanho. Esses peptídeos serão ainda degradados pelas enzimas do fermento láctico e pelas enzimas de microrganismos da flora secundária (Engels, 1997), comentados a seguir.

\subsubsection{Enzimas proteolíticas do fermento láctico}

A maioria das culturas componentes dos fermentos lácticos usados na fabricação de queijos é pertencente aos gêneros Lactococcus e Lactobacillus, que contam com um sistema complexo de enzimas proteolíticas para a provisão de aminoácidos de seu meio de crescimento, já que suas capacidades biosintéticas são limitadas (Monnet et al., 1993; Benthin \& Villadsen, 1996). Nesta revisão, somente serão consideradas as enzimas proteolíticas de bactérias mesofílicas de lactococos, aquelas utilizadas na fabricação dos queijos Saint Paulin e Minas Frescal.

Embora o gênero Lactococcus seja considerado pouco proteolítico quando comparado a outros gêneros de bactérias como Bacillus, Proteus, Pseudomonas, Brevibacterium, possui um sistema proteolítico altamente rico, com enzimas capazes de hidrolizar completamente peptídeos derivados da caseína a aminoácidos (Figura 7) (Chapman \& Sharpe, 1990; Monnet et al., 1993). Esse sistema é constituído por uma protease ligada à parede celular e por várias peptidases intracelulares: três 
aminopeptidases, uma dipeptidase, uma tripeptidase, uma X-prolil dipeptidil aminopeptidase, uma prolidase e no mínimo três endopeptidases (Monnet et al, 1993).

Somente a enzima protease em lactococos é de fato extracelular e, encontrando-se associada à parede celular, possui um rápido acesso às proteínas extracelulares (Fox et al., 1994), tendo como substrato maior a $\beta$-caseína. Os genes dessa proteína estão localizados em um plasmídeo (Monnet et al., 1993). No entanto, essa enzima não possui um papel significativo na proteólise, visto os resultados obtidos por Oberg et al. (1986), quando utilizaram um mutante Prt - em queijos Cheddar e compararam com queijos fabricados com fermentos normais $\mathrm{Prt}^{+}$, em que as concentrações de $\mathrm{N}$ solúvel ( $\mathrm{pH}$ 4,6) aumentaram de forma similares em ambos os queijos. Segundo Fox et al. (1994), essa enzima pode conduzir à formação de sabor amargo em alguns queijos, pela liberação de peptídeos de cadeia curta apolares (hidrofóbicos) ricos em prolina. Como esses peptídeos são muito longos para poderem atravessar a membrana plasmática, existem as peptidases para completar tal hidrólise.

Quanto às peptidases de lactococos, somente no início da década de 90 foi estabelecido que sua localização é intracelular e que seus genes são de origem cromossômica (Monnet et al., 1993; Tan et al., 1992). Existem 3 categorias de peptidases: 1) as aminopeptidases, com especificidade de corte no lado $\mathrm{N}$-terminal, sendo elas: Pep N (uma metaloenzima, com larga especificidade), PepC (uma enzimacisteína, com larga especificidade), PepA (metaloenzimas termoestáveis, com especificidade aos aminoácidos ácidos Asp e Glu na posição N-terminal); 2) as dipeptidases e tripeptidases, sendo todas metaloenzimas: DIP I, DIP II, DIP III, TRP I, TRIP II, peptidases específicas da prolina (X-prolil dipeptidil aminopeptidase), PepX, prolidases PRD I e PRD II, prolina iminopeptidase PIP; 3) as endopeptidases, metaloenzimas de larga especificidade: LEP I, LEP II, LEP III (Monnet et al., 1993). Como essas enzimas estão em sua maioria presentes em lactococos e são responsáveis pela proteólise final nos queijos, atribui-se, atualmente, uma grande importância ao caráter autolítico da linhagem, já que as peptidases não se difundem passivamente através das membranas intactas. É através da lise de bactérias que as peptidases serão liberadas com mais ou menos rapidez na massa do queijo, dependendo da linhagem. Se a 
lise ocorre rapidamente, as enzimas atuarão com maior intensidade sobre as caseínas, liberando maiores quantidades de peptídeos e de aminoácidos (Figura 7) (Wilkinson et al., 1994; Crow et al., 1995; item 2.3).

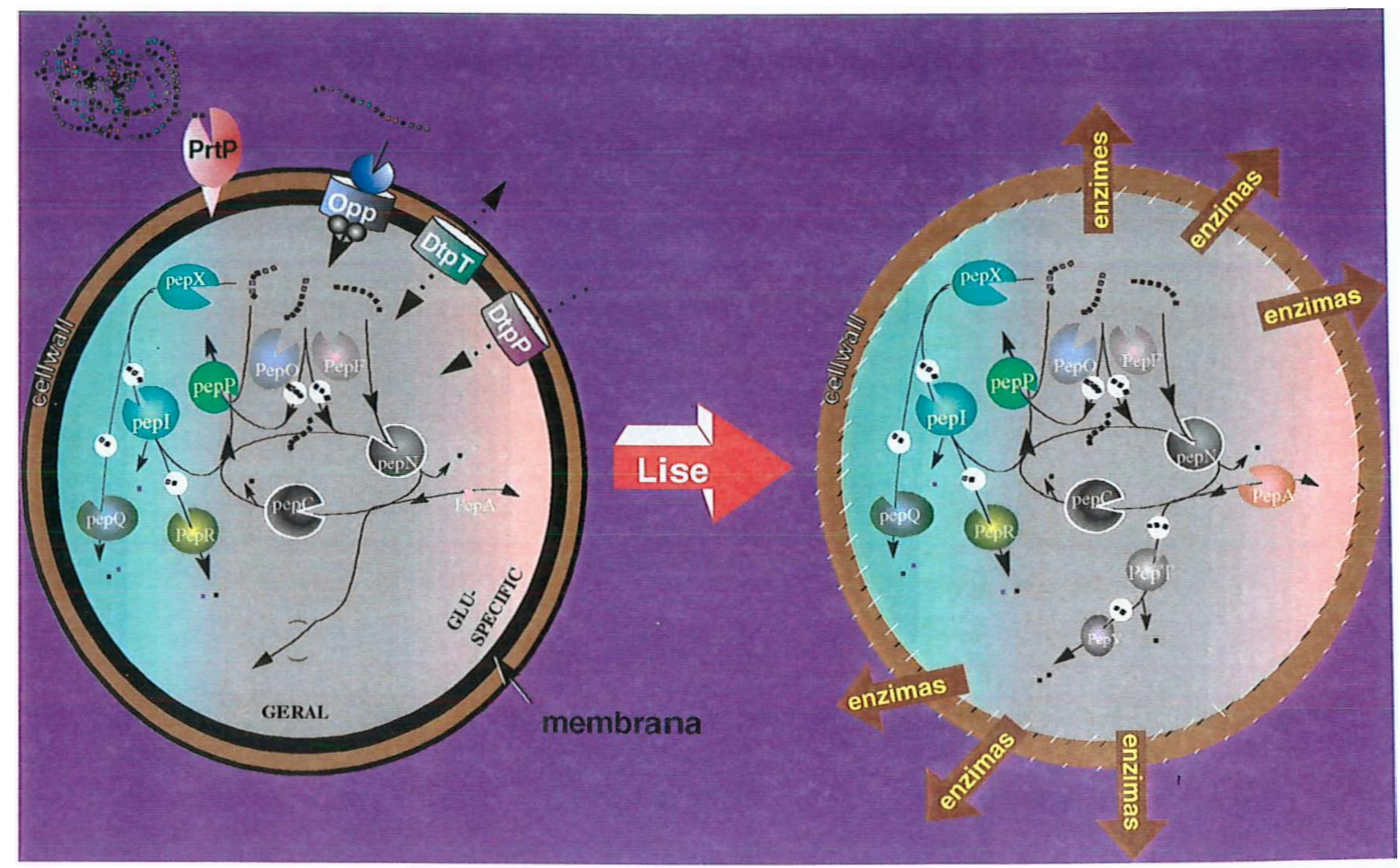

Figura 7 - Sistema proteolítico de Lactococcus (Cortesia N. Sørensen, Chr. Hansen, Dinamarca).

Assim, a importância das enzimas proteolíticas de lactococos para a maturação de queijos é óbvia. Com exceção da protease ligada à parede, que é responsável somente pelos estágios iniciais da degradação da caseína, todas, ou no mínimo algumas das peptidases de lactococos, possuem uma função essencial na proteólise (Bockelmann, 1995). Os peptídeos produzidos durante a proteólise primária, são posteriormente hidrolisados pelas peptidases de lactococos em aminoácidos livres, que são os precursores dos compostos de aroma (Choisy et al., 1997). 


\subsubsection{Enzimas de microrganismos da flora secundária}

Certas variedades de queijos são caracterizadas pelo crescimento de microrganismos secundários durante a maturação, como Propionibacterium freudenreichii em queijos do tipo Suíço, Penicillium spp. em queijos maturados por fungos como o Camembert e Roquefort e Brevibacterium linens em queijos com superfície limbosa. Essas floras secundárias, principalmente os fungos e microrganismos que se desenvolvem na superfície de queijos maturados, produzem enzimas proteolíticas ativas, influenciando a proteólise em todos os estágios da maturação, ou seja, desde a hidrólise inicial da caseína até a produção de aminoácidos livres (McSweeney \& Fox, 1997b).

As bactérias propiônicas de interesse para a indústria de laticínios são organismos gram-positivos e possuem uma função importante na maturação de queijos Suíços (Gautier et al., 1993; Lemeé et al., 1994), particularmente no desenvolvimento de compostos voláteis que contribuem para o flavour, como os ácidos acético e propiônico e o aminoácido prolina e, da formação de olhaduras. Essas bactérias são também importantes na tecnologia de fabricação de queijos com textura fechada como o Appenzel e o Tilsit (Steffen et al., 1993).

\subsubsection{Avaliação da proteólise durante a maturação de queijos}

A deteç̧ão e quantificação de produtos da hidrólise de proteínas, formados durante a maturação dos queijos, são usadas como índices de proteólise, uma vez que a mesma está associada ao desenvolvimento de sabor, aroma e textura típicos da grande maioria dos queijos. Os métodos mais comumente utilizados para a separação de proteínas intactas dos peptídeos e aminoácidos formados pela proteólise baseiam-se, principalmente, na precipitação fracionada (com ácidos ou solventes), mas métodos de eletroforese e cromatografia também são bastante empregados (Law, 1987; Fox et al., 1994). 
Para monitorar a proteólise durante a maturação ou conservação de queijos, pode-se mensurar as formas de nitrogênio existentes no queijo, ou seja, o nitrogênio total (NT), o nitrogênio não-caseínico (NCN) e o nitrogênio-não-protéico (NPN) e avaliar a cinética de sua degradação e formação. Segundo Choisy et al. (1997), o termo NCN é geralmente usado para a fração de nitrogênio correspondente aos produtos que não são precipitados a pH 4,6 e o NPN é atribuído à fração que é solúvel em ácido tricloroacético, especificamente a uma concentração final de $12 \%$.

A formação do nitrogênio solúvel em pH 4,6 se deve, principalmente, à ação do coalho residual, especificamente sobre a $\alpha_{s 1}$-caseína e em menor escala, sobre a $\beta$-caseína, originando peptídeos de elevado peso molecular. Por outro lado, o nitrogênionão-protéico é proveniente da ação de peptidases dos microrganismos presentes sobre os peptídeos formados (Choisy et al., 1997).

Relacionando o nitrogênio solúvel em pH 4,6 e o nitrogênio não-protéico com o nitrogênio total, obtemos índices conhecidos como extensão e profundidade da proteólise, respectivamente (Wolfschoon-Pombo, 1983). A extensão da proteólise caracteriza-se pela quantidade de substâncias nitrogenadas solúveis acumuladas durante o processo, expressas como porcentagens do nitrogênio total. Sua determinação analítica é baseada na precipitação da caseína até seu ponto isoelétrico $(\mathrm{pH} 4,6)$. Assim, quando uma solução de queijo é trazida a pH 4,6, as caseínas intactas e também aquelas que se degradaram levemente, são precipitadas. Peptídeos de alto peso molecular, peptídeos de cadeia curta e aminoácidos são encontrados nessa solução. Se for adicionado ácido tricloroacético a uma concentração final de $12 \%$ ao sobrenadante obtido após precipitação a pH 4,6, mais peptídeos serão precipitados e somente peptídeos de cadeia curta e aminoácidos permanecerão na solução. Assim, a profundidade da proteólise abrange as substâncias nitrogenadas de baixo peso molecular, acumuladas durante o processo. Os peptídeos e aminoácidos das diferentes frações são geralmente quantificados após degradação do nitrogênio orgânico pela técnica de Kjeldhl (Gripon et al., 1975; Wolfschoon-Pombo, 1983; Choisy et al., 1997).

A eletroforese é provavelmente a técnica mais utilizada para a avaliação da proteólise primária em queijos, principalmente aquela em gel de poliacrilamida 
(PAGE). Como somente as proteínas e os peptídeos de maior tamanho podem ser visualizados pelos procedimentos de coloração, a técnica é limitada ao monitoramento da hidrólise das caseínas e de seus principais produtos formados. É considerada uma ferramenta analítica importante para o acompanhamento da hidrólise de ligações individuais nas moléculas de caseínas, durante as etapas iniciais da maturação de queijos (Fox, 1989; Creamer, 1991).

Atualmente, 2 meios desnaturantes são utilizados em eletroforese: uréia e SDS (dodecil sulfato de sodio). A uréia (4 a $8 \mathrm{M}$ ) promove a dissociação de ligações hidrogenadas e hidrofóbicas, não afeta as cargas intrínsecas das moléculas e a separação ocorre em função da carga e do tamanho, devendo estar presente no tampão e no gel para manter o estado desnaturante. Já o SDS, é um detergente aniônico que se fixa sobre as proteínas $\left(1,4 \mathrm{~g} / \mathrm{g}\right.$ de proteína globular); aquecendo-o a $100^{\circ} \mathrm{C}$ por alguns minutos, todas as moléculas são desnaturadas e carregadas negativamente, ficando com a mesma carga líquida (mesma densidade de carga). Nesse caso, a migração dá-se principalmente em função do tamanho das moléculas, sendo que a distância de migração é proporcional à massa molecular. Por ser uma relação linear, é possível determinar os pesos moleculares visíveis na presença de marcadores (Vincent, 1987).

Alguns pesquisadores (Shalabi \& Fox, 1987) consideram a eletroforese em gel de poliacrilamida contendo uréia como superior àquela contendo SDS para a análise da proteólise de queijos, pois a primeira oferece melhor resolução para peptídeos de pequeno tamanho. No entanto, Strange et al. (1992) consideram que o sistema SDSPAGE fornece informações muito úteis sobre os pesos moleculares dos produtos de degradação das caseínas, principalmente quando completadas pela análise densitométrica. No entanto, a análise em eletroforese, muitas vezes é insuficiente para mostrar diferenças substanciais em diversos tratamentos de queijos. Sempre deve estar associada a outros métodos de avaliação, como a quantificação das formas de nitrogênio, através da precipitação fracionada ou métodos cromatográficos.

A cromatografia de troca iônica feita em analisadores automáticos de aminoácidos, em substituição à cromatografia de troca iônica clássica, tem sido usada para quantificar os aminoácidos livres em queijos. É uma forma de avaliação da 
proteólise secundária e considerada uma técnica relativamente simples, precisa e quantitativa, onde o preparo da amostra é simples. O procedimento atualmente mais utilizado no preparo das amostras para a análise de aminoácidos, inclui a desproteinização do extrato de queijo com o ácido sulfosalić́lico (Mondino et al., 1972).

A hidrólise da caseína pela ação combinada de proteases e peptidases no queijo, leva à liberação de aminoácidos livres, que são considerados importantes na formação de compostos de sabor e aroma em muitos queijos. Suas concentrações variam enormemente de acordo com a variedade de queijo. Além disso, os compostos voláteis formados a partir dos aminoácidos por descarboxilação, desaminação, transaminação ou por outras transformações, possuem uma contribuição substancial na formação dos compostos aromáticos (Wallace \& Fox, 1997). A quantidade total e a composição da mistura de aminoácidos formados têm sido usadas como um índice de maturação de queijos, que em alguns casos, é possível correlacioná-las com o desenvolvimento de compostos que compõem o aroma dos queijos.

\subsubsection{Formação de flavour a partir de produtos da proteólise}

A formação do flavour (sabor e aroma) ocorre essencialmente durante a maturação do queijo. É um processo complexo, onde os vários compostos envolvidos na formação do aroma dos queijos são derivados de três principais vias metabólitas: catabolismo da lactose, catabolismo de lipídeos e catabolismo de proteínas (Yvon \& Rijnen, 2001). Os ativadores dessas vias são as enzimas endógenas do leite, as enzimas coagulantes e principalmente as enzimas do fermento láctico e de outros microrganismos envolvidos na maturação dos queijos (Marchisio et al., 1999).

O sabor e aroma de um queijo maturado é o resultado de um equilíbrio sutil e frágil entre todos os numerosos compostos que eles contêm (Marchisio et al., 1999). Na verdade, o fermento láctico, o método de fabricação do queijo e a flora secundária irão determinar a variedade de um queijo (McSweeney et al., 1997a). Os compostos não-voláteis do flavour como o ácido láctico, $\mathrm{NaCl}$, aminoácidos, peptídeos e ácidos graxos de cadeia longa são os responsáveis pelo sabor do queijo. Já os compostos 
voláteis que promovem a composição do aroma em queijos, incluem os compostos sulfúricos $\left[\mathrm{H}_{2} \mathrm{~S}, \mathrm{CS}_{2}, \mathrm{COS}, \mathrm{CH}_{3} \mathrm{SH}, \mathrm{H}_{2} \mathrm{C}-\mathrm{S}-\mathrm{CH}_{3}\right.$ (dimetil sulfido), $\mathrm{H}_{2} \mathrm{C}-\mathrm{S}-\mathrm{S}-\mathrm{CH}_{3}$ (dimetil disulfido, DMDS)], os ácidos graxos e seus produtos de degradação (lactonas, metil cetonas e álcoois) (Mc Seewney \& Fox, 1997b). No entanto, muito pouco é conhecido sobre quais compostos determinam a qualidade organoléptica de um queijo (Marchisio et al., 1999). Atualmente, vários trabalhos têm sido conduzidos com o intuito de isolar compostos formados em vários tipos de queijos maturados e compará-los (Engels, 1997; Thierry \& Maillard, 2002).

A proteólise, até pouco tempo, era considerada um fator limitante da maturação de muitas variedades de queijos, principalmente em queijos semi-duros, daí o porquê da maioria das pesquisas serem focadas em aceleração da proteólise. No entanto, resultados mais recentes mostram que o aumento da liberação de aminoácidos livres pela intensificação da degradação de peptídeos por bactérias do fermento láctico ou pela adição de aminoácidos livres, não implicam no aumento da formação de aromas em queijos (Christensen et al., 1995; Wallace \& Fox, 1997), sugerindo que o fator limitante não é a liberação de aminoácidos livres, mas sim a conversão de aminoácido em compostos de aroma (Figura 8) (Hemme et al., 1982; Yvon \& Rijnen, 2001).

Diferentes bactérias do fermento láctico e outros microrganismos relacionados à maturação de queijos estão sendo avaliados quanto às suas capacidades em degradar aminoácidos a compostos aromáticos. Para tanto, células ou extratos celulares são incubados em queijos modelos ou em meios sintéticos contendo caseína ou aminoácidos livres e os produtos formados são analisados por CG-MS ou por HPLC (Yvon \& Rijnen, 2001; Klein et al., 2001).

Muitos microrganismos relacionados com a maturação de queijos, incluindo as bactérias do fermento láctico, bactéria corineforme, leveduras e o fungo Geotrichum candidum são capazes de produzir compostos aromáticos a partir de aminoácidos, mas as suas habilidades são altamente dependentes da linhagem em questão (Yvon \& Rijnen, 2001). Assim, o conhecimento das vias catabólicas de aminoácidos e enzimas, que possuem um papel chave na formação de aromas, pode 
possibilitar o desenvolvimento de testes rápidos para a seleção de linhagens com atividades catabolíticas interessantes.

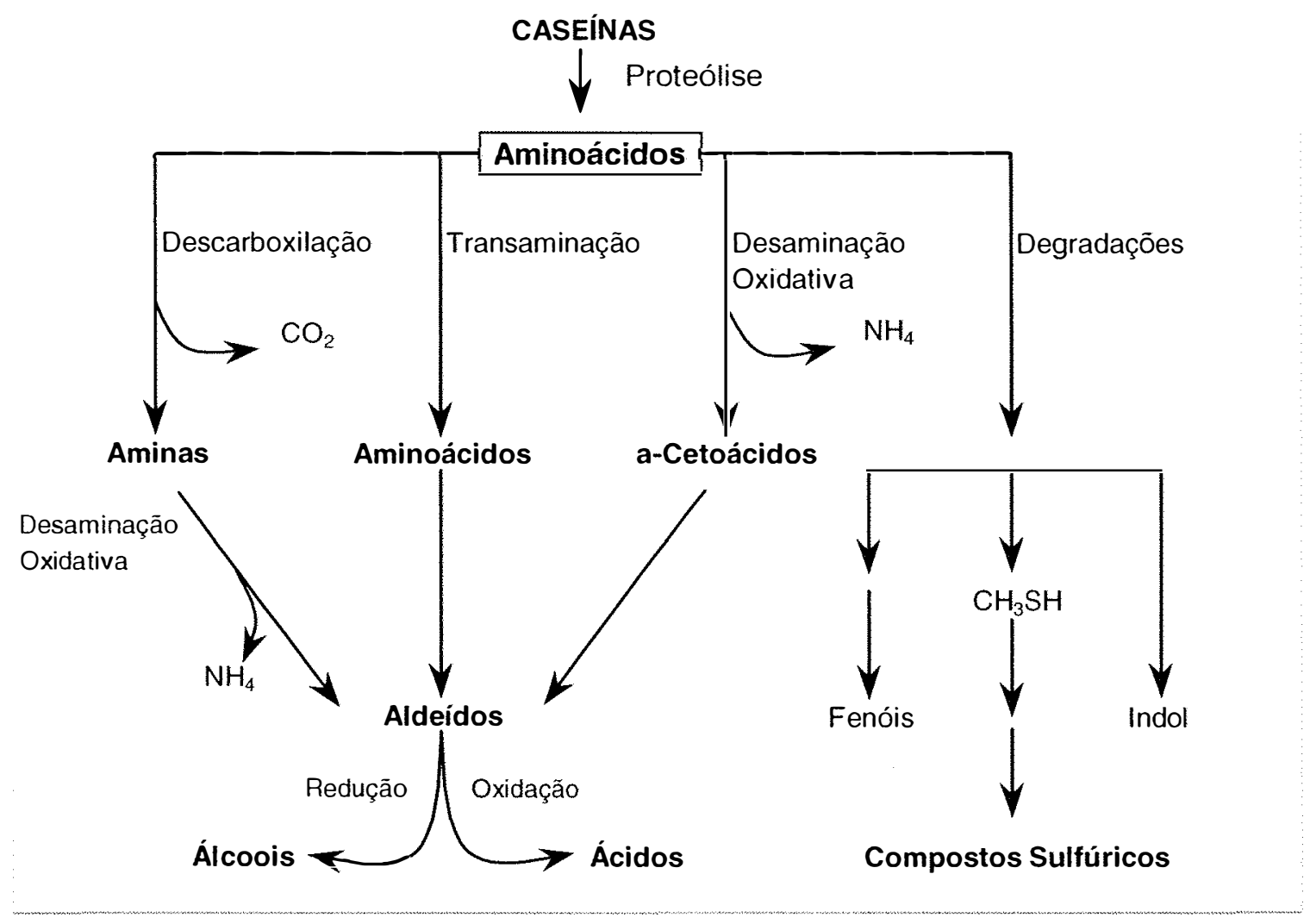

Figura 8 - Principais vias do catabolismo de aminoácidos (Adaptado de Hemme et al., 1982).

\subsubsection{Avaliação dos compostos neutros voláteis do flavour por CG-MS}

A análise dos compostos neutros voláteis em queijos é sempre realizada através de cromatografia gasosa (CG) com espectrometria de massa (MS), porém, antes desses voláteis serem analisados, eles devem ser isolados do queijo. Para tanto, vários métodos podem ser utilizados, havendo, normalmente, o inconveniente de suas recuperações serem variáveis e de haver a formação de artefatos. Um método que tem sido preferido por pesquisadores é a análise por headspace, que utiliza o equilíbrio existente entre os componentes voláteis de uma amostra líquida ou sólida e a fase gasosa 
circundante em um utensílio de vidro fechado hermeticamente. No caso de queijos, o headspace é a mistura de vapor que é emitida da superfície do queijo ou de um extrato de queijo, que é analisada introduzindo-se o utensílio de vidro especial diretamente no cromatrógrafo a gás. Usando este tipo de análise, resultados quantitativos podem ser obtidos (Manning \& Moore, 1979).

A CG-MS é uma técnica sensível que permite a identificação e a quantificação dos compostos voláteis em queijos. Infelizmente, é inadequada para o uso rotineiro em indústrias de laticínios devido ao elevado custo do instrumento e da análise por amostra (Mc Seewney \& Fox, 1997b).

A metodologia que utiliza a CG-MS para analisar os compostos aromáticos em queijos mede todos os compostos voláteis, enquanto que, somente uma pequena fração de voláteis são ativos ao olfato humano. Visando identificar os compostos importantes em queijos para o odor, estão sendo desenvolvidos métodos analíticos que combinam a cromatografia a gás e a olfatometria. Com essas metodologias associadas, estão sendo observados que metade dos odorantes mais fortes resultam principalmente da fermentação da lactose ou da degradação do citrato e poucos da lipólise, enquanto que a outra metade resulta da degradação da leucina e metionina. Os principais compostos aromáticos produzidos a partir da metionina são metional, metanetiol e seus produtos de oxidação, como o dimetilsulfito (DMDS) e dimetiltrisulfito (DMTS), enquanto o ácido isovalérico e o 3-metil butanal resultam da degradação da leucina (Yvon \& Rijnen, 2001).

A identificação de compostos aromáticos chaves de vários tipos de queijos mostram que a degradação de aminoácidos é o maior processo envolvido na formação de aroma em queijos e que os aminoácidos aromáticos (fenilalanina, tirosina, triptofano), aminoácidos de cadeia ramificada (leucina, isoleucina e valina) e metionina são os maiores precursores desses compostos aromáticos (Yvon \& Rijnen, 2001). 


\subsubsection{Aceleração da produção de flavour durante a maturação de queijos}

A maturação de queijos é um processo lento e consequentemente custoso, ainda não totalmente controlado. O custo de um queijo maturado é dependente do tempo em que o mesmo foi mantido em câmaras para atingir o grau de maturação desejado. Esse período varia muito com o tipo de queijo em questão, que pode ser de 4 semanas para queijos de massa mole, como o Camembert e de até 4 anos para algumas variedades de queijos duros, como o Parmesão (El Soda, 1997). Devido à importância econômica desse processo e à atenção dada por parte de muitos pesquisadores, diversos métodos estão sendo desenvolvidos e testados para reduzir o período de maturação e melhorar o desenvolvimento de flavour (sabor e aroma) em queijos (El Soda \& Pandian, 1991; Wilkinson, 1993; Wallace \& Fox, 1997). O principal objetivo de acelerar as várias vias bioquímicas é reduzir o período de maturação sem afetar negativamente o sabor, o aroma e a textura de um queijo (Wilkinson, 1993).

Pelo fato da proteólise ser vista como o evento bioquímico de maior expressividade durante a maturação de quase todas as variedades de queijos (Fox, 1989; El Soda, 1997), a maioria dos trabalhos realizados para acelerar a sua maturação, envolve a aceleração da degradação da caseína e de peptídeos (El Soda \& Pandian, 1991; Wilkinson, 1993), embora saiba-se, atualmente, que nem sempre aumentando-se os teores de peptídeos e aminoácidos livres no interior do queijo, haverá maior formação de compostos do flavour (Wallace \& Fox, 1997; Yvon \& Rijnen, 2001).

As estratégias tradicionalmente utilizadas para acelerar a maturação de queijos envolvem a inoculação de enzimas ( $\beta$-galactosidade, proteases, peptidases e lipases) (Law \& Wigmore, 1983), geralmente associadas à elevação da temperatura da câmara de maturação (Cromie et al., 1987), devido ao processamento e a maturação serem, por definição, processos essencialmente enzimáticos (El Soda, 1997; Fox \& Stepaniak, 1993). No entanto, pesquisas demonstraram que a adição de enzimas livres no interior do queijo, provocaram reações bioquímicas incontroláveis e, consequentemente, levavam a defeitos no sabor, no aroma e na textura (Wilkinson, 1993; El Soda, 1993). Isso levou a buscas por novos métodos para acelerar o processo de 
maturação, que estão ganhando destaque atualmente, como a adição de enzimas encapsuladas (Spangler et al., 1989) e a utilização de fermento láctico modificados geneticamente, através de mutação (Kamaly et al., 1989; El Soda et al., 1992) ou físicamente, através de atenuação (El Soda et al., 1991; Johnson \& Etzel, 1995; Kebary et al., 1996).

Uma análise de publicações referentes à aceleração da maturação feita por El Soda (1993), indicou que o número desses trabalhos era bastante limitado até o início dos anos 70 e, a partir de então, mais de 300 artigos foram publicados. As publicações dos anos 80, eram direcionadas à adição de enzimas livres, provenientes de diversos recursos, no leite de fabricação ou na coalhada. Já no final dos anos 80 e início dos anos 90, houve maior interesse por parte dos pesquisadores em utilizar células intactas do fermento láctico de forma atenuada (Klein \& Lortal, 1999), o que vem sendo a tendência atual.

Não é o objetivo desta revisão relatar os estudos que foram realizados até o presente momento para acelerar a maturação de queijos. Na literatura especializada, encontram-se revisões sobre as mais recentes realizações nessa área (Law, 1987; Fox, 1989; El Soda \& Pandian, 1991; El Soda, 1993; Visser, 1993; Wilkinson, 1993; El Soda, 1997; Klein \& Lortal, 1999).

Em conclusão, a proteólise é considerada uma etapa crucial na obtenção de queijos maturados, pois determina sua textura e formação do flavour. Muitos pesquisadores já tentaram acelerar essa etapa através de diversos meios, alguns com sucesso, aumentando particularmente a temperatura de maturação, adicionando enzimas ou modificando características de bactérias lácticas associadas ao aumento da atividade proteolítica no queijo. Em termos de formação de sabor e aroma, a proteólise ainda é tida como uma etapa importante, mas, atualmente, muita atenção tem sido voltada à etapa seguinte, de transformação de aminoácidos em compostos voláteis. 


\subsection{Considerações sobre os queiJos Saint Paulin e Minas Frescal}

\subsubsection{Saint Paulin}

O queijo Saint Paulin tradicional é de origem francesa, prensado, de massa semi-dura, com formato cilíndrico (20-22 cm de diâmetro e 5-6 cm de espessura) ou retangular. Apresenta textura compacta e elástica e coloração amarelo-claro; a casca é fina. Possui um teor de gordura no extrato seco entre 45 e 50 \% (Cenzano, 1992).

Geralmente fabricado com leite de vaca integral, pasteurizado, o queijo Saint Paulin é também fabricado em algumas indústrias com um teor de gordura reduzido e com fermento láctico mesofílico misto (Lactococcus lactis subsp. lactis, $L$. lactis subsp. cremoris, L. lactis subsp. diacetylactis). A massa é lavada. Após a prensagem, os queijos são mantidos à temperatura ambiente até atingirem $\mathrm{pH}$ 5,6-5,7 e colocados em salmoura. A primeira maturação ocorre em um câmara a $19^{\circ} \mathrm{C}$ e $90 \%$ de umidade por 5 a 6 dias, sendo virados regularmente e inoculados com solução contendo Brevibacterium linens e Micrococcus. Ao final desse período, os queijos apresentam-se com a casca escorregadia e alaranjada. São levados para uma câmara mais seca (85\% de umidade relativa) e mais fria $\left(15^{\circ} \mathrm{C}\right)$ e virados a cada 2 dias durante a segunda maturação. Uma maturação típica do Saint Paulin deve totalizar 6 a 8 semanas, quando os queijos são secos e embalados ou parafinados (Albuquerque \& Castro, 1995; Robinson, 1995).

Por ser um queijo de massa semi-dura, ou seja, com extrato seco entre 45 a 48\%, o queijo Saint Paulin somente foi possível de ser fabricado através do processo MMV após o desenvolvimento das membranas minerais (terceira geração) no início dos anos 80. Isso porque, para atingir tal extrato seco, sem a necessidade de dessoragem da massa, é preciso obter um retentado com fator de concentração (fc) ao redor de 6, o que 
não era praticável com as antigas membranas (à base de polímeros), devido à limitada resistência mecânica ao entupimento e de outros fatores intrínsecos (Ducruet et al., 1981). A fabricação do Saint Paulin utilizando Ultrafiltração foi descrita pela primeira vez por Goudédranche et al. (1981), quando definem condições ótimas para a sua obtenção, caracterizando pré-queijos submetidos a vários tratamentos tecnológicos de acidificação, pressões hidrodinâmicas, variações de temperatura e modo de salga. Assim, propõem fabricá-lo a partir de leite pasteurizado, padronizado a 2,8 \% em gordura e Ultrafiltração conduzida a $50-56^{\circ} \mathrm{C}$. Quando o retentado atinge um fc igual a 6 , faz-se a diafiltração, adicionando água a $50^{\circ} \mathrm{C}$ de forma contínua, ou seja, o processo de Ultrafiltração não é interrompido, até atingir novamente fc igual a 6. Dá-se o início ao trabalho com o pré-queijo, adicionando-se $0,5 \%$ de $\mathrm{NaCl}$ e o fermento láctico ( $2 \% \mathrm{em}$ peso). Inicia-se a fermentação a $30^{\circ} \mathrm{C}$ até que o retentado atinja um valor de $\mathrm{pH}$ por volta de 5,0-5,2. Adiciona-se novamente $\mathrm{NaCl}(1,0 \%)$, seguindo-se da adição do coalho comercial (40 ml/100 kg, força 1/10000), mexedura vigorosa e enformagem em fôrmas com diâmetro de $200 \mathrm{~mm}$ e $105 \mathrm{~mm}$ e altura de $60 \mathrm{~mm}$. 30 minutos após a adição do coalho, transfere-se a massa para fôrmas cilíndricas clássicas, onde é mantida a temperaturas decrescentes de $28-20^{\circ} \mathrm{C}$ durante um período de $16-20$ horas. Faz-se a desenformagem e os queijos são secos e levados para câmara de maturação a $12-14^{\circ} \mathrm{C}$ por, no mínimo, 15 dias.

\subsubsection{Minas Frescal}

O Minas Frescal é um queijo típico brasileiro, desenvolvido tradicionalmente em pequenas propriedades produtoras de leite em Minas Gerais e atualmente apreciado em todo país. É um queijo fresco, destinado ao consumo imediato, não necessitando maturação e de curta durabilidade no mercado. Seu processo de fabricação é bastante simples e seu rendimento bastante elevado, por isso é fabricado tanto em indústrias de pequeno e médio porte como em grandes indústrias (Furtado \& Lourenço-Neto, 1994). 
Segundo as Normas e Diretivas do Mercosul (Portaria $\mathrm{n}^{\circ} 352$, de 4 de setembro de 1997) o Minas Frescal é fabricado com leite de vaca, pasteurizado $\left(72^{\circ} \mathrm{C} / 15\right.$ seg. ou $65^{\circ} \mathrm{C} / 30$ min.), com acidez entre 15 e $18^{\circ} \mathrm{D}$ e teor de gordura 3,2 a $3,5 \%$. Apresenta formato cilíndrico e peso entre 500 e 3.000 g. Sua coloração é esbranquiçada, textura fechada ou aberta, com poucas olhaduras mecânicas, consistência mole e sabor de suave a ligeiramente ácido. O rendimento de fabricação varia entre 5 e 7 1/kg. O teor de umidade é de 55 até $60 \%, 15$ a $19 \%$ em gordura, 1,0-1,6 \% de sal. Segundo Furtado (1999), o Minas Frescal pode ser feito com o uso de fermentos lácticos mesofílicos (0,1$0,5 \%$ ) ou sem nenhum fermento, porém com a adição de ácido láctico (entre 20 e $25 \mathrm{ml}$ de ácido $85 \%$ puro para cada 100 litros de leite. Sua durabilidade é pequena (cerca de 10 dias no mercado), sendo bastante influenciado pela composição físico-química, principalmente a umidade, como também pelas condições a que é submetido na cadeia do frio.

O queijo Minas Frescal apresenta vários pontos críticos durante a fabricação que podem conduzir a alterações no produto final, podendo apresentar-se tanto com acidez excessiva como insuficiente, com reflexos no desenvolvimento de contaminações. Essas alterações influenciam a umidade final, o sabor do queijo, o rendimento e a durabilidade, afetando diretamente as características sensoriais e, consequentemente, a aceitabilidade pelo consumidor e comercialização (Furtado \& Lourenço-Neto, 1994). Por apresentar elevado teor de umidade e elevada quantidade de lactose, açúcar facilmente decomposto nas diversas fermentações susceptíveis de ocorrer em um queijo, o Minas Frescal é um queijo facilmente perecível. A acidificação, fenômeno causado pela atuação das bactérias do fermento láctico, é apontada como a causa mais freqüente da deterioração do Minas Frescal no mercado (Wolfschoon-Pombo et al., 1978).

Por ser um queijo de massa mole, o Minas Frescal pode ser também fabricado através do processo MMV (item 2.1) que, embora modifique as características organolépticas do produto original, tem tido grande aceitabilidade no comércio nacional. Do ponto de vista econômico é vantajoso, principalmente devido ao aumento de 
rendimento e à maior durabilidade do produto no mercado, por ser menos manipulado nesse processo automatizado.

Vieira et al. (1983) foram os primeiros pesquisadores a delinear os parâmetros de fabricação para obtenção de um novo queijo fresco do tipo Minas Frescal através do processo MMV, diretamente na embalagem de comercialização. Segundo esse estudo, o leite integral $(3,5 \%$ em MG; $\mathrm{pH}=6,6)$ é ultrafiltrado até um fator de concentração (fc) igual a 3, quando é feita a retirada da lactose pela diafiltração, e concentra-se até fc igual a 4,5 . Esse retentado é resfriado a $32^{\circ} \mathrm{C}$, quando é adicionada a cultura láctica, dando início à fermentação, que é conduzida durante 1:30h (pré-queijo). O sal e o coalho são adicionados, seguindo-se do condicionamento em potes plásticos. Com esse processo, há possibilidade de aumento na durabilidade do queijo pela melhoria na qualidade higiênica, como conseqüência da diminuição de manipulação do produto.

Van Dender et al. (1999) compararam as alterações físico-químicas do queijo Minas Frescal fabricados pelo processo MMV e tradicional durante o armazenamento. Observaram que os queijos UF mantiveram suas características próprias de sabor e textura por 14 dias sob refrigeração $\left(5 \pm 2^{\circ} \mathrm{C}\right)$, apresentando menor acidificação e menor taxa de proteólise com relação ao queijo tradicional, o que no caso de queijos frescos é um fator desejado. Observaram, ainda, que apesar dos queijos fabricados pelos métodos MMV e tradicional terem apresentado composição química semelhante, suas características organolépticass e reológicas (textura) foram sensivelmente diferentes. No caso do MMV, a diferença também se deve à principal característica desta tecnologia, que consiste na fabricação de queijos coagulados diretamente na embalagem, sem corte ou dessora da coalhada e que conservam, portanto as características do gel formado, ou seja, apresentam massa lisa e homogênea. 


\section{ROMPIMENTO MECÂNICO FÁCIL E EFICIENTE DE Lactobacillus helveticus, Lactococcus lactis E Propionibacterium freudenreichii ATRAVÉS DE UM NOVO HOMOGENEIZADOR PILOTO À ALTA PRESSÃO}

\section{Trabalho Original: Apêndice 2}

Luciana Viriato SABOYA ${ }^{1}$, Marie-Bermadete MAILLARD ${ }^{2}$, Sylvie LORTAL ${ }^{2 *}$

'Escola Superior de Agricultura "Luiz de Queiroz" (ESALQ - USP) Av. Pádua Dias, 11 Caixa Postal 9; 13418-900, Piracicaba, SP - Brasil.

${ }^{2}$ Laboratoire de Recherche de Technologie Laitière (LRTL - INRA) 65, rue de Saint Brieuc, 35042 Rennes Cedex, France.

\section{RESUMO}

Estudos microbiológicos freqüentemente envolvem fracionamento de células bacterianas e sabe-se que bactérias gram (+) são mais difíceis de serem rompidas do que bactérias gram (-). O rompimento de células pode ser obtido através de vários tratamentos mecânicos. O objetivo desse trabalho foi estudar a eficiência de rompimento de espécies gram (+), utilizando um homogeneizador-piloto à alta pressão.

Várias pressões $(50,100$ e $200 \mathrm{MPa})$ foram aplicadas a suspensões bacterianas concentradas $(1,2 \mathrm{mg}$ peso seco/ml) de Lactobacillus helveticus, Lactococcus lactis e Propionibacterium freudenreichii. A eficiência de rompimento foi estimada pelo decréscimo da densidade ótica a $650 \mathrm{~nm}$, do peso seco celular e da viabilidade celular. As proteínas liberadas foram quantificadas e a atividade residual de uma aminotransferase foi estimada. Uma passagem à pressão de $50 \mathrm{MPa}$ foi suficiente para romper $80 \%$ de células de Lactobacillus helveticus enquanto $200 \mathrm{MPa}$ foram 
necessários para obter a mesma eficiência para L. lactis e $P$. freudenreichii. Independente da pressão aplicada, a atividade da leucina-aminotransferase foi recuperada no sobrenadante após o tratamento das suspensões de células de todas as espécies em homogeneizador.

Esse novo homogeneizador-piloto à alta pressão é um meio rápido (20 s/passagem), fácil, contínuo e altamente eficiente para o rompimento de células bacterianas. As espécies testadas não eram filogeneticamente relacionadas, possuindo morfologia e composição distintas da parede celular. Assim, concluiu-se que a maioria das bactérias gram $(+)$ podem ser rompidas eficientemente através desse novo aparelho.

Palavras-chaves: rompimento de células; homogeneização à alta pressão, aminotransferase; liberação de proteína, Propionibacterium, Lactobacillus, Lactococcus.

\section{SUMMARY}

Microbiological studies often involve bacterial cell fractionation, which is known to be difficult in gram (+) compared to gram (-) bacteria. Cell disruption can be achieved by various mechanical treatments. Our purpose was to test the breaking efficiency of a new high-pressure pilot homogenizer toward gram (+) species.

Varied pressures $(50,100$ and $200 \mathrm{MPa})$ were applied to concentrated bacterial suspensions (1,2 mg dry weight/ml) of Lactobacillus helveticus, Lactococcus lactis and Propionibacterium freudenreichii. The breaking efficiency was estimated by the decrease of optical density at $650 \mathrm{~nm}$, of cellular dry weight and of viability. The proteins released were quantified and the residual activity of an intracellular aminotransferase was estimated. One run at $50 \mathrm{MPa}$ was sufficient to break $80 \%$ of lactobacilli cells whereas $200 \mathrm{MPa}$ were required for the same efficiency for $L$. lactis and $P$. freudenreichii. Whatever the pressure, leucine aminotransferase activity was recovered in the supernatant of breaking.

This new high-pressure pilot homogenizer can allow a rapid (20 s/run), easy, continuous and highly efficient cell breaking. As the species tested were not 
phylogenetically related, having different morphologies and cell wall composition, we concluded that most gram (+) bacteria can be efficiently broken by this new device.

Keywords: cell disruption; high-pressure homogenizer; aminotransferase; protein release, Propionibacterium, Lactobacillus, Lactococcus.

\subsection{INTRODUÇÃO}

Estudos microbiológicos freqüentemente envolvem o fracionamento de células bacterianas. Essa etapa é necessária para recuperar enzimas intracelulares ou compostos de baixo peso molecular. Pode ser ainda utilizada para o preparo de parede celular para sua subseqüente caracterização (Salton \& Horne, 1951) ou para estudos de enzimas associadas à parede celular, como as autolisinas (Rogers, 1980). Comparandose bactérias gram (-) a bactérias gram (+), estas últimas são mais difíceis de serem rompidas devido à sua espessa multicamada de peptideoglicano.

O rompimento de células bacterianas pode ser obtido através de tratamentos mecânicos ou enzimáticos. Em escala de laboratório, o rompimento é provocado por diferentes tipos de prensas (prensa Francesa, prensa X), por sonificação, por grade com alumina ou vortex com bolas de vidro (Mc Illwain, 1948; French \& Milner, 1955, Hummel \& Kula, 1989). Para a maioria das espécies gram (+), a eficiência de rompimento raramente ultrapassa $50 \%$ do número inicial de células com uma única passagem. Assim, o preparo de grandes quantidades de parede celular de células gram (+) através de tal metodologia, pode ser bastante dificultosa e demandar muito tempo. Os tratamentos enzimáticos existem como uma alternativa mais branda envolvendo lisozima (muramidase, EC 3.2.1.17), mutanolisina (Yokogawa et al., 1975; Siegel et al., 1981) ou purificação de endolisinas de fagos (como a lisostafina), todas hidrolisando ligações do peptideoglicano. Como ocorre menor taxa de desnaturação, quando comparados ao rompimento físico, esses tratamentos requerem freqüentemente uma otimização para cada espécie e, muitas vezes, para cada linhagem (Chassy \& Giuffrida, 
1980). Além disso, o peptideoglicano (O ou N-acetilado) pode ser resistente à atividade da lisozima e ainda requerer o emprego de mutanolisina, que é uma enzima lítica cara. Obviamente que os tratamentos utilizando enzimas líticas são excluídas, se o objetivo é isolar paredes celulares e, em particular, peptideoglicano.

Os homogeneizadores à alta pressão surgiram nos anos 70 . O princípio mecânico do rompimento celular é o mesmo da prensa Francesa (descompressão explosiva), mas que comparado a todos os métodos citados, é o único que trabalha continuamente. Por isso, o processo de rompimento de células em larga escala freqüentemente envolve vários homogeneizadores (Follows et al., 1971; Kula \& Schütte, 1987; Middelberg, 1995). No entanto, existem relativamente poucos dados na literatura. Por exemplo, a homogeneização foi aplicada em E. coli, B. subtilis e numa levedura em um homogeneizador comercial a pressões ao redor de $55 \mathrm{MPa}$, levando a uma taxa de rompimento de 12 to $67 \%$, em uma só passagem, dependendo do tipo de microrganismo, entre outros fatores (Gray et al., 1972; Higgins et al., 1978; para revisão, ver Engler, 1985).

Atualmente, os homogeneizadores-piloto à alta pressão possuem válvulas fabricadas a partir de cerâmica, com um novo formato, propiciando maior resistência mecânica que possibilita a aplicação de pressões instantâneas bastante elevadas que chegam a $350 \mathrm{MPa}$. Este trabalho relata os experimentos utilizando esse novo aparelho para o rompimento eficiente de espécies bacterianas gram $(t)$ com diferentes morfologias: Lactobacillus helveticus (bacilos), Lactococcus lactis (cocos) e Propionibacterium freudenreichii (caracteres chineses). Estas espécies foram escolhidas devido: i) às suas distintas morfologias que podem resistir diferentemente às pressões aplicadas e ii) ao vasto emprego e interesse dessas espécies em tecnologia de laticínios, sendo que o seu fracionamento para o estudo de enzimas intracelulares é freqüentemente necessário. 


\subsection{Material E MÉtodos}

\subsubsection{Origem e crescimento das linhagens}

As linhagens Lactobacillus helveticus CNRZ 243 e Lactococcus lactis NCDO 763, obtidas da coleção do CNRZ (INRA Jouy en Josas, França), foram estocadas a $-80^{\circ} \mathrm{C}$ em meio MRS com glicerol (Difco, Detroit, MI 48232, USA) e em M17 (Terzaghi \& Sandine, 1975), respectivamente. Propionibacterium freudenreichii TL 24 (CNRZ 725) foi obtida da coleção do Laboratoire de Recherches de Technologie Laitière (TL, INRA, Rennes) e estocada em meio de lactato de sódio (Malik et al., 1968). O meio foi suplementado com $15 \%$ de glicerol antes do congelamento. Para a propagação das linhagens, os mesmos meios, sem glicerol, foram utilizados e o crescimento foi monitorado a $37^{\circ} \mathrm{C}$ para $L$. helveticus e $30^{\circ} \mathrm{C}$ para as outras duas espécies, através de densidade ótica a 650nm $\left(\mathrm{DO}_{650}\right)$.

\subsubsection{Homogeneização}

Quando a D.O.650 1 era atingida (peso seco de 0,25 a $0,35 \mathrm{mg} / \mathrm{ml}$, dependendo da espécie), células cultivadas a partir de um litro de meio de cultura eram recolhidas por centrifugação $\left(9000 \mathrm{~g}, 10 \mathrm{~min}, 4^{\circ} \mathrm{C}\right)$, lavadas duas vezes e suspensas em $240 \mathrm{ml}$ de água destila estéril para obter a concentração celular final ao redor de $10^{9} \mathrm{ufc} / \mathrm{ml}$. Suspensões celulares foram mantidas em gelo até sua utilização. $15 \mathrm{ml}$ da suspensão foram mantidas sob refrigeração como o branco (To). O restante da suspensão foi dividido em 3 partes de $75 \mathrm{ml}$ e submetido ao rompimento pelo homogeneizadorpiloto (Standsted, fluid power LTD) às pressões de 50, 100 e $200 \mathrm{MPa}$ sob fluxo refrigerado. $100 \mathrm{ml}$ da suspensão bruta foram recolhidos em cada caso e imediatamente conservados em gelo. O efeito da diluição da homogeneização foi levado em consideração, isto é, a testemunha foi levada ao mesmo fator de diluição (25 \%), 
permitindo, assim, comparações com as suspensões tratadas. Uma parte da amostra foi centrifugada $\left(10000 \mathrm{~g}, 10 \mathrm{~min}, 4^{\circ} \mathrm{C}\right)$ e o sobrenadante (extrato intracelular livre de células - CFE) foi recolhido para análises subseqüentes. Para cada espécie, 2 ensaios independentes foram realizados e os resultados foram expressos através da média.

\subsubsection{Viabilidade celular}

Antes e após o tratamento de homogeneização, a viabilidade celular foi determinada pelo plaqueamento em meios de cultura específicos para cada espécie, contendo $1,2 \%$ de ágar. As placas foram incubadas por 2 dias a $30^{\circ} \mathrm{C}$ para L. lactis e $P$. freudenreichii (anaerobiose) e a $37^{\circ} \mathrm{C}$ para L. helveticus (anaerobiose). Os resultados foram expressos como porcentagem da viabilidade inicial.

\subsubsection{Peso seco celular}

Alíquotas de $3 \mathrm{ml}$ das suspensões celulares (testemunha e após homogeneização) foram centrifugadas $\left(10.000 \mathrm{~g}, 10 \mathrm{~min}, 4^{\circ} \mathrm{C}\right) . \mathrm{O}$ precipitado celular foi ressuspenso em água fria destilada esterilizada, conservado a $-18^{\circ} \mathrm{C}$ até secagem em equipamento Speed Vac (Savant Instruments, New York) e seguido de pesagem para estimar o peso seco celular residual. O sobrenadante foi conservado para a determinação de proteínas, SDS-PAGE e análises da leucina-aminotransferase.

\subsubsection{Determinação de proteína}

A absorbância do sobrenadante a $280 \mathrm{~nm}$ (D.O.280) foi medida usando o espectrofotômetro DU 7400 (Beckman). O conteúdo de proteína também foi determinado através do procedimento de Bradford (1976) usando um kit de tratamento (Biorad microprocedure, Hercules, CA, USA), com soro albumina bovino (Sigma) como padrão. 


\subsubsection{SDS-PAGE}

A análise em SDS-PAGE foi realizada usando gel de separação a $14 \%$ em acrilamida $(8 \times 8 \mathrm{~cm})$ e o gel de estaqueamento a $4 \%$, como descrito por Valence \& Lortal (1995). A análise de eletroforese foi conduzida a 180V durante 1 hora. As amostras foram ressuspensas em tampão Laemmli v/v (Laemmli, 1970) e fervidas por 3 min antes de serem aplicadas no gel. Os géis foram coloridos usando Azul de Coomassie R250 (Sigma).

\subsubsection{Atividade da leucina-aminotransferase}

A atividade da leucina-aminotransferase foi determinada de acordo com Yvon et al. (1997). $20 \mu \mathrm{l}$ dos extratos intracelulares (CFE - sobrenadante de homogeneização) foram adicionados a $150 \mu \mathrm{l}$ da seguinte mistura: Tris- $\mathrm{HCl}$ (Merck) 70 $\mathrm{mM}$ pH 8,0 contendo $4 \mathrm{mM}$ de leucina (Sigma), $10 \mathrm{mM}$ de $\alpha$-cetoglutarato de sódio (Sigma), $50 \mu \mathrm{M}$ Piridoxal $5^{\prime}$-fosfato (Sigma). A incubação foi feita a $37^{\circ} \mathrm{C}$ durante 2 a 18 horas. O ácido glutâmico foi analisado enzimaticamente com o kit Boerhinger (Diffchamb, Lyon, França). Um branco, sem o aminoácido leucina, foi incluído como controle. Reagentes: Leucina, $\alpha$-cetoglutarato, piridoxal 5'-fosfato foram obtidos de Sigma Aldrich (St Quentin, Fallavier, França).

\subsection{Resultados E Discussão}

\subsubsection{Eficiência do rompimento de células}

Para as três espécies, os índices de rompimento celular estavam todos em concordância: decréscimo na DO $650 \mathrm{~nm}$, peso seco celular e contagem de células 
(Figura 9a,b,c). A eficiência de rompimento aumentou claramente com a pressão aplicada, mas de três formas diferentes, segundo a espécie bacteriana em questão. As curvas de tendência foram, respectivamente, potencial para $L$. helveticus, linear para $L$. lactis e logarítmica para $P$. freudenreichii. Além disso, mais de $80 \%$ de rompimento celular foram obtidos em uma única passagem a $50 \mathrm{MPa}$ para L. helveticus, enquanto apenas uma pressão de $200 \mathrm{MPa}$ foi necessária para P. freudenreichii e L. lactis. A passagem duplicada pela pressão de $200 \mathrm{MPa}$, no caso de propionibactéria, ocasionou somente um pequeno aumento no rompimento celular (Figura 9c). Lanciotti et al. (1994) quando aplicaram pressões de 15 a $200 \mathrm{MPa}$ em microrganismos patogênicos, observaram uma relação log-linear entre as células sobreviventes e as pressões aplicadas. De acordo com Engler (1985), a forma e a resistência da parede celular parece depender dos polímeros estruturais dentro da parede no qual eles estão ligados de forma cruzada entre si e aos outros componentes da parede celular. Para romper uma célula, a maior resistência que deve ser superada é a ligação covalente de sua rede estrutural. O melhor mecanismo de ruptura de células através de homogeneização à alta pressão somente foi investigado com mais detalhes recentemente para uma levedura (Kleinig \& Middelberg, 1998). Nesse estudo, a morfologia bacteriana mostrou possuir um efeito significativo sobre a eficiência de rompimento, visto que bastonetes (lactobacilos) mostraram-se muito mais frágeis com relação à homogeneização, quando comparados aos cocos (lactococos) ou às células pleiomórficas como as de propionibactéria. Ademais, a porcentagem da viabilidade residual foi similar àquela do peso seco celular, o que indica que a maioria das células não-rompidas, não estão drasticamente danificadas, mas ainda continuam vivas e viáveis. Esse ponto poderia ser facilmente confïmado por microscopia de fluorescência, usando coloração indicadora para células vivas e mortas. 


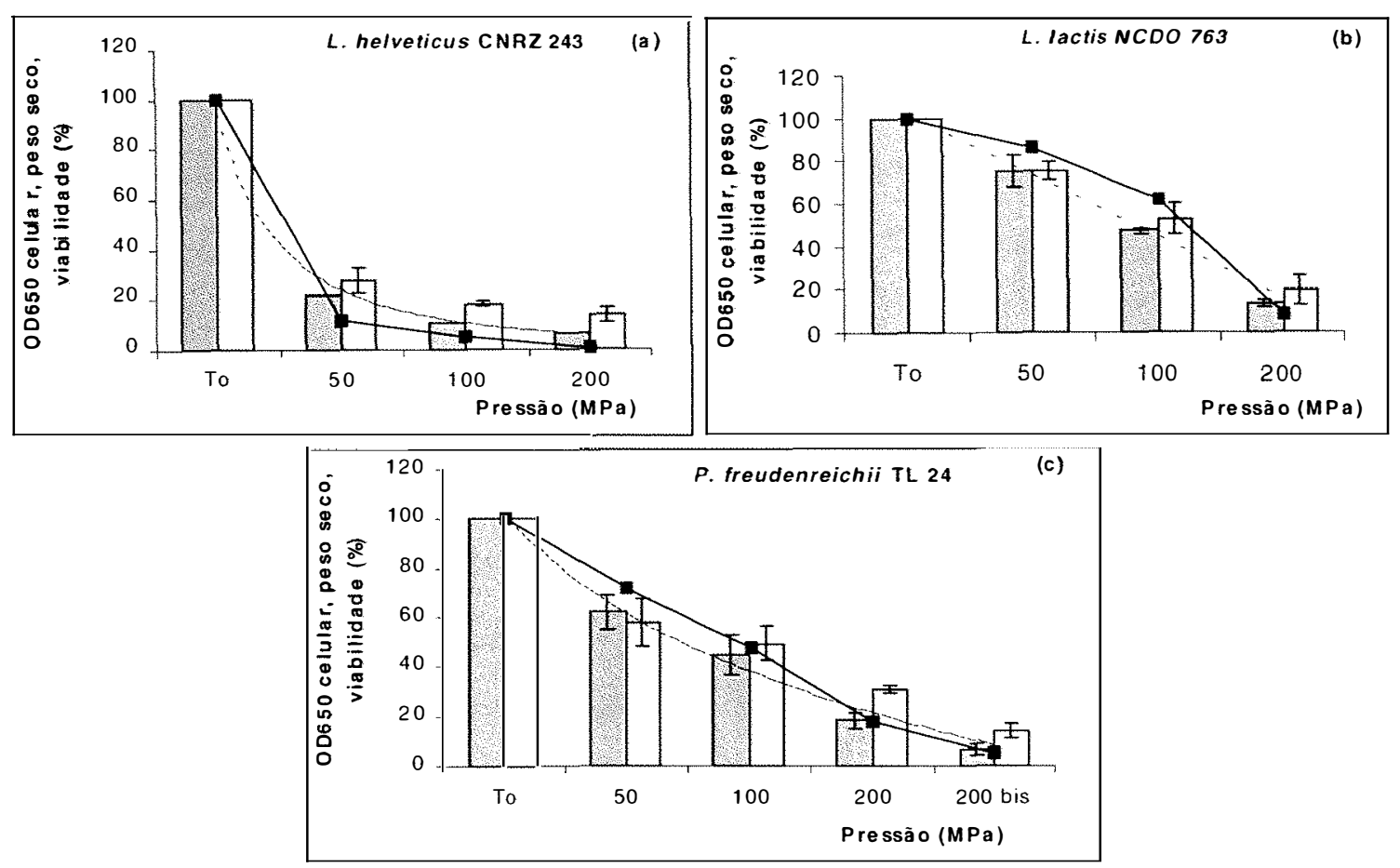

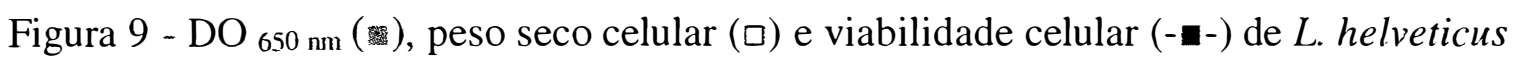
CNRZ 243 (a), L. lactis subsp. lactis NCDO 763 (b) e P. freudenreichii TL 24 (c) quando submetidos à Homogeneização a pressões de 50, 100 e $200 \mathrm{MPa}$. (---) Curvas de tendência.

Ainda, suspensões dez vezes concentradas de propionibactéria foram submetidas à homogeneização a $200 \mathrm{MPa}$ e obteve-se a mesma eficiência de rompimento celular (dados não mostrados). Este resultado está de acordo com a literatura, indicando que o desempenho do homogeneizador não diminui com o aumento da concentração celular, até o nível em que esta obstrua a operação e a torne impraticável (Engler \& Robinson, 1979; Engler, 1985).

\subsubsection{Análises das proteínas liberadas no sobrenadante de homogeneização}

Independente da análise efetuada $\left(\mathrm{A}_{280 \mathrm{~nm}}\right.$, estimativa de proteína ou SDSPAGE), nenhuma proteína foi detectada no sobrenadante do controle. Além disso, no 
sobrenadante dos homogeneizados, o aumento da quantidade de proteína liberada mostrou-se coerente e correspondente com a porcentagem de células rompidas para cada espécie (Figura 10 e Figura 11). Assim, obviamente, qualquer que fosse o método usado para detecção de proteínas, a maioria das proteínas de Lb. helveticus já haviam sido quase todas liberadas no tratamento a $50 \mathrm{MPa}$, o que é coerente com a elevada eficiência de rompimento a essa pressão para tal espécie (>80 \%).
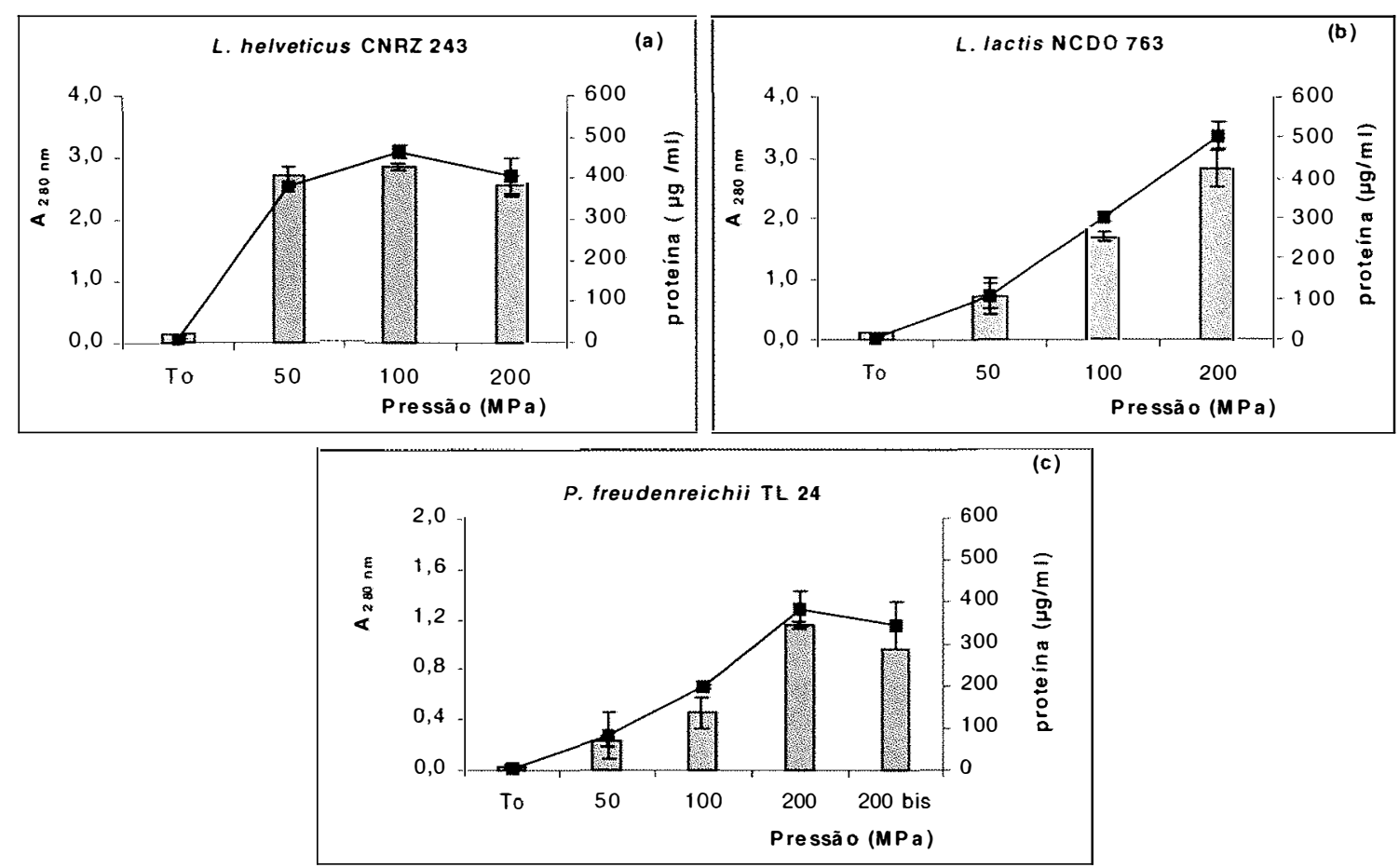

Figura 10 - DO $280 \mathrm{~nm}(\mathbf{m})$, proteína ( $\mu \mathrm{g} / \mathrm{ml})$ (-m-) de L. helveticus CNRZ 243 (a), L. lactis subsp. lactis NCDO 763 (b) e P. freudenreichii TL 24 (c) quando submetidos ao Homogeneizador a pressões de 50, 100 e 200 MPa.

Por outro lado, surpreendentemente, no caso de propionibactéria, 25-30\% a menos de proteína foi liberada quando comparada com lactococos, para a mesma eficiência de rompimento (a 100 e $200 \mathrm{MPa}$ ). Isso pode refletir diferenças na relação proteínas da membrana celular / proteínas citoplasmáticas, visto que a primeira mostrouse ser liberada de forma mais fácil e rápida através de tratamento com Homogeneizador (Engler, 1985). 


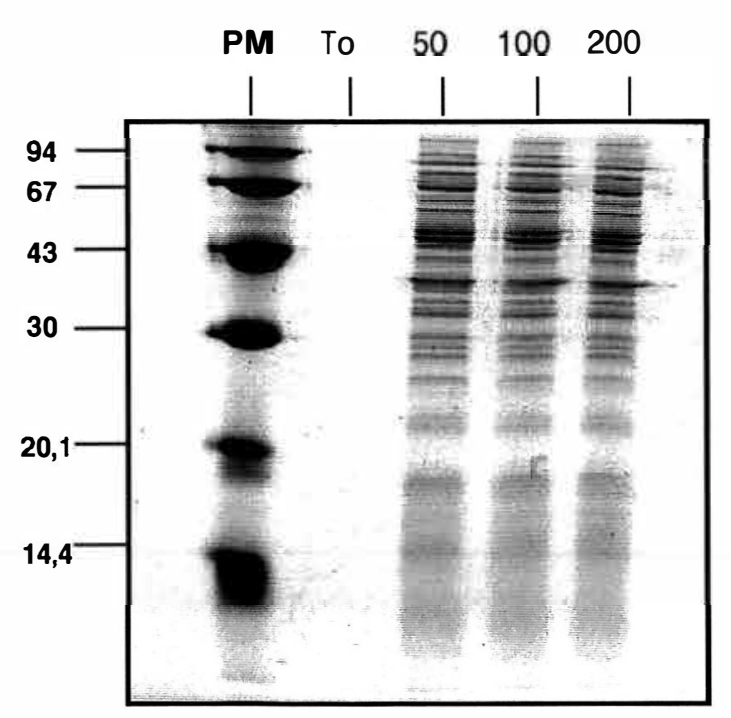

(a)

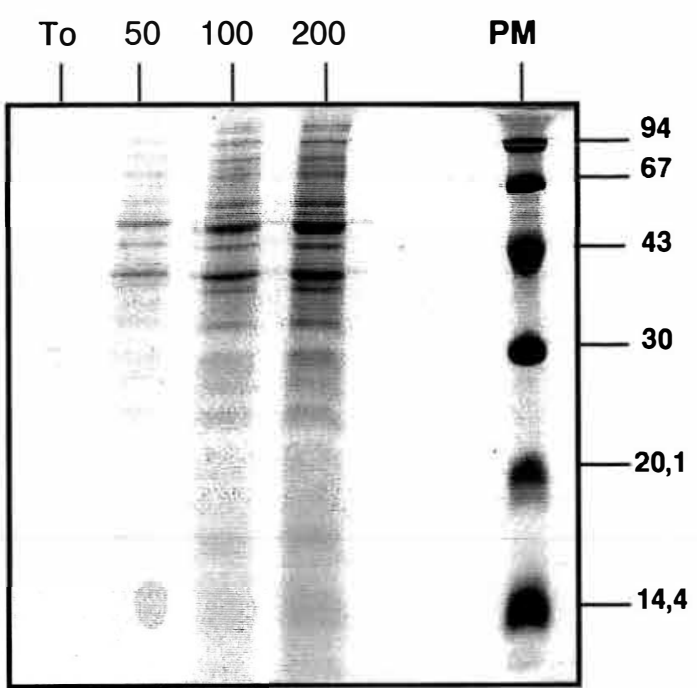

(b)

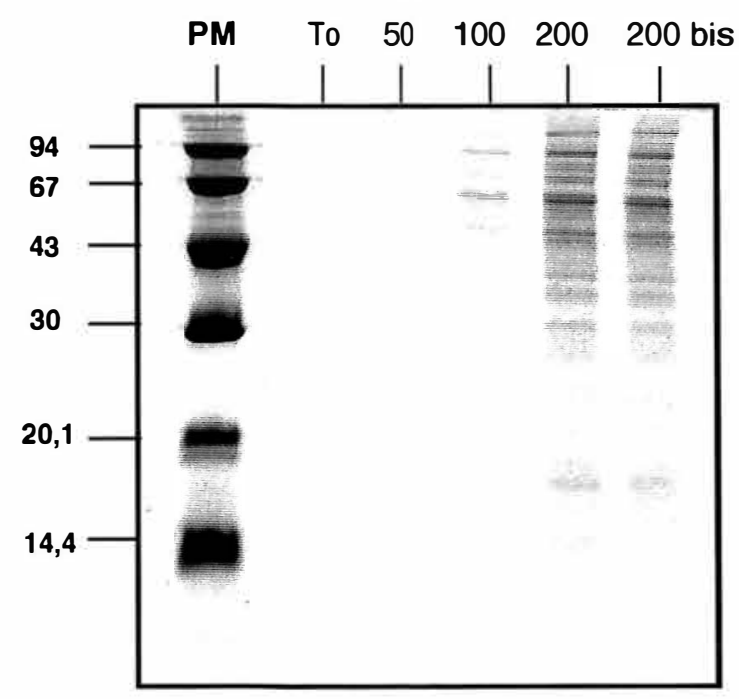

(c)

Figura 11 - SDS-PAGE mostrando as proteínas de L. helveticus CNRZ 243 (a), L. lactis subsp. lactis NCDO 763 (b) e P. freudenreichii TL 24 (c) liberadas pela homogeneização, dependendo da pressão aplicada (indicada em cada linha). $\mathrm{PM}=$ pesos moleculares padrões $(\mathrm{kDa})$. 


\subsubsection{Atividade de leucina-aminotransferase}

Todas as linhagens estudadas, $L$. helveticus, L. lactis e P. freudenreichii possuem atividade leucina-aminotransferase. Demonstrou-se que essa enzima possui uma função-chave na maturação de queijos, sendo atualmente o objeto de vários estudos (Yvon et al.,1997; Klein et al., 2001; Thierry et al., 2001). De forma a avaliar o impacto da homogeneização sobre essa enzima intracelular, sua atividade foi estimada por miligrama de proteína liberada. Independentemente da espécie estudada e da pressão aplicada, a leucina-aminotransferase foi detectada no sobrenadante de homogeneização (Figura 12) não tendo sido observada perda drástica de atividade nas duas repetições, independentes da homogeneização, mesmo a elevadas pressões.

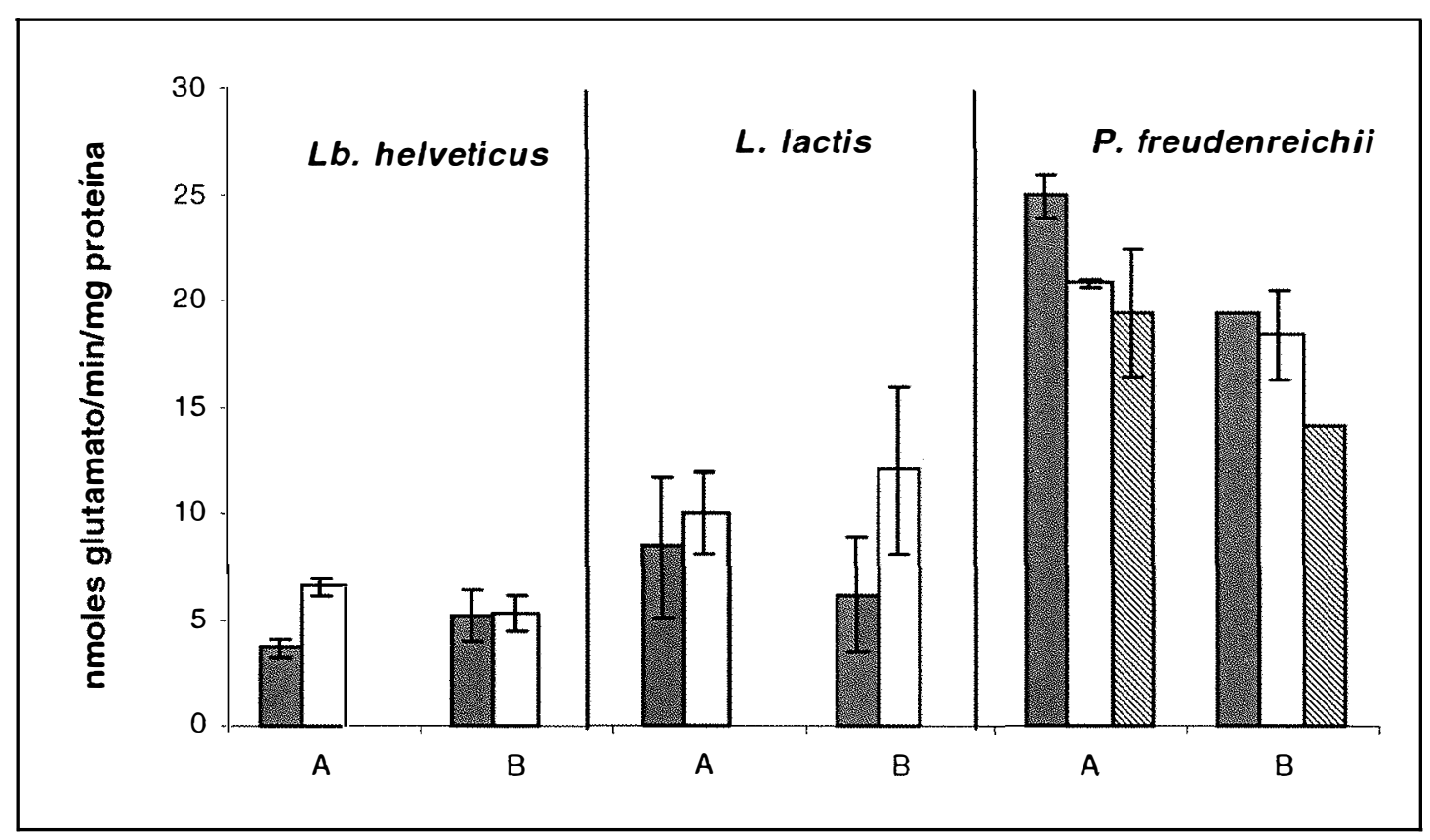

Figura 12- Atividade leucina-aminotransferase ( $\mathrm{nmol} / \mathrm{min} / \mu \mathrm{g}$ proteína) de extratos livres de células de L. helveticus CNRZ 243, L. lactis subsp. lactis NCDO 763 e $P$. freudenreichii TL 24, obtidos em duas homogeneizações diferentes (A e B)

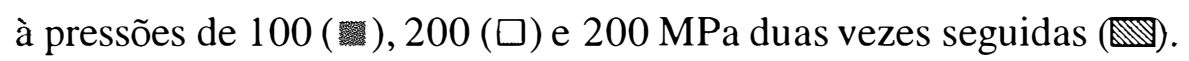




\subsection{Conclusões}

O homogeneizador-piloto à alta pressão usado neste estudo mostrou ser um meio muito eficiente para romper bactérias gram-positivas, morfologicamente distintas, de forma fácil e rápida (poucos segundos), num sistema contínuo. Isso é possível graças à nova válvula de descompressão, fabricada a partir de cerâmica, com um formato preciso e com capacidade de distribuir pressões instantâneas bastante elevadas (até $350 \mathrm{MPa}$, valores máximos, não testados aqui). Para as três espécies estudadas, a atividade de uma enzima intracelular, a leucina-aminotransferase, foi recuperada no sobrenadante de homogeneização e resistiu à pressão mais elevada aplicada (200 MPa). Sugere-se, então, que esse novo homogeneizador-piloto é um aparelho adequado a preparar enzimas citoplasmáticas ativas de bactérias grampositivas. 


\title{
4 IMPACTO DE CÉLULAS ROMPIDAS DE LACTOCOCOS E PROPIONIBACTÉRIA ATRAVÉS DE HOMOGENEIZAÇÃO NA MATURAÇÃO DE QUEIJOS ULTRAFILTRADOS: EXTENSÃO DA PROTEÓLISE E PERFIL EM CG-MS
}

\author{
Artigo Original: Apêndice 3 \\ Luciana Viriato SABOYA', Henri GOUDEDRANCHE ${ }^{2}$, Jean-Louis MAUBOIS ${ }^{2}$, Alda Luiza \\ Santos LERAYER ${ }^{3}$, Sylvie LORTAL ${ }^{2}$ \\ 'Escola Superior de Agricultura "Luiz de Queiroz" (ESALQ - USP) \\ Av. Pádua Dias, 11 Caixa Postal 9; 13418-900, Piracicaba, SP - Brasil. \\ ${ }^{2}$ Laboratoire de Recherches de Technologie Laitière (LRTL - INRA) \\ 65, rue de Saint Brieuc, 35042 Rennes Cedex, France. \\ ${ }^{3}$ Instituto de Tecnologia de Alimentos (ITAL - Tecnolat) \\ Avenida Brasil, 2880; 13073-001, Campinas, SP - Brasil
}

\section{RESUMO}

Os queijos ultrafiltrados desenvolveram-se com muito sucesso em vários países. No entanto, a proteólise e, por conseqüência, o tempo de maturação desses queijos são nitidamente mais lentos do que naqueles fabricados através de tecnologia tradicional. A ausência de lise do fermento láctico é apontada como uma das possíveis causas da maturação ser retardada. Neste trabalho, células de $P$. freudenreichii e de Lactococcus sp. foram rompidas com o auxílio de um novo homogeneizador-piloto à alta pressão. As suspensões de células brutas rompidas (CBS) ou os extratos intracelulares (CFE) obtidos após centrifugação foram adicionados aos retentados de UF, com fator de concentração igual a 6 para fabricação de queijo tipo Saint Paulin, 
seguindo-se da acidificação por um fermento mesofílico comercial. Água destilada e esterilizada foi adicionada à testemunha. A proteólise foi estimada medindo-se os teores de NCN, NPN e aminoácidos livres; os compostos voláteis neutros por CG-MS. Para o queijo testemunha, a proteólise foi muito limitada e a ausência de lise do fermento comercial (L. lactis) foi de fato demonstrada. A adição de CBS ou de CFE de Lactococcus sp. aumentaram os teores em aminoácidos livres (1,5 a 3 vezes), ao contrário da adição de CBS ou de CFE de $P$. freudenreichii, mesmo quando a temperatura de maturação foi elevada de $12^{\circ} \mathrm{C}$ para $20^{\circ} \mathrm{C}$. Por outro lado, a adição de CBS de $P$. freudenreichii ocasionou um aumento nos teores de compostos voláteis: álcoois e cetonas. A não-existência de efeito similar, quando adicionou-se CFE, mostra a necessidade da presença de células inteiras. A adição de CBS ou CFE de Lactococcus sp. não ocasionou nenhuma mudança significativa nos teores em compostos aromáticos. Conclui-se, portanto, que a adição de homogeneizados de suspensões celulares pode modificar a maturação de queijos UF. A adição de outras linhagens e de outras espécies deve ser agora explorada.

Palavras-chaves: Ultrafiltração, queijo-UF, perfil CGMS, homogeneizados celulares, proteólise, maturação, Lactococcus, Propionibacterium.

\section{SUMMARY}

UF-cheeses have been successfully developed in many countries. However, proteolysis and general extent of ripening were shown to be far slower compared to traditional varieties. The absence of starter lysis has been cited as a plausible explanation. In this work, propionibacteria and lactococci cells were disrupted using a new pilot homogenizer. Crude broken suspension (CBS), or cell-free extract (CFE) obtained after centrifugation, were added to UF-St Paulin retentate (concentration factor 6) made with an usual lactic starter. RO water was added to the control. Proteolysis was estimated by NCN, NPN and free amino acids. Neutral volatile compounds were determined by GC-MS. A low extent of ripening was noted in the control and the absence of starter lysis was effectively proved using immunodetection of 
lactococci cytoplasmic proteins. The addition of lactococci CBS or CFE increased free amino acid content (1.5 to 3 fold) whereas propionibacteria CBS or CFE exhibited no significant increase, even when cheeses were ripened at $20^{\circ} \mathrm{C}$ instead of $12^{\circ} \mathrm{C}$. By contrast, addition of propionibacteria CBS generated a significant increase in several volatile compounds like alcohols and ketones, whereas CFE did not, showing that the presence of live cells was required to form these compounds. CBS or CFE of lactococci did not significantly change the volatile compound profile. In conclusion, it was possible to influence the ripening of UF-cheese by the addition of crude broken bacterial cells suspensions. Other strains and species should be now investigated.

Key words: Ultrafiltration, UF-cheese, GC-MS profile, broken cells, ripening, proteolysis, Lactococcus, Propionibacteria.

\subsection{INTRODUÇÃO}

Introduzido a 32 anos atrás por Maubois, Mocquot \& Vassal (1969), o processo mundialmente conhecido como MMV, atingiu desenvolvimento comercial em muitas variedades de queijos adaptados aos hábitos e à cultura de cada região no mundo. Exemplos disso são os queijos do tipo fresco, massa mole e semi-duros, tais como Pavé d'Affinois e Saint Paulin na França (Goudédranche et al., 1981; Kosikowski, 1985), Feta na Dinamarca e no Iran (Wagner \& Rubin, 1979), Minas Frescal no Brasil (Vieira et al., 1983; Van Dender 1999), Quarg na Alemanha (Patel et al., 1986), Twarog na Polônia (Omar \& Hosaja, 1986), Teleme na Grécia (Veinoglou \& Boyazoglu, 1982), Ricota e Cream Cheese nos USA (Covacevich \& Kosikowski, 1977; Maubois \& Kosikowski, 1978), bem como os queijos do tipo duro como o Cheddar ou os do tipo Suíço, fabricados a partir do conceito LCR (low concentration retentate) (Green et al., 1981; Mistry \& Maubois, 1993). O sucesso do processo MMV pode ser explicado através das vantagens econômicas por ele proporcionadas. O rendimento de fabricação é significativamente aumentado (até $20 \%$ ) devido à incorporação das proteínas do soro na 
coalhada; requer-se menor quantidade de coalho; reduzem-se as perdas de gordura no soro e o processo de fabricação do queijo é simplificado (Goudédranche et al., 1981; Lawrence 1989; Pedersen \& Ottosen, 1992). Além disso, a concentração diferencial das proteínas do leite e da gordura, após a coagulação, acarreta nos queijos UF uma textura mais macia e mais homogênea, quando comparados aos queijos tradicionais (Lawrence, 1989). Essa propriedade é interessante, pois possibilita a criação de novas variedades de queijos.

Entretanto, para as variedades de queijos UF maturados, fabricados a partir de retentados 5 vezes ou totalmente concentrados, a proteólise e a extensão geral da maturação são mais lentas do que nas variedades fabricadas pelo processo tradicional (Spangler et al., 1989; De Koning et al., 1981). Essa desvantagem é freqüentemente atribuída à presença de proteínas do soro que são incorporadas nos queijos UF (De Koning et al., 1981; Lawrence, 1989; Bech, 1993). No entanto, essa hipótese é ainda motivo de controvérsias (Mistry \& Maubois, 1993). De fato, a principal razão para a maturação lenta pode ser provavelmente devido à elevada capacidade tamponante dos queijos UF, que faz com que a taxa da autólise do fermento láctico seja retardada (Goudédranche et al., 1986) e consequentemente, a hidrólise da caseína. A função negativa do elevado conteúdo de sais de cálcio dos queijos-UF já foi enfatizada em 1974 por Brulé et al., sugerindo várias maneiras para ajustar o conteúdo mineral dos retentados de UF: reduzindo o $\mathrm{pH}$ do leite antes ou durante a Ultrafiltração, aumentando a força iônica pela adição do $\mathrm{NaCl}$, ou pelos dois métodos associados (Mistry \& Maubois, 1993). As proteínas do soro em queijos fabricados pelo processo MMV são como um enchimento inerte, como sugerido por De Koning et al. (1981) devido a sua resistência à hidrólise pela quimosina, proteases do fermento láctico e a plasmina (Qvist et al., 1987; De Koning et al., 1981). O elevado conteúdo de $\beta$-lactoglobulina nos queijos UF, também poderia exercer uma certa inibição sobre a atividade das proteases (Bech, 1993; Jameson \& Lelievre, 1996).

Para acelerar a maturação de queijos UF, os mesmos métodos usados para melhorar a maturação de queijos tradicionais podem ser utilizados: i) aumento da 
temperatura de maturação; ii) adição de fermentos atenuados (Klein \& Lortal, 1999); iii) adição de extratos livres de células (Engels \& Visser, 1996); iv) aumento da população microbiana ou de bactérias que não sejam as do fermento láctico; v) adição de proteases ou lipases ou vi) combinação de métodos (Fox, 1989; El Soda \& Pandian, 1991; El Soda, 1993). Algumas dessas ferramentas já foram testadas. Hickey et al. (1983) adicionaram uma linhagem proteolítica, Lactobacillus helveticus YB 1, juntamente com o fermento láctico. Eles verificaram que o nível de aminoácidos livres no queijo Cheddar por UF aumentou com relação àquele observado no queijo tradicional, adicionado somente com a linhagem L. lactis subsp. cremoris E8. Goudédranche et al. (1986) melhoraram a textura, o sabor e o aroma do queijo Saint Paulin e Camembert fabricados por UF adicionando 0,5 ou $1,0 \mathrm{~g} / \mathrm{kg}$ de lisozima nos pré-queijos líquidos. Eles observaram um pequeno aumento na proteólise durante a maturação e um melhoramento nas qualidades organolépticas nesses queijos. Bastian et al. (1991), adicionando uroquinase aos queijos UF Havarti e Saint Paulin, de forma a ativar a plasmina, observaram um aumento nos níveis de NPN e de NCN e uma maior degradação da $\beta$ caseína que foram correlacionados com o pequeno aumento no sabor e aroma. Spangler et al. (1989) aceleraram a maturação do queijo UF-Gouda adicionando uma mistura de enzimas encapsuladas em liposomas e de Lactobacillus helveticus atenuado através de choque por congelamento, seguido de descongelamento (freeze shocked). Esses autores observaram um aumento significativo nos níveis de nitrogênio solúveis em TCA e PTA, aroma mais intenso e ausência de desenvolvimento de sabor amargo.

A adição de quantidades extras de proteases e peptidases de bactérias, como sugerido por Bech (1993), de forma a aumentar a hidrólise da caseína nunca fora descrita anteriormente. Os retentados de UF são ainda um material de estudo interessante, pois toda a gama de enzimas adicionadas é retida na coalhada e subseqüentemente no queijo, que é uma enorme vantagem comparada com os queijos fabricados através de tecnologia tradicional, onde $90 \%$ das enzimas adicionadas são perdidas no soro. 
O objetivo desse estudo foi investigar o impacto da adição de suspensões de células brutas rompidas (CBS, uma mistura de células inteiras, paredes celulares e extratos intracelulares) ou de somente extratos intracelulares (CFE) de Lactococcus sp. e Propionibacterium freudenreichii na maturação do queijo UF-Saint Paulin. A ruptura das células foi realizada usando um novo homogeneizador-piloto à alta pressão, descrito recentemente (Saboya et al., 2002).

\subsection{MATERIAL E MÉTODOS}

\subsubsection{Origem das linhagens e condições de crescimento}

Uma mistura comercial liofilizada de Lactococcus lactis subsp. lactis, $L$. lactis subsp. cremoris e L. lactis subsp. diacetilactis (MM 101 - EZAL, Rhodia-Texel, Dangé Saint Romain, França) foi conservada a $4^{\circ} \mathrm{C}$. Propionibacterium freudenreichii TL 24 (CNRZ 725) foi obtida da coleção de cultura do Laboratoire de Recherches de Technologie Laitière (INRA, França). Essa cultura foi estocada a $-18^{\circ} \mathrm{C}$ em meio YEL (Malik et al., 1968) e adicionada de glicerol (15\% v/v), sendo cultivada em mesmo meio a $30^{\circ} \mathrm{C}$.

\subsubsection{Preparo das suspensões celulares e do rompimento de células}

$10 \mathrm{~g}$ do fermento liofilizado Lactococcus sp. MM 101/10u foram suspensos em $100 \mathrm{ml}$ de água destilada esterilizada $\left(3,5 \times 10^{10} \mathrm{ufc} / \mathrm{ml}\right)$. $P$. freudenreichii TL 24 foi primeiramente cultivada em caldo YEL por 24 horas a $30^{\circ} \mathrm{C}$ até $\mathrm{OD}_{650} \sim 1$, quando, então, as células foram recolhidas por centrifugação $\left(9.000 \mathrm{~g}, 10 \mathrm{~min}, 4^{\circ} \mathrm{C}\right) \mathrm{e}$ ressuspensas em $240 \mathrm{ml}$ de água tratada por osmose reversa (O.R.) e esterilizada para atingir a concentração celular de $2,5 \times 10^{10} \mathrm{ufc} / \mathrm{ml}$. $75 \mathrm{ml}$ das suspensões celulares de $P$. 
freudenreichii TL 24 e de Lactococcus sp. foram submetidos ao homogeneizador-piloto Stansted/fluid power LTD (Sodexim, França) (Foto: Anexos Cl e C2) para a ruptura das células à pressão de $200 \mathrm{MPa}$, como descrito anteriormente (Saboya et al., 2002). 30ml da suspensão tratada, contendo células intactas, células rompidas e uma gama de enzimas intracelulares foram coletadas e denominadas suspensão bruta (CBS - crude broken suspension). O restante da suspensão foi centrifugado $\left(10.000 \mathrm{~g}, 15 \mathrm{~min}, 4^{\circ} \mathrm{C}\right)$ para eliminar as células inteiras e os fragmentos maiores da parede celular. $30 \mathrm{ml}$ do sobrenadante foram coletados e denominado suspensão intracelular (CFE - cells free extracts). A eficiência do rompimento celular foi verificado através da viabilidade celular em meio de cultura específico para a espécie em questão, antes e após o tratamento de homogeneização, como descrito por Saboya et al. (2002).

\subsubsection{Ultrafiltração e fabricação dos queijos UF}

Dois grupos de experimentos foram conduzidos com diferentes aparelhos de UF como descrito a seguir. Em ambos os casos, o leite foi primeiramente padronizado a $2,8 \%$ em teor de gordura e pasteurizado a $90^{\circ} \mathrm{C} / 4$ segundos (Actijoule pilot, Société Actini, França). A temperatura durante o processo de UF foi de $48-50^{\circ} \mathrm{C}$. Foi feita uma diluição a 1,12 vol/vol com água tratada por osmose reversa (O.R.) quando o retentado atingiu um fator de concentração de 6 vezes. A UF deu continuidade até a obtenção de um retentado com um conteúdo de sólidos totais de 40g /100g (Foto: Anexo C4). O retentado foi, então, imediatamente resfriado a $30^{\circ} \mathrm{C}$ e inoculado com o fermento Lactococcus sp. MM 101. O pó liofilizado foi diluído em leite, de forma a obter $10^{7}$ $\mathrm{ufc} / \mathrm{ml}$ de retentado. $0,75 \%(\mathrm{p} / \mathrm{p})$ de $\mathrm{NaCl}$ foram, então, adicionados. A fermentação deu-se durante 18 horas a $30^{\circ} \mathrm{C}$ e mais $0,65 \%$ de $\mathrm{NaCl}$ foram colocados. $\mathrm{O}$ retentado foi dividido em várias partes e adicionaram-se CBS e CFE como descrito a seguir.

Para os experimentos envolvendo os homogeneizados de células de Lactococcus sp. MM101 como aditivo, o leite foi ultrafiltrado usando um equipamento de Ultrafiltração-piloto com membranas CARBOSEP M1 (poder de corte da membrana 
- cut-off - de 150 kDa e uma superfície de 6,8 $\mathrm{m}^{2}$ - Sociedade Rhodia-Orelis, França) (Foto: Anexo C3) durante 80 minutos. O retentado foi dividido em quatro partes de $6 \mathrm{~kg}$ e tratados da seguinte forma:

a) $\mathrm{UF}$ controle $=$ retentado $+30 \mathrm{ml}$ água O.R. esterilizada

b) UF/CBS Lac $5 \mathrm{ml}=$ retentado $+5 \mathrm{ml}$ lactococos $\mathrm{CBS}+25 \mathrm{ml}$ água O.R. esterilizada

c) $\mathrm{UF} / \mathrm{CBS} \mathrm{Lac} 30 \mathrm{ml}=$ retentado $+30 \mathrm{ml}$ lactococos $\mathrm{CBS}$

d) UF/ CFE Lac $30 \mathrm{ml}=$ retentado $+30 \mathrm{ml}$ lactococos CFE

Para o experimento envolvendo suspensões de células rompidas de $P$. freudenreichii como aditivo, foi utilizado um equipamento de UF piloto com membranas MEMBRALOX (membrana com tamanho de poro de 0,05 $\mu \mathrm{m}$ e superfície de $1,8 \mathrm{~m}^{2}$ Société T.I.A., França). O processo de UF foi realizado durante $120 \mathrm{~min}$. O retentado foi divido em três partes de $6 \mathrm{~kg}$ e tratados da seguinte forma:

a) $\mathrm{UF}$ controle $=$ retentado $+30 \mathrm{ml}$ água O.R. esterilizada

b) UF/ CBS Prop $30 \mathrm{ml}=$ retentado $+30 \mathrm{ml}$ P. freudenreichii CBS

c) UF/ CFE Prop $30 \mathrm{ml}=$ retentado $+30 \mathrm{ml} P$. freudenreichii $\mathrm{CFE}$

1,8 $\mathrm{ml}$ de coalho foi diluído 5 vezes em água O.R. (SKW Biosystems) e adicionado em cada retentado que, após completa homogeneização, foram vertidos em formas plásticas de 26 × 36 × 10,5 cm e mantidos a $30^{\circ} \mathrm{C}$ (Foto: Anexo C5). Duas horas depois, quando os pré-queijos encontravam-se firmes, foram cortados em 12 blocos de $10 \times 9 \times 8,5 \mathrm{~cm}$ (Foto: Anexo C6) e incubados por mais 4 horas a $30^{\circ} \mathrm{C}$ quando, então, os queijos foram desenformados e mantidos a $12^{\circ} \mathrm{C}$, durante 5 semanas (Foto: Anexo C7). Após três dias, os queijos foram recobertos com um filme plástico. Uma parte dos queijos adicionados de homogeneizados de $P$. freudenreichii TL 24 foi levada a $20^{\circ} \mathrm{C}$, após 10 dias, sob $12^{\circ} \mathrm{C}$. Os queijos foram maturados até $\mathrm{D}+27$ ou $\mathrm{D}+45$, no caso daqueles adicionados de extratos intracelulares de Lactococcus sp. (Foto: Anexo C8). 


\subsubsection{Composição química dos queijos UF}

Amostras de queijos foram tomadas após 1, 7, 13, 20 e 27 dias. Um dia após a fabricação, determinaram-se o pH, sólidos totais, gordura, sal, lactose e nitrogênio total. Os valores do $\mathrm{pH}$ foram estimados através de um potenciômetro padrão CG837 com eletrodos InLAB 427 (Mettler Toledo, França) pela introdução direta nos queijos. Os valores de sólidos totais (EST) foram medidos pela secagem a $102( \pm 2)^{\circ} \mathrm{C}$ durante 7 horas, de acordo com as normas da International Dairy Federation (IDF, 1982). A gordura foi determinada usando o método de Van Gulik (FIL, 1997). O teor de sal foi determinado usando o equipamento "Chloruremetre Corning 926" (Humeau Laboratoires, França). A lactose residual dos queijos foi avaliada segundo o método de Dubois et al. (1956). O nitrogênio total (NT) dos queijos foi determinado pelo método de Kjeldahl, usando o fator de correção igual a 6,38, segundo as normas da IDF (1962).

A proteólise dos queijos foi determinada durante 5 semanas através da evolução dos níveis de nitrogênio solúvel em pH 4,6 (nitrogênio não caseínico ou NCN) e de nitrogênio solúvel em TCA a 12 \% (nitrogênio não protéico ou NPN), de acordo com Gripon et al. (1975) com relação aos níveis de nitrogênio total. Os resultados foram expressos em porcentagem do nitrogênio total no queijo.

\subsubsection{Análises bacteriológicas}

Amostras de queijos (10 g) foram tomadas em vários períodos durante a maturação e diluídas em $90 \mathrm{~g}$ de citrato tri-sódico $(20 \mathrm{~g} / \mathrm{l})$ usando o aparelho Waring Blendor (Prolabo, F-94126 Fontenay-sous-Bois, França), de início funcionando em baixa velocidade por 20 segundos, seguindo-se em alta velocidade por 40 segundos, de forma a obter uma suspensão homogênea. Diluições decimais foram preparadas a partir dessa suspensão. A viabilidade de Lactococcus sp. foi determinada através da técnica de semeadura sob placas em meio M17 adicionado de 1,2 \% de ágar (Terzaghi \& Sandine, 1975), após incubação a $30^{\circ} \mathrm{C}$ por 48 horas. A viabilidade de Propionibacterium foi 
determinada usando o meio seletivo LGA (Madec et al., 1993) contendo 1,2 \% de ágar; as placas semeadas foram incubadas sob anaerobiose a $30^{\circ} \mathrm{C}$ por $5-6$ dias. Os resultados foram expressos como logaritmo (log) de unidades formadoras de colônia (ufc) por grama de queijo.

\subsubsection{Extrato aquoso do queijo}

Extratos aquosos de queijos foram obtidos como descrito por Valence et al. (2000). As amostras de queijos (4,5 g) foram diluídas em $18 \mathrm{ml}$ de água O.R. esterilizada e homogeneizadas manualmente em sacos plásticos estéreis com filtros (Humeau, França). As soluções foram recolhidas e centrifugadas a $10.000 \mathrm{~g}, 4^{\circ} \mathrm{C}$ por 15 minutos. Os sobrenadantes, isto é, os extratos aquosos dos queijos, foram filtrados em uma membrana com poros de tamanho de $0,45 \mu \mathrm{m}$ (Sartorius, F-91127 Palaiseau, França) e mantidos a $-18^{\circ} \mathrm{C}$ até sua utilização.

\subsubsection{Análises em SDS-PAGE}

As proteínas contidas nos extratos aquosos dos queijos, bem como em CBS e CFE obtidos em homogeneizador, foram analisadas através de géis de poliacrilamida em condição desnaturante (SDS-PAGE) como descrito por Valence \& Lortal (1995). As amostras foram misturadas (v/v) em tampão Laemmli (1970) e adicionadas no gel (a $14 \%$ de separação). A migração foi realizada a $25^{\circ} \mathrm{C}$ sob voltagem constante de $180 \mathrm{~V}$ por $1: 30 \mathrm{~h}$.

\subsubsection{Autólise da cultura láctica acidificante}

A autólise da cultura láctica Lactococcus sp. foi controlada durante o período de maturação, usando anticorpos produzidos contra extratos intracelulares de $L$. 
cremoris (denominados LC-cytosol). Dessa maneira, células de Lactococcus cremoris CNRZ 205 foram coletadas durante a fase exponencial de crescimento $\left(\mathrm{OD}_{650}\right.$ de 0,8$)$ por centrifugação $\left(7.000 \mathrm{~g}, 20 \mathrm{~min}, 15^{\circ} \mathrm{C}\right)$ e lavadas duas vezes em água O.R. esterilizada (15\% do volume inicial do meio de cultura). Os precipitados celulares foram, então, estocados a $-20^{\circ} \mathrm{C}$ por 48 horas antes de serem ressuspensos em água O.R. esterilizada e gelada (6\% do volume inicial do meio de cultura) e submetida à Prensa Francesa, previamente resfriada, à pressão de $138 \mathrm{MPa}$ por 3 minutos (duas passagens). As suspensões foram centrifugadas $\left(48.000 \mathrm{~g}, 30 \mathrm{~min}, 4^{\circ} \mathrm{C}\right)$ de forma a eliminar células não rompidas e partes da parede celular. O sobrenadante foi ultracentrifugado a $150.000 \mathrm{~g}$ durante 3 horas a $4^{\circ} \mathrm{C}$ para eliminação de ribossomos. $\mathrm{O}$ sobrenadante obtido foi denominado LC-citosol. Anticorpos policlonais foram produzidos por dois coelhos contra o LC-citosol obtido como descrito previamente (100 $\mu \mathrm{g}$ de proteína por injeção, durante 6 semanas de imunização) (Eurogentec, Seraing, Bélgica).

As proteínas contidas nos extratos aquosos dos queijos foram separadas através de SDS-PAGE, seguido-se da transferência através de Western-Blotting (1:15h, corrente constante de $250 \mathrm{~mA})$ em uma folha de nitrocelulose $(0,45 \mu \mathrm{m}$ de tamanho do poro, Millipore, F-78051 St Quentin en Yvelines, França). Proteínas citossólicas de L. cremoris foram detectadas com soro anti-LC-citosol (estocadas a $-30^{\circ} \mathrm{C}$ e diluídos a 1/2500 em PBS-tween no momento antes da utilização. O anticorpo Horseradish peroxidase-conjugated goat anti-rabbit IgG $(\mathrm{H}+\mathrm{L})-\mathrm{HRP}$ conjugate (Biorad) foi usado como um anti-soro secundário com DAB (3,3'diaminobenzidina tetrahidroclorina) (Amresco, Solon, USA) como revelador (Valence et al., 1998).

\subsubsection{Aminoácidos livres}

O conteúdo de aminoácidos livres dos queijos foi determinado após a desproteinização das amostras pelo ácido sulfosalicílico (Merk-Eurolab, Grosseron S.A., Saint Herblain, França) de acordo com Mondino et al. (1972). Extratos aquosos de queijos $(1 \mathrm{ml})$ foram tratados com $50 \mathrm{mg}$ de ácido sulfosalicílico, misturados por 15 
segundos e incubados por 1 hora a $4^{\circ} \mathrm{C}$. As misturas foram centrifugadas a $5.000 \mathrm{~g}$ por 15 min a $4^{\circ} \mathrm{C}$. Os sobrenadantes foram filtrados em membranas com poros de $0,45 \mu \mathrm{m}$ (Sartorius, F-91127 Palaiseau, França) e o filtrado foi diluído 6 vezes em tampão de citrato de lítio 0,2 M pH 2,2 antes da injeção. As análises dos aminoácidos através de cromatografia de troca iônica foram realizadas usando o equipamento Pharmacia LKB Alpha Plus Aminoacid Analyser (Amersham Pharmacia Biotech Europe GMBH, Orsay, França) como descrito por Spackman et al. (1958).

\subsubsection{Compostos voláteis neutros (perfis CG-MS)}

Amostras de queijos foram descongeladas momentos antes das análises e diluídas (1:5) com citrato de sódio (0,5 M pH 8,8). Compostos neutros voláteis foram analisados através de headspace-GC-MS (cromatografia gasosa com detector de massa) como descrito por Thierry et al. (1999). 7,0 g da suspensão foram pesadas em um tubo especial de $35 \mathrm{ml}$ para a entrada da amostra (non-fritted sparger). Rapidamente, os compostos foram imobilizados sobre um Vocarb 3000 trap (Supelco, Bella Fonte, PA), submetido à dessorção térmica a $250^{\circ} \mathrm{C}$, condensado com $\mathrm{N}_{2}$ líquido a $-100^{\circ} \mathrm{C}$ (cryofocused) antes de serem injetados e separados sobre uma coluna capilar HP5 (Agilent Technologies $60 \mathrm{~m}$ x $0.32 \mathrm{~mm} 1 \mu \mathrm{m}$ de espessura de filme). Eles foram detectados por um espectrômetro quádruplo de massa HP7972A (Agilent Technologies) após ionização por impacto eletrônico e identificado por comparação do espectro com aquele da base de dados do Nist $75 \mathrm{~K}$ Mass Spectral e/ou do espectro com o tempo de retenção com aqueles dos compostos de referências. 


\subsection{RESULTADOS}

\subsubsection{Rompimento de células por homogeneização a alta pressão}

A pressão de $200 \mathrm{MPa}$ mostrou-se altamente eficiente para a ruptura de células bacterianas gram-positivas, incluindo lactococos e propionibactéria empregadas neste estudo, sem que as enzimas intracelulares relacionadas com a maturação de queijos fossem completamente desnaturadas (Saboya et al., 2002). Nesse trabalho, as taxas de sobrevivência foram similares àquelas previamente obtidas, $4,6 \%$ para lactococos e 28,8 $\%$ para propionibactéria. Assim, no CBS de lactococos, havia $1,610^{9}$ células $/ \mathrm{ml}$ ainda viáveis $\left(4,6 \%\right.$ do valor inicial), misturadas com o conteúdo intracelular de $3,3 \times 10^{10}$ células rompidas/ml. No caso de $P$. freudenreichii TL 24 , o CBS continha $7,2 \times 10^{9}$ células viáveis/ml, bem como um conteúdo celular referente a $1,75 \times 10^{10}$ de células rompidas/ml.

CBS e CFE exibiram o mesmo perfil de proteínas quando comparados por SDS-PAGE justamente após a homogeneização, indicando que as proteínas solúveis não foram significativamente perdidas durante a etapa da centrifugação para a obtenção de CFE. Portanto, CBS e CFE diferem sobretudo quanto à presença de células viáveis em CBS.

\subsubsection{Composição química dos queijos em D+1}

A composição dos queijos um dia após a fabricação $(D+1)$ foi idêntica para o queijo controle e todos os tratamentos, sendo: pH 5,23 ( $\pm 0,02), 40,4 \%( \pm 0,1)$ em sólidos totais, 16,4\% $( \pm 0,1)$ em gordura, 1,5\% $( \pm 0,04)$ em sal, e 18,9 \% $( \pm 0,5)$ em proteína. A lactose residual era de menos $1 \mathrm{~g} / \mathrm{kg}$ em $\mathrm{D}+1$, devido ao tratamento pela 
diafiltração. Assim, a composição química mostrou-se coerente com os dados da literatura referentes ao queijo-UF Saint Paulin (Goudédranche et al., 1981).

\subsubsection{Populações bacterianas durante a maturação dos queijos}

As populações da cultura láctica acidificante Lactococcus $s p$. foram muito similares em D+1 em todos os queijos (controle e tratamentos), isto é, por volta de 3 $4.0 \times 10^{9} \mathrm{ufc} / \mathrm{g}$ (Figura 13 e Figura 14). Não houve diminuição da viabilidade celular durante o período de maturação; somente um início de queda após a sexta semana. A ausência da lise de lactococos foi confirmada através da análise em Immunoblotting dos extratos aquosos dos queijos preparados semanalmente com um dia de maturação até 45 dias usando anticorpos anti-LC citosol. Nenhuma proteína intracelular foi detectada no queijo controle ou nos tratamentos até dia 27 (Blotting: Anexos C9 e C10); houve um leve indício nas amostras tomadas nos dias 27 e 45 (Figura 13b).
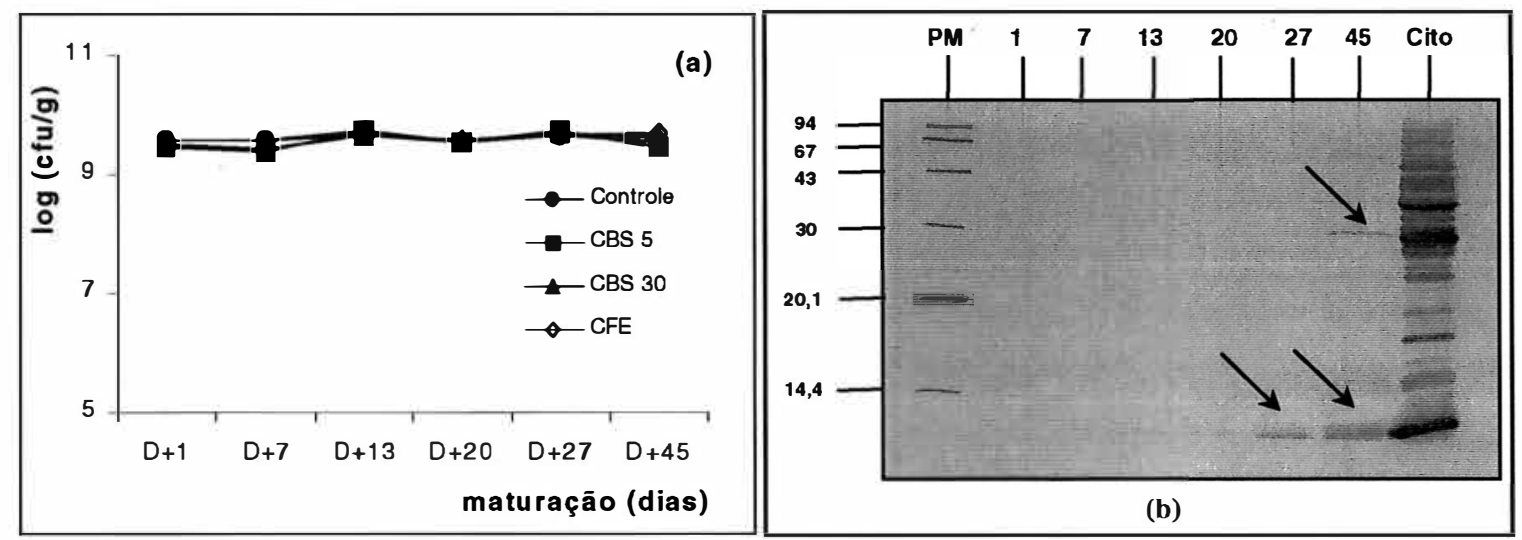

Figura 13 - (a) Contagem do número de células viáveis de Lactococcus sp. em queijosUF a $12^{\circ} \mathrm{C}$ durante a maturação ( Controle; CBS 5; $\triangle \mathrm{CBS} 30$; O CFE). (b) Immunoblotting de proteínas citoplasmáticas de Lactococcus no queijocontrole; o tempo dos queijos, em dias, está indicado acima de cada linha $(\mathrm{PM}=$ Peso Molecular, $\mathrm{kDa} ;$ Cyto = proteínas citoplasmáticas de Lactococcus lactis). 
Nos ensaios adicionando propionibactéria, a população inicial estimada de $P$. freudenreichii era cerca de $10^{7} / \mathrm{g}$ de queijo no tratamento CBS e somente $10^{2} / \mathrm{g}$ de queijo no ensaio com CFE (Figura 14). Não foram notadas modificações nos queijos maturados a $12^{\circ} \mathrm{C}$. Por outro lado, houve um pequeno aumento da população de propionibactéria, de $+1,2$ unidades logarítmicas, quando os queijos passaram a ser incubados a $20^{\circ} \mathrm{C}$ ao invés de $12^{\circ} \mathrm{C}$, no tratamento com CBS (Figura 14b). No queijo controle, propionibactéria não foi detectada em D+1 e menos de $100 \mathrm{ufc} / \mathrm{g}$ ao final da maturação (Figura 14a).

Nos ensaios envolvendo homogeneizados de lactococos, devido ao aditivo ser idêntico à cultura láctica acidificante, não foi possível numerar as células de Lactococcus sp. adicionadas (no tratamento CBS) de forma seletiva. Entretanto, um cálculo teórico pôde ser feito mostrando como todas as células e enzimas adicionadas foram retidas nos retentados de UF: $30 \mathrm{ml}$ de CBS (contendo $1,6 \times 10^{9}$ ufc de lactococos $/ \mathrm{ml}$ ainda viáveis) foram adicionados a $6 \mathrm{~kg}$ de retentado e, assim, teoricamente $6 \times 10^{6}$ células vivas de lactococos foram adicionadas por grama de retentado no tratamento CBS, em paralelo com o conteúdo celular de $1,6 \times 10^{8} / \mathrm{g}$. No tratamento CFE, o conteúdo intracelular também corresponde a $1,6 \times 10^{8} / \mathrm{g}$ foi adicionado, mas sem um número significativo de células vivas.
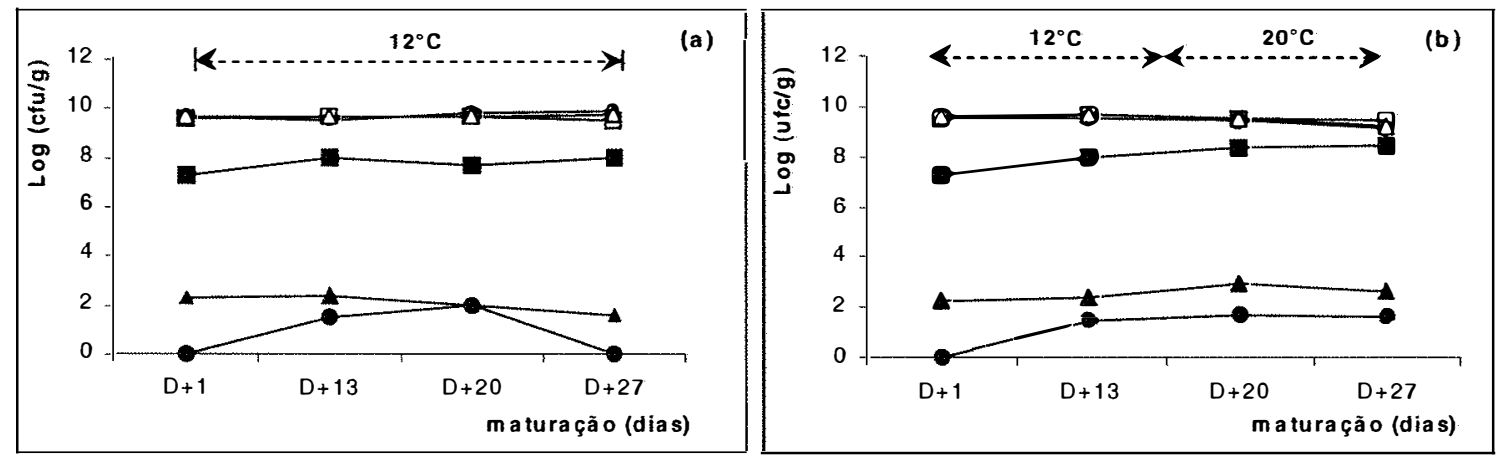

Figura 14 - (a) Contagem do número de células viáveis de Lactococcus sp. (O Controle; CBS; $\triangle \mathrm{CFE}$ ) e P. freudenreichii ( Controle; CBS; $\triangle \mathrm{CFE}) \mathrm{em}$ queijos-UF tratados com $P$. freudenreichii a $12^{\circ} \mathrm{C}$ e (b) a $20^{\circ} \mathrm{C}$ durante o período de maturação. 


\subsubsection{Impacto de homogeneizados de propionibactéria na maturação}

Quando os queijos foram maturados a $12^{\circ} \mathrm{C}$, a evolução do $\mathrm{pH}$ foi a mesma nos tratamentos e no controle, aumentando até o dia 20 de 5,2 a 5,35. Quando os queijos foram maturados a $20^{\circ} \mathrm{C}$, a evolução foi a mesma até o dia 20 quando, então, o valor de $\mathrm{pH}$ continuou a aumentar $(\mathrm{pH}$ 5,45), mas somente no caso dos queijos adicionados de CBS.

Quanto à proteólise, o efeito foi limitado e somente dependente da temperatura de maturação. Quando os queijos foram levados a $20^{\circ} \mathrm{C}$, os índices de NCN/NT (\%) aumentaram cerca de $12 \%$ quando comparados aos queijos a $12{ }^{\circ} \mathrm{C}$, mas não houve aumento suplementar referente à adição de CBS ou CFE (Gráfico: Anexo C11 e SDS-PAGE: Anexo C12). Um pequeno aumento do índice de NPN/NT (\%) foi notado com a adição de CBS ou CFE a 27 dias, comparando-se com o queijo controle, mas somente a $20^{\circ} \mathrm{C}$ (Figura 15$)$.

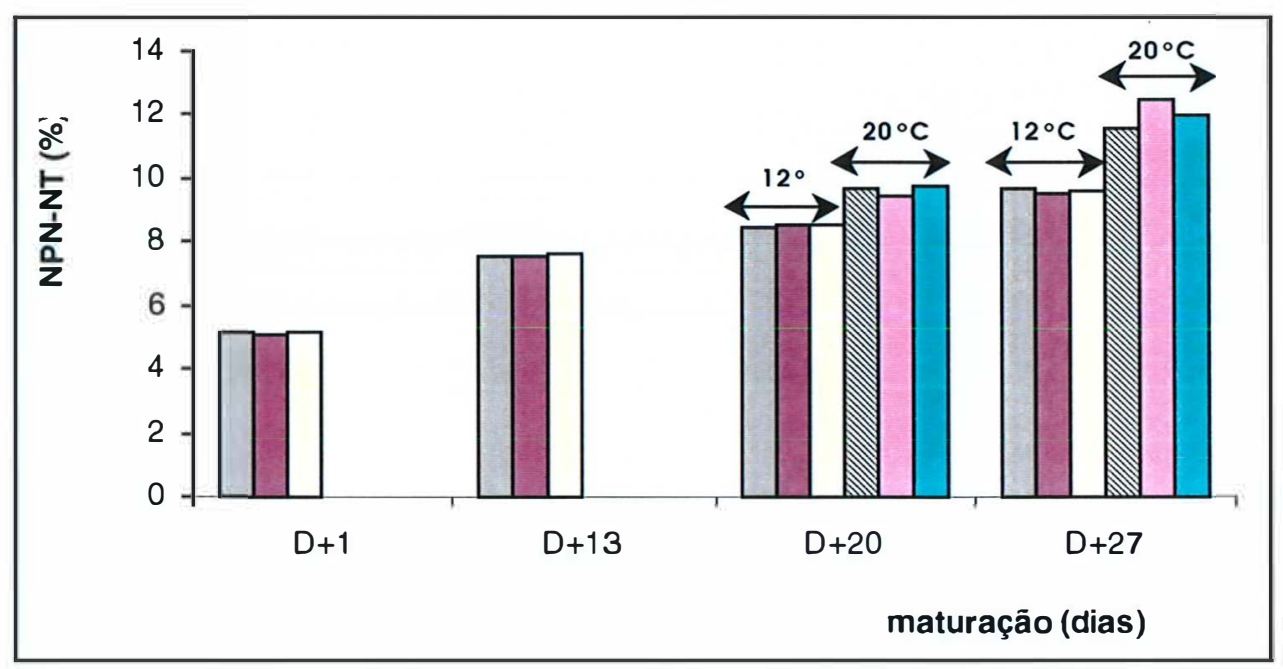

Figura 15- Relações entre NPN e NT (\%) nos queijos-UF tratados com $P$. freudenreichii e maturados a $12^{\circ} \mathrm{C}\left(\square\right.$ Controle; $\square$ CBS; $\square$ CFE) ou a $20^{\circ} \mathrm{C}$ ( Controle; $\square$ CBS; $\square$ CFE). 
A soma dos aminoácidos livres foi de $32,5 \mu \mathrm{M} / \mathrm{g}$ no queijo controle, 32,7 $\mu \mathrm{M} / \mathrm{g}$ e $34 \mu \mathrm{M} / \mathrm{g}$ quando CBS e CFE foram adicionados, respectivamente. O perfil a 27 dias foi altamente similar ao controle, com exceção de algumas pequenas diferenças: na presença de CBS, o conteúdo de Asn, Asp e His diminuiu significativamente, enquanto Glu, Pro, Ala, Leu estavam em quantidades mais elevadas ( de 15 a 40 \%) (Figura 16).

Observando os compostos voláteis neutros de aroma, a análise do queijo controle em CG-MS revelou que havia compostos em quantidades relativamente pequenas (Tabela 2), principalmente álcoois, algumas cetonas e alguns aldeídos. $\mathrm{Na}$ presença de CBS, a quantidade de alguns deles aumentaram ( 2 ou 11 vezes), como 1propanol,1-butanol, 1-pentanol, 3-metil butanol, e 2-metil butanol. Além desses, outros compostos apareceram, principalmente ésteres e compostos sulfúricos como o dimetil dissulfito (Tabela 2). Por outro lado, não foi observado efeito significativo quando CFE foi adicionado em termos de compostos neutros voláteis de aromas, mostrando que a presença de células vivas são necessárias para o aparecimento de compostos aromáticos.

\subsubsection{Impacto de homogeneizados de lactococos na maturação}

O mesmo aumento contínuo dos valores de $\mathrm{pH}$ foi observado até $\mathrm{D}+27$ $(5,2$ a 5,5) para o queijo controle e os queijos adicionados com CBS ou CFE. Não foi observado efeito significativo quanto à proteólise primária, não havendo mudanças nos índices de NCN/NT ou NPN/NT (Gráficos: Anexos C13 e C14). Também, as análises através de SDS-PAGE não mostraram nenhuma diferença quanto ao perfil em proteína (SDS-PAGE: Anexos C15). No entanto, um claro impacto foi constatado com relação aos aminoácidos livres (Figura 16b). As somas dos aminoácidos livres foram de 14,5 $\mu \mathrm{M} / \mathrm{g}$ para o controle, no dia 27 e, respectivamente $20,5,30,6$ e 32,3 $\mu \mathrm{M} / \mathrm{g}$ de queijo com CBS (5 ml), CBS (30 ml) e CFE. Qualitativamente (Figura 16b), a quantidade da maioria dos aminoácidos aumentou 1,5 a 3 vezes quando CFE foi adicionado. $\mathrm{O}$ resultado foi globalmente similar com CBS $(30 \mathrm{ml})$, mas pequenas diferenças foram observadas nos perfis; a adição paralela do conteúdo citoplasmático de células vivas de 
lactococos tiveram uma influência sobre a liberação ou o consumo de alguns aminoácidos.

Tabela 2. Valores das áreas dos compostos voláteis neutros identificados através de CGMS nos queijos tratados com $P$. freudenreichii (CBS e CFE) em D+27 maturados a $20^{\circ} \mathrm{C}$.

\begin{tabular}{|c|c|c|c|c|}
\hline Compostos & Método de & Controle & CBS & CFE \\
\hline Voláteis & Identificação & $\times 10^{6}$ & $\times 10^{6}$ & $\times 10^{6}$ \\
\hline \multicolumn{5}{|l|}{$\overline{\text { Álcoois }}$} \\
\hline 1-propanol & MS & 9 & 174 & 8 \\
\hline 1-butanol & MS & 97 & 242 & 62 \\
\hline 3-metil butanol & $\mathrm{MS} / \mathrm{R}$ & 1.4 & 3,4 & ND \\
\hline 2-metil butanol & $\mathrm{MS} / \mathrm{R}$ & 2.1 & 31,9 & 0.4 \\
\hline 1-pentanol & MS & 2.5 & 5,5 & 1,5 \\
\hline \multicolumn{5}{|l|}{ Aldeídos } \\
\hline 3-metil butanal & $\mathrm{MS} / \mathrm{R}$ & 10.4 & 1.7 & 3.3 \\
\hline \multicolumn{5}{|l|}{ Cetonas } \\
\hline 2,3-butanediona & $\mathrm{MS} / \mathrm{R}$ & 90 & 175 & 103 \\
\hline 2,3-pentanediona & MS & 5 & 4 & 1.2 \\
\hline 2-pentanona & MS & 7.2 & 9.9 & 6.7 \\
\hline 2-hexanona & MS & 0.5 & 2.3 & 0.5 \\
\hline 2-heptanona & $\mathrm{MS} / \mathrm{R}$ & 11.2 & 17 & 10 \\
\hline 2-nonanona & $\mathrm{MS} / \mathrm{R}$ & 1.7 & 2.2 & 1.2 \\
\hline \multicolumn{5}{|l|}{ Ésters } \\
\hline Etil acetato & MS & 3.8 & 4.5 & 1.7 \\
\hline Etil propanoato & MS & ND & 1.2 & ND \\
\hline Etil butanoato & $\mathrm{MS} / \mathrm{R}$ & 3.9 & 3.5 & 3.6 \\
\hline Propil propanoato & MS & ND & 0.9 & ND \\
\hline Propil butanoato & MS & ND & 1.3 & ND \\
\hline Butil butanoato & MS & 0.6 & 0.8 & 0.6 \\
\hline \multicolumn{5}{|c|}{ Compostos Sulfúricos } \\
\hline Dimetil dissulfido & $\mathrm{MS} / \mathrm{R}$ & ND & 2,85 & ND \\
\hline
\end{tabular}

$\mathrm{ND}=$ não detectado

MS = identificado por espectrofotômetro de massa ou comparando-se com banco de dados

MS/R = identificado por espectrofotômetro de massa ou comparando-se com composto de referência 
Esse resultado foi surpreendente visto que a quantidade de células adicionada foi relativamente pequena $\left(6 \times 10^{6}\right.$ células por grama de queijo) comparada ao nível elevado do próprio fermento láctico adicionado $\left(10^{9} / \mathrm{g}\right)$.

Os compostos voláteis neutros de aroma foram estimados em D+27 e também em D+45. Como no ensaio anterior, o queijo controle continha os mesmos poucos compostos aromáticos. Não foi observado nenhum aumento e nem novos compostos quando CFE ou CBS foram adicionados.
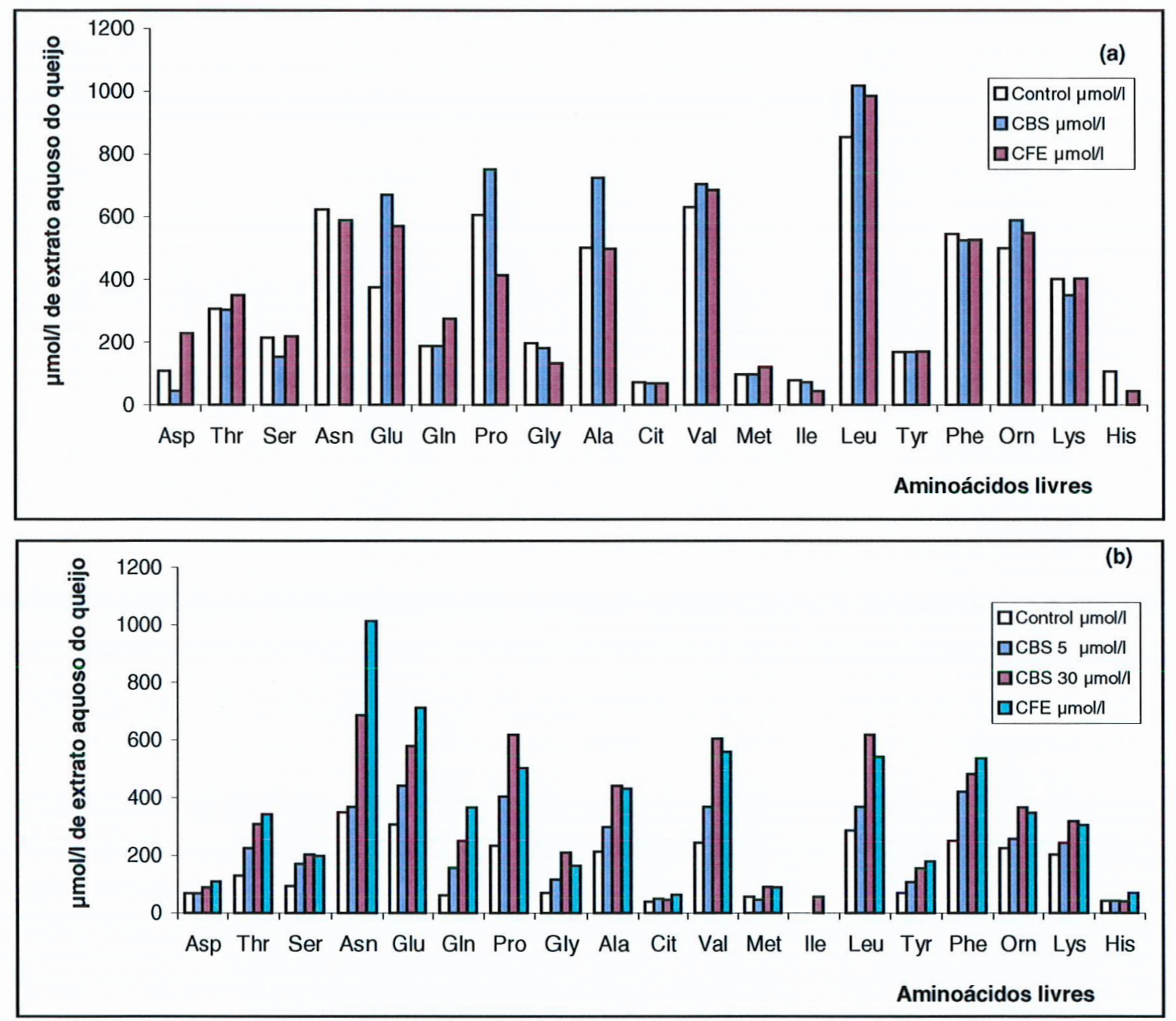

Figura 16 - Composição de aminoácidos livres a D+27 dos queijos-UF Saint Paulin tratados com P. freudenreichii (a) e maturados a $20^{\circ} \mathrm{C}(\square$ Controle; $\square$ CBS; $\square$ CFE) e em queijos-UF Saint Paulin tratado com Lactococcus (b) a 27 após a fabricação e a $12^{\circ} \mathrm{C}$ ( $\square$ Controle; $\square$ CBS 5; $\square$ CBS 30; $\square$ CFE). 


\subsection{Discuss̃̃o}

Tanto a contagem por plaqueamento de células viáveis do fermento láctico adicionado, quanto os resultados do Immunoblotting utilizando marcadores enzimáticos intracelulares específicos, confirmam que em queijos fabricados a partir de leite concentrado por UF em mesmo pH do leite, não há detecção de lise do fermento láctico Lactococcus sp.; essa hipótese já havia sido levantada por Goudédranche et al. (1986) e Mistry \& Maubois (1993). Tal mudança num fenômeno essencial para a maturação de queijos pode estar relacionada às condições do meio, específicas desse tipo de queijo UF, em que se encontra o gênero Lactococcus. A fase aquosa interna dos queijos UF possui um elevado conteúdo em sais de cálcio (Brulé et al., 1974) o que é um fator limitante para a diminuição do $\mathrm{pH}$, induzido pela produção de ácido láctico por Lactococcus, o que, consequentemente pode ser um fator de inibição da lise, como demonstrado para o gênero Lactobacillus (Lortal et al., 1991). Relações entre a lise celular e o poder tampão no interior de queijos UF é uma área de pesquisa que deve ser estudada mais profundamente.

A adição de células rompidas pelo novo homogeneizador-piloto à alta pressão mostra ser um meio interessante para substituir a ausência de lise de lactococos em queijos-UF. Surpreendentemente, a adição de CBS ou CFE de lactococos não aumentou significativamente a taxa de NPN/NT dos queijos durante a maturação, apesar de aumentar significativamente o conteúdo em aminoácidos livres em fatores multiplicados por 1,5 e 3 vezes. Mesmas observações foram feitas por Hyckey et al. (1983) e por Spangler et al. (1989), após a adição respectiva de Lb. helveticus e Lb. helveticus atenuados por choque de congelamento. A estabilidade do conteúdo de NPN pode ser devido à destruição da protease de Lactococcus sp. por ocasião da homogeneização, que é uma hipótese improvável devido aos resultados observados por Saboya et al. (2002) quanto à conservação da atividade da enzima leucinaaminotransferase em lactococos após a homogeneização. Outra hipótese pode ser a inibição dessa enzima por algum componente concentrado por UF, como proposto por 
Bech (1993). As peptidases intracelulares, contrariamente, ainda estão ativas e são capazes de degradar os peptídeos contidos nos queijos UF em aminoácidos livres, como ocorre nos queijos tradicionais (Law \& Wigmore, 1983).

O aumento restrito dos aminoácidos livres observado após a adição de CBS pode estar relacionado ao consumo parcial de aminoácidos formados pelas células viáveis remanescentes $\left(10^{6} \mathrm{ufc/g}\right)$ contidas nessa suspensão.

A adição de CBS ou CFE de Lactococcus sp. aos queijos UF parece não incrementar a formação de compostos voláteis, comparados ao queijo controle. Tal observação confirma o baixo impacto de enzimas intracelulares dessa espécie no desenvolvimento de compostos aromáticos em queijos (Law \& Wigmore, 1983).

O aumento da temperatura de maturação de $12^{\circ} \mathrm{C}$ para $20^{\circ} \mathrm{C}$, verificada nesse estudo quando adicionou-se Propionibacteria CBS ou CFE, permitiu um aumento da proteólise da rede caseínica de $12 \%$, segundo a avaliação através do índice NCN/NT. Este aumento está relacionado com ativação da renina e das proteases das células vivas pela temperatura (Fox, 1993). A maturação a $20^{\circ} \mathrm{C}$ também induziu a degradação de peptídeos, mostrada pelo aumento de $19 \%$ do índice de NPN/NT com relação ao queijo controle. A adição de Propionibacteria CBS no queijo UF resultou em um pequeno aumento na degradação de peptídeos $(+8 \%)$ à temperatura de maturação de $20^{\circ} \mathrm{C}$. Não foi observado impacto significativo com CFE. Como igualmente observado para os experimentos com lactococos, os dados do conteúdo em aminoácidos livres totais não estão de acordo com os resultados da degradação peptídica, mas a identificação de aminoácidos individuais demonstra que o desaparecimento de Asn, provavelmente consumido pelas células vivas remanescentes de propionibactéria no CBS, foi a causa dessa discrepância.

Os dados referentes aos compostos neutros voláteis mostram que não houve diferenças significativas entre o queijo controle e o queijo com CFE de propionibactéria. Por outro lado, a adição de CBS induziu a um claro aumento em vários compostos, incluindo álcoois primários, ésteres, cetonas e dimetil disulfito. 2-metil butanol e 3 metil butanol provavelmente resultaram do respectivo catabolismo dos 
aminoácidos Ile e Leu pelas células de propionibactéria (Thierry \& Maillard, 2002). Os ácidos propiônico e acético que são os principais produtos do metabolismo de propionibactéria, não foram determinados nesse estudo, mas foram provavelmente formados, resultando na formação de ésteres etil e propil de ácido propiônico (Thierry \& Maillard, 2002). Dimetil dissulfito pode ter resultado da degradação de Met por propionibactéria (Thierry \& Maillard, 2002). Ainda, a presença de propionibactéria foi relacionada com a maior quantidade de algumas metil cetonas e de diacetil (2,3butanodiona) formados.

\subsection{CONCLUSÃo}

Este trabalho fornece uma primeira demonstração da ausência de lise do fermento láctico Lactococcus sp. em queijos UF e confirma a baixa extensão da maturação pelas análises da proteólise e de compostos neutros voláteis aromáticos. Por outro lado, demonstrou-se a possibilidade em modificar-se esses dois índices de maturação através da adição de extratos de células bacterianas rompidas por homogeneização à elevada pressão, tecnologia tal que abre uma nova área de investigação para melhorar a maturação de queijos-UF. Outras linhagens e espécies com atividade peptidásica eficiente e habilidade na produção de aromas desejáveis em queijos devem ser agora testadas. 


\section{COMPORTAMENTO DE LACTOCOCOS COM CARACTERÍSTICAS AUTOLÍTICAS DISTINTAS EM QUEIJO MINAS FRESCAL, EMPREGANDO-SE MICROFILTRAÇÃO E ULTRAFILTRAÇÃO}

Luciana Viriato SABOYA', Jean-Yves GASSI ${ }^{2}$, Henri GOUDEDRANCHE ${ }^{2}$, Jean-Louis MAUBOIS ${ }^{2}$, Luiz Eduardo GUTIERREZ', Sylvie LORTAL ${ }^{2}$, Alda Luiza Santos LERAYER ${ }^{3}$

'Escola Superior de Agricultura "Luiz de Queiroz" (ESALQ - USP)

Av. Pádua Dias, 11; Caixa Postal 09; 13418-900, Piracicaba, SP - Brasil.

${ }^{2}$ Laboratoire de Recherches de Technologie Laitière (LRTL - INRA)

65, rue de Saint Brieuc, 35042 Rennes Cedex, France.

${ }^{3}$ Instituto de Tecnologia de Alimentos (ITAL - Tecnolat)

Avenida Brasil, 2880 - 13073-001; Campinas, SP - Brasil

\section{RESUMO}

Estudou-se o comportamento de duas linhagens puras de Lactococcus lactis subsp. cremoris, uma delas lisogênica e altamente autolítica (AM2) e sua variante curada de seu profago, AM2-C, não-autolítica, na fabricação do queijo Minas Frescal, através dos processos tradicional e Ultrafiltração. Empregou-se o leite Microfiltrado (membrana com poros de 1,4 $\mu \mathrm{m}$ ) que, contendo apenas $20 \mathrm{ufc} / \mathrm{ml}$, permitiu avaliar o comportamento dessas linhagens quanto à lise e seus efeitos na proteólise dos queijos, sem a interferência de outras espécies microbianas. Os queijos de todos os tratamentos apresentaram a mesma composição bioquímica após um dia de fabricação. Porém, através da microscopia eletrônica por varredura, pôde-se observar que a microestrutura dos queijos-UF era mais homogênea que a dos queijos obtidos pelo processo tradicional. Quanto à lise das linhagens empregadas, observou-se uma grande diferença entre queijos 
obtidos pelo processo tradicional. A variante curada (AM2-C), mesmo sem apresentar uma elevada taxa de lise, resultou em uma proteólise primária bastante intensa. Ao contrário, a linhagem autolítica (AM2) implicou em uma proteólise primária muito fraca. Parece, portanto, que a lise celular da AM2 afetou a integridade da parede celular e, por conseqüência, a atividade da protease ligada à parede celular de L. cremoris. Nos queijos Minas Frescal obtidos pelo processo de UF, independentemente da linhagem utilizada, detectaram-se apenas fracos sinais de lise em Immunoblotting, levando à conclusão de que ela é praticamente inexistente em tais queijos, quando comparada aos tradicionais. Consequentemente, as proteólises primária e secundária foram similares e pouco intensas, confirmando que a lise de lactococos foi inibida em queijos UF. Os resultados obtidos com queijos Minas Frescal fabricados por UF e com leite desbacterizado através de MF, permitem afirmar que estes queijos evoluem muito pouco durante o período de armazenamento e terão, portanto, uma durabilidade aumentada.

Palavras-chaves: queijo Minas Frescal; autólise; Lactococcus cremoris; Microfiltração, Ultrafiltração, Microscopia Eletrônica.

\section{SUMMARY}

Two single strains of Lactococcus lactis subsp. cremoris were used as starter in traditional or UF Minas Frescal cheesemaking. One strain was known as lysogenic with high autolytic characteristic (AM2). The other one was its prophagecured variant, AM2-C, with non-autolytic property. In order to avoid bias with the natural milk microflora, the cheese milk was previously microfiltered (membrane pore size $1,4 \mu \mathrm{m}$ ). The MF milk containing $20 \mathrm{ufc} / \mathrm{ml}$, did permit evaluate the behavior of both strains in terms of lysis and its effects on the cheese proteolysis was followed. The cheeses made either by traditional process or by ultrafiltration, with the two different starters, showed similar biochemistry composition at day one. On the other hand, scanning electron microscopy showed heterogeneous microstructures in the traditionally processed cheeses contrary to the UF ones that were very homogenous. Autolytic behavior of starters was highly different between the cheeses made by traditional 
technology. The strain prophage-cured (AM2-C) promoted a primary proteolysis very intense in the cheese, contrary to the one made with the strain AM2 where proteolysis was very weak. Our results suggest that cell autolysis of AM2 affected the integrity of cell wall and, consequently, the activity of associated proteases. In the UF-Minas Frescal cheeses, only weak autolysis signs were detected with Immunoblotting, whatever was the used strain. Moreover, primary and secondary proteolysis were low and similar for both strains. These results permited to conclude that lactococci lysis is almost totally inhibited in such cheeses, when compared to the traditional ones. The results concerning the Minas Frescal cheeses made from microfiltered and UF milk allows affirming that these cheeses maintain their characteristics during the storage period and they will have, therefore, a higher shelf life.

Key words: Minas Frescal cheese; lysis; Lactococcus cremoris; Microfiltration; Ultrafiltration; Electronic Microscopy.

\subsection{INTRODUÇÃO}

O Minas Frescal é o terceiro queijo mais comercializado no Brasil, possuindo, portanto, uma expressiva importância econômica. É um queijo fresco, de massa mole, com uma vida de prateleira muito restrita, de cerca de 10 dias (WolfschoonPombo et al., 1984; Furtado, 1999). Sua tecnologia tradicional de fabricação foi desenvolvida em pequenas propriedades no Estado de Minas Gerais e difundiu-se por todo o território nacional devido à sua elevada aceitabilidade e alto rendimento. No início dos anos 80, foi sugerido por Vieira et al. (1983) a fabricação do Minas Frescal através de um processo alternativo, o MMV (Maubois et al., 1969) que confere maior rendimento de fabricação e maior durabilidade ao produto (Van Dender et al., 1999). Embora o queijo obtido por Ultrafiltração seja distinto daquele obtido pela tecnologia tradicional, ele alcançou grande expressividade no comércio e, atualmente, os dois tipos encontram espaço considerável no mercado brasileiro de queijos. 
Queijos frescos possuem durabilidade muito restrita devido à elevada umidade do produto, às contaminações microbiológicas durante o processo de fabricação e às oscilações de temperatura que geralmente ocorrem entre a indústria e os pontos de comercialização (Wolfschoon-Pombo et al., 1984; Furtado \& Lourenço-Neto, 1994). Vários estudos já foram conduzidos com o intuito de aumentar a durabilidade do Minas Frescal e minimizar o desenvolvimento de microrganismos contaminantes (WolfschoonPombo et al., 1978; Moreno et al., 1998). A maioria das pesquisas ressalta a importância da qualidade microbiológica da matéria-prima, o leite, e do adequado condicionamento do queijo como requisitos fundamentais para obtenção de um produto de melhor qualidade.

Uma elevada taxa de proteólise, resultante principalmente da ação de peptidases liberadas pela lise do fermento láctico, é uma qualidade almejada para a maioria das variedades de queijos maturados, pois resultará numa consistência macia e na produção de aroma mais pronunciado (Chapot-Chartier et al., 1994; Wilkinson et al., 1994). No entanto, no caso do queijo Minas Frescal, uma proteólise avançada, caracterizada por cor amarelada da casca e consistência mole, são atributos negativos de sua qualidade (Wolfschoon-Pombo et al., 1984). O Minas Frescal, por ser um queijo fresco, é consumido sem maturação; porém, a tecnologia de fabricação e, consequentemente, a proteólise, influenciam decisivamente sua consistência, sabor e durabilidade (Wolfschoon-Pombo, 1983; Wolfschoon-Pombo \& Lima, 1989).

Considerando tais particularidades do Minas Frescal e a fim de diminuir um processo proteolítico intenso durante a sua conservação, esse trabalho teve como objetivo verificar se a utilização de linhagens de lactococos com características autolíticas distintas (Lactococcus lactis subsp. cremoris AM2, autolítica e sua variante curada L. lactis subsp. cremoris AM2-C, não-autolítica), poderia influenciar a durabilidade desse queijo, fabricado por tecnologia tradicional ou através de Ultrafiltração (processo MMV). O emprego do leite microfiltrado para a produção dos queijos teve por objetivo reduzir enormemente a sua carga microbiana, de forma a não haver influência de qualquer outro microrganismo que não fossem as linhagens adicionadas (Saboya \& Maubois, 2000). 
O comportamento dessas culturas lácticas durante o armazenamento do queijo Minas Frescal (tradicional e Ultrafiltrado) foi estudado analisando-se suas propriedades autolíticas através de 1) estimativa da viabilidade celular; 2) microscopia eletrônica por varredura e 3) detecção de enzimas intracelulares por Immunoblotting. O impacto dessas linhagens na proteólise e na conservação dos queijos foi avaliado medindo-se as frações nitrogenadas protéicas, expressas como índices de proteólise (NCN/NT e NPN/NT) e através de eletroforese (SDS-PAGE). Os queijos tradicionais também foram avaliados por HPLC em D+1 e D+14.

\subsection{Material E MÉTODOS}

\subsubsection{Origem e cultivo das linhagens}

L. lactis subsp. cremoris AM2 foi obtida da coleção do CNRZ (INRA, Jouy-en-Josas, França). A linhagem AM2-C, derivada da linhagem AM2, curada de seu profago (Ø AM2) por Lepeuple et al. (1997), foi gentilmente cedida por Chapot-Chartier (CNRZ, Jouy-en-Josas, França). As linhagens foram estocadas em leite desnatado reconstituído e congeladas a $-18^{\circ} \mathrm{C}$ até sua utilização, quando foram ativadas duas vezes em leite desnatado e esterilizado, antes de serem adicionadas ao leite de fabricação.

\subsubsection{Fabricação dos queijos}

\subsubsection{Microfiltração do leite}

A Microfiltração do leite foi realizada em uma unidade piloto GP 7 (Tetra-Laval, Aahus, Dinamarca) equipado com 1,68 $\mathrm{m}^{2}$ de membranas GP Membralox ${ }^{\circledR}$ GP (Société des Céramiques Techniques, Bazet, França) com tamanho médio de poro de 
1,4 $\mu \mathrm{m}$ (Foto: Anexo A1). O leite desnatado foi aquecido a $50^{\circ} \mathrm{C}$ e circulado a alta velocidade de $7,5 \mathrm{~m} / \mathrm{s}$, sendo o valor da pressão uniforme entre membranas (UTP) de cerca de 0,5 bars.

O leite desnatado microfiltrado foi padronizado a 3,5\% em matéria graxa $(\mathrm{p} / \mathrm{p})$, resfriado a $30^{\circ} \mathrm{C}$ e os dois processos de fabricação (tradicional e Ultrafiltração) foram conduzidos paralelamente, partindo-se do mesmo lote de leite, como ilustra a Figura 17, resultando em 4 tratamentos:

a) queijo Minas Frescal tradicional, fabricado com a linhagem L. lactis subsp. cremoris AM2 (autolítica), identificado como Trad AM2;

b) queijo Minas Frescal tradicional fabricado com a linhagem L. lactis subsp. cremoris AM2-curada (não-autolítica), identificado como Trad AM2-C;

c) queijo Minas Frescal, fabricado com leite ultrafiltrado e com a linhagem L. lactis subsp. cremoris AM2 (autolítica), identificado como UF AM2;

d) queijo Minas Frescal, fabricado com leite ultrafiltrado e com a linhagem L. lactis subsp. cremoris AM2-curada (não-autolítica), identificado como UF AM2-C

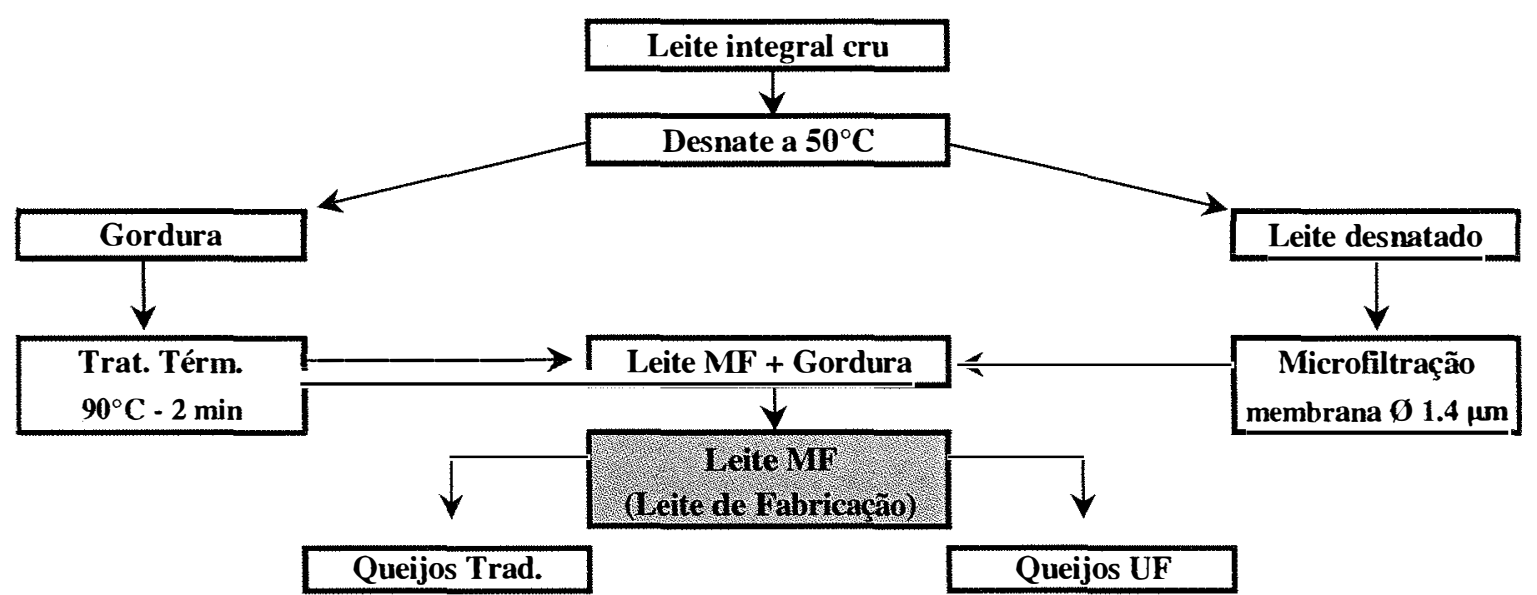

Figura 17 - Esquema de obtenção do leite microfiltrado (MF) para a fabricação do queijo Minas Frescal pelo processo tradicional e por Ultrafiltração. 


\subsubsection{Fabricação dos queijos tradicionais}

O queijo Minas Frescal tradicional foi fabricado num equipamento piloto semi-automático adaptado para a fabricação de queijos do tipo massa mole (Tecnal, Niort, França) (Foto: Anexo D1), empregando-se $40 \mathrm{~kg}$ de leite Microfiltrado para cada experimento, de acordo com o procedimento abaixo descrito. As duas fabricações foram conduzidas ao mesmo tempo, tendo como variante somente a linhagem de lactococos $(L$. lactis subsp. cremoris AM2 ou AM2-C).

A cultura láctica foi adicionada ao leite a $35^{\circ} \mathrm{C}$, temperatura esta mantida durante toda a fabricação. O fermento láctico foi adicionado a $1 \%$ ao leite e a préacidificação foi realizada durante 30 minutos. Adicionaram-se $12 \mathrm{ml}$ de coalho (520 mg/l de quimosina, Granday, França) em cada cuba de fabricação (40 kg de leite).

Após 3 vezes o tempo do início da formação da coalhada, cortou-se a massa em cubos de $3 \mathrm{~cm}^{2}$ (Foto: Anexo D2) e, após 5 minutos, iniciou-se a agitação intermitente a cada 3 minutos durante 15 minutos (Foto: Anexo D3). Seguiu-se, então, uma agitação rápida por mais 15 minutos. Adicionou-se o sal a 3,5\% (p/p) à mistura massa/soro. A massa foi vertida em formas de $500 \mathrm{~g}$ (Foto: Anexo D4). Os queijos foram virados 3 vezes a cada meia hora, seguindo-se da estocagem em câmara a $5^{\circ} \mathrm{C}$.

\subsubsection{Ultrafiltração e fabricação de queijos-UF}

Após a MF e a padronização do leite, iniciou-se o processo de Ultrafiltração usando um equipamento de Ultrafiltração-piloto com membranas CARBOSEP Ml (membrana com poder de corte de $150 \mathrm{kDa}$ e superfície de $6,8 \mathrm{~m}^{2}$ Société Orelis, França) durante 80 minutos (Foto: Anexo C3). A temperatura durante o processo de UF foi mantida entre $48-50^{\circ} \mathrm{C}$. A fabricação do queijo Minas Frescal por UF foi realizada segundo o protocolo de Vieira et al. (1983).

Fez-se uma diluição do retentado (1,12 v/v) quando este encontrava-se $\operatorname{com} \mathrm{fc}=3$, adicionando-se água destilada a $50^{\circ} \mathrm{C}$. Deu-se continuidade à UF até obter-se um retentado com fator de concentração final igual a 5. Este foi imediatamente resfriado a $32^{\circ} \mathrm{C}$ e dividido em 2 partes de $10 \mathrm{~kg}$ (Foto: Anexo D7). Cada parcela foi inoculada 
com $4 \%$, das culturas lácticas: L. lactis subsp. cremoris AM2 ou AM2-C (de modo a obter-se $10^{7} \mathrm{ufc} / \mathrm{ml}$ de retentado). A fermentação foi realizada durante 3 horas a $30^{\circ} \mathrm{C}$, até o pH atingir valor próximo de 6,5, quando adicionaram-se 1,6\% (p/v) de $\mathrm{NaCl}$ e $20 \mathrm{ml}$ de coalho por $100 \mathrm{~kg}$ de retentado, agitando-se vigorosamente. Seguiu-se a enformagem em potes plásticos (200 g) (Foto: Anexo D8), os quais foram mantidos a $30^{\circ} \mathrm{C}$ por mais 1:45h para o endurecimento do retentado, sendo, em seguida, levados à câmara fria, a $5^{\circ} \mathrm{C}$.

\subsubsection{Análises físico-químicas do leite e retentado}

O leite de fabricação, os soros referentes aos queijos tradicionais e o retentado (pré-queijo) obtido após a Ultrafiltração $(\mathrm{fc}=5)$ foram analisados quanto ao pH, extrato seco, gordura, proteína total, nitrogênio-não-caseínico, nitrogênio-nãoprotéico, segundo as normas e métodos oficiais descritos em 5.2.4.

\subsubsection{Análises físico-químicas dos queijos}

As amostras dos queijos foram tomadas após 1, 7, 14 e 21 dias de fabricação. Em D+1, realizaram-se as seguintes análises no queijo: pH, extrato seco, gordura, proteína total, nitrogênio-não-caseínico, nitrogênio-não-protéico, sal e cinzas. O valor do $\mathrm{pH}$ foi obtido através de um pontenciômetro padrão CG837 com eletrodos InLAB 427 (Mettler Toledo, França) através da introdução direta do eletrodo no queijo. O Extrato Seco Total (EST) foi estimado através da secagem das amostras de queijos em cápsulas de alumínio a $102^{\circ} \mathrm{C}( \pm 2)$ durante 7 horas (International Dairy Federation IDF, 1982). O teor em gordura foi determinado usando o método de Van Gulik (Federation Internationale de Laiterie - FIL, 1997). O teor de sal foi analisado usando o aparelho "Chloruremetre Corning 926" (Humeau Laboratoires, França). As cinzas foram determinadas segundo a Association Française de Normalisation (AFNOR, 1989). Os valores de nitrogênio total (NT) foram obtidos a partir da análise do nitrogênio pelo 
método de Kjeldahl, usando um aparelho automático (Técator), sendo o valor de conversão 6,38, de acordo com as normas da IDF (1962).

A proteólise dos queijos foi avaliada durante 4 semanas, por meio das análises do nitrogênio solúvel em pH 4,6 (ou nitrogênio-não-caseínico ou NCN) e do nitrogênio solúvel em TCA a 12 \% (nitrogênio-não-protéico ou NPN), de acordo com Gripon et al. (1975). Os resultados foram expressos em porcentagem do nitrogênio total no queijo.

\subsubsection{Análises microbiológicas do leite, soro e retentado}

O número de células viáveis totais do leite cru desnatado, do leite microfiltrado e do leite microfiltrado padronizado com gordura pasteurizada (leite de fabricação) foi estimado pelo método de semeadura em profundidade, com incubação a $30^{\circ} \mathrm{C}$ durante 48 horas em meio de cultura PCA (Plate Count Agar) (FIL, 1991). Para estimar o número de células de Lactococcus sp. semeadas no leite de fabricação (queijo tradicional) e no retentado (queijo ultrafiltrado), bem como as células resultantes no soro produzido pela fabricação tradicional, utilizou-se o meio de cultura BHI adicionado de $1,1 \%$ de ágar (AFNOR, 1984). As placas semeadas em profundidade foram incubadas a $30^{\circ} \mathrm{C}$ durante 72 horas. Os resultados foram expressos como logaritmo (log) de unidades formadoras de colônia (ufc) por mililitro de amostra.

\subsubsection{Análises microbiológicas dos queijos}

Amostras de queijos (10 g) foram tomadas assepticamente a cada sete dias durante 3 semanas de estocagem e diluídas em $90 \mathrm{~g}$ de citrato tri-sódico (20 g/l ). A homogeneização das amostras foi feita usando o aparelho Waring Blendor (Prolabo, F94126 Fontenay-sous-Bois, França), inicialmente sob baixa velocidade por 20 segundos, e a seguir, sob alta velocidade por 40 segundos. Diluições decimais foram preparadas a partir dessa suspensão. A viabilidade de Lactococcus lactis subsp. cremoris foi 
determinada através da técnica de semeadura em meio BHI ágar, como anteriormente descrito.

\subsubsection{Extrato aquoso do queijo}

Extratos aquosos de queijos foram obtidos tomando-se amostras de 5,0 g de queijo, diluídas em $20 \mathrm{ml}$ de água destilada estéril e homogeneizadas manualmente em sacos plásticos estéreis com filtros (Humeau, França). As soluções foram recolhidas e centrifugadas a $10.000 \mathrm{~g}$ e a $4^{\circ} \mathrm{C}$ por 15 minutos. Os sobrenadantes, isto é, os extratos aquosos dos queijos, foram filtrados em membranas com poros de 0,45 $\mu \mathrm{m}$ (Sartorius, F91127 Palaiseau, França) e mantidos a $-18^{\circ} \mathrm{C}$ até sua utilização.

\subsubsection{Análises em SDS-PAGE}

As proteínas presentes nos extratos aquosos dos queijos foram analisadas em géis de poliacrilamida em condições desnaturantes (SDS-PAGE), como descrito por Valence \& Lortal (1995). As amostras foram misturadas (v/v) em tampão Laemmli (1971) e adicionadas no gel (a $14 \%$ de separação). A migração foi realizada a $25^{\circ} \mathrm{C}$ sob voltagem constante de $180 \mathrm{~V}$ por $1: 30 \mathrm{~h}$.

\subsubsection{Autólise da cultura láctica}

A autólise da cultura láctica Lactococcus sp. foi monitorada durante a conservação dos queijos usando-se anticorpos produzidos contra extratos intracelulares de L. cremoris (denominados LC-citosol), obtidos por Valence (1999). Os extratos aquosos dos queijos foram analisados em SDS-PAGE seguido-se a transferência através de Western-Blotting $(1: 15 \mathrm{~h}$, corrente constante de $250 \mathrm{~mA})$ em uma folha de nitrocelulose (poros de 0,45 $\mu \mathrm{m}$, Millipore, F-78051 St Quentin en Yvelines, França). As proteínas citossólicas de L. cremoris foram detectadas com soro anti-LC-citosol 
(estocadas a $-30^{\circ} \mathrm{C}$ e diluídas a $1 / 2500$ em PBS-Tween, imediatamente antes da sua utilização. $\mathrm{O}$ anticorpo Horseradish peroxidase-conjugated goat anti-rabbit $\operatorname{IgG}(\mathrm{H}+\mathrm{L})$ HRP conjugate (Biorad) foi usado como um anti-soro secundário com DAB (3,3'diaminobenzidina tetrahidroclorina) (Amresco, Solon, USA) como revelador (Valence et al., 1998).

\subsubsection{Microscopia eletrônica por varredura}

Amostras de queijos tradicionais e UF foram tomadas após dois dias de armazenamento a $5^{\circ} \mathrm{C}$. Três fatias de $1 \times 1 \times 3 \mathrm{~mm}$ foram cortadas a partir da porção interna do queijo e incubadas em solução de glutaraldeído à 2,5\% em tampão cacodilato de sódio $(0,1 \mathrm{M}, \mathrm{pH} 7,2)$ a $4^{\circ} \mathrm{C}$ por, no mínimo, 20 horas.

Essas amostras foram lavadas em tampão cacodilato de sódio $(0,1 \mathrm{M}, \mathrm{pH}$ 7,2), seguindo-se de mais duas lavagens em água destilada estéril e de desidratação em álcool a concentrações variadas de 10,25, 50, 75, 95 e $100 \%$, sucessivamente. As amostras foram secas em $\mathrm{CO}_{2}$, montadas sobre uma pequena saliência de alumínio sob uma plaqueta e revestidas com $15 \mathrm{~nm}$ de ouro. A análise microscópica foi realizada utilizando-se um Microscópio Eletrônico Philips WL20 sob voltagem de 15 KV.

\subsubsection{Análises de peptídeos em HPLC}

Os peptídeos contidos nos extratos aquosos de queijos Minas Frescal (Trad AM2 e Trad AM2-C) em D+1 e D+14, foram separados por HPLC em um sistema Sep-Pak ${ }^{\circledR}$ Vac C18 (Waters, Milford, MA, USA). As amostras foram recuperadas em $650 \mu 1,(600 \mu l$ de água MilliQ + TFA 0,2\% + $50 \mu 1$ de acetonitrila). Foram injetados 50 $\mu \mathrm{l}$ ou $100 \mu \mathrm{l}$ em uma colônia Symmetry C $18\left(2,1 \times 150,40^{\circ} \mathrm{C}, 0,250 \mathrm{ml} / \mathrm{min}\right.$, Waters, Saint Quentin en Yvelines, França) com um gradiente linear de 4 a $48 \%$ de acetonitrila em 60 minutos. Os picos eluídos foram detectados a 214 e a $280 \mathrm{~nm}$. 


\subsection{RESUltados}

\subsubsection{Análises microbiológicas do leite, soro e retentado}

Através das análises do leite (microfiltrado e cru), pudemos comprovar a eficiência de retirada de microrganismos através da Microfiltração, que nesse caso foi de 99,98\%, ou seja, o leite cru desnatado possuía 1,8 × $10^{4} \mathrm{ufc} / \mathrm{ml}$ e, após a MF, passou a uma carga total de apenas $03 \mathrm{ufc} / \mathrm{ml}$, estando de acordo com dados encontrados por Madec et al. (1992). A reincorporação de gordura pasteurizada aumentou ligeiramente a contagem total de microrganismos do leite de fabricação ( $20 \mathrm{ufc} / \mathrm{ml}$ ), podendo-se ainda considerá-lo com carga bacteriana muito baixa. Após a UF, obteve-se uma contagem total de mesófilos de $3,1 \times 10^{2} \mathrm{ufc} / \mathrm{ml}$ de retentado.

A contagem de mesófilos no leite de fabricação após a inoculação com as

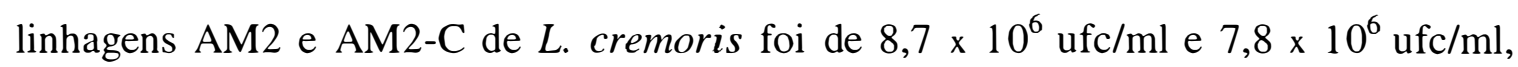
respectivamente. Os lotes de retentado destinados à fabricação dos queijos UF, foram inoculados com uma quantidade um pouco superior de células, sendo $3,0 \times 10^{7} \mathrm{ufc} / \mathrm{ml}$ de AM2 e 3,53 x $10^{7} \mathrm{ufc} / \mathrm{ml}$ de AM2-C.

A quantidade de células resultantes no soro de fabricação dos queijos tradicionais foi de $1,5 \times 10^{5} \mathrm{ufc} / \mathrm{ml}$ de soro, no tratamento em que se adicionou a linhagem de lactococos autolítica (Trad AM2) e de 3,2 × $10^{5} \mathrm{ufc} / \mathrm{ml}$ de soro, no tratamento com a linhagem curada, não-autolítica (Trad AM2-C).

\subsubsection{Evolução do pH durante a fabricação dos queijos}

Os leites de fabricação destinados aos queijos tradicionais foram inoculados com as respectivas linhagens de $L$. cremoris (AM2 e AM2-C) a pH 6,60, sendo realizada uma pré-maturação de 30 minutos, com pH mantendo-se constante 
durante esse período. Toda a acidificação ocorreu de forma similar para ambos os tratamentos. Ao final da mexedura da mistura massa/soro, o $\mathrm{pH}$ encontrava-se a 6,5 e no momento da enformagem, por volta de 6,4. Ao final da terceira viragem, quando os queijos foram levados para a câmara fria, o pH era de 6,2.

Nos queijos-UF, o pH do retentado ao final do processo foi de 6,66. O retentado obtido foi resfriado a $30^{\circ} \mathrm{C}$ e inoculado com as culturas lácticas. A acidificação pelas duas linhagens também ocorreu de forma similar nos dois tratamentos (UF AM2 e UF AM2-C) e ao final da maturação, após 3 horas a $30^{\circ} \mathrm{C}$, o $\mathrm{pH}$ dos pré-queijos era de 6,57 e 6,55 nos tratamentos UFAM2 e UF AM2-C, respectivamente.

\subsubsection{Composição físico-química dos queijos em D+1}

Os dados da composição físico-química em $\mathrm{D}+1$ dos queijos Minas Frescal tradicional e UF são encontrados na Tabela 3. Esses valores são todos condizentes a dados encontrados na literatura (Wolfschoon-Pombo et al., 1978; Vieira et al., 1983; Saboya et al., 1998; Van Dender et al., 1999).

Tabela 3. Composição físico-química dos queijos Minas Frescal fabricados pelo processo tradicional e por UF um dia após a fabricação.

\begin{tabular}{ccccccccccc}
\hline Tratamentos & $\mathbf{p H}$ & $\begin{array}{c}\text { EST } \\
(\boldsymbol{\%})\end{array}$ & $\begin{array}{c}\text { Gordura } \\
(\boldsymbol{\%})\end{array}$ & $\begin{array}{c}\text { UESD } \\
(\boldsymbol{\%})\end{array}$ & $\begin{array}{c}\text { Proteína } \\
(\boldsymbol{\%})\end{array}$ & $\begin{array}{c}\text { NT } \\
(\boldsymbol{\%})\end{array}$ & $\begin{array}{c}\text { NCN/NT } \\
(\boldsymbol{\%})\end{array}$ & $\begin{array}{c}\text { NPN/NT } \\
(\boldsymbol{\%})\end{array}$ & $\begin{array}{c}\text { Sal } \\
(\boldsymbol{\%})\end{array}$ & $\begin{array}{c}\text { Cinzas } \\
(\boldsymbol{\%})\end{array}$ \\
\hline Trad AM2 & 6,2 & 34,2 & 14,9 & 77,4 & 13,5 & 2,1 & 7,1 & 2,9 & 1,0 & 2,4 \\
Trad AM2-C & 5,4 & 34,8 & 14,9 & 76,7 & 13,9 & 2,2 & 7,7 & 2,8 & 1,1 & 2,6 \\
\hline UF AM2 & 6,1 & 34,9 & 16,4 & 77,8 & 14,8 & 2,3 & 13,1 & 3,2 & 1,6 & 3,1 \\
UF AM2-C & 6,0 & 35,8 & 16,2 & 76,7 & 14,7 & 2,3 & 14,1 & 3,4 & 1,6 & 3,1 \\
\hline
\end{tabular}

Os dois processos de fabricação resultaram em queijos com composição centesimal distinta em proteína, gordura, cinzas e nas relações de NCN/NT e NPN/NT, explicadas pelo próprio processo de UF, que possibilita uma maior concentração desses componentes, proporcionando, assim, melhor rendimento de fabricação. Porém, quando 
comparados dois a dois (dentro do mesmo processo de fabricação), esses valores foram bastante similares (Tabela 3). O teor de sal também diferiu entre os dois processos de fabricação devido ao modo distinto de salga efetuado. Porém, os queijos dos quatro tratamentos apresentaram extrato seco total (EST) similares e valores de umidade no extrato seco desengordurado (UESD) muito próximos, indicando que todos os queijos possuem consistência semelhantes e mesmas condições para ocorrência de reações, principalmente a proteólise, durante o período de armazenamento. Esses valores estão de acordo com os valores encontrados por Vieira et al. (1983) e Van Dender et al. (1999) quando estudaram o queijo Minas Frescal UF e o compararam à tecnologia de fabricação tradicional.

Surpreendentemente, os valores de $\mathrm{pH}$ dos queijos fabricados pelo processo tradicional estavam bastante distintos entre si em $\mathrm{D}+1$, tendo-se observado valor de 6,2 para o tratamento Trad AM2 e 5,4 para o queijo Trad AM2-C. Porém, o mesmo não foi observado para os queijos fabricados pelo processo de UF, onde os valores de $\mathrm{pH}$ eram similares para os dois tratamentos $(6,1$ e 6,0$)$.

\subsubsection{Evolução do pH}

As curvas mostrando as evoluções dos valores de $\mathrm{pH}$ durante o armazenamento dos queijos Minas Frescal fabricados pelos processos tradicional e por UF, encontram-se na Figura 18.

Os valores do $\mathrm{pH}$ do queijo tradicional fabricado com a linhagem autolítica (Trad AM2), mantiveram-se bastante estáveis, ao redor de 6,0, durante todo o período de armazenamento a $5^{\circ} \mathrm{C}$ (Figura 18). No caso do queijo fabricado com a linhagem não-autolítica (Trad AM2-C), a evolução do pH ocorreu diferentemente, havendo um pequeno decréscimo, de 5,4 no início, até 4,9 em D+21. Ao contrário, a evolução do $\mathrm{pH}$ dos dois queijos-UF ocorreu de forma bastante similar entre os dois tratamentos, independente da característica autolítica da linhagem. Observou-se um 
pequeno decréscimo nos valores de $\mathrm{pH}$ desses queijos até $\mathrm{D}+7$, mantendo-se constante durante todo o período de armazenamento, como mostra a Figura 18.

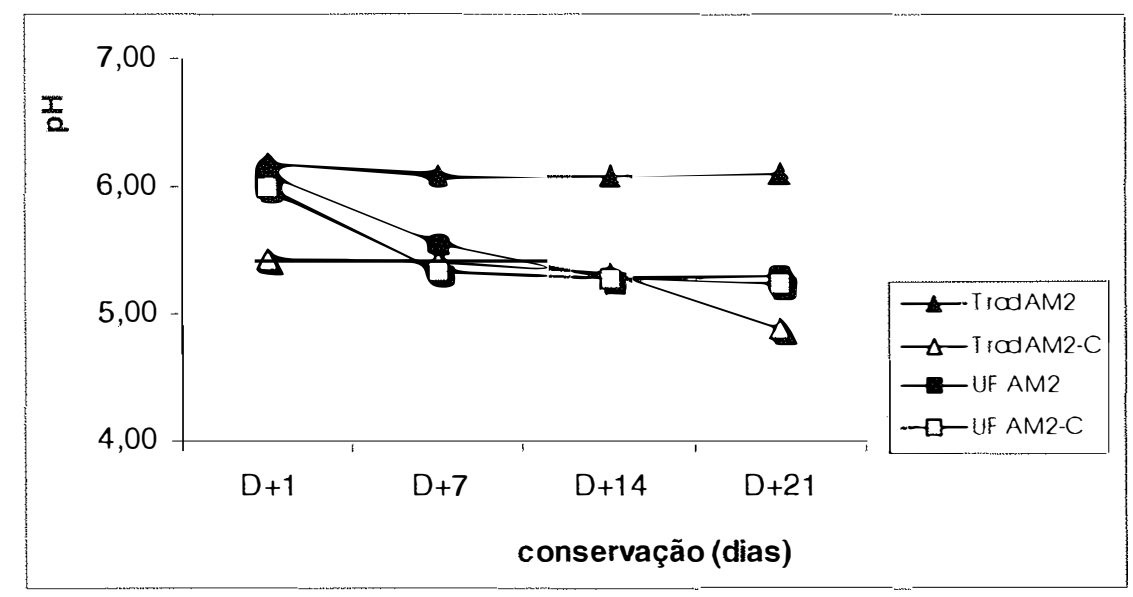

Figura 18 - Evolução do pH dos queijos Minas Frescal, fabricados com a linhagem $L$. lactis subsp. cremoris AM2, através de tecnologias tradicional ( $\mathbf{A}$ ) ou Ultrafiltração ( $\mathbf{\square}$ ), ou com L. lactis subsp. cremoris AM2-C e tecnologias tradicional $(\triangle)$ ou Ultrafiltração $(\square)$,durante a estocagem a $5^{\circ} \mathrm{C}$ por 4 semanas.

\subsubsection{Comportamento autolítico da flora microbiana}

O comportamento autolítico das duas linhagens de L. cremoris (AM2 e AM2-C) durante o período de armazenamento a $5^{\circ} \mathrm{C}$ dos queijos Minas Frescal, fabricados pelos processos tradicional e UF, foi avaliado através de 3 parâmetros, separadamente, quais sejam, 1) estimativa da viabilidade celular através de plaqueamento; 2) detecção da liberação de enzimas intracelulares específicas por Immunoblotting e 3) observação da conformação celular das bactérias através de microscopia eletrônica por varredura. 


\subsubsection{Viabilidade de lactococos nos queijos}

As curvas de viabilidade de Lactococcus sp. durante o período de armazenamento dos queijos estão apresentadas na Figura 19.

Foi estimada uma contagem de células viáveis bastante reduzida $(5,93$ $\log$ ) no queijo Trad AM2 em D+1, com relação ao tratamento Trad AM2-C (7,88 log), o que é uma diferença significativa, sendo que os níveis de inóculo no leite dessas culturas foram similares. Constatou-se, ainda, nesse tratamento (Trad AM2), uma diminuição contínua de viabilidade até D+7 (4,60 log). Houve, porém, um aumento progressivo do número de células viáveis em D+14 (5,30 log) e D+2 1 (6,39 log) (Figura 19). O mesmo não foi observado no tratamento Trad AM2-C, onde o número de células viáveis permaneceu constante.

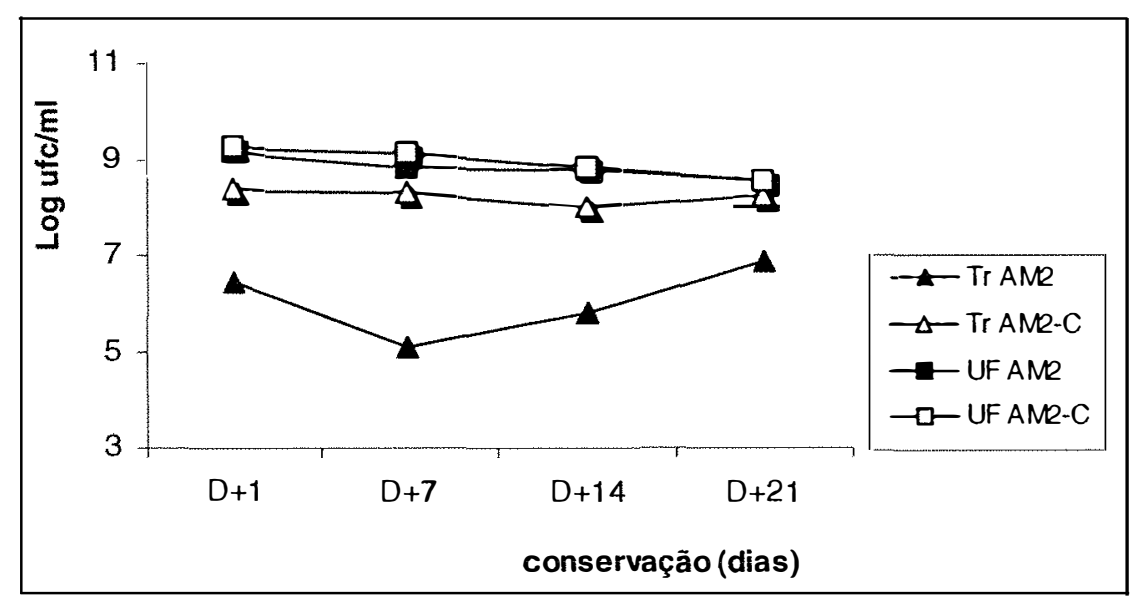

Figura 19 - Viabilidade da população de bactérias dos queijos Minas Frescal fabricados com L. lactis subsp. cremoris AM2 através de tecnologias tradicional ( $\mathbf{\Delta}$ ) ou Ultrafiltração ( $\mathbf{\square})$ ou com L. lactis subsp. cremoris AM2-C, e tecnologias tradicional $(\Delta)$ ou Ultrafiltração $(\square)$, durante o armazenamento do queijo Minas Frescal a $5^{\circ} \mathrm{C}$ por 4 semanas.

Surpreendentemente, a mesma linhagem autolítica no queijo fabricado por UF (UF AM2), apresentou uma queda de viabilidade ínfima, de apenas de 8,62 log em D+1 para 8,08 log em D+21. Na verdade, tanto a linhagem autolítica como a não- 
autolítica comportaram-se de maneira semelhante nos dois queijos-UF, ao contrário dos queijos tradicionais.

\subsubsection{Verificação da lise de Lactococcus nos queijos através de Immunoblotting}

Os resultados das análises de Immunoblotting para detectar a presença de enzimas intracelulares de Lactococcus sp. nos extratos aquosos dos queijos, estão mostrados na Figura 20. As enzimas intracelulares de Lactococcus sp. foram detectadas em todos os tratamentos, mas em intensidades distintas, variando conforme a linhagem empregada ou o tipo de fabricação envolvida.

Foi no extrato aquoso de Trad AM2 que detectou-se a maior intensidade de enzimas, já a partir de D+1, mantendo-se constante em todo o período de armazenamento (Figura 20a). No tratamento Trad AM2-C, também foi detectado a presença de proteínas intracelulares em $\mathrm{D}+1$, mas com intensidades inferiores, observando-se a disparição quase total de uma banda de peso molecular entre 67 e 43 kDa (Figura 20b) ao final do período estudado. Já nos queijos-UF, detectou-se quantidades bastante inferiores de enzimas intracelulares nos extratos aquosos em ambos os tratamentos, UF AM2 e UF AM2-C, mostrados na Figura 20cd. Através dessa análise, observaram-se diferenças de comportamento das linhagens quanto a quantidade de enzimas intracelulares liberadas, que variaram conforme a tecnologia de fabricação empregada. 

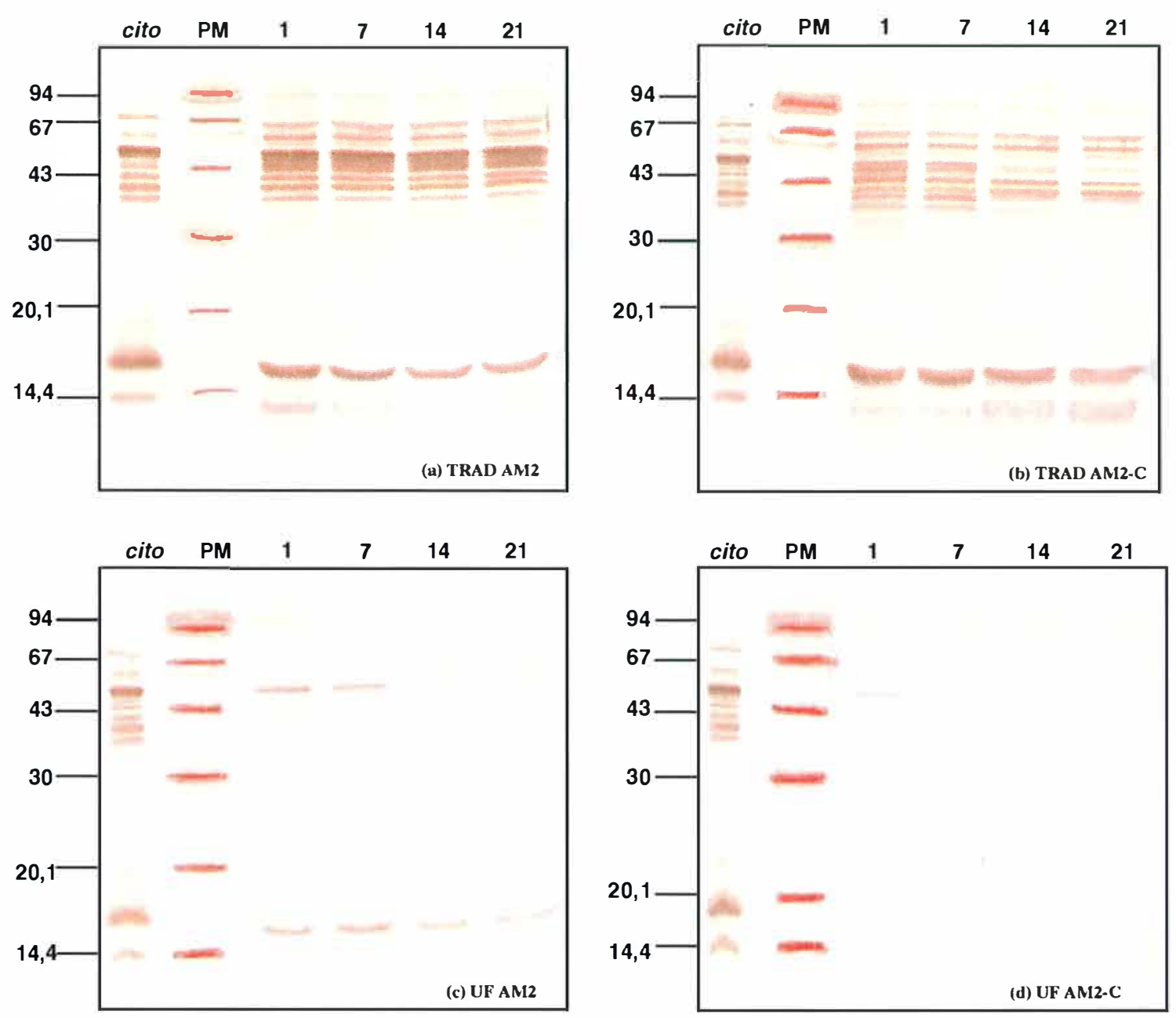

Figura 20 - Immunoblotting com citosol de soro anti-lactococos (anti-LC) mostrando a intensidade da autólise das linhagens L. lactis subsp. cremoris AM2 ou AM2-C no queijo Minas Frescal fabricado através de tecnologias tradicional ou UF em amostras tomadas durante o período de armazenamento (1, 7, 14 e 21 dias). (a) Trad AM2; (b) Trad AM2-C; (c) UF AM2; (d) UF AM2-C. Na primeira coluna de cada Immunoblotting, encontra-se o citoplasma bruto de lactococos (cito), utilizado como referência. A massa molecular padrão de proteínas está indicada ao lado esquerdo de cada blotting. 


\subsubsection{Visualização de bactérias nos queijos tradicionais e ultrafiltrados através de microscopia eletrônica por varredura}

Através da análise em microscopia eletrônica por varredura, pôde-se visualizar a presença de colônias de lactococos nas amostras de queijos Minas Frescal tomadas após 48 horas da fabricação. Observou-se, também, diferenças quanto à microestrutura interna dos queijos, decorrentes do tipo de processo de fabricação envolvido (tradicional ou UF). As fotos de microscopia eletrônica por varredura estão mostradas na Figura 21.

No queijo Minas Frescal tradicional, fabricado com a linhagem autolítica (Trad AM2), não foi possível visualizar nenhuma colônia (Figura 21 a). De acordo com a estimativa de células viáveis por plaqueamento, elas encontravam-se a um nível muito baixo $\left(10^{5} \mathrm{ufc} / \mathrm{g}\right)$, o que limita a sua visualização pela técnica de microscopia eletrônica por varredura. Porém, essa mesma linhagem pôde ser visualizada no queijo fabricado por UF (UF AM2), encontrando-se em bom estado fisiológico, formando colônias (Figura 2 lc). Nos queijos fabricados com a linhagem não-autolítica (Trad AM2-C e UF AM2-C) as células também foram perfeitamente visualizadas em colônias (Figura 21 bd).

A microscopia eletrônica por varredura revelou que a microestrutura interna nos queijos Minas Frescal fabricados pelo processo tradicional é bastante heterogênea (Figura 21e). Ao contrário, nos queijos fabricados por UF, observou-se uma microestrutura homogênea (Figura 21f), mostrando claramente o local de inserção dos glóbulos de gordura. 

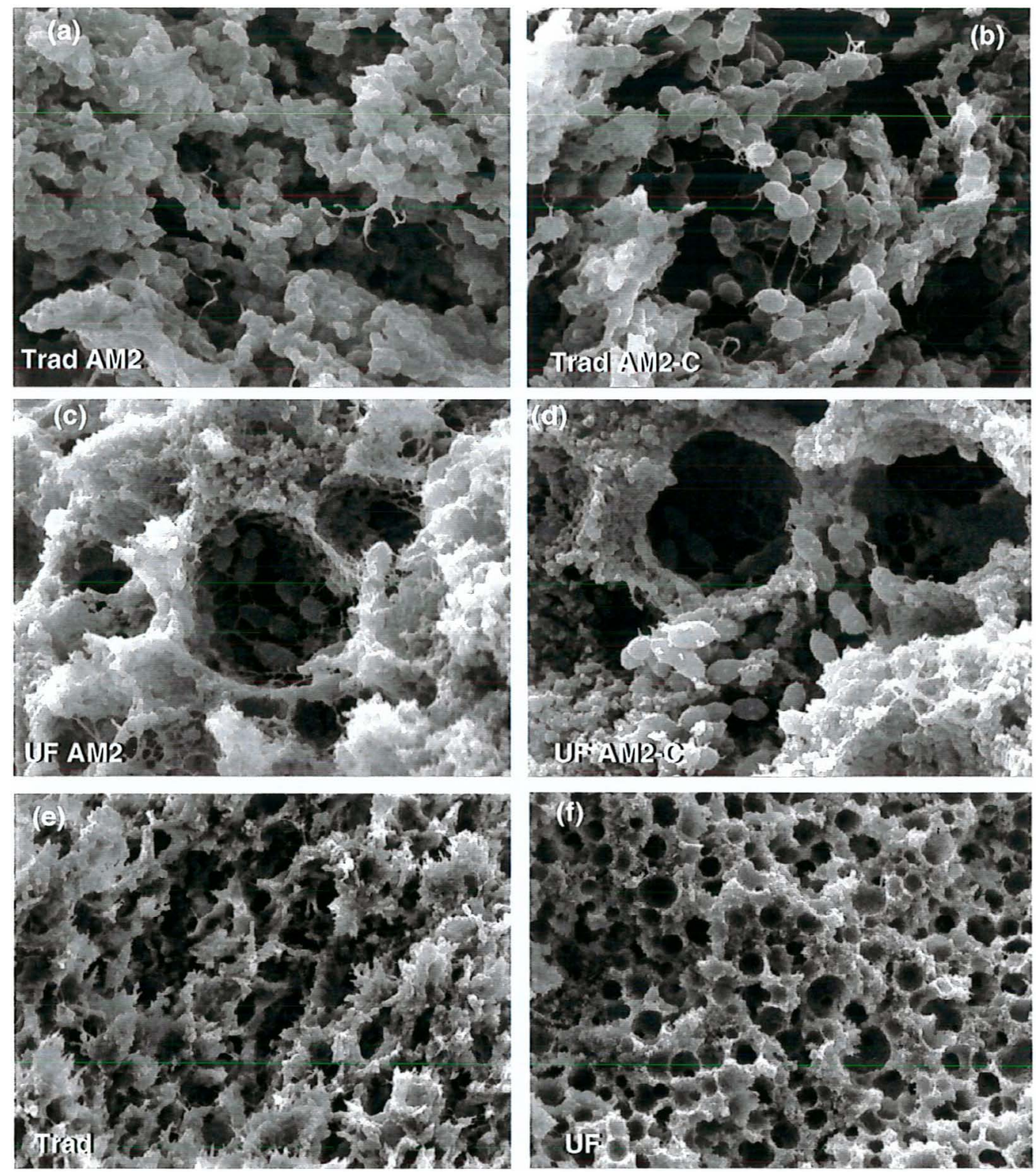

Figura 21 - Fotos de microscopia eletrônica por varredura do queijo Minas Frescal fabricado com L. lactis subsp. cremoris AM2 e AM2-C através das tecnologias tradicional e por UF a 48 horas após a fabricação. (a) porção interna do queijo Trad AM2; (b) colônias de lactococos queijo Trad AM2-C; (c) colônias de lactococos no queijo UF AM2; (d) colônias de lactococos no queijo UF AM2-C; (e) microestrutura interna geral do queijo tradicional; (f) microestrutura interna geral do queijo fabricado através de UF. Fotos a, b, c, d: aumento de 10.000 vezes; e, f: aumento de 2.500 vezes. 


\subsubsection{Evolução da proteólise durante o armazenamento}

A proteólise dos queijos foi analisada primeiramente mensurando-se a evolução da degradação das diferentes frações nitrogenadas (NCN e NPN), expressas em porcentagem do nitrogênio total (NT). Os índices de extensão (NCN/NT \%) e de profundidade da proteólise (NPN/NT \%) estão mostrados na Figura 22 e na Figura 23, respectivamente. Em todos os tratamentos, os resultados mostram um aumento gradual dessas relações, com maior ou menor intensidade, em função do tratamento em questão.

\subsubsection{1 Índice de extensão da proteólise NCN/NT (\%)}

Através da Figura 22 observou-se que os queijos-UF apresentaram índices de extensão de proteólise (NCN/NT) bem mais elevados em $\mathrm{D}+1$ do que os queijos tradicionais. Esse fato se deve à maior retenção das proteínas do soro pelo próprio processo de UF. Portanto, a avaliação desses valores não será feita em valores absolutos, mas considerando-se a variação relativa ocorrida durante o armazenamento.

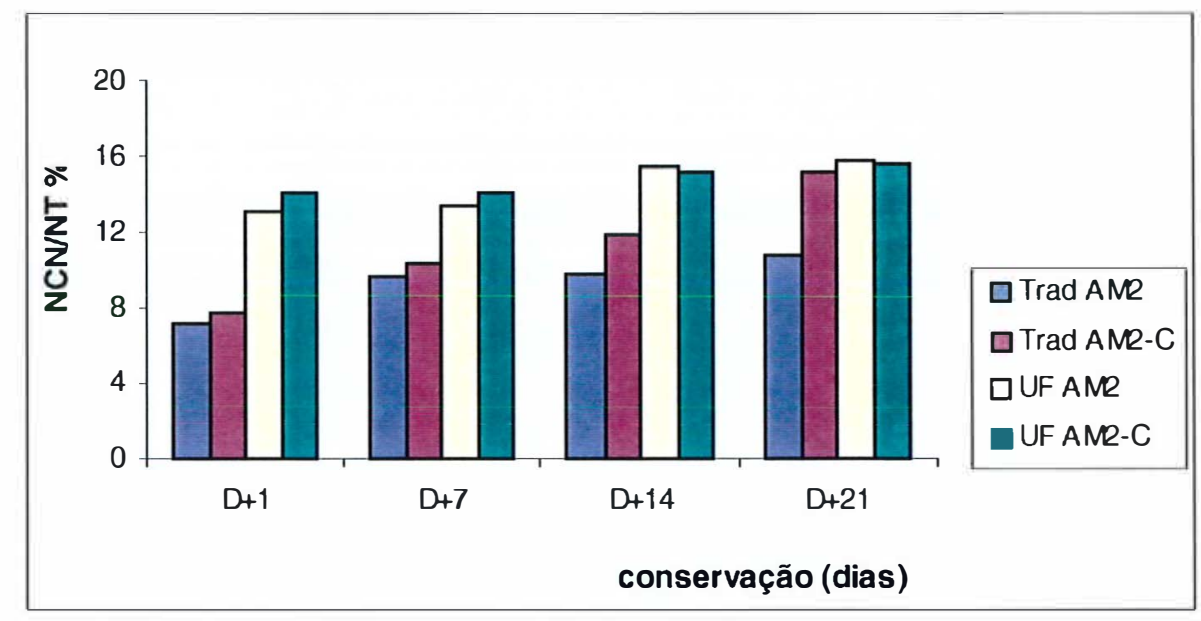

Figura 22- Evolução dos teores de NCN expressos em \% do NT (índice de extensão da proteólise) durante o armazenamento a $5^{\circ} \mathrm{C}$ de queijos Minas Frescal obtidos por tecnologias tradicional ou UF, com 2 linhagens de L. lactis

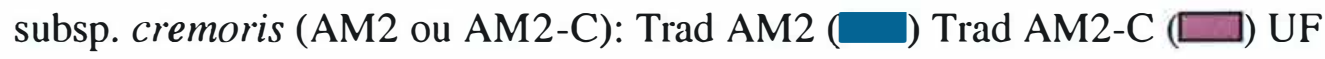

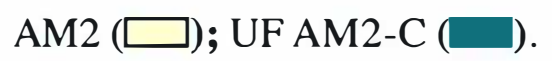


Nos queijos tradicionais, no tratamento Trad AM2, a relação NCN/NT (\%) variou de 7,14\% em D+1 para 10,78\% em D+21 e no tratamento Trad AM2-C, verificou-se uma evolução mais acentuada, de 7,68 \% para 15,52 \% em D+21. Para os queijos-UF, no tratamento UF AM2 essa relação variou de $13,16 \% \mathrm{em} \mathrm{D+1}$ atingindo o valor de $15,54 \%$ em D+21 e no tratamento UF AM2-C 14,11\% para 15,54\%. Observou-se, portanto, que as variações da relação NCN/NT foram menores nos queijosUF, evidenciando-se, assim, que esses queijos são mais resistentes à proteólise que os queijos tradicionais.

\subsubsection{2 Índice de profundidade da proteólise NPN/NT (\%)}

A Figura 23 mostra os histogramas referentes às relações entre o NPN e o NT (\%) dos queijos Minas Frescal tradicional e UF durante o armazenamento refrigerado. Os resultados indicaram a ocorrência de um aumento gradual dos índices de profundidade da proteólise no decorrer do período, em todos os ensaios.

Constataram-se valores de NPN/NT (\%) um pouco mais elevados em $\mathrm{D}+1$ nos queijos-UF do que nos queijos tradicionais. Isso se deve ao fato desse processo reter as caseínas-macro-peptídeo (CMP), que são determinadas na forma de NPN. Nos queijos obtidos por processos tradicionais, as CMP são perdidas no soro. No tratamento Trad AM2 o índice de profundidade da proteólise não evoluiu muito, passando de 2,86 $\%$ para apenas $4,27 \%$ em D+21. No entanto, observou-se um aumento bastante elevado no tratamento em que empregou-se a linhagem não-autolítica (Trad AM2-C), onde o índice de profundidade da proteólise em D+1 foi de 2,77 \% e atingiu um valor de 7,77 \% em $\mathrm{D}+21$. Por outro lado, verificou-se que não houve diferença tão acentuada desse índice nos queijos-UF, evidenciando que as linhagens comportaram-se distintamente nos dois tipos de processos de fabricações.

No tratamento UF AM2, em D+l o NPN/NT foi de 3,24\% e chegou a $3,30 \%$ em $\mathrm{D}+21$. No caso do tratamento UF AM2-C, o índice de profundidade da proteólise evoluiu um pouco mais, de 3,39\% (D+1) para 5,56\% em D+21. 


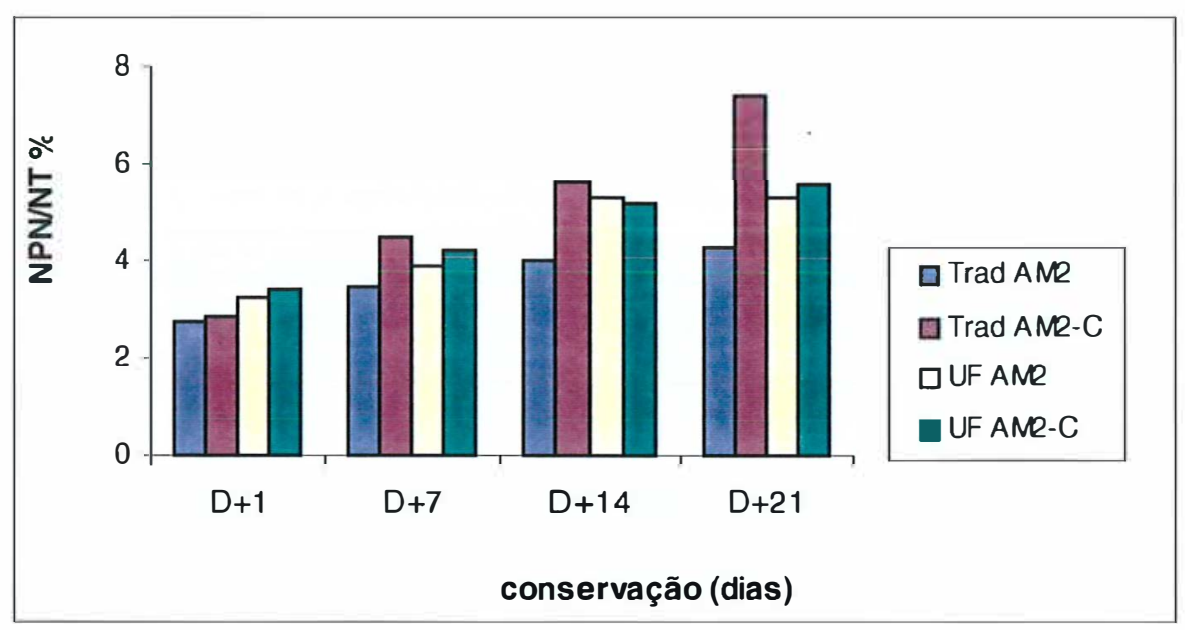

Figura 23- Evolução dos teores de NPN expressos em \% do NT (índice de profundidade da proteólise) em queijos Minas Frescal fabricados por tecnologias tradicional ou UF, com 2 linhagens de L. lactis subsp. cremoris (AM2 ou

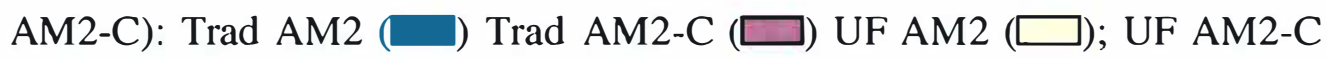
(ए), durante o armazenamento a $5^{\circ} \mathrm{C}$.

Os índices da extensão e da profundidade da proteólise são considerados índices brutos, não refletindo a totalidade das transformações que as proteínas sofrem durante o processo de maturação ou armazenamento. Por isso, também avaliamos a proteólise com base em análises eletroforéticas e em HPLC, cujos resultados serão apresentados a seguir.

\subsubsection{SDS-PAGE}

Os perfis eletroforéticos das proteínas contidas nos extratos aquosos dos queijos Minas Frescal (tradicional e Ultrafiltração), analisados durante o armazenamento a $5^{\circ} \mathrm{C}$, são mostrados na Figura 24.

As análises de proteínas através de eletroforese (SDS-PAGE) confirmaram os resultados obtidos através das análises das diferentes formas de nitrogênio (NCN e NPN). Nos queijos Trad AM2, verificou-se através do perfil das proteínas, que a proteólise ocorreu de forma pouco intensa, pois quase não foram observados fragmentos menores que 14,4 kDa (Figura 24a), mostrando-se estáveis ao 
longo do armazenamento. Ao contrário, o gel referente ao tratamento Trad AM2-C, mostrou um acúmulo de pequenos fragmentos menores que 14,4 kDa, visualizados com bastante intensidade a partir de D+14 (Figura 24b), refletindo uma proteólise bastante intensa. Já nos queijos-UF, verificou-se, através da análise em SDS-PAGE, que os mesmos mantiveram-se bastante estáveis durante o armazenamento (Figura 24cd). Ressalta-se ainda, que entre os dois tratamentos (UF AM2 e UF AM2-C) as diferenças nos perfis eletroforéticos são menos intensas do que nos queijos tradicionais (Trad AM2 e Trad AM2-C).

\subsubsection{Análises de peptídeos em HPLC}

As análises de peptídeos através de HPLC foram realizadas somente nos queijos tradicionais em $\mathrm{D}+1$ e em $\mathrm{D}+14$, em vista das diferenças marcantes de proteólise constatadas entre eles durante o período de armazenamento. Os perfis cromatográficos encontram-se na Figura 25.

Os perfis obtidos em D+1, referentes aos queijos Minas Frescal tradicionais fabricados com as linhagens AM2 e sua variante curada AM2-C, mostraram-se bastante diferentes. A deteç̧ão de picos peptídicos em $\mathrm{D}+1$ foi muito maior em intensidade e número no caso do queijo Trad AM2-C (Figura 25). Em D+14, essa diferença entre os dois tratamentos atenuou-se, pois ocorreu uma certa proteólise pela linhagem AM2.

A análise de espectrometria de massa dos queijos Trad AM2 e Trad AM2-C identificou 18 massas diferentes no queijo Trad AM2 em D+1, sendo $67 \%$ delas comuns ao tratamento Trad AM2-C. Porém, neste último, foi identificado um número maior de massas (total de 38). Em D+14, o número total de massas identificadas no Trad AM2 foi de 86, contra 120 no Trad AM2-C, sendo 44 massas similares. 

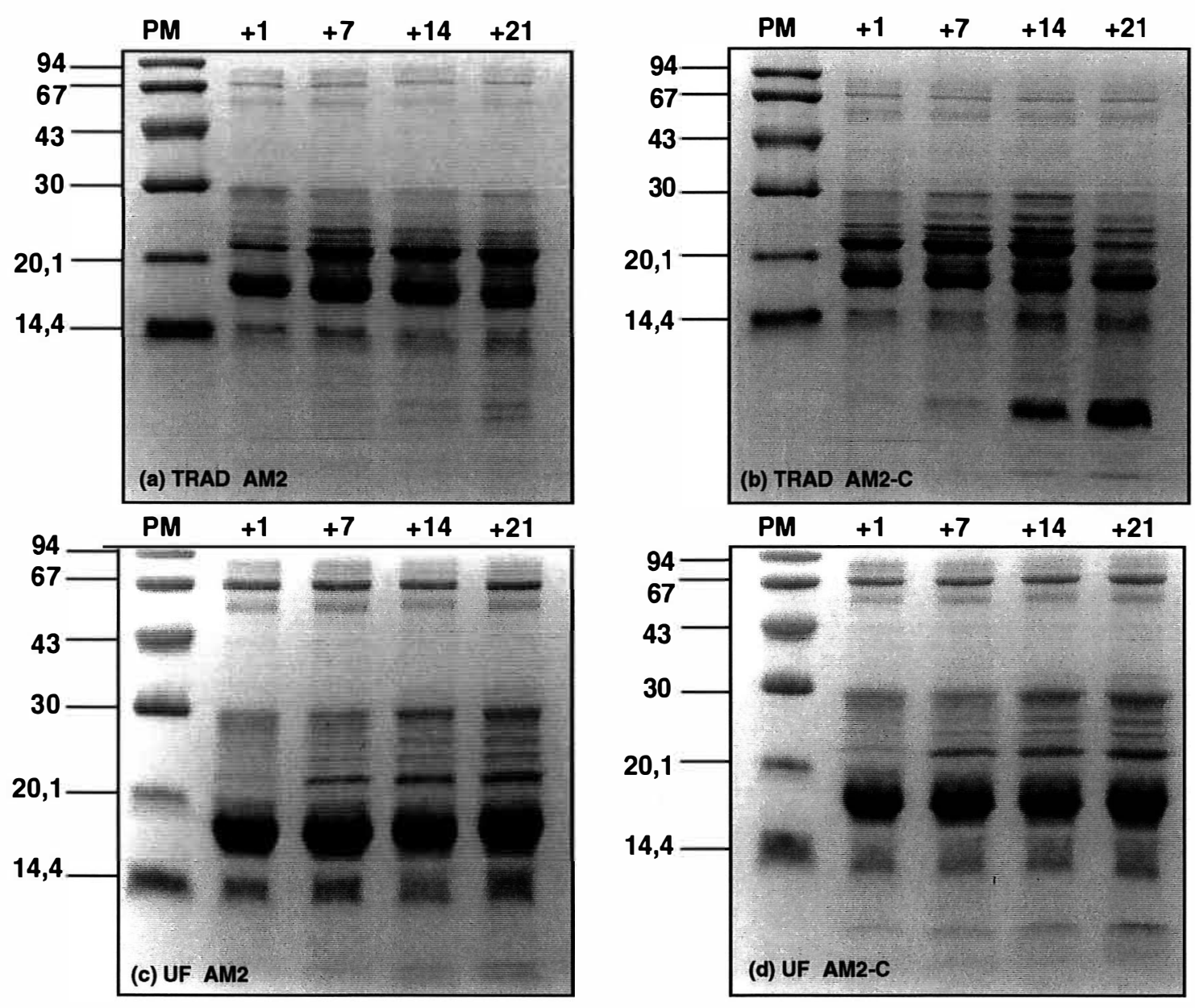

Figura 24 - SDS-PAGE dos extratos aquosos de amostras do queijo Minas Frescal tomadas durante o armazenamento a $5^{\circ} \mathrm{C}$, mostrando diferenças no perfil de proteínas, em função do tipo de tecnologia empregada (tradicional ou Ultrafiltração) e da linhagem de L. cremoris utilizada (AM2 ou AM2-C). (a) Trad AM2; (b) Trad AM2-C; (c) UF AM2; (d) UF AM2-C. A massa molecular padrão está indicada ao lado esquerdo de cada figura. (PM = peso molecular). $+1,+7+14+21$ : são os dias após a fabricação dos queijos, em que foram tomadas as amostras. 

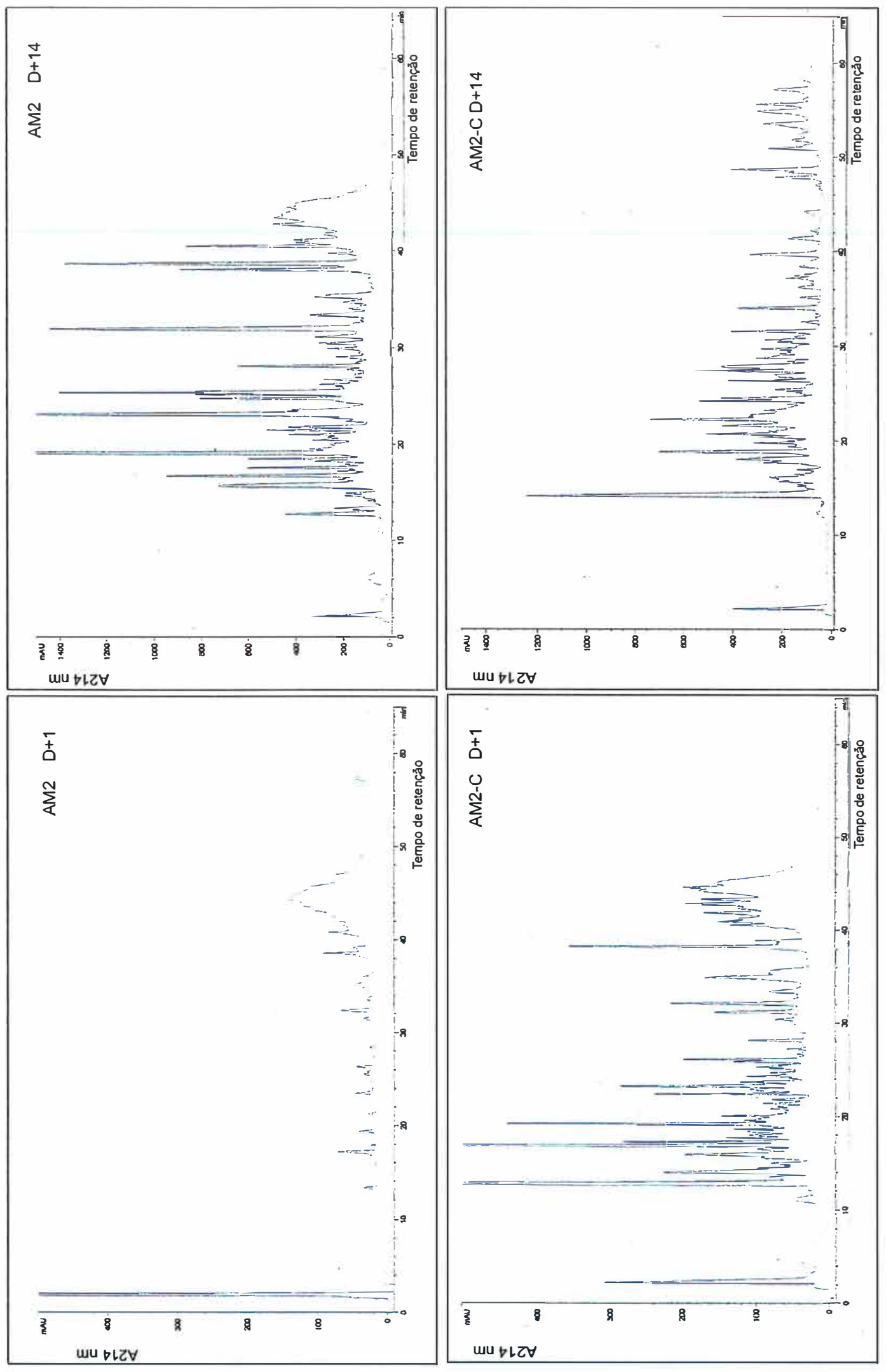

吉

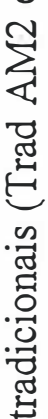

तु

点

运

$: \stackrel{0}{\stackrel{\circ}{\overparen{J}}}$

ช

今 虽

穿

क

$\sim$

㐘 


\subsection{Discussão}

A Microfiltração do leite para a fabricação do queijo Minas Frescal (tradicional ou UF) permitiu a retirada da quase totalidade dos microrganismos inicialmente presentes $(99,98 \%)$. Dessa forma, foi possível analisar o comportamento de cada linhagem de Lactococcus lactis subsp. cremoris (AM2 ou AM2-C) adicionada e atribuir a cada uma todos os possíveis efeitos gerados nos queijos durante o seu armazenamento, visto que não havia a presença de artefatos (bactérias mortas, células somáticas, esporos) ou interferências de outras floras bacterianas. As taxas de inoculação de ambas as culturas lácticas no leite de fabricação dos queijos tradicionais, ocorreram de forma adequada, ao redor de $8 \times 10^{6} \mathrm{ufc} / \mathrm{ml}$, confirmando, assim, que ambos os lotes de leite possíam quantidades similares de cultura láctica. Já os dois lotes de retentados de UF foram inoculados com quantidades similares de células, mas propositadamente superiores ( $3 \times 10^{7} \mathrm{ufc} / \mathrm{ml}$ de retentado), devido ao seu elevado poder tamponante, que dificulta o abaixamento do $\mathrm{pH}$ pelo ácido láctico produzido pela flora fermentativa.

Mesmo possuindo características autolíticas distintas, as duas linhagens de L. cremoris (AM2 ou AM2-C) geraram cinéticas de acidificação idênticas durante toda a fabricação dos queijos tradicionais. Isso mostra que as duas linhagens tiveram o mesmo comportamento durante toda a fabricação quanto à produção de ácido láctico, até a última viragem dos queijos, avaliada através dos valores de $\mathrm{pH}(6,22$ e 6,26, respectivamente Trad AM2 e Trad AM2-C). Além disso, a contagem de células bacterianas resultantes no soro de fabricação de tais queijos também foram similares ( $10^{5}$ ) e ocorreram numa taxa considerada normal para tal o processo de fabricação, indicando a não ocorrência de autólise diferencial durante esse período. Para a obtenção dos queijos-UF, a acidificação do retentado pelas duas linhagens, também ocorreu de forma similar, mostrando que nesse caso, assim como no anteriormente citado, a acidificação deu-se de forma análoga para a obtenção desse tipo de queijo. 
Pelas análises de composição centesimal, pudemos averiguar que os valores do extrato seco total (EST) dos queijos dos 4 tratamentos eram similares. Além disso, apresentavam a mesma umidade no extrato seco desengordurado (UESD) em D+1. Segundo Furtado (1990), do ponto de vista técnico, o UESD apresenta a melhor correlação com a consistência do queijo e o fenômeno da proteólise, que é um dos objetivos deste estudo. Assim, esses tratamentos puderam ser comparados entre si.

Os valores distintos de $\mathrm{pH}$ encontrados nos queijos tradicionais em D+1 $(6,2$ e 5,4$)$, provavelmente estão associados às linhagens. Observou-se uma queda elevada do número de células viáveis no tratamento Trad AM2 já em D+1. Portanto, mesmo existindo lactose remanescente, a quantidade de células existente não foi suficiente para acidificar o meio, e aumentar sua concentração hidrogeniônica, como ocorreu em Trad AM2-C. O valor do $\mathrm{pH}$ ao redor de 6,0 em Trad AM2 permaneceu constante até D+21. Em contrapartida, o valor do pH de Trad AM2-C diminuiu, tendo um decréscimo maior em $\mathrm{D}+21(\mathrm{pH}=4,9)$, com a contínua produção de ácido láctico pelas bactérias.

A queda acentuada do número de células viáveis observada no tratamento Trad AM2 em D+1, foi causada, provavelmente, por um choque térmico realizado de forma não proposital, ou seja, devido ao efeito da mudança de temperatura de fabricação $\left(30^{\circ} \mathrm{C}\right)$ para a de armazenamento $\left(5^{\circ} \mathrm{C}\right)$ num espaço de tempo reduzido, induzindo a lise da linhagem autolítica AM2 até D+7. De maneira surpreendente, observou-se um aumento da população em $\mathrm{D}+14$ e $\mathrm{D}+21$.

Através da técnica de Immunoblotting, pôde-se confirmar que a queda inicial de viabilidade observada em $\mathrm{D}+1$ e $\mathrm{D}+7$ no tratamento Trad AM2 foi conseqüência da autólise, visto que enzimas intracelulares de Lactococcus sp. foram detectadas em elevada quantidade na matriz do queijo e não foi possível visualizar colônias de bactérias em Trad AM2 através de microscopia eletrônica por varredura. Demonstrou-se, assim, a ocorrência de lise desse gênero de bactéria no queijo Minas Frescal, obtido pelo processo tradicional de fabricação.

Já no tratamento em que se adicionou a linhagem não-autolítica (Trad AM2-C), não houve queda significativa do número de células viáveis durante o 
armazenamento. Visualizaram-se bactérias lácticas em adequado estado fisiológico na matriz do queijo, através da microscopia eletrônica. Detectaram-se enzimas intracelulares de Lactococcus sp. através de Immunoblotting, porém em níveis menos expressivos do que no tratamento Trad AM2. Portanto, essa linhagem também se lisou nesse queijo, mas em menor taxa.

Ambos os quadros eram esperados, devido aos perfis já conhecidos dessas linhagens com relação à lise (Lepeuple et al., 1998). Porém, o comportamento de tais linhagens em um queijo do tipo fresco, de massa mole como o Minas Frescal, nunca fora anteriormente relatado e tampouco o impacto da lise na proteólise durante o período de armazenamento a frio. A linhagem autolítica $L$. cremoris AM2 tem como principal característica promover elevada taxa de autólise em queijo precocemente (ChapotChartier et al., 1994); possui dois mecanismos de lise acumulados, um devido ao profago e outro devido às enzimas localizadas na parede celular, as autolisinas. No caso da linhagem L. cremoris AM2-C, por ter sido curada, um desses mecanismos promotores da lise foi perdido, ou seja, o profago e, portanto, as endolisinas; no entanto, ainda possui as autolisinas. Consequentemente, são somente essas últimas as responsáveis pela lise observada nesse queijo (Trad AM2-C); sendo assim, a taxa de lise foi menor e as enzimas intracelulares de L. cremoris AM2-C foram detectadas com menor intensidade.

$\mathrm{O}$ índice de profundidade da proteólise de Trad AM2-C, mostrou-se $73,77 \%$ superior ao do tratamento Trad AM2 em D+21, o qual está estritamente relacionado com a atividade da linhagem bacteriana. Essa diferença teve reflexo direto na reologia dos queijos tradicionais. Os queijos daquele tratamento (Trad AM2-C) perderam forma física rapidamente, enquanto que os queijos do tratamento Trad AM2 conservaram suas características por mais tempo. Em D+14, encontravam-se já bastante descaracterizados quanto à textura (Fotos: Anexo D5 e D6). Essa diferença encontrada com relação à proteólise secundária nos queijos tradicionais fabricados com as duas linhagens de L. cremoris (AM2 e AM2-C) pareceu incoerente, pois essas linhagens possuem o mesmo potencial enzimático, diferindo apenas em suas capacidades quanto à lise (Lepeuple et al., 1998). Isso pode estar relacionado a uma resposta das proteases 
ligadas à parede celular que, para compensar a perda do profago responsável pela lise, tornaram-se altamente ativas no queijo Trad AM2-C. Esse fato foi confirmado pelas análises em HPLC, demonstrando que a linhagem AM2-C provocou maior proteólise, devido ao maior número e intensidade de picos peptídicos observados nesse tratamento em realação àquele envolvendo a linhagem AM2 .

As enzimas intracelulares de AM2 liberadas após a lise celular e aquelas associadas à parede celular, parecem não ter tido atuação no queijo Trad AM2. Possivelmente, as peptidases liberadas não conseguiram atuar, pois as caseínas ainda não se encontravam suficientemente degradadas para serem atacadas por essas enzimas (sítios não-ativos); as proteases associadas à parede celular estariam, provavelmente inativas após o rompimento celular ou não se difusam pela matriz do queijo.

Curiosamente, as linhagens de L. cremoris (AM2 ou AM2-C) não tiveram o mesmo comportamento quanto à lise nos queijos-UF, como aquele observado nos queijos tradicionais. Nos dois tratamentos (UF AM2 e UF AM2-C) constatou-se um impacto semelhante e limitado na proteólise durante o armazenamento, em razão da baixa taxa de autólise observada em ambos e da resistência das proteínas do soro à atividade de peptidases e enzimas ligadas à parede celular em queijos-UF (Mistry \& Maubois, 1993). A lise foi detectada no tratamento UF AM2 em intensidade muito inferior àquela verificada pela mesma linhagem no queijo tradicional (Trad AM2) e o mesmo foi observado no tratamento UF AM2-C. Portanto, a lise de Lactococcus sp., em queijos-UF, é ínfima, como observado por Saboya et al. (2001), mesmo em se tratando de uma linhagem com característica autolítica marcante, como é o caso de L. cremoris AM2.

Para tentar explicar esse fato, levantamos duas hipóteses. A primeira, de que a protease sendo associada à parede celular possui uma função na regulação da atividade da autolisina $\mathrm{N}$-acetil muramidase (AcmA), a qual é a mais importante encontrada em L. lactis. Essa protease parece transformar a forma inativa (46kDa) da autolisina na forma ativa lítica (41 kDa) (Buist et al., 1998; Govindasamy-Lucey et al., 2000). Pode-se imaginar que se a protease fosse inibida nos queijos-UF (Bech, 1993; Jameson \& Lelievre, 1996), essa ativação não mais ocorreria. Assim, uma fraca 
atividade de AcmA, resultaria em uma lise pouco intensa. Outra hipótese, seria de que a composição dos queijos-UF (sais minerais e proteínas solúveis concentrados) mudaria a composição da superfície celular e, então, as autolisinas ou lisinas do fago seriam incapazes de degradar seu substrato (a parede celular).

A visualização das microestruturas dos queijos Minas Frescal através de microscopia eletrônica por varredura, permitiu avaliar as diferenças reológicas existentes, em função do tipo de tecnologia de fabricação envolvido. Observou-se que, com tecnologia tradicional, os queijos possuíam microestrutura heterogênea, conseqüência de coagulação irregular, induzindo o soro a migrar em interfaces variadas. Por outro lado, no processo de UF, onde o queijo é obtido a partir de uma solução concentrada (o retentado), a formação da rede está associada à concentração de proteínas e, por não ter havido dessora, a coagulação ocorreu de forma estática, resultando em microestruturas homogêneas (Maubois, comunicação pessoal).

Por fim, observou-se que os queijos Minas Frescal fabricados com leite microfiltrado por ambas tecnologias, apresentaram sabor agradável por maior período de tempo, do que aqueles comumente encontrados no mercado, fabricados com leite pasteurizado. Esse fato está relacionado à ausência de células somáticas, bactérias mortas e esporos no leite obtido pelo processo de MF. A presença de células somáticas no leite em níveis superiores a $4 \times 10^{5} \mathrm{ccs} / \mathrm{ml}$, podem induzir defeitos detectáveis nos produtos lácteos, tais como lipólise e proteólise não controladas e perda de rendimento de fabricação de queijos (Andrews, 1983). Essas células são todas retidas pela membrana de MF e, consequentemente, o leite microfiltrado não será degradado pelas enzimas termodúricas de leucócitos (Law \& Goodenough, 1995). Observa-se um melhoramento no rendimento, nas características sensoriais e na qualidade higiênica de produtos de longa duração, como o leite fluido e queijos (Maubois, 1997a). 


\subsection{Conclusões}

Pelos resultados obtidos, pôde-se concluir que o comportamento quanto à lise das linhagens AM2 e AM2-C de L. lactis subsp. cremoris e seu impacto na proteólise do queijo Minas Frescal diferem marcadamente em função da tecnologia de fabricação envolvida. Em tecnologia tradicional, a linhagem AM2 mostrou-se altamente autolítica, como já descrito em outros queijos tradicionais maturados, porém não teve impacto expressivo na proteólise. Ao contrário, a linhagem AM2-C, apresentou pequena taxa de autólise, porém teve um impacto elevado na proteólise, que foi atribuído a uma atividade da protease ligada à parede celular. Nos queijos obtidos por Ultrafiltração, observou-se que as duas linhagens comportaram-se de forma parecida, com implicações semelhantes na proteólise. Verificou-se que, mesmo no caso da linhagem com perfil autolítico (AM2), a lise de Lactococcus sp. em queijos-UF foi muito fraca e pode ter sido inibida por componentes existentes no retentado de UF. Tais queijos evoluíram muito pouco, devido ao restrito impacto dessas linhagens na proteólise. Confirmou-se, assim, uma fraca taxa de lise de Lactococcus sp. em queijos-UF.

Essas afirmações só puderam ser feitas por ter-se utilizado como matériaprima o leite microfiltrado para a fabricação dos queijos. A retirada de $99,98 \%$ das bactérias e células somáticas totais existentes no leite cru, através do processo de Microfiltração, permitiram o total controle do meio, sem a presença de artefatos que pudessem interferir na atividade das linhagens testadas. Além disso, o leite microfiltrado mostrou-se adequado para fabricar queijos do tipo fresco, pois com a retirada significativa de contaminantes, favorece a flora principal adicionada, podendo-se prolongar a vida útil desse produto e promover um melhor sabor. 


\section{CONCLUSÕES GERAIS}

Através dos resultados obtidos com a utilização de marcadores específicos de enzimas intracelulares em Immunoblotting, pôde-se confirmar e demonstrar a ausência de lise de Lactococcus sp. em queijos fabricados pelo processo de Ultrafiltração, independentemente da atividade lítica intrínseca da linhagem. Esses resultados foram observados em duas variedades muito diferentes de queijos, Minas Frescal, do tipo massa mole e Saint Paulin, do tipo massa semi-dura, assim como em queijos-UF comerciais obtidos com diferentes tipos de leite (vaca, cabra e ovelha). A causa dessa ausência de lise pode estar relacionada ao poder tamponante dos queijos fabricados através dessa tecnologia, onde o lactato de cálcio estando concentrado, pode ter um efeito inibidor sobre os mecanismos da lise de lactococos.

A ausência de lise de Lactococcus sp. em queijos-UF tem efeitos diretos na proteólise, com reflexos distintos em se tratando de um queijo maturado ou do tipo fresco. No queijo UF-Saint Paulin a ausência de lise resultou numa fraca proteólise secundária, com observação de pouca formação de peptídeos, aminoácidos e compostos aromáticos, principalmente nos queijos testemunhas. Esse fato implica na necessidade de prolongar o período de maturação, com consequiências econômicas. Em contrapartida, no queijo UF-Minas Frescal, a ausência de lise traduziu-se em estabilização do produto, devido à baixa evolução da proteólise. Esse quadro foi reforçado pelo emprego concomitante de leite desbacterizado pelo processo de Microfiltração, que assegura um total controle da flora microbiana, favorecendo a cultura láctica adicionada. Assim, obtém-se uma estabilização bioquímica e microbiológica que resulta num aumento da vida comercial do produto. 
A adição de extratos intracelulares de Lactococcus sp. ou Propionibacterim freudenreichii, obtidos através de um homogeneizador-piloto à alta pressão, foi uma forma adequada encontrada para interferir nos fenômenos da proteólise do queijo UF-Saint Paulin e compensar a ausência de lise da cultura láctica, observada em queijos desse tipo. O homogeneizador-piloto à alta pressão mostrou ser um meio fácil, eficaz e rápido na obtenção dos extratos intracelulares, permitindo a conservação da atividade das enzimas presentes. A adição de extratos intracelulares de Lactococcus sp., promoveu um maior impacto sobre conteúdo em aminoácidos livres, mas não afetou a taxa de NPN/NT e nem produziu efeitos sobre a formação de compostos voláteis nos queijos UF-Saint Paulin durante a maturação. Já a adição de extratos intracelulares de $P$. freudenreichii, resultou em aumento no índice de NPN/NT, associado à elevação da temperatura de maturação dos queijos UF-Saint Paulin. Houve mudanças qualitativas no perfil de aminoácidos livres e novos compostos aromáticos foram formados, particularmente álcool e cetonas, mas somente quando os extratos continham células inteiras.

Demonstrou-se neste trabalho, ser fundamental, para a qualidade final de queijos frescos ou maturados, a caracterização de linhagens de bactérias lácticas quanto às suas propriedades autolíticas. Concluiu-se, ainda, que a aplicação de tecnologias modernas, como a Ultrafiltração e a Microfiltração do leite permitem a obtenção de produtos padronizados, garantem a segurança higiênica, com conseqüente aumento da durabilidade comercial de queijos e possibilitam a valorização do leite e o desenvolvimento de novos produtos lácticos. 
ANEXOS 
ANEXO A

Ilustrações referentes à Microfiltração do Leite 


\section{MiCROFILTRAÇÃo DO LEITE}

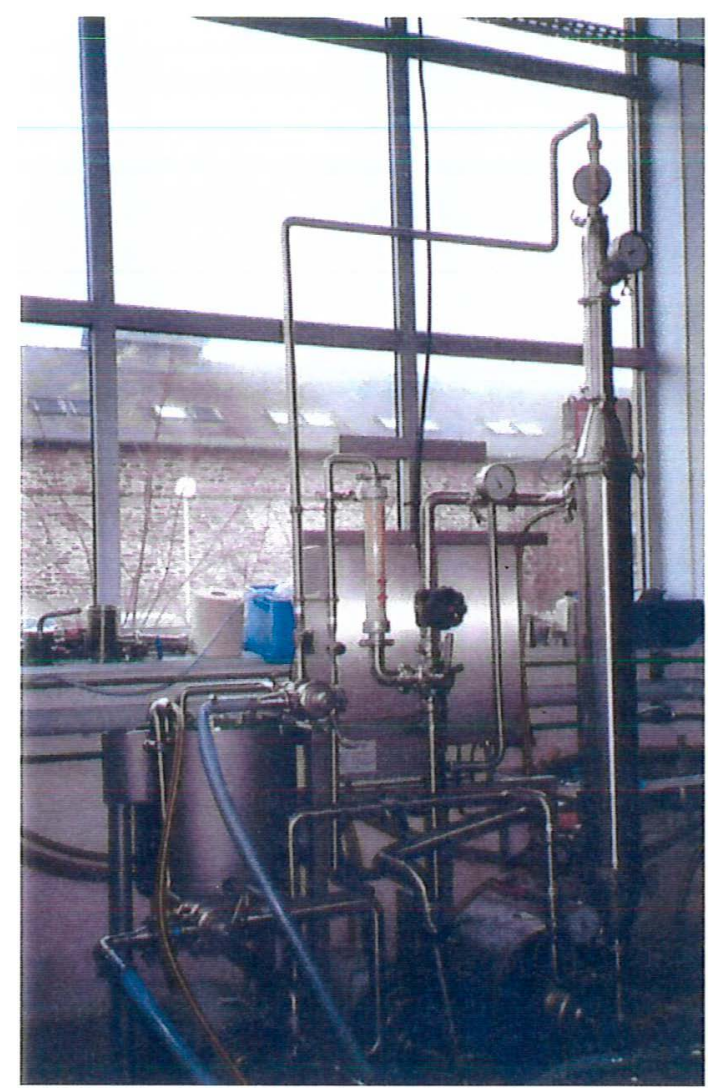

Foto Anexo A1 - Unidade Piloto GP 7 (TetraLaval, Aahus, Dinamarca) equipado com 1,68 $\mathrm{m}^{2}$ de membranas Membralox ${ }^{\circledR}$ GP (Société des Céramiques Techniques, Bazet, França) com tamanho médio de poro de $1,4 \mu \mathrm{m}$. Pertencente ao Laboratoire de Recherche de Technologie Laitière - Centro INRA de Rennes, França - utilizado para a obtenção do leite microfiltrado.

Foto Anexo A2 - Leite microfiltrado comercializado na França com o nome comercial de Marguerite $^{\circledR}, \quad$ com durabilidade de quinze dias sob refrigeração a $6^{\circ} \mathrm{C}$.

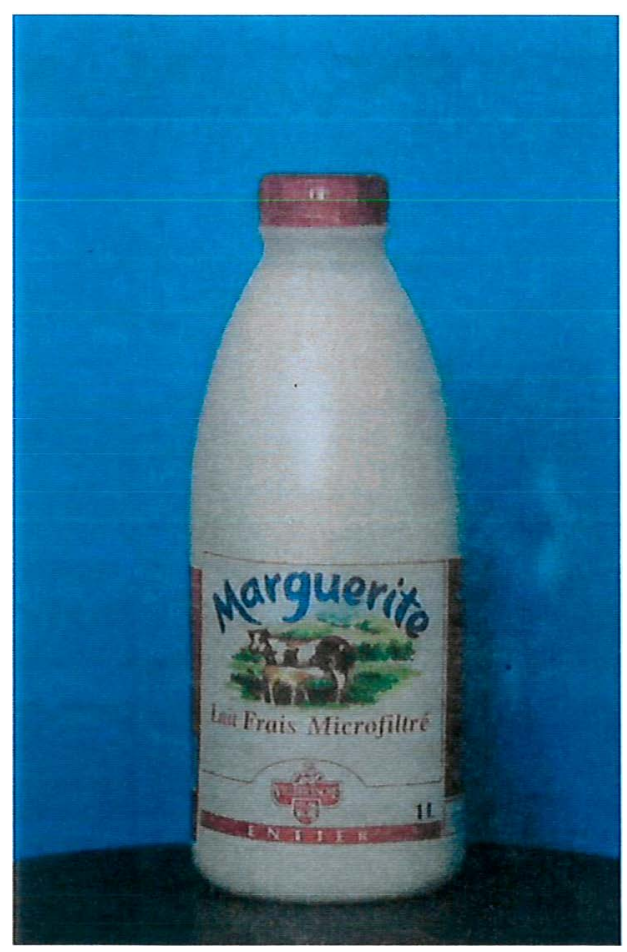




\section{ANEXO B}

Metodologia utilizada para avaliar a lise de Lactococcus $s p$.

(Immunoblotting) 


\section{AVALIAÇÃo DA LISE DE BACTÉRIAS EM QUEIJOS ATRAVÉS DE IMMUNOBLOTTING}

Para avaliar a autólise de Lactococcus sp. nos queijos estudados nesse trabalho, o Saint Paulin (Ultrafiltrado), o Minas Frescal (tradicional e Ultrafiltrado) e quatro queijos Ultrafiltrados do comércio francês, utilizou-se a técnica de Immunoblotting, desenvolvida por Valence (1999). Através dessa metodologia, é possível detectar uma enzima específica do gênero Lactococcus, a PepD, que sendo uma peptidase intracelular, é utilizada como um marcador de lise. Assim, se está enzima é detectada no extrato aquoso do queijo, pode-se afirmar que houve lise de alguma espécie de Lactococcus. Toda a metodologia será descrita em detalhes a seguir.

\section{Princípio}

O Immunoblotting é um método analítico que envolve 3 etapas principais: 1) migração de proteínas contidas em amostras de extratos aquosos de queijos, ou no citosol, de um microrganismo específico em um gel SDS-PAGE; 2) transferência do conteúdo protéico do gel para uma membrana de nitrocelulose através de Western-Blotting; 3) revelação das proteínas específicas através de uma reação imuno-enzimática pela ação da peroxidase e do $\mathrm{DAB}$, indicando, assim, a presença de enzimas de uma determinada espécie contidas no meio analisado.

\section{Descrição da técnica}

Após a separação das proteínas em gel SDS-PAGE, estas devem ser transferidas para uma membrana de nitrocelulose (diâmetro dos poros: $0.2 \mu \mathrm{m}$, Millipore, França). O gel SDS-PAGE é lavado rapidamente em água destilada e colocado em seguida numa solução de transferência (Tris-base $48 \mathrm{mM}$, glicina 39 mM, SDS 1,3 M em solução de metanol $20 \%(\mathrm{v} / \mathrm{v}))$, durante 5 minutos. Após este período, monta-se um camadas com o gel e a membrana de nitrocelulose, intercalando-se com papeis de filtro e esponjas, segundo o esquema abaixo (Figura Anexo B1). 


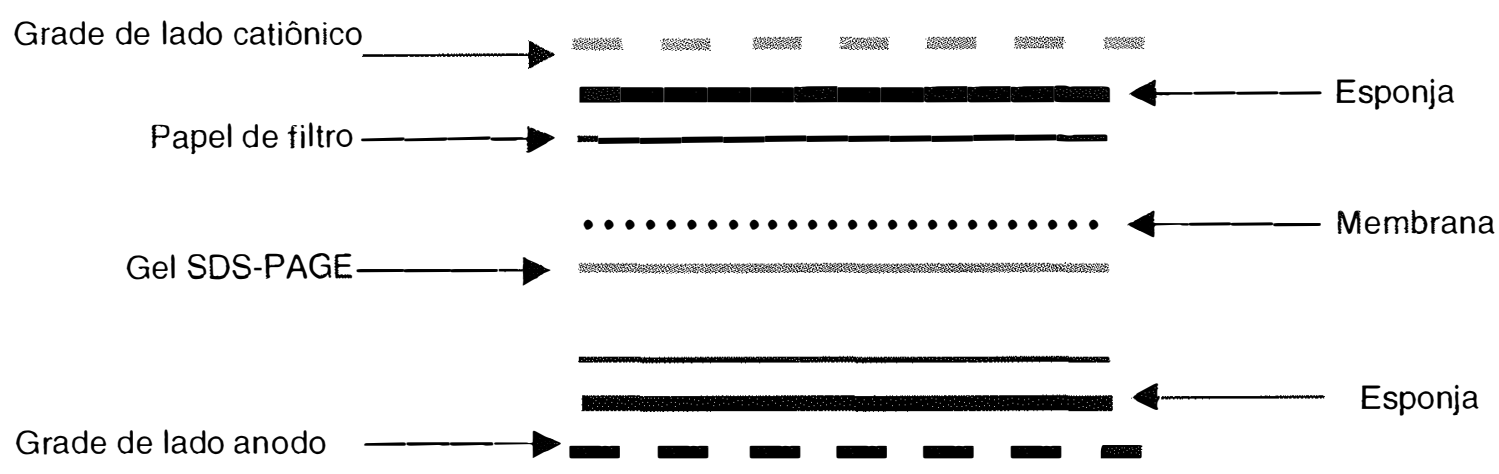

Figura Anexo B1 - Desenho esquemático da montagem do sistema de Western-Blotting para transferência de proteínas para membrana de nitrocelulose.

Após o sistema ser montado, a grade é colocada dentro da cuba de transferência (Trans-Blot, Biorad) de forma que a corrente elétrica passe do lado negativo para o positivo e as proteínas que se encontram separadas por tamanho no gel, possam ser transferidas para a membrana. A transferência é feita à amperagem constante $(250 \mathrm{~mA})$ durante uma hora e quinze minutos. Terminada a operação, a membrana é recuperada e incubada por 5 minutos numa solução de vermelho Ponceau $(0,2 \%$ de vermelho Ponceau em ácido tricloroacético à $0,8 \%$ ). Esta é uma coloração reversível que, em seguida à incubação, é lavada rapidamente em água destilada, até que todo o excesso do colorante da membrana seja retirado. Esta etapa é feita somente para visualizar se as proteínas foram transferidas de maneira adequada e identificar os marcadores de peso molecular conhecidos. O gel é descartado.

A membrana é, então, lavada 3 vezes, durante 10 minutos, em uma solução de PBS-Tween (Tween à 0,05\% em solução de PBS) e mais 10 minutos em uma solução de PBS 1x (diluição 1/10 de uma solução-mãe de PBS 10 vezes concentrada $(\mathrm{NaCl} 137 \mathrm{mM}$; $\mathrm{KCl} 2.7 \mathrm{mM} ; \mathrm{KH}_{2} \mathrm{PO}_{4} 1.5 \mathrm{Mm} ; \mathrm{Na}_{2} \mathrm{HPO}_{4}, 2 \mathrm{H}_{2} \mathrm{O} 8.1 \mathrm{mM}$ )). O próximo passo, é a incubação da membrana em uma solução de BSA (Bovine Serum Albumin, Sigma) à 1\% durante 1 hora, sob agitação. Seguem-se 3 lavagens de 10 minutos em PBS- Tween e a última uma em solução de PBS 1x. A membrana é, então, colocada na solução contendo o $1^{\circ}$ anticorpo (Acl) em PBS-Tween (concentração de 1/2500 para Lactococcus) durante 1 hora sob agitação lenta (ou durante uma noite, à $4^{\circ} \mathrm{C}$, sem agitação). Este anticorpo $\mathrm{Acl}$ é um soro dirigido contra uma proteína específica ou citosol inteiro, dependendo da espécie em estudo. 
A próxima etapa consiste novamente em efetuar 3 lavagens sucessivas em PBS-Tween e uma em PBS $1 \mathrm{x}$ durante 10 minutos cada uma.

Segue-se, então, a incubação da membrana em contato com o $2^{\circ}$ Anticorpo (ou Ac2) em solução à 1/2500 em PBS-Tween, durante 1 hora sob agitação lenta. Este anticorpo é uma Imunoglobulina anti-coelho do tipo G. O Ac2, que estando acoplado à peroxidase, reconhecerá especificamente o Acl. Graças à essa enzima, as proteínas podem ser visualizadas no momento da revelação (Figura Anexo B2). A membrana é finalmente lavada mais 2 vezes em PBS-Tween e uma outra em PBS 1x durante 10 minutos.

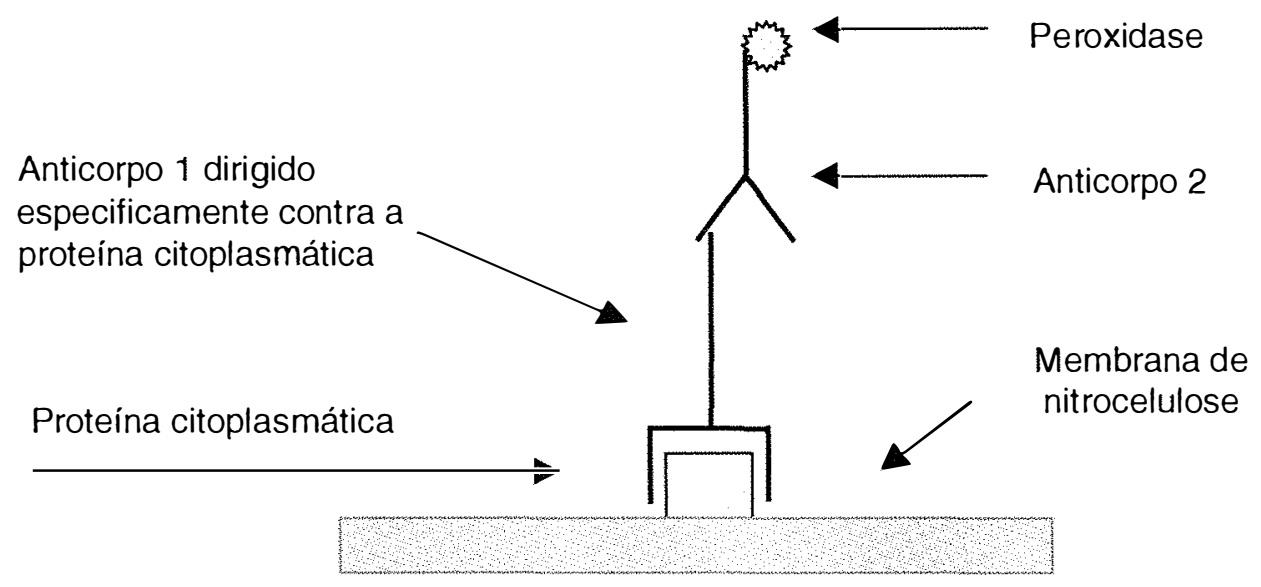

Figura Anexo B2 - Ilustração esquemática da reação imunológica para a visualização de proteínas específicas.

A finalização dessa metodologia ocorre com a revelação da membrana. A solução de revelação compõem-se de solução de $\operatorname{DAB}(3,3)$ diaminobenzidina tetrahidroclorido, Interchim) à $1 \mathrm{mg} / \mathrm{ml}$, em um tampão Tris $50 \mathrm{mM}, \mathrm{pH}$ 7.2. Esta solução de DAB deve ser misturada volume à volume com uma solução de água oxigenada à $0.02 \%$. Esta solução de revelação deve ser preparada extemporaneamente e depositada sobre a membrana. As bandas, correspondentes à proteína específica detectada pelo Anticorpo 1, surgem dentro de alguns minutos. Uma vez a revelação sendo considerada satisfatória, retira-se a solução de revelação e adiciona-se água fria várias vezes, a fim de bloquear a reação. A membrana revelada deve ser seca em papel absorvente, guardada sob o abrigo de luze registrada por meio de fotografia ou scaner. 


\section{ANEXO C}

\section{Dados suplementares referentes ao artigo:}

"Impacto de células rompidas de lactococos ou propionibactéria através de homogeneização na maturação de queijos Ultrafiltrados: extensão da proteólise e perfil em CG-MS”

(Capítulo 4) 


\section{HomogenEIZAdOR-PILOTO À ALTA PRESSÃo UTILIZADO NO ROMPIMENTO DE CÉLULAS BACTERIANAS PARA OBTENÇÃO DE EXTRATOS INTRACELULARES}

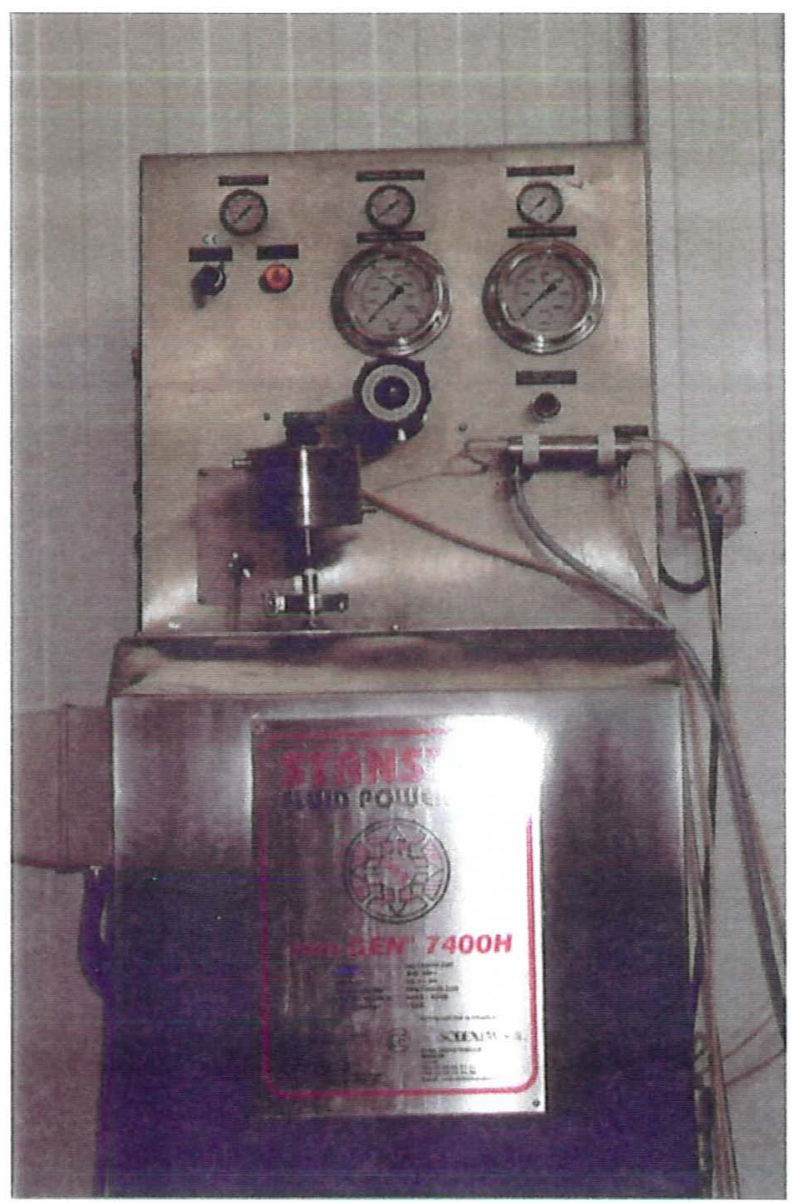

Foto Anexo C1 - Equipamento-piloto "Stasted fluid power homogeneizer Ltda." (Nm-GEN 7400H, comercializado por Sodexim, France) utilizado nos experimentos de rompimneto de células bacterianas, para a obtenção de extratos intracelulares.

Princípio de funcionamento: aplicação de 1 a $300 \mathrm{MPa}$ de pressão em um cilindro de capacidade de 70 a $80 \mathrm{ml}$, seguindo-se de uma descompressão instantânea. Essa diferença brusca de pressão é responsável pela ruptura de células dos microrganismos implicados. A temperatura no interior do equipamento pode atingir 30 à $35^{\circ} \mathrm{C}$ à

Foto Anexo C2 - Detalhe do Homogeneizador, mostrando o local de entrada do líquido a ser tratado (1); a válvula de controle da pressão (2); o mostrador da pressão (3) e o local de coleta do líquido homogeneizado (4).

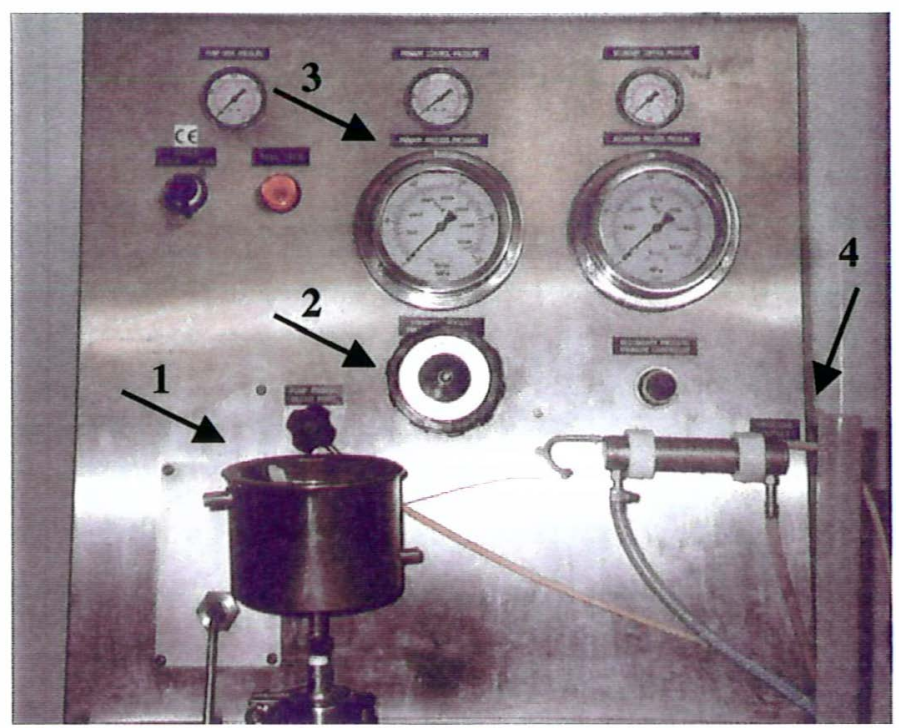




\section{ILUSTRAÇÕES de ETAPAS dA FABRICAÇÃo de QUEIJOS UF-SAINT PAULIN}

\section{Equipamento de Ultrafiltração}

Foto Anexo C3 - Unidade Piloto equipada com membranas CARBOSEP Ml (Rhodia-Orelis, França), com poder de corte (cut-off) de $150 \mathrm{kDa}$ e superfície de $6,8 \mathrm{~m}^{2}$. Pertencente ao Laboratoire de Recherche de Technologie Laitière - Centro INRA de Rennes, França.
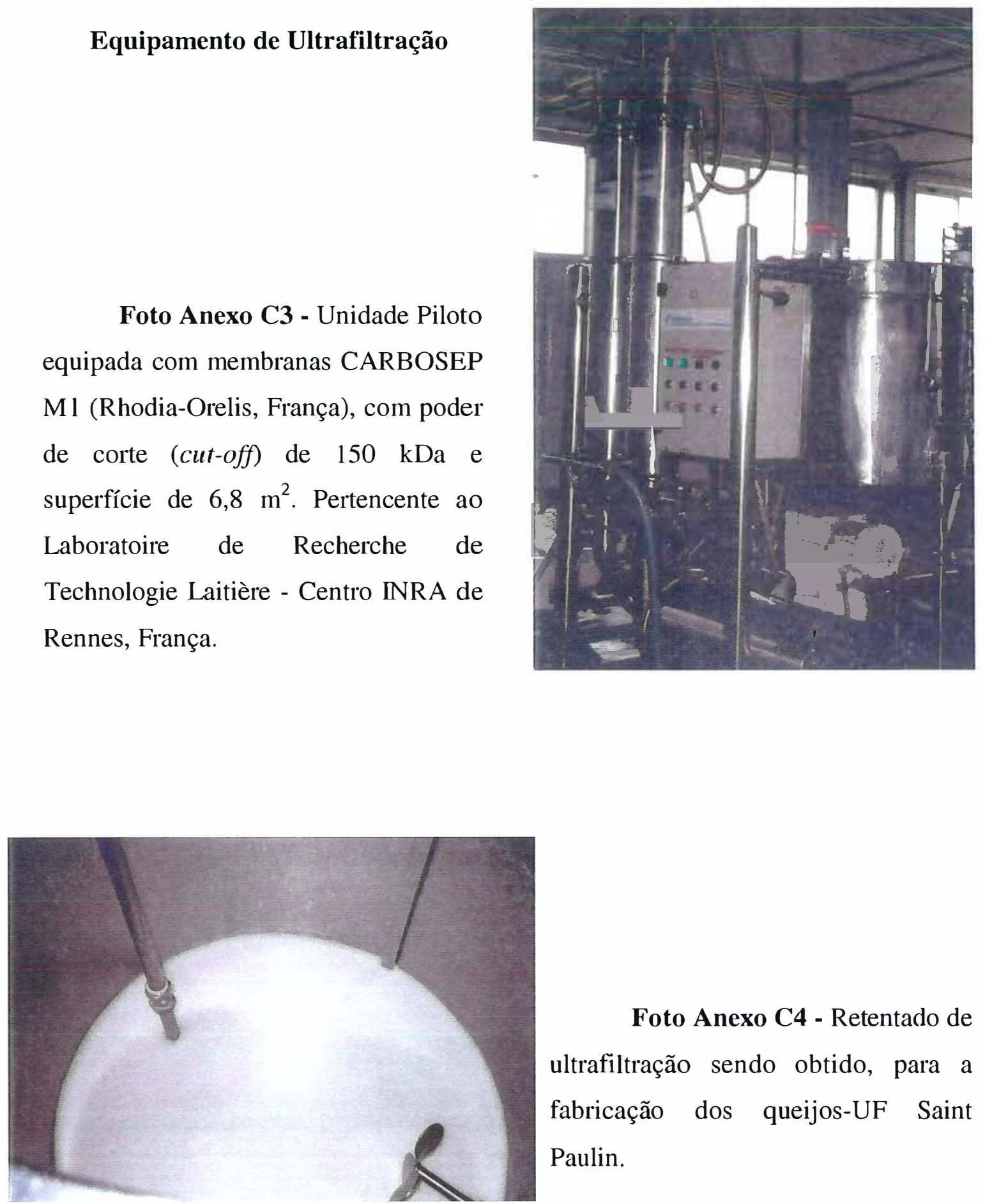

Foto Anexo C4 - Retentado de ultrafiltração sendo obtido, para a fabricação dos queijos-UF Saint Paulin. 


\section{ETAPas do Preparo dos QUeiJos UF-Saint PaUlin}

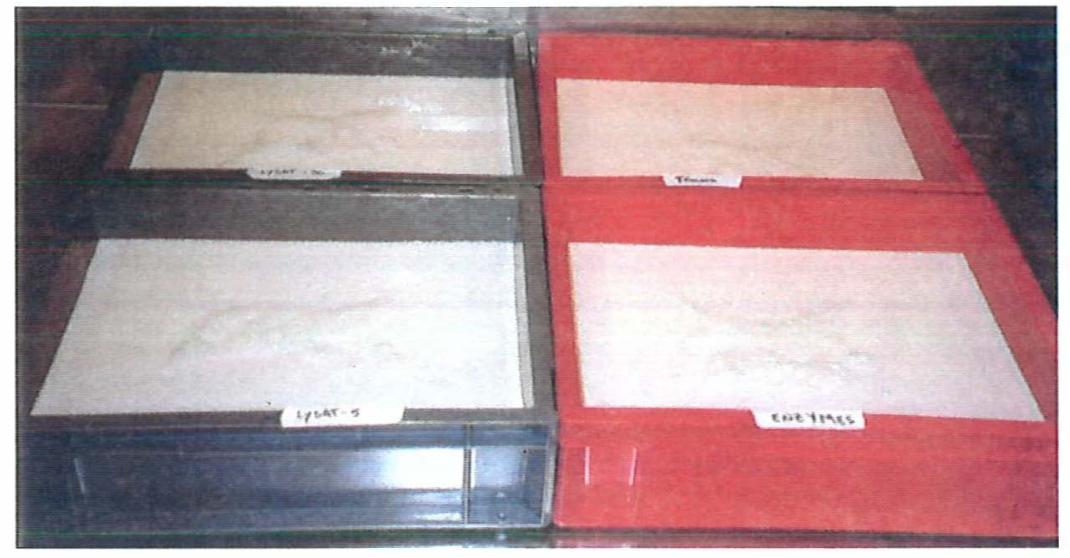

Foto Anexo C5 - Retentado de UF $(\mathrm{fc}=6)$ nas formas para endurecimento da massa e formação do queijo.

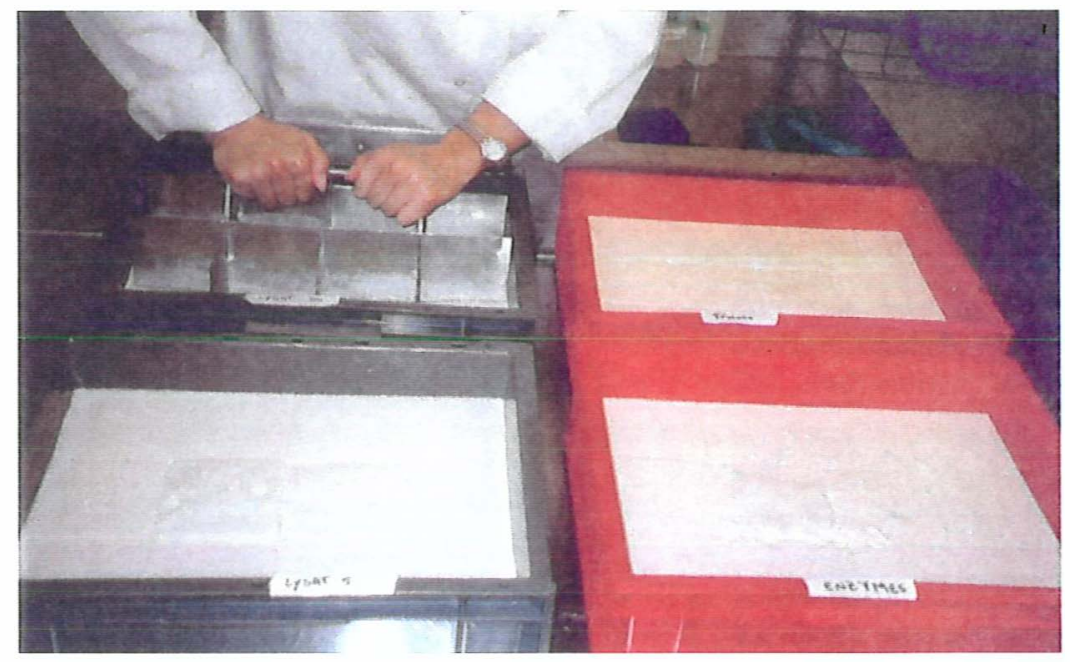

Foto Anexo C6 - Corte do retentado após o endurecimento da massa para a formação do queijo-UF Saint Paulin. 


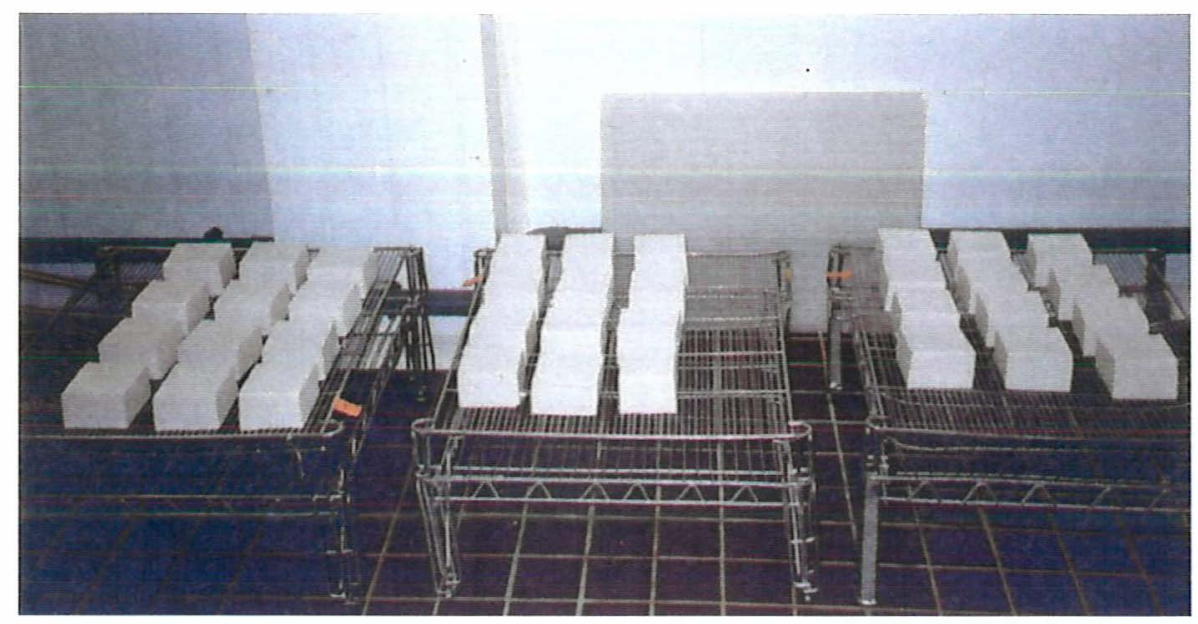

Foto Anexo C7 - Queijos-UF Saint Paulin na câmara a $12^{\circ} \mathrm{C}$, em D+1

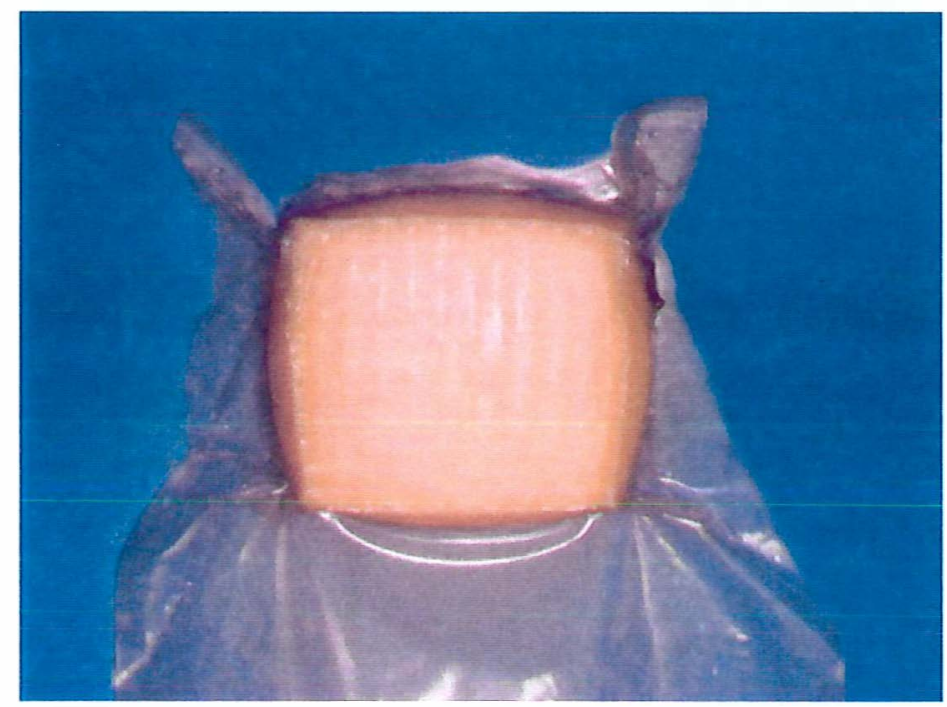

Foto Anexo C8 - Queijo-UF Saint Paulin maturado (D+45), embalado em saco plástico impermeável, à vácuo. 


\section{Immunoblotting - ENSAIO PROP}
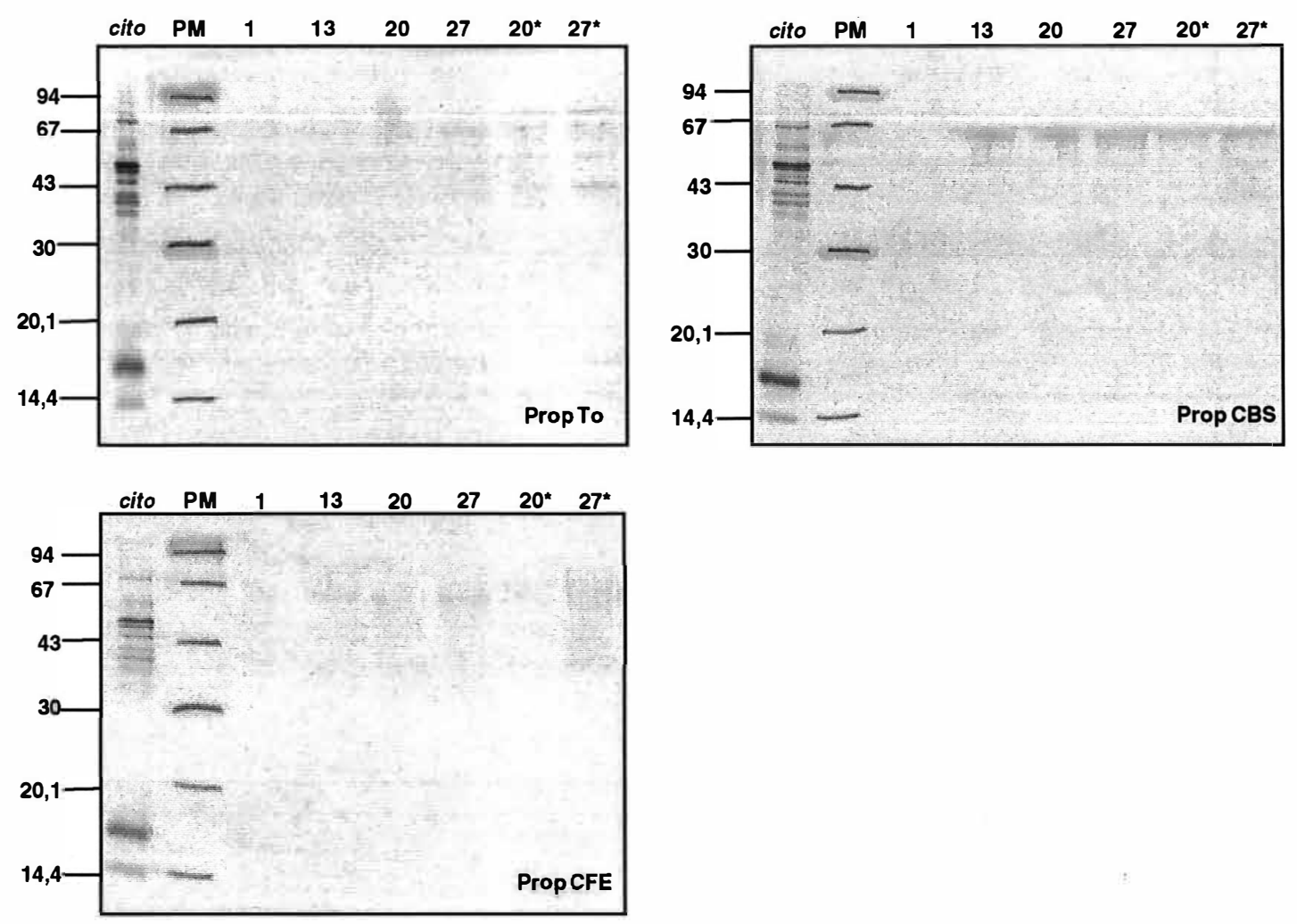

Blotting Anexo C9 - Immunoblotting de proteínas citoplasmáticas de Lactococcus nos queijos UF-Saint Paulin adicionados de extratos intracelulares de $P$. freudenreichii (CBS e CFE) e controle (To), durante a maturação a $12^{\circ} \mathrm{C}$ ou a $20^{\circ} \mathrm{C}$. O período de armazenamento dos queijos, em dias, está indicado acima de cada blotting. (* são os queijos sob $20^{\circ} \mathrm{C} ; \mathrm{PM}=$ Peso Molecular, $\mathrm{kDa}$; Cito = proteínas citoplasmáticas de Lactococcus lactis).

\section{Comentário:}

Demonstração de que a lise de Lactococcus sp. é muito fraca no queijo UF-Saint Paulin. 
Immunoblotting - ENSAIO LAC
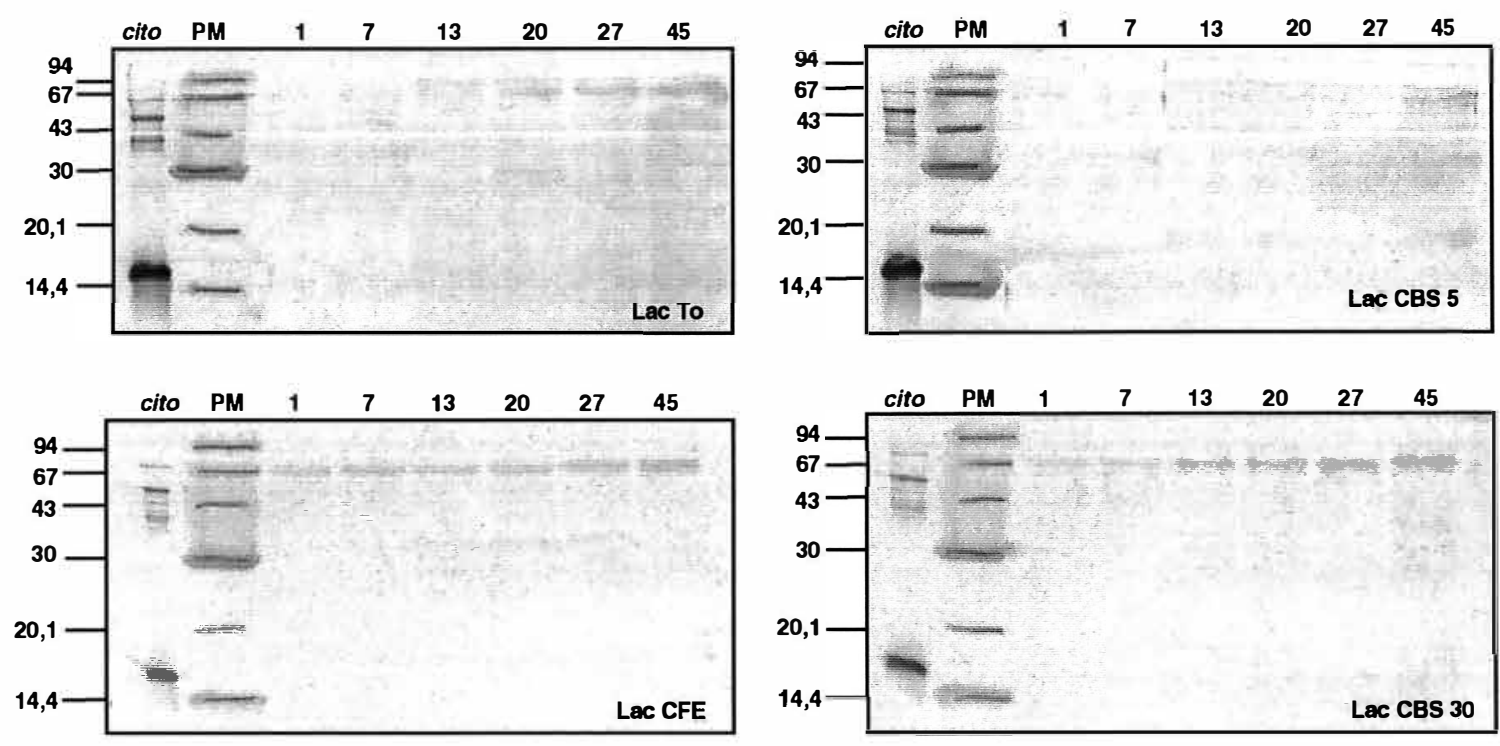

Blotting Anexo C10 - Immunoblotting de proteínas citoplasmáticas de Lactococcus nos queijos UF-Saint Paulin adicionados de extratos de Lactococcus sp. (CBS 5, CBS 30, $\mathrm{CFE}$ ) e controle (To), durante o armazenamento a $12^{\circ} \mathrm{C}$. O período de armazenamento dos queijos, em dias, está indicado acima de cada blotting (PM = Peso Molecular, kDa; Cito = proteínas citoplasmáticas de Lactococcus lactis).

\section{Comentário:}

Demonstração de que a lise de Lactococcus sp. é muito fraca no queijo UF-Saint Paulin. 


\section{Índice de Extensão da MATURAÇão (NCN/NT) - ENSAio ProP}

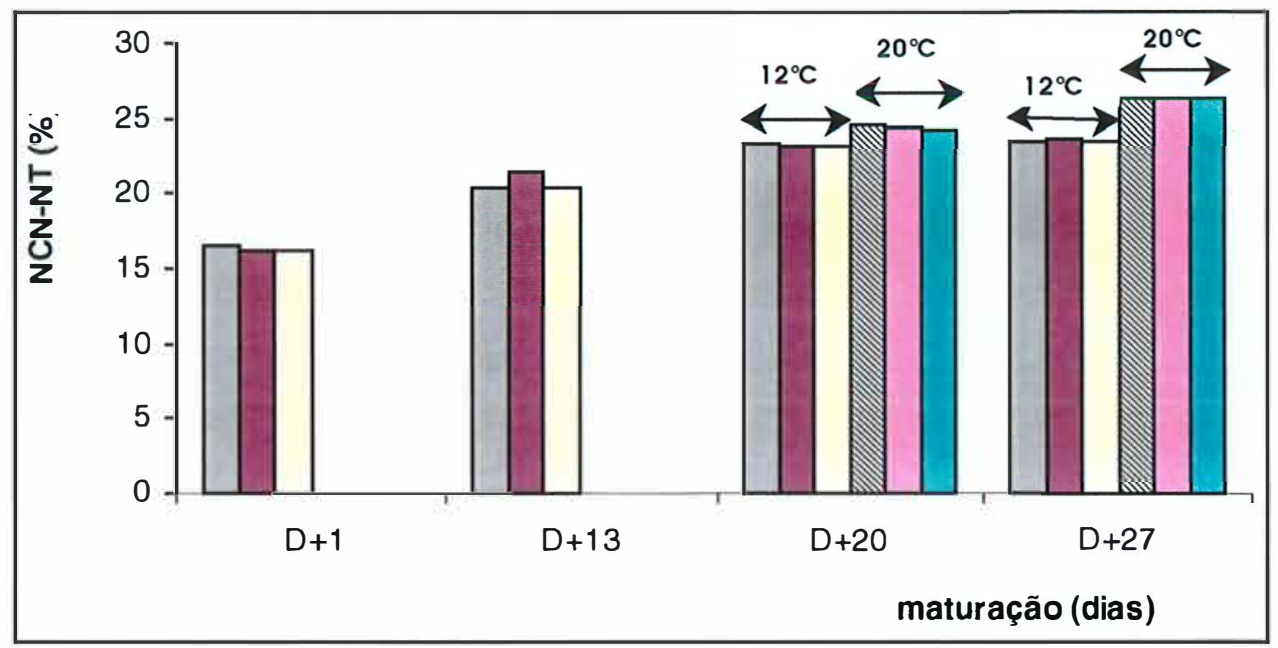

Gráfico Anexo C11 - Relações entre NCN e NT (\%) nos queijos-UF tratados com $P$. freudenreichii e maturados a $12^{\circ} \mathrm{C}\left(\square\right.$ Controle; $\square$ CBS; $\square$ CFE) ou a $20^{\circ} \mathrm{C}$ ( Controle; $\square$ CBS; $\square$ CFE).

Comentário: Não houve diferença entre os tratamentos. Observou-se somente evolução do índice de extensão da maturação da proteólise, mas não houve diferença entre os queijos tratados e o controle. 
SDS-PAGE - EnSAIo Prop

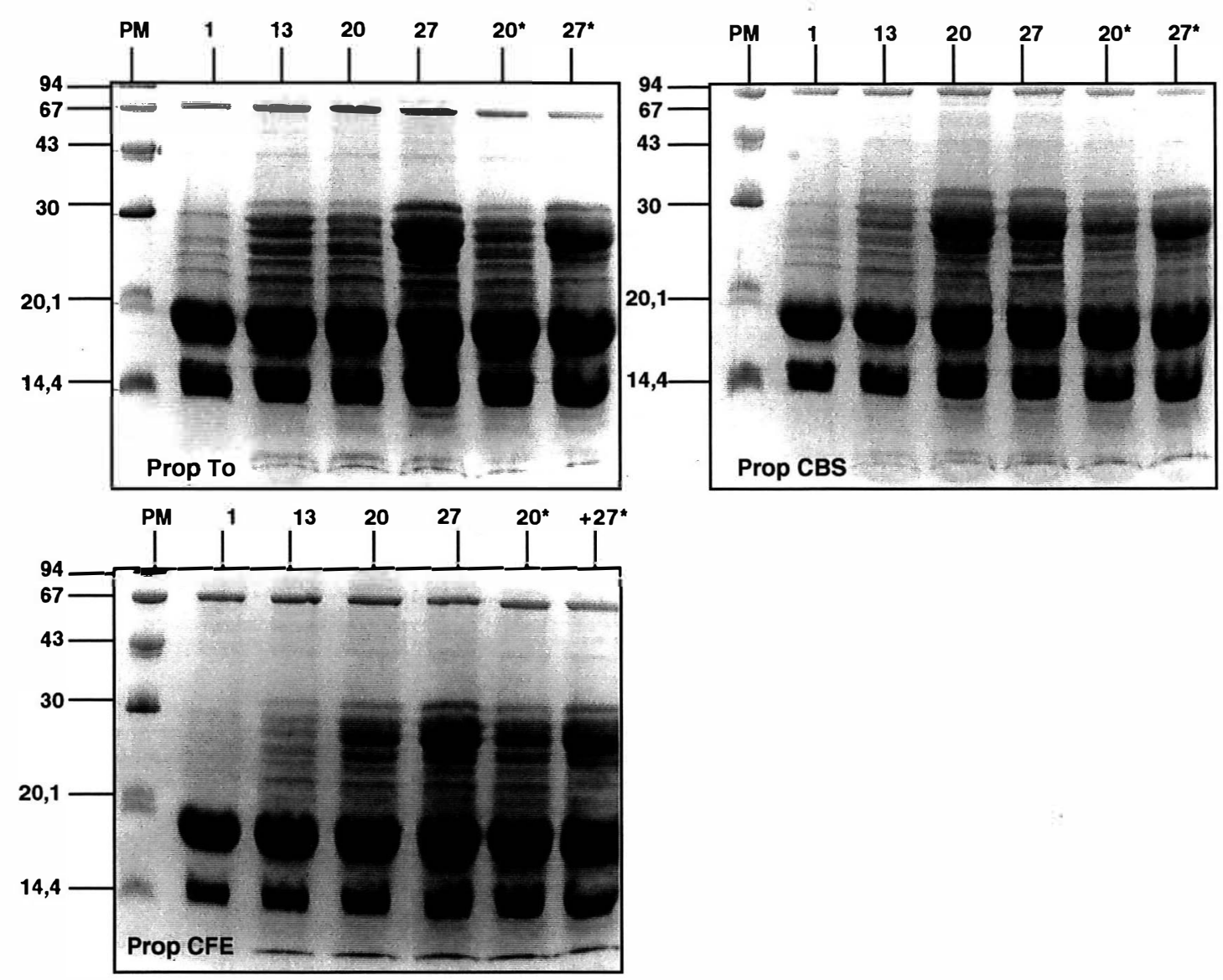

SDS-PAGE Anexo C12 - SDS-PAGE dos extratos aquosos de amostras do queijo-UF Saint Paulin adicionados de extratos intracelulares de P. freudenreichii (CBS, CFE) e controle (To), tomadas durante a maturação a $12^{\circ} \mathrm{C}$ ou a $20^{\circ} \mathrm{C}$, mostrando os perfis de proteínas. O tempo de maturação dos queijos, em dias, está indicado acima de cada gel. (* são os queijos sob $20^{\circ} \mathrm{C} ; \mathrm{PM}=$ Peso Molecular, $\mathrm{kDa}$ )

Comentário: Não houve diferença de perfis de proteínas entre os tratamentos. 
ÍNDICES DE EXTENSÃO E PROFUNDIDADE DA PROTEÓLISE - ENSAIO LAC

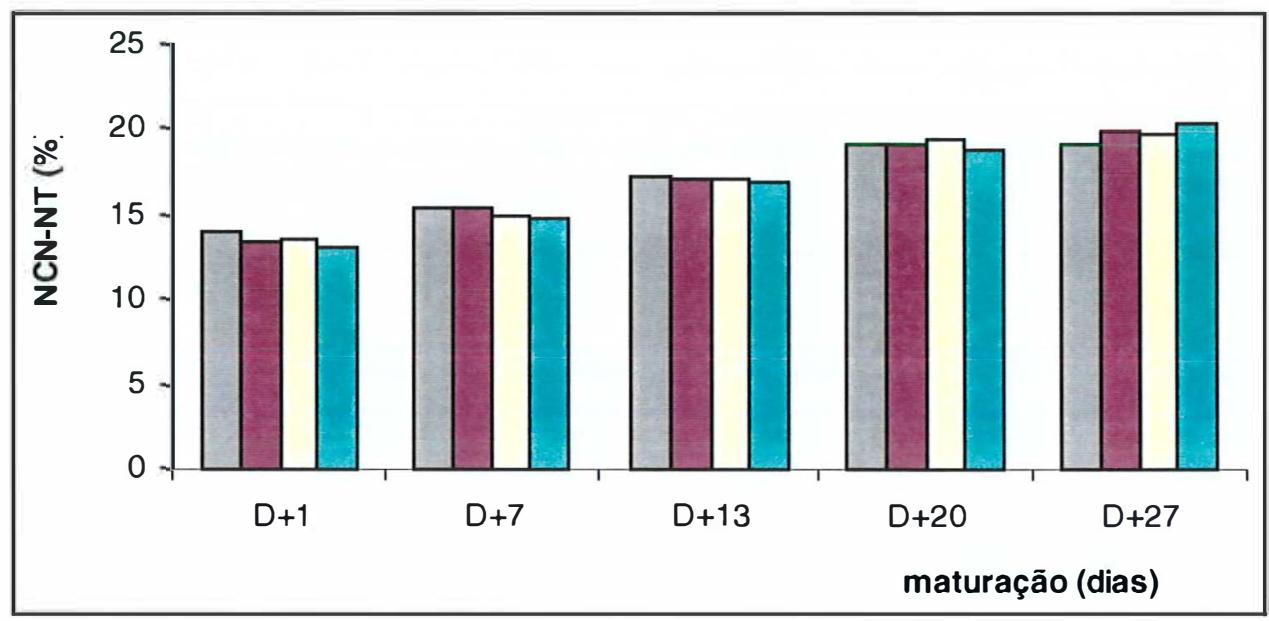

Gráfico Anexo C13 - Índice de extensão da maturação (NCN / NT \%) nos queijos-UF tratados com extratos intracelulares de Lactocccus sp. e maturados a $12^{\circ} \mathrm{C}(\square$ Controle; $\square$ CBS $5 ; \square$ CBS $30 ; \square$ CFE).

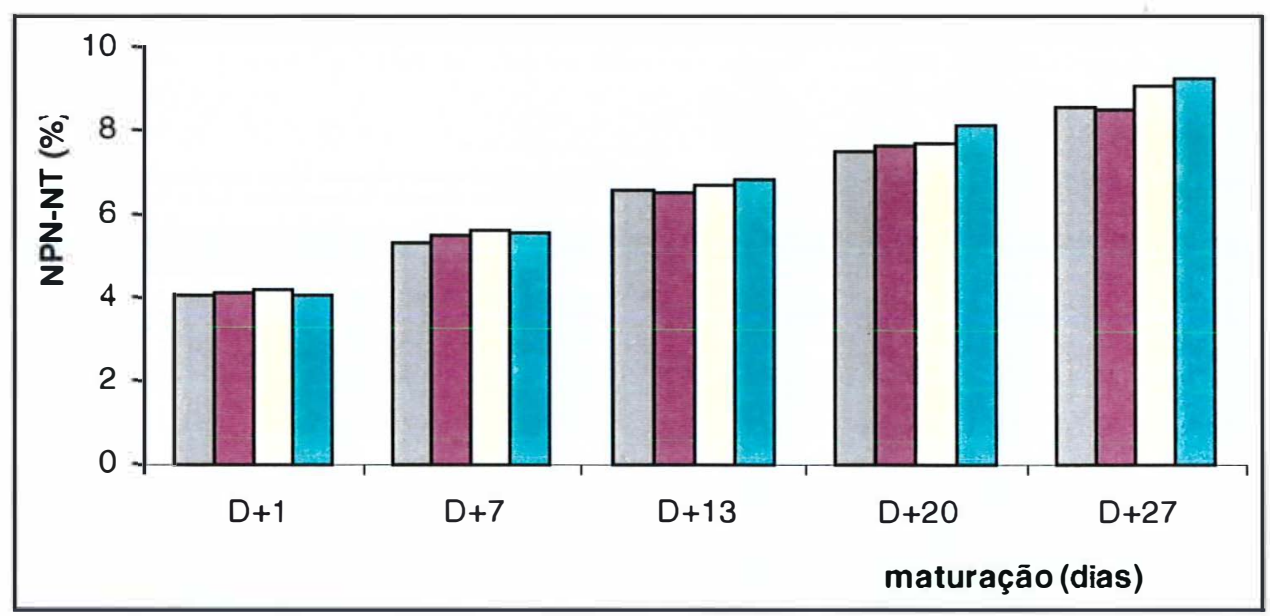

Gráfico Anexo C14 - Índice de profundidade da maturação (NPN/ NT $\%)$ nos queijos-UF tratados com extratos intracelulares de Lactocccus sp. e maturados a $12^{\circ} \mathrm{C}(\square$ Controle; $\square$ CBS $5 ; \square$ CBS 30; $\square$ CFE). 
SDS-PAGE - ENSAIO LAC
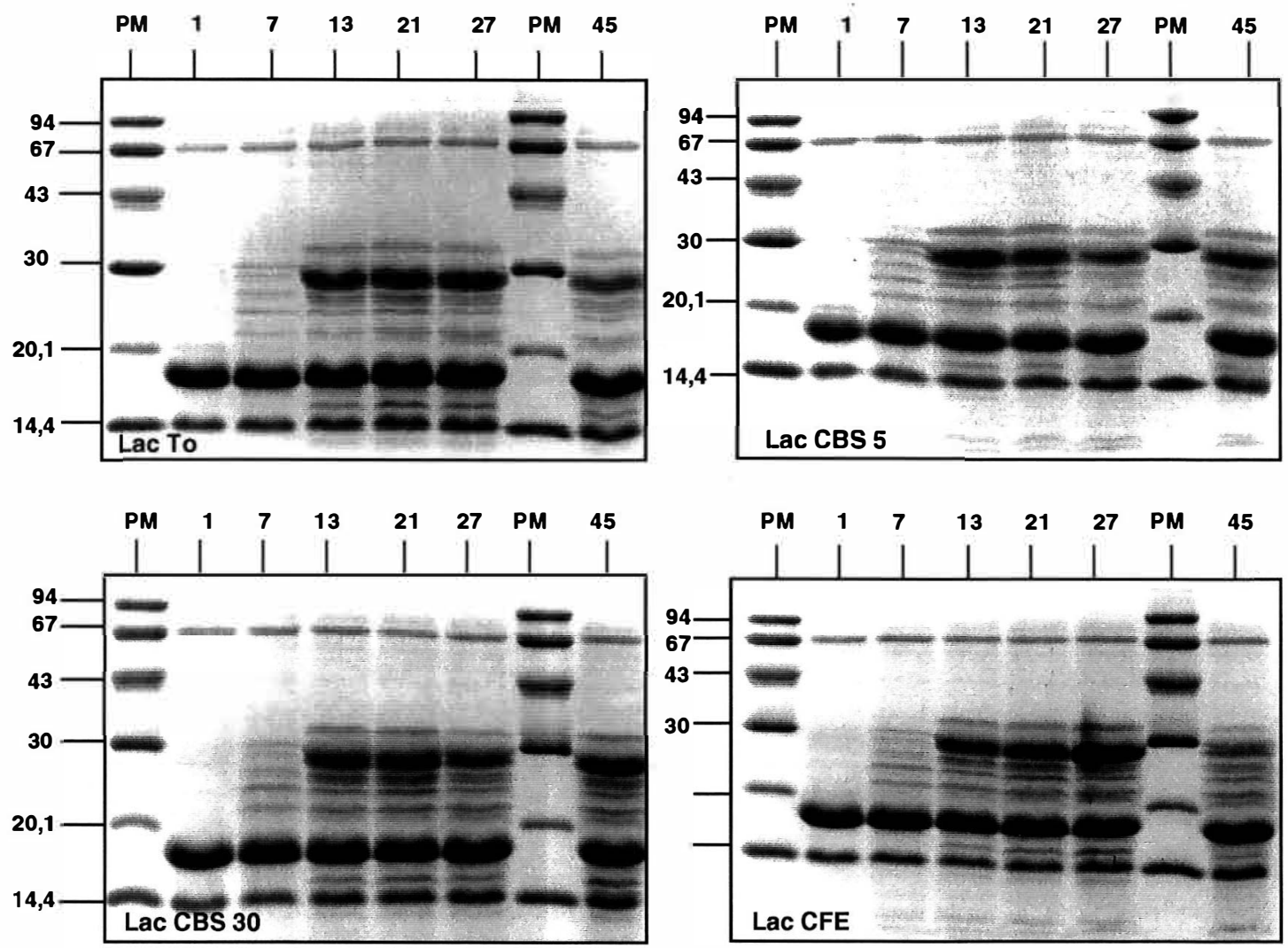

SDS-PAGE Anexo C15 - SDS-PAGE dos extratos aquosos de amostras do queijo UFSaint Paulin adicionado de extratos intracelulares de Lactococcus sp., mostrando os perfil de proteínas, durante a maturação a $12^{\circ} \mathrm{C}$. Tratamentos: Controle; CBS 5; CBS 30; CFE. A massa molecular padrão está indicada ao lado esquerdo de cada figura. (PM = peso molecular, $\mathrm{kDa}$ ). Os dias em que foram tomadas as amostras, após a fabricação dos queijos, estão indicados na extremidade de cada gel.

Comentário: Não houve diferença de perfis de proteínas entre os tratamentos. 


\section{ANEXO D}

\section{Dados suplementares referentes ao artigo:}

"Comportamento de lactococos com características autolíticas distintas em queijo Minas Frescal empregando-se Microfiltração e Ultrafiltração" (Capítulo 5) 


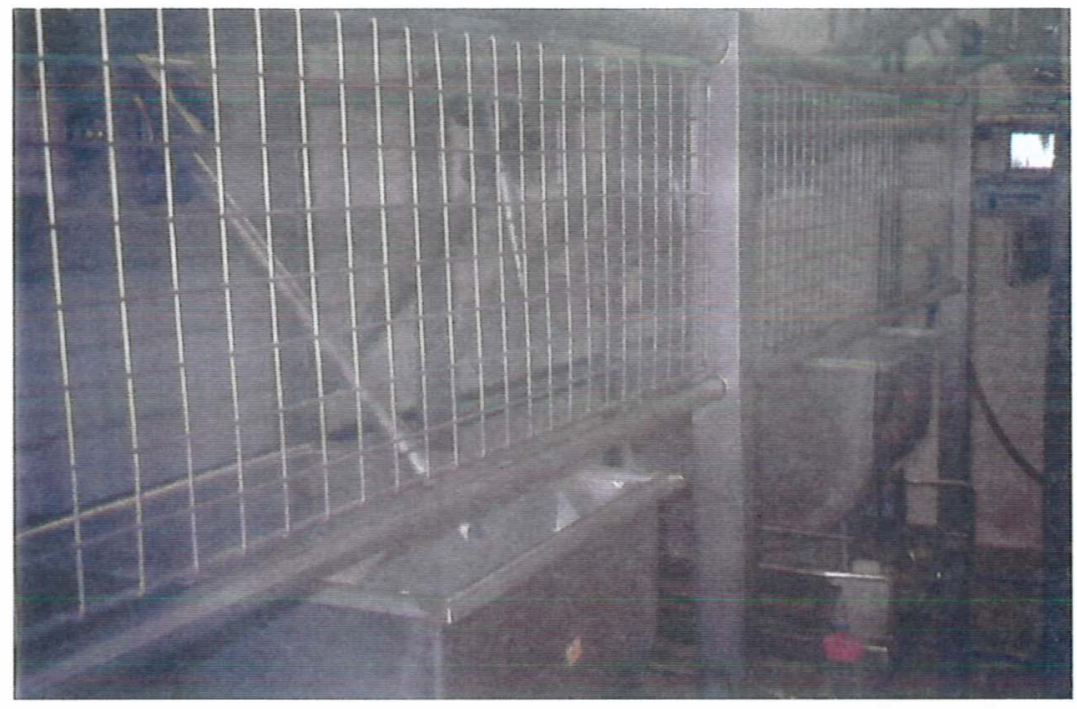

Foto Anexo D1 - Equipamento-piloto semi-automático adaptado para a fabricação de queijos de massa mole (Tecnal, Niort, França), com duas cubas de fabricação.

Momento da coagulação da massa.

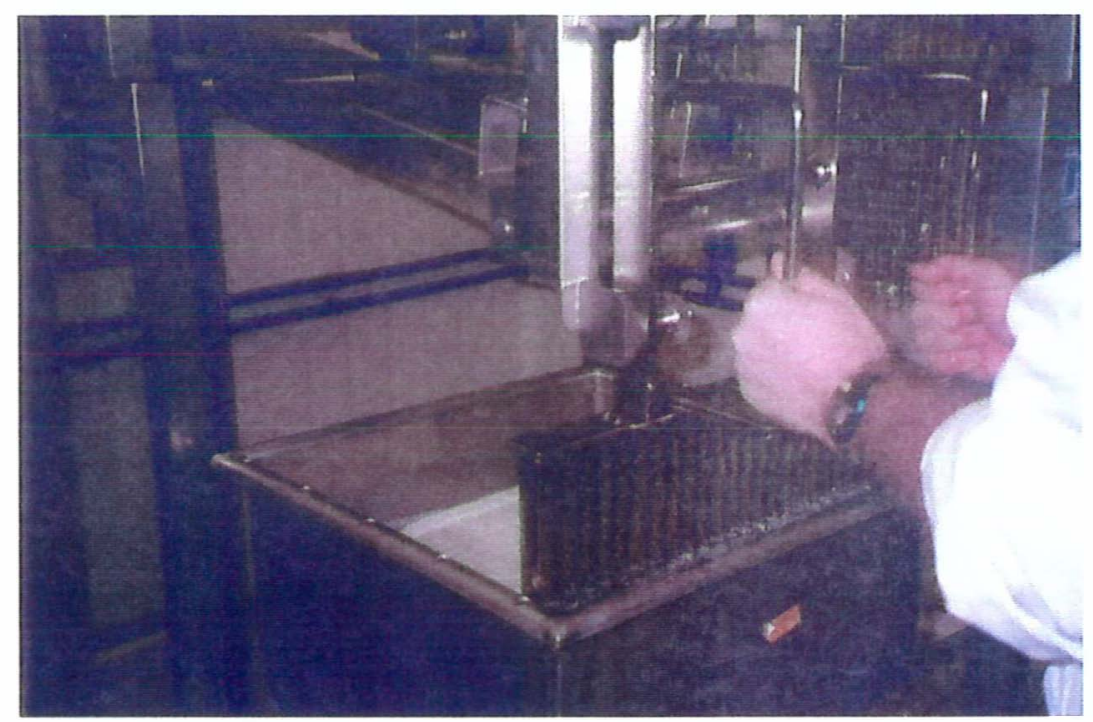

Foto Anexo D2 - Corte da massa (queijo Minas Frescal tradicional) 


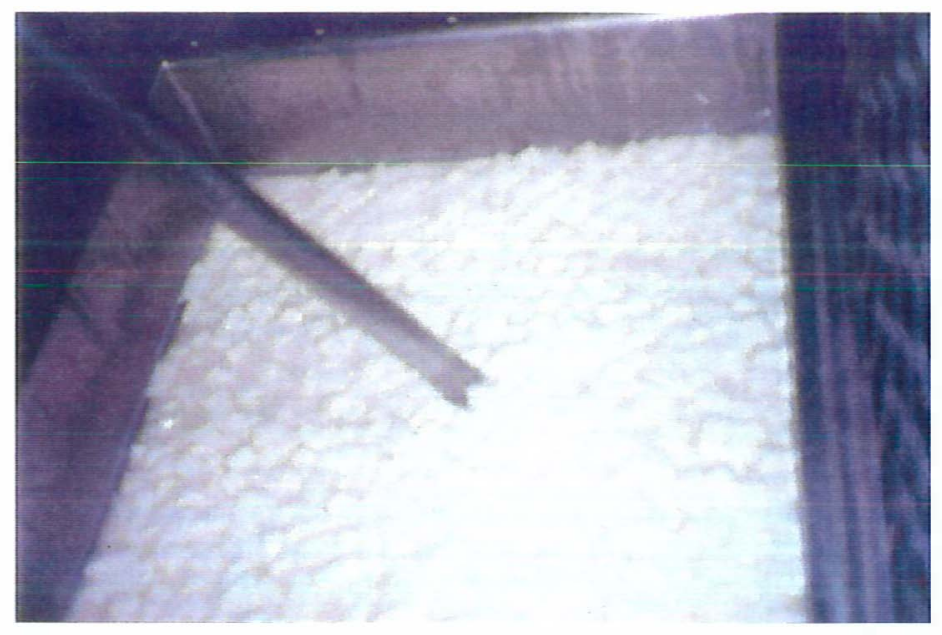

Foto Anexo D3 - Mexedura da massa, durante a fabricação do queijo Minas Frescal tradicional

Foto Anexo D4 - Enformagem semiautomda massa (queijo Minas Frescal tradicional).

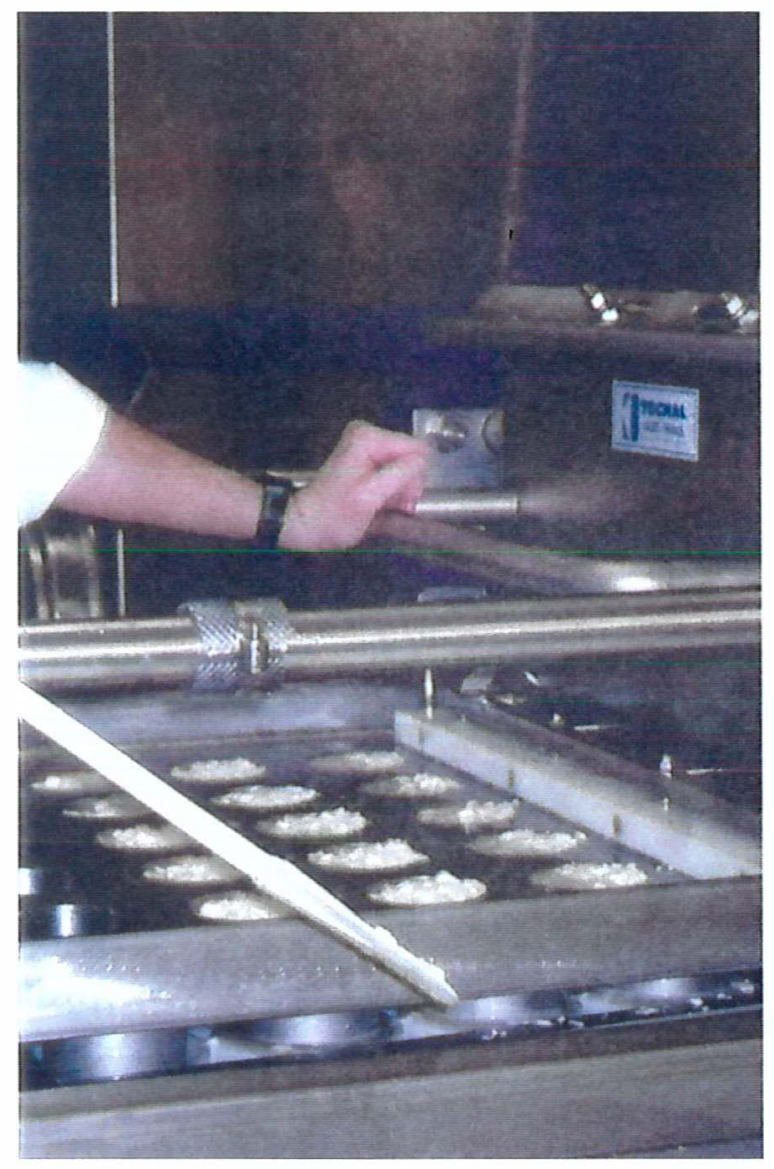


QUEIJOS MINAS FRESCAL TRADICIONAIS SOB ARMAZENAMENTO A $5^{\circ} \mathrm{C}$ À D+14

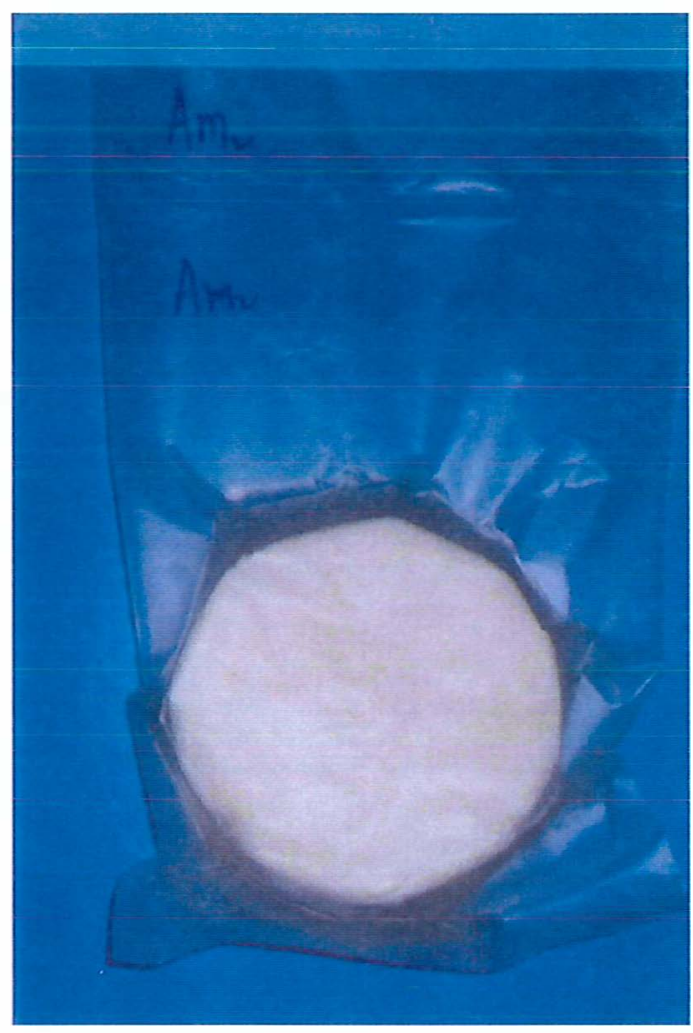

Foto Anexo D5 - Queijo Minas Frescal tradicional, fabricado com a linhagem autolítica Lactococcus lactis subsp. cremoris AM2 à $\mathrm{D}+14, \mathrm{a} 5^{\circ} \mathrm{C}$.

Trad AM2

Foto Anexo D6 - Queijo Minas Frescal tradicional, fabricado com a linhagem nãoautolítica Lactococcus lactis subsp. cremoris AM2-C

à $\mathrm{D}+14$, a $5^{\circ} \mathrm{C}$.

Trad AM2-C

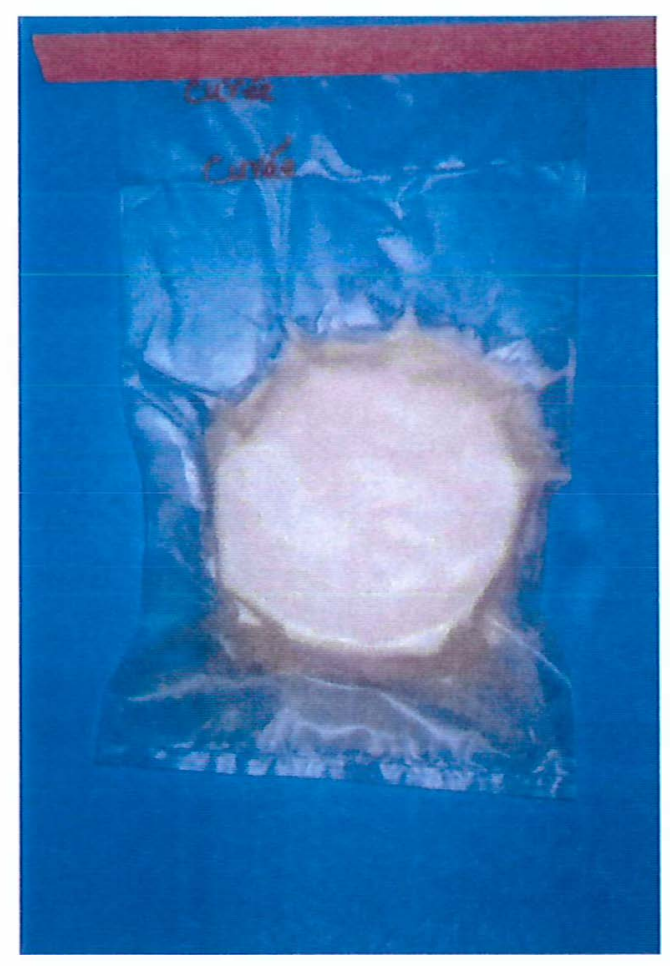


EtaPAS de FabricaÇão do QUEIJO Minas Frescal POR UltrafiltraÇão

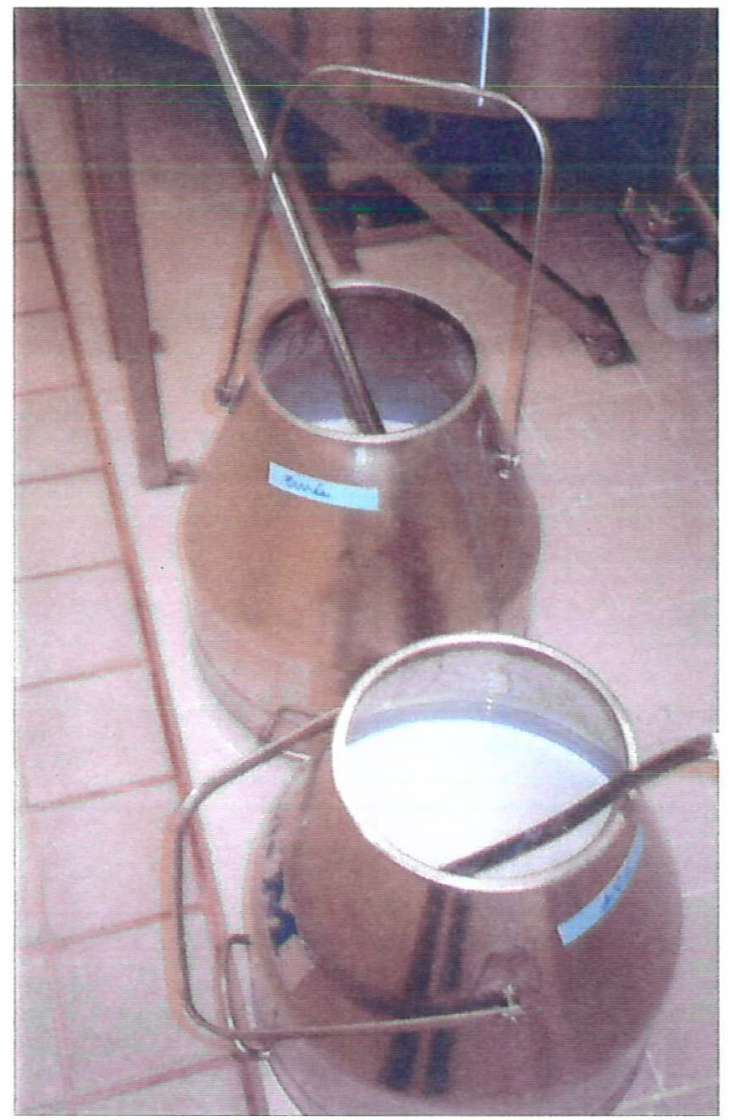

Foto Anexo D7 - Retentados de UF $\left(\mathrm{fc}=5\right.$ ) durante a fermentação a $30^{\circ} \mathrm{C}$, com as linhagens de Lactococcus lactis subsp. cremoris AM2 ou AM2-C, para a obtenção dos queijos-UF Minas Frescal

UF AM2 e UF AM2-C

Foto Anexo D8 -

Queijos-UF Minas

Frescal durante a coagulação em embalagens plásticas

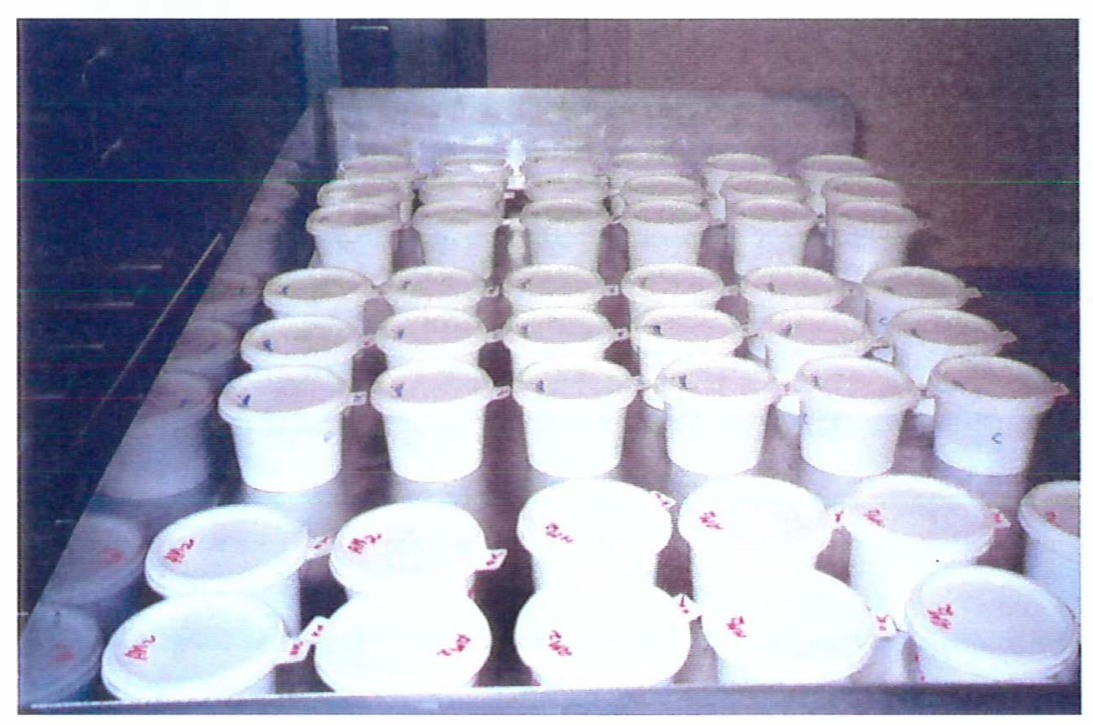




\section{ANEXO E}

Verificação de lise Lactococcus sp. de queijos-UF do mercado francês através de Immunoblotting 


\section{LISE DE Lactococcus Sp. EM QUEIJOS-UF DO MERCADO FRANCÊS}

\section{Objetivo:}

Estudar a lise de Lactococcus sp. em alguns queijos do mercado francês: Brebicet, Florette, Pavé d'Affinois e Le Brin, fabricados por UF utilizando a técnica de Immunoblotting.

\section{Finalidade:}

Verificar se a lise de Lactococcus sp. também ocorre de forma pouco intensa em queijos comerciais e, assim, sustentar as observações feitas nos queijos-UF experimentais desse trabalho (Saint Paulin e Minas Frescal). Os queijos comerciais analisados estão ilustrados na Fotografia a seguir.

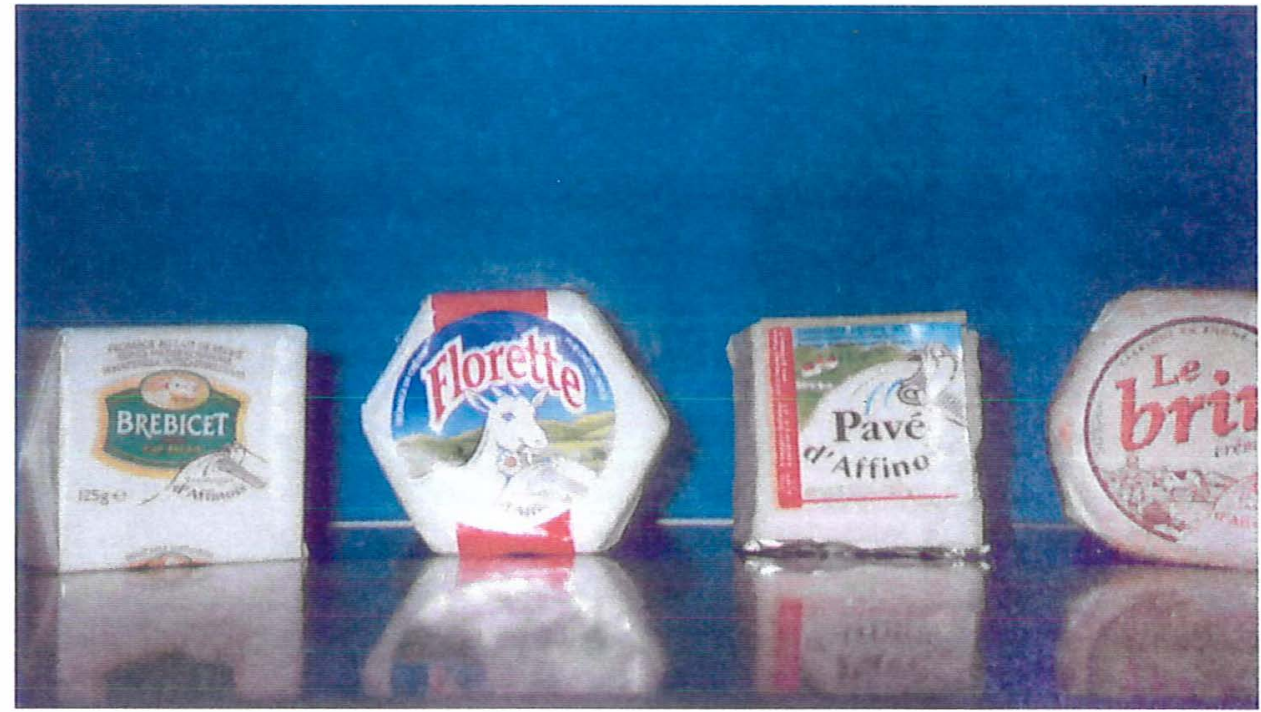

Legenda: Da esquerda para a direita: Brebicet; Florette; Pavé d'Affinois; Le Brin. 
Características de 4 queijos-UF do mercado francês

\begin{tabular}{lcccc}
\hline & Florette & Brebicet & Pavé d'Affinois & Le Brin \\
\hline Leite empregado & cabra & ovelha & vaca & vaca \\
Peso & $125 \mathrm{~g}$ & $125 \mathrm{~g}$ & $150 \mathrm{~g}$ & $150 \mathrm{~g}$ \\
MG/EST & $45 \%$ & $50 \%$ & $45 \%$ & $50 \%$ \\
Flora microbiana & mesofílica & $\begin{array}{c}\text { mesofílica }+ \\
\text { outras }\end{array}$ & termofílica & termofílica \\
\hline
\end{tabular}

RESULTADOS DA ANÁLISE DO PERFIL DE PROTEÍNAS EM GEL DE ELETROFORESE DOS 4 QUEIJOS-UF DO MERCADO FRANCÊS.

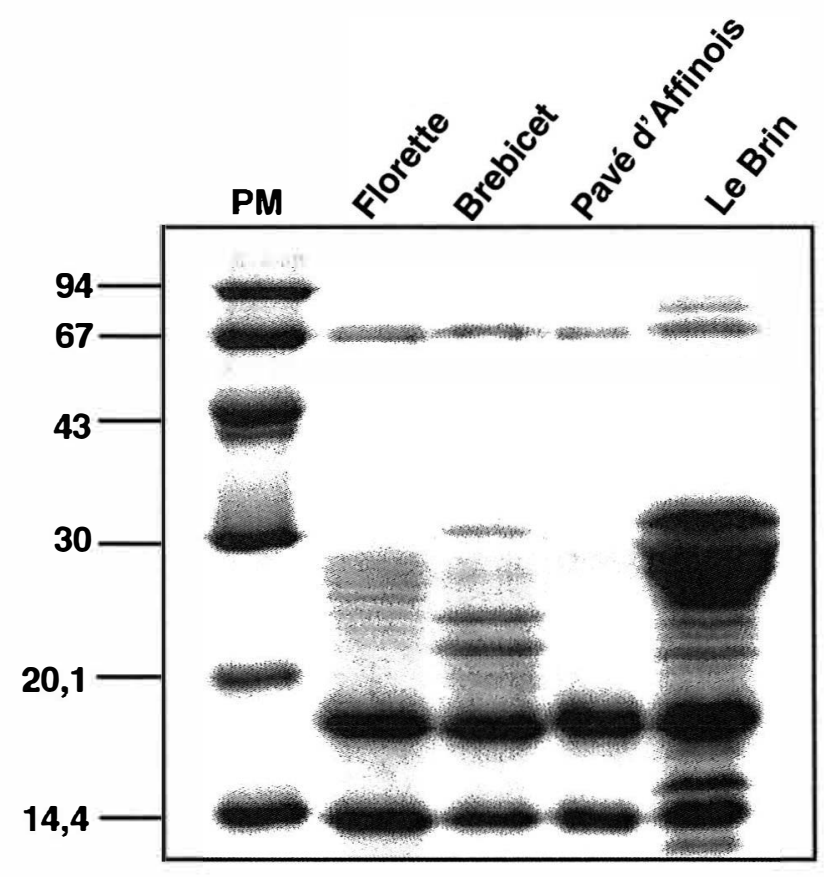

\section{Comentários:}

O perfil de proteínas em SDS-PAGE mostra as diferenças entre os 4 queijos-UF, advindas principalmente do leite do qual foram fabricados e do tipo de microrganismos envolvidos na maturação. 
ANÁLISE DA LISE DE Lactococcus Sp. EM QUEIJOS-UF DO MERCADO FRACÊS, ATRAVÉS DE IMMUNOBLOTTING

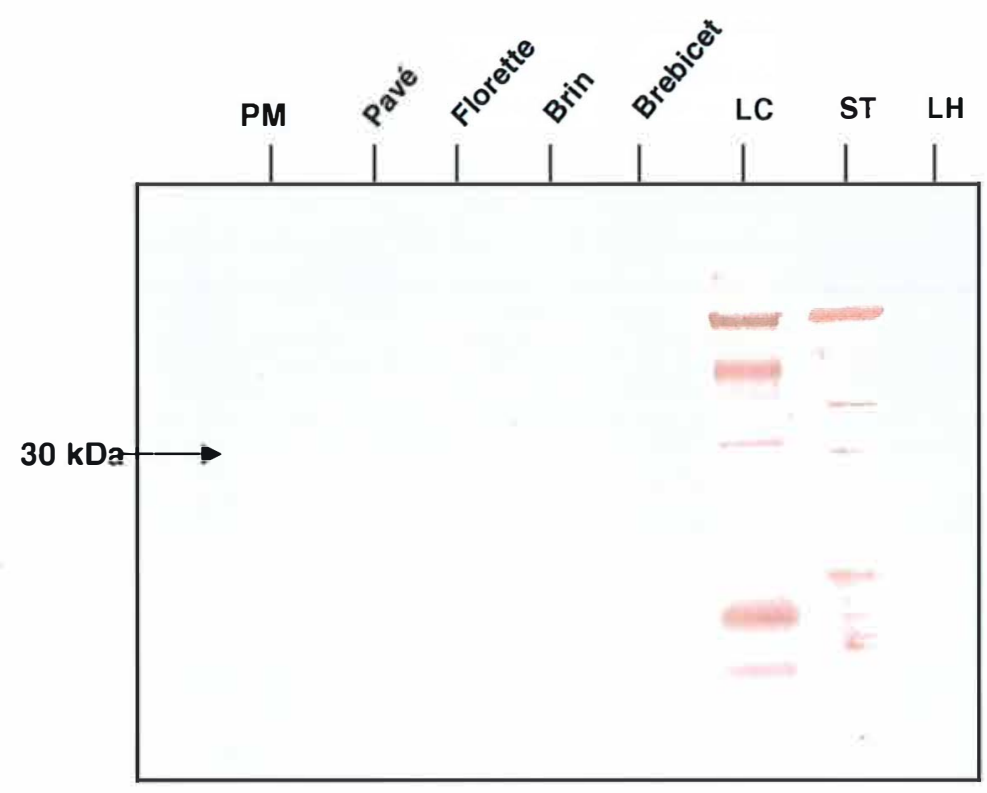

Immunoblotting de proteínas citoplasmáticas de Lactococcus (LC), Streptococcus (ST) e Lactobacillus (LH) nos queijos-UF comerciais franceses: Pavé d'Affinois, Florette, Le Brin e Brebicet. $(30 \mathrm{kDa}=$ Peso Molecular usado como marcador).

Comentário: Através do Immunoblotting acima apresentado, demonstrou-se que a lise de Lactococcus sp. também é ausente em queijos-UF do mercado francês, devido a não aparição de bandas. Esse resultado comprova aqueles observados quanto a ausência de lise nos queijos-UF estudados neste trabalho, o Saint Paulin e o Minas Frescal. 


\section{REFERÊNCIAS BIBLIOGRÁFICAS}

ALBUQUERQUE, L.C.; CASTRO, M.C.D. Queijos finos: origem e tecnologia estatística do mercado de leite e queijos. Juiz de Fora: EPAMIG, 1995. 218p.

ANDREWS, A.T. Breakdown of caseins by proteinases in bovine milks with high somatic cell counts arising from mastitis or infusion with bacterial endotoxin. Journal of Dairy Research, v.50, p.57-66, 1983.

ASSOCIATION FRANÇAISE DE NORMALISATION. Directives générales pour le dénombrement des Staphylococcus aureus: méthode par comptage des colonies Norme Française V 08-014. Paris: AFNOR, 1984. 2p.

ASSOCIATION FRANÇAISE DE NORMALISATION. Lait et produits laitiers liquides: détermination des cendres - Norme Française V 04-208. Paris: AFNOR, 1989. 2p.

BASTIAN, E. D.; HANSEN, K. G.; BROWN, R. J. Activation of plasmin with urokinase in ultrafiltered milk for cheese manufacture. Journal of Dairy Science, v.74, p. 3669-3676, 1991.

BECH, A.-M. Characterising ripening in UF-cheese. International Dairy Journal, v.3, p.329-342, 1993.

BENTHIN, S.; VILLADSEN, J. Amino acid utilization by Lactococcus lactis subsp. cremoris FD1 during growth on yeast extract or casein peptone. Journal of Applied Bacteriology, v.80, p.65-72, 1996. 
BEUVIER, E.; BERTHAUD, K.; CEGARRA, S.; DASEN, A.; POCHET, S.; BUCHIN, S.; DUBOZ, G. Ripening and quality of Swiss-type cheese made from raw, pasteurized or microfiltered milk. International Dairy Journal, v.7, p.311-323, 1997.

BOCKELMANN, W. The proteolytic system of starter and non-starter bacteria: components and their importance for cheese ripening. International Dairy Journal, v.5, p.977-994, 1995.

BOUTON, Y.; GRAPPIN, R. Comparaison de la qualité de fromages à pâte pressée cuite fabriqués à partir de lait cru ou microfiltré. Le Lait, v.75, p.31-44, 1995.

BRADFORD, M. A rapid and sensitive method for the quantitation of microgram quantities of protein utilizing the principle of protein-dye binding. Analytical Biochemistry, v.72, p.248-254, 1976.

BRULÉ, G.; MAUBOIS, J.-L.; FAUQUANT, J. Étude de la teneur en éléments minéreaux des produits obtenus lors de l'ultrafiltration du lait sur membrane. Le Lait, v.54, p.600-615, 1974.

BRULÉ, G.; MAUBOIS, J.-L.; VANDEWEGHE, J.; FAUQUANT, J.; GOUDÉDRANCHE, $H$. Utilisation de l'ultrafiltration sur membrane pour la fabrication de fromages du type pâtes fraîches. Revue Latière Française, n.328, p.117-122, 1975.

BUIST, G.; VENEMA, G.; KOK, J. Autolysis of Lactococcus lactis is influenced by proteolysis. Journal of Bacteriology, v.180, p. 5947-5953, 1998.

CENZANO, I. Los quesos. Madrid: Mundi-Prensa Libros, 1992. cap.4, p.113-130: Los quesos de Francia.

CHAPMAN, H.R.; SHARPE, M.E. Microbiology of cheese. In: ROBINSON, R.K. (Ed.) The microbiology of milk products. London: Elsevier Applied Science, 1990. v.2, p. 203-289. 
CHAPOT-CHATIER, M.P. Les autolysines des bactéries lactiques. Le Lait, v.76, p.91-109, 1996.

CHAPOT-CHARTER, M.P.; DENIEL, C.; ROUSSEAU, M.; VASSAL, L.; GRIPON, J.C. Autolysis of two strains of Lactococcus lactis during cheese ripening. International Dairy Journal, v.4, p.251-269, 1994.

CHARVET, J.; MAUBOIS, J.-L. Microfiltration du lait de consommation, révolution dans le domaine laitier. Process, n. 1095, p.71, 1994.

CHASSY, B.M.; GIUFFRDA, A. Method for the lysis of gram-positive, asporogenous bacteria with lysozyme. Applied and Environmental Microbiology, v.39, 153$158,1980$.

CHOISY, C.; DESMAZEAUD, M.; GRIPON, J.C.; LAMBERET, G.; LENOIR, J. La biochimie de l'affinage. In: ECK, A.; GILLIS, J.-C. (Ed.). Le fromage. Paris: Technique and Documentation, 1997. cap.4, p.86-161.

CHRISTENSEN, J.E.; JONSON, M.E.; STEELE, J.L. Production of Cheddar cheese using a Lactococcus lactis subsp. cremoris SK11 derivative with enhanced aminopeptidase activity. International Dairy Journal, v.5, p.367-379, 1995.

COHEN-MAUREL, E. L'utilisation de la microfiltration tangentielle dans le traitement des liquides alimentaires. Process, n.1054, p.42-49, 1990.

COVACEVICH, H.R.; KOSIKOWSKI, F.V. Cream cheese by ultrafiltration. Journal Food Science, v.45, p.1362-1364, 1977.

COVACEVICH, H.R.; KOSIKOWSKI, F.V. Mozzarella and Cheddar cheese manufactured by ultrafiltration principles. Journal of Dairy Science, v.61, p. 701708, 1978.

COYETTE, J.; SCHOCKMAN, G.D. Some properties of the autolytic $\mathrm{N}$ acetylmuramidase of Lactobacillus acidophilus. Journal Bacteriology, v.1, p.3441, 1973. 
CREAMER, L.K. Electrophoresis of cheese: chemical methods for evaluating proteolysis in cheese maturation. Bulletin of the International Dairy Federation, n.261, p.14-28, 1991 .

CREAMER, L.K.; IYER, M.; LELIEVRE, J.L. The effects of various levels of rennet addition on characteristics of Cheddar cheese made from ultrafiltered milk. New Zealand Journal of Dairy Science and Technology, v.22, p.205-214, 1987.

CROMIE, S.J.; GILES, J.E.; DULLEY, J.R. Effect of elevated ripening temperatures of Cheddar cheese. Journal of Dairy Research, v.54, p. 69-76, 1987.

CROW, V.L.; COOLBEAR T.; HOLLAND, R.; PRITCHARD, G.G.; MARTLEY, F.G. Starters as finishers properties relevant to cheese ripening. International Dairy Journal, v.3, p.423-460, 1993.

CROW, V.L.; COOLBEAR T.; GOPAL, P.K.; MARTLEY, F.G; MC KAY L.L.; RIEP, H. The role of autolysis of lactic acid bacteria in the ripening of cheese. International Dairy Journal, v.5, p.855-875, 1995.

DE KONING, P.J.; BOER, R.; BOTH, P.; NOOY, P.F.C. Comparison of proteolysis in a low-fat semi-hard type of cheese manufactured by standard and by ultrafiltration techniques. Netherlands Milk and Dairy Journal, v.35, p.35-46, 1981.

DERRIEN, M. Caractérisation moléculaire des autolysines de Lactobacillus helveticus. Rennes, 2001. 30p. Dissertação (DEA) - École National Superieure Agronomique de Rennes, Université de Rennes I.

DUBOIS, M.; GILLES, K.A.; HAMILTON, J.K.; REBERS, P.A.; SMITH, F.; Colorimetric method for determination of sugars and related substances. Analytic Chemistry, v.28, p.350-358, 1956.

DUCRUET, P.; MAUBOIS, J.-L.; GOUDÉDRANCHE, H.; PANNETIER, R. Eléments de fabrication de fromages à pâte demi-dure et à ouverture propionique selon le procédé MMV. La Technique Laitière, n.957, p.13-16, 1981. 
EL-SHABRAWYM, S.A. Comparison of proteolysis in Edan cheese manufactured by standard and by ultrafiltration techniques. Egyptian Journal of Dairy Science, v.13, n.1, p.9-16, 1985.

EL SODA, M. Accelerated maturation of cheese. International Dairy Journal, v.3, p.531-544, 1993.

EL SODA, M. Control and enhancement of flavour in cheese. In: LAW, B.A. (Ed.) Microbiology and biochemistry of cheese and fermented milk. London: Chapman and Hall, 1997. cap.7, p.219-252.

EL SODA, M.; PANDIAN, S. Recent developments in accelerated cheese ripening. Journal of Dairy Science, v.74, p.2317-2335, 1991.

EL SODA, M.; CHEN, C.; RIESTERER, B; OLSON, N. Acceleration of low-fat cheese ripening using lyophilized extracts or freeze-shocked cells of some cheese related microorganisms. Milchwissenschaft, v.46, p.358-360, 1991.

EL SODA, M.A.; HANTIRA, A.A.; EZZAT, N.I.; EL SHAFEI, H.K. Accelerated ripening of Ras cheese using freeze-shocked mutant strains of Lactobacillus casei. Food Chemistry, v.44, p.179-184, 1992.

ENGELS, W.J.M. Volatile and non-volatile compounds in ripened cheese: their formation and their contribution to flavour. Wageningen, 1997. 127p. Thesis (Ph.D.) - Wageningen Agricultural University.

ENGELS, W.J.M.; VISSER, S. Development of cheese flavour peptides and amino acids by cell-free extracts of Lactococcus lactis subsp. cremoris B78 in a model system. Netherlands Milk and Dairy Journal, v.50, p.3-17, 1996.

ENGLER, C.R. Disruption of microbial cells. In: MOO-YOONG, M. (Ed.) Comprehensive biotechnology. Pergamon: Pergamon Press, 1985. cap. 20, p. 305-324. 
ENGLER, C.R.; ROBINSON, C.W. New method of measuring cell-wall rupture. Biotechnology and Bioengineering, v.21, p.1861-1869, 1979.

EVERSON, T. Concerns and problems of processing and manufacturing in super plants. Journal of Dairy Science, v.67, p.2095-2099, 1984.

FAUQUANT, J.; MAUBOIS, J.-L.; PIERRE, A. Microfiltration du lait sur membrene minérale. La Technique Laitière, v.1028, p.21-23, 1988.

FEDERATION INTERNATIONALE DE LAITERIE. Lait et produits laitières: denombrement des microorganismes; comptage des colonies a $30^{\circ} \mathrm{C}$ : Standard 100B: 1991. Bruxelles, 1991. 3p.

FEDERATION INTERNATIONALE DE LAITERIE. Lait et produits laitières: determination de la teneur en matière grasse: Standard 152 A: 1997. Bruxelles, 1997. 4p.

FOLLOWS, M.P.J.; HETHERINGTON, P.; DUNNILL, P.; LILLY, M.D. Release of enzymes from bakers'yeast by disruption in an industrial homogenizer. Biotechnology and Bioengineering, v.13, p.549-560, 1971.

FOX, P.F. Rennets and their action in cheese manufacture and ripening. Biotechnology and Applied Biochemistry, v. 10, p.522-535, 1988.

FOX, P.F. Proteolysis during cheese manufacture and ripening. Journal of Dairy Science, v.72, p.1379-1400, 1989.

FOX, P.F. Exogenous enzymes in dairy technology - a review. Journal of Food Biochemistry, v.17, p.173-199, 1993.

FOX, P.F.; LAW, J. Enzymology of cheese ripening. Food Biotechnology, v.5, n.3, p.239-262, 1991.

FOX, P.F.; STEPANIAK, L. Enzymes in cheese technology. International Dairy Journal, v.3, p.509-530, 1993. 
FOX, P.F.; SINGH, T.K.; McSEWEENEY, P.L.H. Proteolysis in cheese during ripening. In: ANDREWS, A.T.; VARLEY, J. (Ed.) Biochemistry of milk products. Cambridge: Royal Society of Chemistry, 1994. cap.1, p.1-31.

FRENCH, C.L.; MLNER, H.W. Disintegration of bacteria and small particles by highpressure extrusion. Methods in Enzymology, v.1, p.64-67, 1955.

FURTADO, M.M. A arte e a ciência do queijo. São Paulo: Globo, 1990. cap.5, p.115-147: Fatores que afetam as características finais do queijo.

FURTADO, M.M. Principais problemas dos queijos: causas e prevenção. São Paulo: Fonte Comunicações, 1999. cap.7, p.119-160: Problemas específicos de alguns tipos de queijos.

FURTADO, M.M.; LOURENÇO-NETO, J.P.M. Tecnologia de queijos: manual técnico para a produção industrial de queijos. São Paulo: Dipemar, 1994. 112p.

GAUTIER, M; LORTAL, S.; BOYAVAL, P; GIRARD, F.; LEMÉE, R., DE CARVALHO, A. F.; DEPUIS, C. Les bactéries propioniques laitières. Le Lait, v.73, p.257-263, 1993.

GILLOT, J.; GARCERA, D. New ceramic filter media for cross-flow microfiltration and ultrafiltration. In: FILTRA CONGRESS, 84., Paris, 1984. Proceedings. Paris: Filtra, 1984. p.2-4.

GOUDÉDRANCHE, H., FAUQUANT, J.; MAUBOIS, J.-L. Fractionation of globular milk fat by membrane microfiltration. Le Lait, v.80, p.93-98, 2000.

GOUDÉDRANCHE, H.; MAUBOIS, J.-L.; DUCRUET, P.; MAHAUT, M. Utilisation de nouvelles membranes minérales d'ultrafiltration pour la fabrication de fromages du type Saint-Paulin. La Technique Laitière, v.950, p.7-12, 1981.

GOUDÉDRANCHE, H.; DUCRUET, P.; VACHOT, J.-C.; PANNETIER, R.; MAUBOIS, J.-L. Utilization du lysozyme en tant qu'agent régulateur de l'affinage en fromagerie MMV. Le Lait, v.66, p.189-206, 1986. 
GOVINDASAMY-LUCEY, S.; GOPAL, P.K.; SUlliVAN, P.A.; PILlidGE, C. Varying influence of the autolysin, $\mathrm{N}$-acetyl muramidase, and the cell envelope proteinase on the rate of autolysis of six commercial Laciococcus lactis cheese starter bacteria grown in milk. Journal of Dairy Research, v. 67, p.585-596, 2000.

GRANDISON, A.S.; FUNIGAN, T.J.A. Microfiltration. In: GRANDISON, A.S.; LEWIS, M.J. (Ed.) Separation process in the food and biotechnology industries: principles and applications. Cambridge: Woodhead Publishing, 1996. cap.5, p.141153.

GRAPPIN, R.; RANK, T.C.; OLSON, N.F. Primary proteolysis of cheese proteins during ripening: a review. Journal of Dairy Science, v.68, n.3, p.531-540, 1985.

GRAY, P.P.; DUNNILL, P.; LILLY, M.D. The continuous-flow isolation of enzymes. In: TERUI, G. (Ed.) Fermentation technology today. Tokyo: Society for Fermentation Technology, 1972. p. 347-351.

GREEN, M.L.; GLOVER, F.A.; SCURLOCK, E.M.W.; MARSHALL, R.J.; HATFIELD, D.S. Effect of use of milk concentrated by ultrafiltration on the manufacture and ripening of Cheddar cheese. Journal of Dairy Research, v.48, p.333-341, 1981.

GRIPON, J.C.; DESMAZEAUD, M.J.; LE BARS, D.; BERGERE, J.L. Étude du rôle des microorganismes et des enzymes au cours de la maturation des fromages. II Influence de la presure commerciale. Le Lait, v.55, p.502-515, 1975.

HEMME, D.; BOUILLANNE, C.; MÉTRO, F.; DESMAZEAUD, M.-J. Microbial catabolism of amino acids during cheese ripening. Sciences des Aliments, v.2, p.113-123, 1982.

HICKEY, M.W.; VAN LEEUWEN, H.; HILLIER, A.J.; JAGO G.R. Amino acid accumulation in cheddar cheese manufacture from normal and ultrafiltered milk. The Australian Journal of Dairy Technology, n.38, p.110-113, 1983. 
HIGGINS, J.J.; LEWIS, D.J.; DALY, H.W.; MOSQUEIRA, F.G.; DUNNILL, P.; LILLY, M.D. Investigation of the unit operations involved in the continuous flow isolation of $\beta$-galoctosidase from Escherichia coli. Biotechnology and Bioengineering, v.20, p.159-182, 1978.

HUMMEL, W.; KULA, M.R. Simple method for small-scale disruption of bacteria and yeast. Journal of Microbiology Methods, v.9, p.201-209, 1989.

INTERNATIONAL DAIRY FEDERATION. Determination of the total nitrogen content of milk by Kjeldahl method: Standard 20: 1962. Brussels, 1962. 4p.

INTERNATIONAL DAIRY FEDERATION. Cheese and processed cheese: determination of the total solids content: Standard 4A: 1982. Brussels, 1982. 2p.

JAMESON, G.W.; LELIEVRE, J. Effects of whey proteins on cheese characteristics. Bulletin of the International Dairy Federation, n.313, p. 3-8, 1996.

JOHNSON, J.A.C.; ETZEL, M.R. Properties of Lactobacillus helveticus CNRZ32 attenuated by spray-drying, freeze-drying, or freezing. Journal of Dairy Science, v.78, p.761-768, 1995.

JOST, R.; JELEN, P. Cross-flow microfiltration - an extension of membrane processing of milk and whey. Bulletin of the International Dairy Federation, n.320, p.9-15, 1997.

KAMALY, K.M.; JOHNSON, M.E.; MARTH, E. H. Characteristics of Cheddar cheese made with mutant strains of lactic streptococci as adjunct source of enzymes. Milchwissenschaft, v.44, p.343-346, 1989.

KAWABATA, S.; VASSAL, L.; LE BARS, D.; CESSELIN, B.; NARDI, M.; GRIPON, J.C.; CHAPOT-CHARTIER, M.P. Phage induced lysis of Lactococcus lactis during Saint Paulin cheese ripening and its impact on proteolysis. Le Lait, v.77, p.229-239, 1997. 
KEBARY, K.M.K.; KHADER, A.E.; ZEDAN, A.N.; MAHMOUD, S.F. Accelerated ripening of low fat Ras cheese by attenuated lactobacilli cells. Food Research International, v.29, n.8, p.705-713, 1996.

KLEIN, N.; LORTAL, S. Attenuated starters: an efficient means to influence cheese ripening - a review. International Dairy Journal, v.9, p.751-762, 1999.

KLEIN, N.; MAILLARD, M.-B.; THIERRY, A.; LORTAL, S. Conversion of amino acids into aroma compounds by cell-free extracts of Lactobacillus helveticus. Journal of Applied Microbiology, v. 91, p.1-8, 2001.

KLEINIG, A.R.; MIDDELBERG, A.P.J. On the mechanism of microbial cell disruption in high-pressure homogenization. Chemical Engineering Science, v.53, p.891-898, 1998.

KOSIKOWSKI, F.V. Ultrafiltration of milk on French farms and in the making of a new specialty cheese industry. Journal of Dairy Science, v.68, p.2403-2410, 1985.

KULA, M.-R.; SCHÜTTE, H. Purifications of proteins and the disruption of microbial cells. Biotechnology Progress, v.3, p.31-42, 1987.

LAEMMLI, U.K. Cleavage of structural proteins during the assembly of the head of bacteriophage T4. Nature, v.227, p.680-685, 1970.

LANCIOTTI, R.; SINIGAGLIA, M.; ANGELINI, P.; GUERZONI, M.E. Effects of homogenization pressures on the survival and growth of some spoilage and pathogenic microorganisms. Letters in Applied Microbiology, v.18, p.319-322, 1994.

LANGSRUD, T.; LANDAAS, A.; CASTBERG, H. Autolytic properties of different strains of group N streptococci. Milchwissenschaft, v.42, p.556-560, 1987.

LAW, B.A. Proteolysis in relation to normal and accelerated cheese ripening. In: FOX, P.F. (Ed.) Cheese: chemistry, physics and microbiology. London: Elsevier Applied Science, 1987. v.1, cap.10, p.365-392. 
LAW, B.A.; GOODENOUGH, P.W. Enzymes in milk and cheese production. In: TUCKER, G.A.; WOODS, L.F.J. (Ed.). Enzymes in food processing. Glasgow: Blackie Academy \& Professional, 1995. cap. 3, p.114-143.

LAW, B.A.; WIGMORE, A.S. Accelerated ripening of Cheddar cheese with a commercial proteinase and intracellular enzymes from starter streptococci. Journal of Dairy Research, v.50, p.519-525, 1983.

LAW, B.A.; SHARPE, M.E.; REITER, B. The release of intracellular dipeptidase from starter streptococci during Cheddar cheese ripening. Journal of Dairy Research, v.41. p.137-146, 1974.

LAW, J.; HAANDRIKMAN, A. Review article: proteolytic enzymes of lactic acid bacteria. International Dairy Journal, v.7, p.1-11, 1997.

LAW, J.; FITZGERALD, G.F.; DALY, C.; FOX, P.F.; FARKYE, N.Y. Proteolysis and flavor development in Cheddar cheese made with the single starter strains Lactococcus lactis ssp. lactis UC317 or Lactococcus lactis ssp. cremoris HP. Journal of Dairy Science, v.75, p.1173-1185, 1992.

LAWRENCE, R.C. The use of ultrafiltration technology in cheesemaking. Bulletin of the International Dairy Federation, n.240, p.1-15, 1989.

LELIEVRE, J.; LAWRENCE, R.C. Manufacture of cheese from milk concentrated by ultrafiltration. Journal of Dairy Research, v.55, p.465-478, 1988.

LEMÉE, R.; LORTAL, S.; VAN HEIJENOORT, J. Autolysis of dairy propionibacteria: isolation and renaturing gel electrophoresis of the autolysins of Propionibacterium freudenreichii CNRZ 725. Le Lait, v.75, p.345-365, 1995.

LEMÉE, R.; LORTAL, S.; CESSELIN, B.; VAN HEIJENOORT, J. Involvement of an $\mathrm{N}$-Acetylglucosaminidase in autolysis of Propionibacterium freudenreichii CNRZ 725. Applied and Environmental Microbiology, v.60, p.4351-4358, 1994. 
LEMÉE, R.; ROUAULT, A.; GUEZENEC, S.; LORTAL, S. Autolysis of fifty-seven strains of dairy propionibacteria. Le Lait, v.74, p.241-251, 1994.

LEPEUPLE, A.-S.; VAN GEMERT, E.; CHAPOT-CHARTIER, M.P. Analysis of the bacteriolytic enzymes of the autolytic Lactococcus lactis subsp. cremoris strain AM2 by renaturing polyacrylamide gel electrophoresis: identification of a prophageencoded enzyme. Applied and Environmental Microbiology, v.64, p.4142-4148, 1997.

LEPEUPLE, A.S.; VASSAL, L.; CESSELIN, B.; DELACROIX-BUCHET, A.; GRIPON, J.C.; CHAPOT-CHARTIER, M.P. Involvement of a prophage in the lysis of Lactococcus lactis subsp. cremoris AM2 during cheese ripening. International Dairy Journal, v.8, p.667-674, 1998.

LORTAL, S. L'autolyse des bactéries, phénomène clé de l'affinage? Process, n.1111, p.61-62, 1995.

LORTAL, S. The bacterial autolysins and their role in cheese ripening. In: SÉMINAIRE EUROPÉEN, EFF 97., "ENZYMES FOR FOOD", Rennes, 1997. Proceedings. Rennes: CBB Developpment, 1997. p.19-20.

LORTAL, S.; BOYAVAL, P.; VAN HEIJENOORT, J. Influence de plusieurs facteurs sur l'autolyse de Lactobacillus helveticus CNRZ 414. Le Lait, v.69, p.223-231, 1989.

LORTAL, S.; LEMÉE, R.; VALENCE, F. Autolysis of thermophilic lactobacilli and dairy propionibacteria: a review. Le Lait, v.77, p.133-150, 1997.

LORTAL, S.; ROUSSEAU, M.; BOYAVAL, P.; VAN HEIJENOORT, J. Cell wall and autolytic system of Lactobacillus helveticus ATCC 12046. Journal of Genetic and Microbiology, v.137, p.549-559, 1991.

MADEC, M.N.; MEJEAN, S.; MAUBOIS, J.-L. Retention of Listeria and Salmonella cells contaminating skim milk by tangential membrane microfiltration (Bactocatch process). Le Lait, v.72, p.327-332, 1992. 
MADEC, M.N.; ROUAULT, A.; MAUBOIS, J.-L.; THIERRY, A. Milieu sélectif et procédé pour le dénombrement des bactéries propioniques. 1993. FR n 2700778 - A 1.27 jan. 1993.

MAHAUT, M.; KOROLCZUK, J.; PANNETIER, R.; MAUBOIS, J.-L. Eléments de fabrication de fromage de type pâte molle de lait chèvre à caractère lactique par ultrafiltration de lait acidifié et coagulé. Technique Laitière \& Marketing, v.1011, p.24-28, 1986.

MALIK, A.C.; REINBOLD, G.W.; VEDAMUTHU, E.R. An evaluation of the taxonomy of Propionibacterium. Canadian Journal of Microbiology, v.14, p.1185-1191, 1968.

MANNING, D.J.; MOORE, C. Headspace analysis of hard cheeses. Journal of Dairy Research, v.46, p.539-545, 1979.

MARCHISIO, M.; MORETTI, V.M.; MENTASTI, T.; VALFRÈ, F. A study of volatile compounds of milk and artisanal goat cheese. In: CONGRESS OF THE ASSOCIAZONE SCIENTIFICA DE PRODUZIONE ANIMALE, 13., Piacenza, 1999. Recent Progress in animal production science. 1: proceedings. Piacenza: Fondazione di Piacenza e Vigevano, 1999. p.525-527.

MAUBOIS, J.-L. Current uses and future perspectives of MF technology in the dairy industry. Bulletin of the International Dairy Federation, n.320, p.37-40, 1997a.

MAUBOIS, J.-L. La préparation du lait: la dégermination par microfiltration tangentielle. In: ECK, A.; GILLIS, J.-C. (Ed.). Le fromage. Paris: Technique and Documentation, 1997b. cap.4, p.257-297.

MAUBOIS, J.-L. La préparation et la mise en oeuvre des rétentats d'ultrafiltration. L'emploi du procédé MMV. In: ECK, A.; GILLIS, J.-C. (Ed.). Le fromage. Paris: Technique and Documentation, 1997c. cap.6, p.319-323.

MAUBOIS, J.-L.; KOSIKOWSKI, F.V. Making Ricotta cheese by ultrafiltration. Journal of Dairy Science, v.61, p.881-884, 1978. 
MAUBOIS, J.-L.; MOCQUOT, G.; VASSAL, L. Procédé de traitement du lait et des sous-produits laitières. 1969. $\mathrm{FR} \mathrm{n}^{\circ}$ 2052121. 18 jul. 1969.

MAUBOIS, J.-L; PIERRE, A.; FAUQUANT, J.; PIOT, M. Industrial fractionation of main whey proteins. Bulletin of the International Dairy Federation, n.212, p.154$159,1987$.

MAUBOIS, J.-L.; CAUDRON, B.; DAVIAU, C.; MADEC, M.N.; PIERRE, A. Membrane technologies: tools for a total control of the cheesemaking process. In: SYMPOSIUM OF CHEESE RIPENING AND TECHNOLOGY, Banff, 2000. Proceedings. Banff: International Dairy Federation, 2000. p.12-16.

McILLWAIN, H. Preparation of cell-free bacterial extracts with powdered alumina. Journal of General Microbiology, v.2, p.288-291, 1948.

McSWEENEY, P.L.H.; FOX, P.F. Chemical methods for the characterization of proteolysis in cheese during ripening. Le Lait, v.77, p. 41-76, 1997a.

McSWEENEY, P.L.H.; FOX, P.F. Indices of Cheddar cheese ripening. In: CHEESE SYMPOSIUM, 5., Cork, 1997. Proceedings. Cork: Moorepark, Fermoy, 1997b. p.73-89.

McSWEENEY, P.L.H.; SOUSA, M.J. Biochemical pathways for the production of flavour compounds in cheeses during ripening: A review. Le Lait, v.80, p.293-324, 2000.

McSWEENEY, P.L.H.; FOX, P.F.; LUCEY, J.A.; JORDAN, K.N.; COGAN, T.M. Contribution of the indigenous microflora to the maturation of Cheddar cheese. International Dairy Journal, v.3, p.613-634, 1993.

MEERSHON, M. Nitrate free cheese making with Bactocatch. North European and Food Dairy Journal, n. 55, p.108-113, 1989.

MERIN, U.; GORDIN, S.; TANNY, G.B. Microfiltration of sweet cheese whey. Journal of Dairy Research, v.18, p.153-160, 1983. 
MIDDELBERG, A.P.J. Process-scale disruption of microorganisms. Biotechnology Advances, v.13, p.491-551, 1995.

MISTRY, V.V.; MAUBOIS, J.-L. Application of membrane separation technology to cheese production. In: FOX, P.F. (Ed.). Cheese chemistry physics and microbiology. London: Chapman and Hall, 1993. v.1, cap.13, p.493-522.

MONDINO, A.; BONGIOVANNI, G.; FUMERO, S.; ROSSI, L. An improved method of plasma déprotéinisation with sulphosalcylic acid for determining amino acids and related compounds. Journal of Chromatography, v.74, p.255-263, 1972.

MONNET, V.; CHAPOT-CHARTIER, M.P.; GRIPON, J.C. Les peptidases des lactocoques. Le Lait, v.73, p.97-108, 1993.

MORENO, I.; LERAYER, A.L.S.; VAN DENDER, A.G.F.; LEITÃO, M.F. de F. Inibição de Listeria em queijo Minas Frescal processado com lactococos produtores de bacteriocinas. Revista de Laticínios "Cândido Tostes", v. 53, n. 304, p.238-244, 1998.

NIELSEN, P.S. Membrane filtration for fresh cultured cheese. Aarthus: APV Pasilac, 1987. 4p. (APV. Marketing Bulletin).

O’DONOVAN, C.M.; WILKINSON, M.G.; GUINEE, T.P.; FOX, P.F. An investigation of the autolytic properties of three Lactococcal strains during cheese ripening. International Dairy Journal, v.6, p.1149-1165, 1996.

OBERG, C.J.; DAVIS, L.H.; RICHARDSON, G.H.; ERNSTRON, C.A. Manufacture of Cheddar cheese using proteinase-negative mutants of Streptococcus cremoris. Journal of Dairy Science, v.69, p.2975-2981, 1986.

OMAR, M.M.; HOSAJA, M. Microstructure and chemical changes in Twarog cheese made from UF milk and from lactose hydrolyzed milk. Food Chemistry, v.22, p.147-163, 1986. 
OTTOSEN, N.; KONIGSFELD, P. Microfiltration of cheese brine. European Dairy Magazine, n.4, p.22-24, 1999.

PATEL, R.S.; REUTER, J.; PROKOPEK, D. Production of quarg by ultrafiltration. Journal of the Society of Dairy Technology, v.39, p.27-31, 1986.

PEDERSEN, P.J.; OTTOSEN, N. Manufacture of fresh cheese by ultrafiltration. Bulletin of the International Dairy Federation, n.9201, p.67-76, 1992. Special Issue.

PIERRE, A.; GOUDÉDRANCHE, H.; GAREN, A.; DAUFIN, G. Les separations sur membrane dans les procédés de l'industrie alimentaire. In: DAUFIN, G.; RENÉ, F.; AIMAR, P. (Coord.) Industrie Laitière. Paris: Technique et Documentation Lavoisier, 1998. p.282-371.

PIERRE, A.; FAUQUANT, J.; LE GRAET, Y.; PIOT, M.; MAUBOIS, J.-L. Préparation de phosphocaséinate natif par microfiltration sur membrane. Le Lait, v.72, p.461-474, 1992.

QVIST, K.B.; THOMSEN, D.; HOIER, E. Effect of ultrafiltered milk and use of different starters on the manufacture, fermentation and ripening of Havarti cheese. Journal of Dairy Research, v.54, p.437-446, 1987.

RIEPE, H.R.; PILLIDGE, C.J.; GOPAL, P.K.; MCKAY, L.L. Characterization of the highly autolytic Lactococcus lactis subsp. cremoris strains CO and 2250. Applied and Environmental Microbiology, v.63, n.10, p.3757-3763, 1997.

ROBINSON, R.K. A colour guide to cheese and fermented milks. London: Chapman and Hall, 1995. cap.7, p.129-149: Cheeses surface-ripened with a mixed microflora.

RODRÍGUEZ, J.; REQUENA, T.; FONTECHA, J.; GOUDÉDRANCHE, H.; JUÁREZ, M. Effect of different membrane separation technologies (ultrafiltration and microfiltration) on the texture and microstructure of semihard low-fat cheeses. Journal of Agriculture Food Chemistry, n.47, p.558-565, 1999. 
ROGERS H.J.; PERKINS H.R., WARD, J.B. The bacterial autolysins. In: ROGERS, H.J.; PERKINS, H.R.; WARD, J.B. (Ed.) Microbial cell walls and membranes. London: Chapman and Hall, 1980. p.437-460.

SABLE, S.; LORTAL, S. The lysins of bacteriophages infecting lactic acid bacteria. Applied Microbiology Biotechnology, v.43, p.1-6, 1995.

SABOYA, L.V.; MAUBOIS, J.-L. Current developments of microfiltration technology in the dairy industry. Le Lait, v.80, p.541-553, 2000.

SABOYA, L.V.; MAILLARD, M.-B.; LORTAL, S. Efficient and easy mechanical disruption of Lactobacillus helveticus, Lactococcus lactis and Propionibacterium freudenreichii by a new pilot high-pressure homogenizer. 2002. /no prelo/

SABOYA, L.V.; OLIVEIRA, A. J.; FURTADO, M.M.; SPADOTI, L.M. Efeitos fisicoquímicos da adição de leite reconstituído na fabricação de queijo Minas Frescal. Ciencia e Tecnologia de Alimentos, v.18, p.368-376, 1998.

SABOYA, L.V.; GOUDEDRANCHE, H.; MAUBOIS, J.-L.; LERAYER, A.L.S.; LORTAL, S. Impact of broken cells of lactococci or propionibacteria on the ripening of Saint-Paulin UF-cheeses: extent of proteolysis and GC-MS profiles. Le Lait, v.81, p.699-713, 2001.

SALTON, M.R.J.; HORNE, R.W. Studies of the bacterial cell wall. II. Methods of preparation and some properties of cell walls. Biochimica and Biophysica Acta v.7, p.177-197, 1951.

SANDBLOM, R.M. Filtering process. 1974. SW n`7416257. 23 dec. 1974.

SAUDAN, M.; ZITT, M.; ARNOUX, L.; BRION, M. Le procedé MMV: étude économique - rapport de synthèse. Paris: ANVAR, 1975. 12p.

SHALABI, S.I.; FOX, P.F. Electophoretic analysis of cheese: comparison of methods. Irish Journal of Food Science and Technology, v.11, n.2, p.135-151, 1987. 
SHOCKMAN, G.D.; HÖLTJE, J.V. Microbial peptidoglycan (murein) hydrolases: comprehensive biochemistry. In: GHUYSEN, J.M.; HAKENBECK, R. (Ed.) Bacterial cell wall. Amsterdam: Elsevier Sciences, 1994. cap 7, p.131-166.

SIEGEL, J.L., HURST, S.F., LIBERMAN, E.S., COLEMAN, S.E.; BLEIWEIS, A.S. Mutanolysin-induced spheroplasts of Streptococcus mutans are true protoplasts. Infection and Immunity, v.31, p.808-815, 1981.

SPACKMAN, D.H.; STEIN, W.H.; MOORE, S. Automatic recording apparatus for use in chromatography of amino acids. Analytic Chemistry, v.30, p.1190-1206, 1958.

SPANGLER, P.L.; EL SODA, M.; JOHNSON, M.E.; OLSON, N.F.; AMUNDSON, C.H.; HILL JR., C.G. Accelerated ripening of Gouda cheese made from ultrafiltered milk using a liposome entrapped enzyme and freeze shocked lactobacilli. Milchwissenschaft, v.44, p.189-203, 1989.

STEFFEN, C.; EBERHARD, P.; BOSSET, J.O.; RÜEGG, M. Swiss type varieties. In: FOX, P.F. (Ed.) Cheese: chemistry, physics, and microbiology. London: Chapman and Hall, 1993. cap.3, p. 83-110.

STRANGE, E.D.; MALIN, E.L.; VAN HEKEN, D.L.; BASCH, J.J. Chromatographic and electrophoresis methods used for analysis of milk proteins. Journal of Chromatography, v.624, p.81-102, 1992.

TAN, P.S.T.; CHAPOT-CHARTIER, M.P.; POS, K.M.; ROUSSEAU, M.; BOQUIEN, C.Y.; GRIPON, J.C.; KONINGS, W.N. Localization of peptidases in lactococci. Applied Environmental Microbiology, v.58, p.285-290, 1992.

TERZAGHI, B.E.; SANDINE, W.E. Improved medium for lactic streptococci and their bacteriophages. Applied Microbiology, v.29, p.807-813, 1975.

THIERRY, A.; MAILLARD, M.-B. Production of cheese flavour compounds derived from amino acid catabolism by Propionibacterium freudenreichii: A review. Le Lait, v. 81, p. 17-32, 2002. 
THIERRY, A.; MAILLARD, M.-B.; LE QUÉRÉ, J.-L. Dynamic headspace analysis of Emmental aqueous phase as a method to quantify changes in volatile flavour compounds during ripening. International Dairy Journal, v.9, p.453-463, 1999.

THIERRY, A.; MAILLARD, M.-B.; YVON, M. Conversion of L-Leucine to isovaleric acid by Propionibacterium freudenreichii TL 34 and ITGP23. Applied and Environmental Microbiology, v.62, 2002. / no prelo/

TROUVÉ, E.; MAUBOIS, J.-L.; PIOT, M.; MADEC, M.N.; FAUQUANT, J.; ROUAULT, A.; TABARD, J.; BRINKMAN, G. Rétention de différentes espèces microbiennes lors de l'épuration du lait par microfiltration en flux tangentiel. Le Lait, v.71, p.1-13, 1991.

UNEMOTO, Y.; SATO, Y.; KITO, J. Direct observation of fine structures of bacteria in ripened Cheddar cheese by electron microscopy. Agricultural and Biological Chemistry, v.42, p. 227-232, 1978.

VALENCE, F. Mise au point de marqueurs immunologiques spécifiques pour suivre l'autolyse des levains dans les produits laitières: programme financé par BBA et la région Bretagne. Rennes: Institut National de la Recherche Agronomique, Laboratoire de Recherches de Technologie Laitière, 1999. 27p.

VALENCE, F.; LORTAL, S. Zymogram and preliminary characterization of Lactobacillus helveticus autolysins. Applied and Environmental Microbiology, v.61, p.3391-3399, 1995.

VALENCE, F.; DEUTSCH, S.M.; RICHOUX, R.; GAGNAIRE, V.; LORTAL, S. Autolysis and related proteolysis in Swiss cheese for two Lactobacillus helveticus strains. Journal of Dairy Research, v.67, p.261-271, 2000.

VALENCE, F.; RICHOUX, R.; THIERRY, A.; PALVA, A.; LORTAL, S. Autolysis of Lactobacillus helveticus and Propionibacterium freudenreichii in Swiss cheeses: first evidence by using species-specific lysis markers. Journal of Dairy Research, v.65, p. 609-620, 1998. 
VAN DENDER, A.G.F.; MASSAGUER-ROIG, S.; CAMPOS, S.D.S. Alterações físico-químicas e vida-de-prateleira do queijo "Minas Frescal" tradicional e fabricado pelo método MMV. In: CONGRESSO NACIONAL DE LATICÍNIOS, 16., Juiz de Fora, 1999. Anais. Revista do Instituto de Laticínios "Cândido Tostes". v.54, n.309, p.67-82, 1999.

VEGARUD, G.; CASTBERG, H.B.; LANGSRUD, T. Autolysis of group N streptococci. Effects of media composition modifications and temperature. Journal Dairy Science, v.66, p.2294-2302, 1983.

VEINOGLOU, B.C.; BOYAZOGLU, E.S. Improvement in the quality of Teleme cheese produced from ultrafiltered cow's milk. Journal of the Society of Dairy Technology, v.35, p.54-56, 1982.

VIEIRA, S.D.A.; GOUDÉDRANCHE, H.; DUCRUET, P.; MAUBOIS, J.-L. Eléments de fabrication d'un nouveau fromage brésilien de type "Minas Frescal" par le procédé M.M.V. Technique Laitière, n.978, p.17-20, 1983.

VINCENT, C. Proteínes: électrophorèse et électrofocalisation. Biofutur, n.54, p.3-13, 1987.

VISSER, S. Proteolytic enzymes and their relation to cheese ripening and flavour: an overview. Journal of Dairy Science, v.76, p.329-350, 1993.

WAGNER, J.; RUBIN, J. Ultrafiltration of milk for production of Feta cheese and hydrolysis of lactose by enzymes. In: INTERNATIONAL CONGRESS ON ENGINEERING AND FOOD, 2., Helsinki, 1979. Proceedings. Helsinki: Pasilac, 1979. p.27-31.

WALLACE, J.M.; FOX, P.F. Effect of adding free amino acids to Cheddar cheese curd on proteolysis, flavour and texture development. International of Dairy Journal, v.7, p.157-167, 1997.

WALSTRA, P. On the stability of casein micelles. Journal of Dairy Science, v.73, p.1965-1979, 1990. 
WILKINSON, M.G. Acceleration of cheese ripening. In: FOX, P.F. (Ed.) Cheese chemistry physics and microbiology: general aspects. London: Chapman and Hall, 1993. cap. 14, p.523-555.

WILKINSON, M.G.; GUINEE, T.P.; O’CALLAGHAN, D.M.; FOX, P.F. Autolysis and proteolysis in different strains of starter bacteria during Cheddar cheese ripening. Journal of Dairy Research, v.61, p.249-262, 1994.

WILKINSON, M.G.; GUINEE, T.P.; O'CALLAGHAN, D.M.; FOX, P.F. Effect of cooking temperature on the autolysis of starter, Lactococcus lactis subsp. cremoris AM2, and the maturation of Cheddar cheese. Milchwissenschaft, v.50, p.376-380, 1995.

WOLFSCHOON-POMBO, A. L. Índice de proteólise em alguns queijos brasileiros. Boletim do Leite e seus Derivados, v.56, p.1-8, nov. 1983.

WOLFSCHOON-POMBO, A. L.; LIMA, A. Extensão e profundidade da proteólise em queijo Minas Frescal. Revista do Instituto de Laticínios "Cândido Tostes", v.44, p.50-54, 1989.

WOLFSCHOON-POMBO, A.F.; FURTADO, M.M.; MUNCK, A.V. Estudo da fabricação do queijo Minas Frescal com ácido lático em substituição ao fermento lático. In: CONGRESSO NACIONAL DE LATICÍNIOS, 5., Juiz de Fora, 1978. Anais. Juiz de Fora: EPAMIG, 1978. p.161-182.

WOLFSCHOON-POMBO, A.F.; CASAGRANDE, H.R.; LORENÇO-NETO, J.P.M.; MUNCK, A.V. Alterações no queijo Minas Frescal durante o período de armazenamento. Revista do Instituto de Laticínios “Cândido Tostes”, v.39, p.3$9,1984$.

YOKOGAWA, K.; KAWATA, T.; TAKESMURA, T.; YOSHIMURA, Y. Purification and properties of lytic enzymes from Streptomyces globisporus 1829. Agricultural and Biological Chemistry, v.39, p.1533-1543, 1975. 
YVON, M., RIJNEN, L. Cheese flavour formation by amino acid catabolism. International Dairy Journal, v. 11, n.4/7, p.185-201, 2001.

YVON, M.; THIROUIN, S.; RIJNEN, L.; FROMENTIER, D.; GRIPON, J.C. An aminotransferase from Lactococcus lactis initiates conversion of amino acids to cheese flavor compounds. Applied and Environmental Microbiology, v.63, p.414-419, 1997. 


\section{APÊNDICE 1}

"Current developments of microfiltration technology in the dairy industry"

SABOYA, L.V.; MAUBOIS, J.-L.

Artigo publicado na Revista: Le Lait, v.80, p.541-553, 2000. 


\title{
Current developments of microfiltration technology in the dairy industry
}

\author{
Luciana V. SABOYA ${ }^{\mathrm{a}}$, Jean-Louis MAUBOIS ${ }^{\mathrm{b} *}$ \\ a Escola Superior de Agricultura "Luiz de Queiroz" (ESALQ - USP), \\ Av. Pádua Dias 11, 13418-900/Piracicaba, SP, Brasil \\ ${ }^{b}$ Laboratoire de Recherches de Technologie Laitière, INRA, \\ 65 rue de Saint Brieuc, 35042 Rennes Cedex, France
}

(Received 2 May 2000; accepted 27 September 2000)

\begin{abstract}
This paper deals with the most recent developments of cross flow microfiltration (CFMF), some of them just patented, in the dairy industry. Combination of the use of uniform transmembrane hydraulic pressure concept (UTP) with its different ways of carrying out microfiltrate recirculation, longitudinal porosity gradient and of new ceramic membrane materials allows nowadays to get a differential separation of each category of milk particles. Pretreatment by CFMF of incoming milk is used for the production of low heated fluid milks having a flavor similar to that of raw milk and a shelf life 3 to 5 times longer than that of classical products. Results observed in the retention by the MF membrane of pathogenic bacterial species allow it to be said that the hygienic safety of cheeses made from raw MF milk is, at least, equal or even higher than that of cheeses made from pasteurized milk. Numerous other applications of CFMF are under development such as removal of residual fat from whey or the clarification and the removal of bacteria from cheese brine but the most promising are undoubtedly the differential separation of micellar casein and of small milk fat globules. With the products obtained on both sides of the MF membrane, dairy technology will have the possibility not only to improve yield and quality of many dairy products but also to create a diversified range of new textures.
\end{abstract}

microfiltration / membrane / liquid milk / native casein / brine / whey / cheese

Résumé — Développements actuels de la technologie de microfiltration dans l'industrie laitière. Cet article traite des développements les plus récents, certains tout juste brevetés, de la microfiltration tangentielle dans l'industrie laitière. La combinaison de l'utilisation du concept de pression transmembranaire uniforme, avec ses différentes possibilités de mise en œuvre : recirculation du microfiltrat, gradient de porosité longitudinal, et de nouveaux matériaux membranaires céramiques

* Correspondence and reprints

Tel.: (33) 2234853 22; fax: (33) 2234853 50; e-mail: maubois@ labtechno.roazhon.inra.fr 
permet maintenant d'obtenir une séparation différentielle de chaque catégorie de particule laitière. Le prétraitement par microfiltration tangentielle du lait est utilisé pour la production de lait de consommation peu chauffé ayant une flaveur similaire à celle du lait cru et une durée de vie 3 à 5 fois supérieure à celle des produits classiques. Les résultats observés sur la rétention par les membranes de microfiltration d'espèces bactériennes pathogènes permet de dire que la sécurité hygiénique des fromages fabriqués à partir de lait cru microfiltré est au moins équivalente et même supérieure à celle des fromages fabriqués à partir de lait pasteurisé. Plusieurs autres applications de la microfiltration tangentielle sont en cours de développement, comme l'extraction de la matière grasse résiduelle du lactosérum ou la clarification et la séparation des bactéries des saumures de fromage, mais la plus prometteuse est indubitablement la séparation différentielle de la caséine micellaire et des petits globules gras du lait. Avec les produits obtenus des deux côtés de la membrane de microfiltration, la technologie laitière aura la possibilité non seulement d'améliorer le rendement et la qualité de beaucoup de produits laitiers mais aussi de créer une gamme diversifiée de nouvelles textures.

microfiltration / membrane / lait de consommation / caséine native / saumure / lactosérum / fromage

\section{INTRODUCTION}

Microfiltration (MF) like all the other membrane separation processes is a technique which allows the differential concentration in the liquid retained by the membrane, named MF retentate, of the components with a size bigger than the average pore diameter of the membrane. The liquid going through the MF membrane is named microfiltrate. It contains, at the same concentration as those existing in the incoming treated liquid, the components with a size smaller than the average pore diameter.

As shown in Figure 1, pore diameter of MF membranes ranges from $10 \mu \mathrm{m}$ to $0.1 \mu \mathrm{m}$, which means MF will be used for the specific separation of the particles suspended in liquids.

Milk contains particles of which the size distribution ranges (Tab. I) are relatively well separated. By decreasing size, they are somatic cells $(15-6 \mu \mathrm{m})$, fat globules $(15-0.2 \mu \mathrm{m})$, bacteria $(6-0.2 \mu \mathrm{m})$ and casein micelles $(0.3-0.03 \mu \mathrm{m})$ [40].

The breakthrough of MF in the dairy industry came in the 1980 s with the development of new ceramic membranes comprising a multichannel geometry and a highly permeable support [15] which made industrially feasible the revolutionary hydraulic concept proposed by Sandblom [47]: the uniform and low transmembrane pressure (UTP). The UTP concept overcomes most of the heterogeneous fouling of the MF membrane which results from the high cross flow velocities required for obtaining both high permeation fluxes and accurate selectivity.

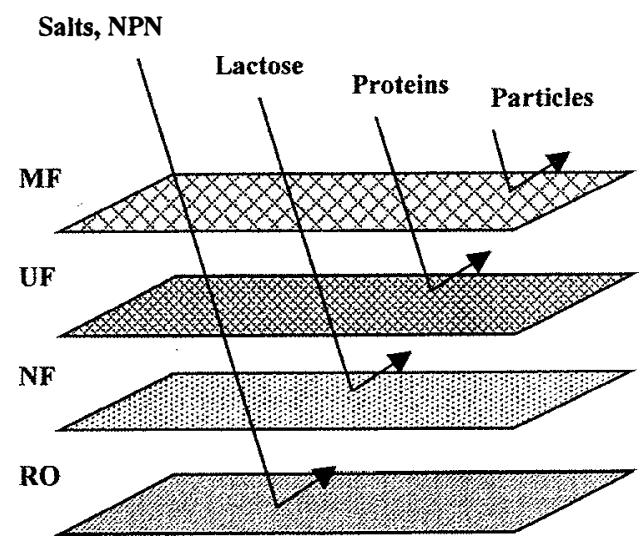

Figure 1. Illustration of filtration membranes: microfiltration (MF), ultrafiltration (UF), nanofiltration (NF), reverse osmosis (RO).

Figure 1. Illustration de la filtration membranaire : microfiltration (MF), ultrafiltration (UF), nanofiltration (NF), osmose inverse (OI). 
Table I. Relative diameters of milk particles (adapted from [40]).

Tableau I. Diamètre moyen des particules du lait (adopté de [40]).

\begin{tabular}{lr}
\hline Component & \multicolumn{1}{c}{ Size $(\mu \mathrm{m})$} \\
\hline Casein micelles & $0.300-0.032$ \\
Bacteria & $15.000-0.200$ \\
Fat globules & $6.000-0.200$ \\
Somatic cells & $15.000-6.000$
\end{tabular}

Cross flow microfiltration (CFMF) has emerged as an industrial separation technology in the dairy industry for at least three main applications: (i) removal of bacteria [25, 50], (ii) whey defatting [39], and (iii) micellar casein enrichment of the cheesemaking [9], but numerous other applications are currently being investigated, such as selective separation of somatic cells from raw whole milk, whey or milk protein fractionation or milk fat separation.

\section{MICROFILTRATION ENGINEERING CONSIDERATIONS}

Efficiency of any membrane separation technologies is governed by many parameters: amongst them the most active are the materials constituting the membrane and its support and the hydrodynamics of the whole equipment.

\subsection{Membranes}

In the early 80 s, attempts were made to use MF as an alternative technology to centrifugation for clarification and microbial epuration of whey $[32,33,41]$ but the available organic membrane materials (polysulfone and polycarbonate) were not satisfactory both in terms of flux and selectivity as well as in terms of mechanical heat and chemical stability [20]. A novel opportunity was offered for the envisaged applications in the dairy industry by the commercial emergence of the ceramic-based membranes [14] originally developed for isotope enrichment in the nuclear industry. Nevertheless, if the chemical and heat stability of this new membrane generation was corresponding fully to requirements of the dairy industry, flux decline and changes in selectivity versus time were so high [42] that none of the proposed processes $[16,42]$ could be considered as suitable for industrial scale-up. Most of the encountered problems in controlling the fouling of MF membranes over time by the deposited milk components were solved by the carrying out of the hydraulic concept of the uniform transmembrane pressure (UTP) proposed as early as 1974 by Sandblom [47]. The different membrane and system configurations currently used for obtaining hydraulic UTP are described later.

Pore sizes of MF ceramic membranes range from $20 \mu \mathrm{m}$ to $0.1 \mu \mathrm{m}$. Structures and methods of manufacture of these membranes are described by Rios et al. [44]. In a first approach, membranes consist of two parts: a macroporous support and the active membrane coated onto the surface. The supporting materials made from alumina (the most developed), carbon, stainless steel or $\mathrm{SiC}$ (not employed in the food industry because of its low stability at high $\mathrm{pH}$ ) must drain away the permeate without any hydrodynamic resistance and thus have a minimum pore diameter of $10 \mu \mathrm{m}$. The membrane layer (usually composed of alumina, titanium oxide or zirconia or a mixture of both oxides) is formed by coating the support with a colloidal suspension of highly divided powder (more than $100 \mathrm{~m}^{2} \cdot \mathrm{g}^{-1}$ ), then sintered to the support by firing. Membrane thickness is around to 3-5 $\mu \mathrm{m}$ [18]. Narrow pore size distribution is obtained through both accurate control of the colloidal particle size and sintering of two, or sometimes three successive layers (Société des Céramiques Techniques - SCT, personal communication). 
Such a restriction of the width of the Gaussian distribution curve of the pore diameter can improve significantly the selectivity of the MF process. For example, substitution of a $1.4 \mu \mathrm{m}$ pore size Membralox by a $1.4 \mu \mathrm{m}$ Sterilox i.e. with the same average pore diameter but with a much narrower pore size distribution increases the MF retention of milk bacteria by $2 \log [26]$. As said before, ceramic membranes are the only ones that satisfy all the requirements of the applications in the dairy industry i.e. a strong mechanical resistance which allows the use of high recirculation velocities of viscous MF retentates, a wide tolerance to $\mathrm{pH}(0.5$ to 13.5) allowing its usage for cleaning in place of caustic soda (up to 3\%), of nitric acid (up to $2 \%$ ) - but phosphoric and hydrofluoric acids should be avoided - and of sodium hypochlorite for sanitation. Membranes were configured originally in monotubes with an inner diameter ranging from 3 to $8 \mathrm{~mm}$ and a length around $85 \mathrm{~cm}$. Recent designs concem mostly the multichannel configuration with either classical cylindrical channels or various cross section forms: square, trifolium or "daisy" like those proposed by the Tami ${ }^{\circledR}$ Co. Monotubular and multichannel monoliths, whose the length is now more than $1 \mathrm{~m}$ are assembled in bundles placed in stainless steel housings named MF modules. The area developed in one module ranges from $0.2 \mathrm{~m}^{2}$ to $10 \mathrm{~m}^{2}$ or more according to the manufacturer. Most of the proposed modules are steam sterilizable but in practice, the operating temperatures are limited not by the membranes, which can withstand temperatures of several hundred ${ }^{\circ} \mathrm{C}$, but by the other components of the MF module such as gaskets.

\subsection{MF equipment configurations}

Except for some old equipment for whey defatting, the first industrial application of MF in the dairy industry $[8,29]$, most of the current MF plants operate according to the hydraulic concept of UTP. To overcome the rapid fouling of the MF membrane resulting from the necessary high cross-flow velocity conditions of the MF retentate (more than $7 \mathrm{~m} \cdot \mathrm{s}^{-1}$ ), Sandblom [47] has suggested recirculating the MF permeate, in such flow conditions that the transmembrane pressure is low and uniform all along the membrane (Fig. 2). In the method patented by Alfa Laval [19], the permeate compartment filled with plastic balls is pressurized by pumping the permeate in a loop parallel to the direction of the retentate flow. A basic MF system comprises a feed tank, a feed pump and two recirculation loops: one for the MF retentate including one or a multiple number of two modules and a heat exchanger - one for the MF permeate. Both loops have outlet valves regulated by sensors for a continuous production of the two separated fluids.

Recent developments in ceramic membrane technology have allowed the suppression of the MF permeate recirculation loop, and thus a decrease in the investment cost per $\mathrm{m}^{2}$ of installed equipment and a saving of some consumed energy. The first one, known as Membralox $\mathrm{GP}^{\circledR}$, was developed by SCT [10]. The requested counterpressure in the permeate side is obtained by a continuous variation of the porosity of the membrane ceramic support. The second one very recently proposed by Tami Co, named "Isoflux ${ }^{\circledR 3 ", ~ c l a i m s ~ o b t a i n i n g ~ U T P ~ b y ~ a ~ c o n-~}$ tinuous gradient of MF membrane thickness. Both developments must be used for welldefined applications, the porosity gradient of the membrane support as well as the thickness gradient of the membrane being both built for precise flux and selectivity.

\subsection{Starting procedure}

MF equipment must be started with care in order to avoid dramatic and fast fouling. They are firstly filled with warm water $\left(52^{\circ} \mathrm{C}\right)$ with the air exhaust valve open for removing air bubbles. Then, hydraulic recirculation parameters which will be used on 


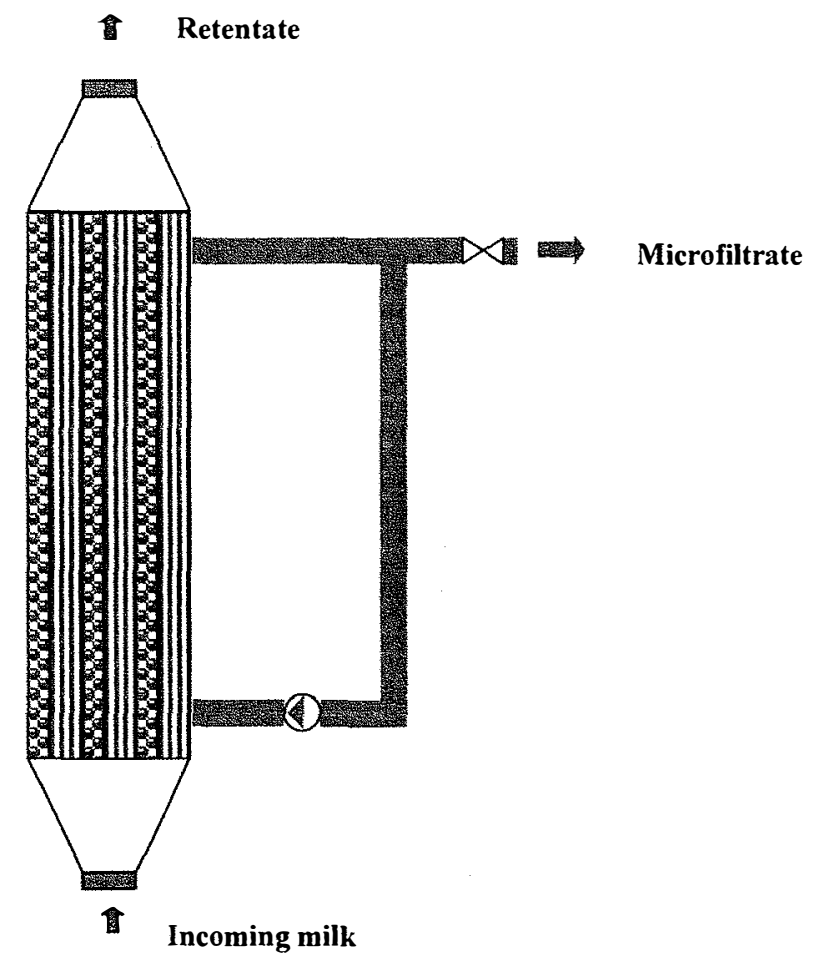

Pressure profiles

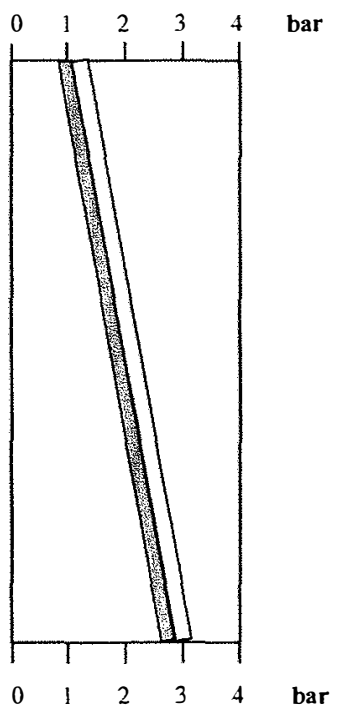

Figure 2. Pressure profiles during cross flow microfiltration.

Figure 2. Profil des pressions en microfiltration tangentielle.

milk are adjusted on the recirculated water. Finally, milk of which the physico-chemical equilibrium has been reestablished i.e. by a preheating of $50{ }^{\circ} \mathrm{C}$ for $20 \mathrm{~min}$, is progressively introduced in the MF retentate loop. The hydraulic parameters are readjusted during the first ten minutes before running in stationary conditions.

\subsection{Cleaning and sanitation of the MF equipment}

Cleaning of MF equipment is performed in the same way as for all membrane technologies with differences coming from the nature of the membrane material and from a demand for a higher degree of water quality. Indeed, water utilized for the rinsing steps as well as for the preparation of the different solutions must not contain suspended colloidal particles or microorganisms susceptible to cause an inside blocking of the membrane pores or an undesirable bacterial contamination of the cleaned equipment. Consequently, dwell and tap water must be not only softened but also microfiltrated on a $0.2 \mu \mathrm{m}$ dead end filter before being used for cleaning.

The cleaning cycle used includes:

- rinse with water heated at $50{ }^{\circ} \mathrm{C}$;

- alkaline cleaning with a ternary detergent such as Ultrasil ${ }^{\circledR} 25$ (Henkel) at a concentration of $0.5-1.0 \%$ or similar product at $65-70{ }^{\circ} \mathrm{C}$ for $20 \mathrm{~min}$ in the same operating conditions as the ones used for the applications;

- rinse with water at $50{ }^{\circ} \mathrm{C}$;

- facultatively sanitation with $\mathrm{ClONa}$ $200 \mathrm{ppm}$ at $20^{\circ} \mathrm{C}$ for $15 \mathrm{~min}$; 
- acid cleaning $\mathrm{NO}_{3} \mathrm{H} 0.5 \%$ for $20 \mathrm{~min}$ at $50{ }^{\circ} \mathrm{C}$ in the same operating conditions as those used for the alkaline step;

- rinse with water at $50{ }^{\circ} \mathrm{C}$.

Efficiency of the cleaning is checked by the water flux in defined conditions and by the bacteriological quality of the last rinse (no CFU in $100 \mathrm{~mL}$ ).

\section{APPLICATIONS OF MF IN THE DAIRY INDUSTRY}

The major application of MF in the dairy industry concems the removal of microorganisms from skim milk in order to produce a debacterized raw material which is afterwards transformed into fluid milks, cheeses or long storage dairy products such as powder or protein derivatives. Another emerging application is the selective separation of micellar casein, which opens new avenues for better added values of milk components. Moreover these two main industrial developments, numerous other applications have been proposed which will be briefly reviewed here.

\subsection{Bacterial removal}

\subsubsection{Current development for the fluid milk industry}

Milk collected by the dairy plant always contains a microbial flora formed by numerous species illustrating the contaminations of milk by the udder, the milking machine, the local farm atmosphere, the bulk tank and the transportation equipment. Taking into consideration all these potential contaminations, one can say that whatever are or whatever will be the hygienic practices at farm level, the collected milk will be always contaminated. Cow husbandry cannot be done in aseptic conditions and milk will always have the risk of containing pathogenic bacteria for human beings such as Listeria, Brucella, Mycobacterium or Salmonella.
Destruction of the potentially risky flora has been done for fifty years by applying to milk heat treatments such as HTST pasteurization or UHT. But if heating effectively kills most of the microbial flora, the dead cells remain in the milk with their potentially active enzymes that with the metabolic activity developed by the growth of the remaining thermoduric bacteria, will cause alterations of liquid milks during storage, thus reducing shelf-life.

Membrane MF offers an interesting alternative to heat treatments. Initially proposed by Holm et al. [19] and Piot et al. [42], it has led to the technology and the equipment called "Bactocatch ${ }^{\circledR, "}$ by the Tetra Laval Co. Numerous studies done in Sweden [25, 31] and in France [24, 26, 50, 51] have allowed improvements of the original parameters described in the patent of Holm et al. [19]. Nowadays, skim milk heated to $50^{\circ} \mathrm{C}$ is circulated at a velocity of $7.2 \mathrm{~m} \cdot \mathrm{s}^{-1}$ along a Sterilox ${ }^{\circledR}$ membrane with an average pore size of $1.4 \mu \mathrm{m}$. The value of the uniform transmembrane pressure (UTP) is around 0.5 bar. The volumetric reduction factor (VRF) is 20 and in some huge equipment, the $5 \%$ flow represented by the MF retentate is concentrated 10 times more in cascade by a second MF apparatus, thus leading to a VRF of 200. Permeation rates of proteins and total solids are respectively higher than $99.0 \%$ and $99.5 \%$. Fluxes obtained industrially are in the order of $500 \mathrm{~L} \cdot \mathrm{h}^{-1} \cdot \mathrm{m}^{-2}$ during $10 \mathrm{~h}$.

Average observed decimal reduction (DR) is above 3.5 which means for an entering $20000 \mathrm{CFU} \cdot \mathrm{mL}^{-1}$ skim milk, the microfiltrated product contains less than $10 \mathrm{CFU} \cdot \mathrm{mL}^{-1}$. Spore forming bacteria which represent the main surviving species to pasteurization are better retained by MF membrane because of their large cellular volume as shown by Trouvé et al. [50]. The observed DR are higher than 4.5.

Synthesis of the studies done by Madec et al. [24], Pasteur Institute and INRA (data not published) shows for Listeria monocytogenes, Brucella abortus, Salmonella 
typhimurium and Mycobacterium tuberculosis respective DR of 3.4, 4.0, 3.5 and 3.7. Such results will assure that MF skim milk will contain less than $1 \mathrm{CFU} \cdot \mathrm{L}^{-1}$ of these pathogenic bacteria if we take into account usually described contaminations at farm level.

Somatic cells are evidently totally retained by the MF membrane and consequently MF milk will not be degraded by their thermoduric enzymes [22].

Several varieties of MF liquid milks are presently offered to the consumers. In France, the Marguerite ${ }^{\circledR}$ milk is considered to be a raw milk because no pasteurization is applied. The MF skim milk is mixed with the amount of heated cream $\left(95^{\circ} \mathrm{C}, 20 \mathrm{~s}\right)$ requested for fat standardization; the mixture is slightly homogenized and aseptically filled. The claimed shelf life at $4-6{ }^{\circ} \mathrm{C}$ is 15 days. In Scandinavia, Canada [7] and the UK [45], before aseptic filling a HTST $\left(72{ }^{\circ} \mathrm{C}, 15 \mathrm{~s}\right)$ heat treatment is applied, leading to a claimed shelf life of 35 days. These MF milks encounter great commercial success because of their flavor (no cooked taste) and their improved storage ability [7].

APV has patented a variant of the Bactocatch process which proposed the mixing of highly heat-treated MF retentate with cream and MF milk. Such a mixing is never done nowadays by the Bactocatch users. In the APV variant, the MF retentate, not heattreated, is retumed to the raw milk entering the cream separator. Consequently, most of the bacteria as well as somatic cells are discharged through the separator sludge [34].

Use of smaller pore diameter $(0.5 \mu \mathrm{m}$ effective) recently proposed by Lindquist [23] has shown a bacteria removal increased by 2 or even $3 \log$ cycles compared to the $1.4 \mu \mathrm{m}$ pore diameter. Membranes utilized in this patent were either Membralox ${ }^{\circledR}$ or Pall ${ }^{\circledR}$ ones set respectively in a classical cross flow equipment and in a Dynamic Membrane Filtration equipment. Decrease of pore size evidently leads to a slight decrease of casein micelles permeation rate but the bacterial epuration of the skim milk is so high (remaining count is less than $1 \mathrm{CFU} \cdot \mathrm{L}^{-1}$ ) that to obtain a fluid milk with a long shelf life at room temperature, a moderate heat treatment (less than $100^{\circ} \mathrm{C}, 2 \mathrm{~s}$ ) is necessary. This new fluid milk is under commercial development and the first results (Fauquant, Madec and Maubois, data nonpublished) indicate a room temperature shelf life ranging from 6 to 9 months. Sensory tests show a flavor close to the one of HTST classical milks and much better than the current UHT milks.

As well as the use for the fluid milk sector, MF pretreatment of the skim milk can be expanded to all skim milk used for the production of milk derivatives such as low-heat milk powder as proposed by Schuck et al. [48], milk proteins concentrates or micellar casein powder [49]. On the other hand, MF milks, because of the removal of dead cells and somatic cells, offer to the dairy scientist the chance to study without any bias the exact effect of endogenous enzymes on milk components.

\subsubsection{Current developments for the cheese industry}

Cheese consumers wish to have the possibility to buy and to eat both cheeses with typical flavor and texture, characteristic of a geographical area i.e. cheeses belonging to their cultural patrimony, as well as more classical cheeses for daily consumption. As well as this diversified offer, the consumers also want a constant high quality and no hygienic risk. Such high requirements call for a complete control of the cheesemaking process starting from the raw material collected by the cheese plant.

Use of milks pretreated by MF with the same technology as described before for the fluid milk production i.e. a mixture of MF skim milk and heat-treated cream but sometimes with the variant of a lower MF temperature $\left(35-37{ }^{\circ} \mathrm{C}\right)$ in order to respect the raw milk labeling, offer to the cheese 
technologist a complete control of the raw material. Consequently, it can be claimed that cheeses made from MF milk are at least as safe from a hygienic point of view than cheeses made from pasteurized cheese milk. Moreover, because MF membrane removes, at a very high level, spore-forming bacteria such as Clostridium tyrobutyricum $[31,50]$, addition of nitrate at a level of $15 \mathrm{~g}$ per $100 \mathrm{~kg}$ as it is done in a few countries such as The Netherlands to prevent late blowing in semi hard or hard cheeses, could be suppressed with the positive consequences for environment and consumer health.

On the other hand, use of MF milk opens for the cheese scientist new ways to determine and to characterize the exact role played in cheese ripening by each microbial species or strain composing the ripening ecosystem, i.e., lactic acid bacteria, nonstarter lactic acid bacteria, propionibacteria, surface yeasts and molds [30], without the bias always introduced in the published studies by the use of heat sterilized milks, i.e., milks with the enzymatic potential of dead cells.

But, as described by Maubois et al. [30] use of MF milk in cheesemaking brings up numerous scientific and legal questions, particularly for AOP cheeses:

- Are they still raw milk cheeses? With current technology, removal of bacteria is done by $\mathrm{MF}$ at $35^{\circ} \mathrm{C}$ on about $90 \%$ of the cheese milk. The cream part is highly heattreated (generally $90-95^{\circ} \mathrm{C}, 2$ or $3 \mathrm{~min}$ ). What are the effects of this heating on fat, on the globule membranes? What are the consequences on the casein network structure during formation and ripening by comparison with the use of a totally non-heated cheesemilk?

- Many studies demonstrate that natural flora plays a major role in the development of flavor and texture characteristics of AOP cheeses. Separation and concentration of this natural flora by MF is easy and as very well shown by Demarigny [6], a typical flora isolated from milks produced in a defined area $\mathrm{A}$ can be added to a MF milk obtained in another area B, even very far from A. That will originate a cheese in area $B$ which has the same typicity as cheeses produced in area $\mathrm{A}$. One sees easily the legal problems which arise from this possibility and the extent of delocalizations which could be thus created.

\subsection{Selective separation of micellar casein}

When whole or skim milk (evidently Bactocatch ${ }^{\circledR}$ treated skim milk) is circulated along a MF membrane with a pore size diameter of $0.1-0.2 \mu \mathrm{m}$, a microfiltrate with a composition close to that of sweet whey is obtained [9]. This microfiltrate is crystal clear and it can be sterile and claimed without any viral particle [12] if the downstream equipment prevents recontamination. The MF retentate is an enriched milk solution of native micellar casein. Excepting the pore size of the MF membrane, engineering characteristics of the technology are the same as those used for bacteria removal of milk i.e. use of a device leading to a uniform transmembrane pressure, a retentate velocity of at least $7 \mathrm{~m} \cdot \mathrm{s}^{-1}$ and a running temperature of $50-55^{\circ} \mathrm{C}$. As proposed by Pierre et al. [38] and by Schuck et al. [48], purified micellar casein can be prepared according to this application of MF by following the process described in Figure 3 with three main steps:

(a) concentration of the MF retentate up to a VRF of 3-4;

(b) diafiltration of this MF retentate with 4 diavolumes of R.O. treated water;

(c) concentration of the diafiltered MF retentate up to a VRF of 6-7;

(d) spray-drying of the $6: 1 \mathrm{MF}$ retentate.

Many variants of this process can be envisaged such as use of UF instead of MF at step (c), diafiltration at lower or higher VRF or uses of saline or acid solutions for diafiltration instead of pure water. 
Debacterized skimmilk

T.S.: 92.9 g. $\mathrm{kg}^{-1}$

$\mathbf{N} \times$ 6.38: $35.94 \mathrm{~g} \cdot \mathrm{kg}^{-1}$

Casein: 27.4 g.kg

Cas/NT: 0.77

Ashes: $7.8 \mathrm{~g} . \mathrm{kg}^{-1}$

pH: 6.72

MF permeate

TS: $57.8{\mathrm{~g} . \mathrm{kg}^{-1}}^{-1}$

N x 6.38: 6.4 g. $\mathrm{kg}^{-1}$

Ashes: 4.7 g. $\mathrm{kg}^{-1}$

pH: 6.69

Figure 3. Micellar casein making process.

Figure 3. Procotole de fabrication de la caséine micellaire.

Diafiltration retentate

T.S.: $103.4{\mathrm{~g} . \mathrm{kg}^{-1}}^{-1}$

N x 6.38: $91.8{\mathrm{~g} . \mathrm{kg}^{-1}}^{-1}$

Ashes: $8.5{\mathrm{~g} . \mathrm{kg}^{-1}}^{-1}$

pH: 6.96

Microfiltration

Retentate FCV 6

T.S.: $204.7{\mathrm{~g} . \mathrm{kg}^{-1}}^{-1}$

N x 6.38: $184.5{\mathrm{~g} . \mathrm{kg}^{-1}}^{-1}$

Casein: $177.9 \mathrm{~g} . \mathrm{kg}^{-1}$

Cas/NT: 0.96

Ashes: 18.8 g. kg

pH: 7.2

Powder

T.S.: 927.1 g. $\mathrm{kg}^{-1}$

N x 6.38: $821.9{\mathrm{~g} . \mathrm{kg}^{-1}}^{-1}$

Casein: $789.5 \mathrm{g.kg}^{-1}$

Cas/NT: 0.96

Ashes: 77.3 g.kg-1

pH: 7.2 
Micellar casein enriched milk improves cheesemaking process. Survey of the studies of Caron et al. [2], Saint-Gelais et al. [46] and Daviau et al. [4] demonstrates that such a MF milk coagulates slightly faster and leads to a more rigid curd (increase of the Young modulus with a coefficient of $30.5 \times 10^{3}$ Pa per g of casein perkg of milk) and firmer curd (increase of fracture stress with a coefficient of $2.55 \times 10^{3} \mathrm{~Pa}$ per $\mathrm{g}$ of casein per $\mathrm{kg}$ of milk). The yield increase in Camembert cheesemaking was $5.6 \mathrm{~g} \cdot \mathrm{kg}^{-1}$ per $g$ of casein increase in cheese milk [4].

Micellar casein powder which, to our knowledge, is not yet produced at an industrial scale, has large potentialities to be used for fortifying cheese milk, for replacing cheese curd in process cheese formulations. It also constitutes an excellent raw material for preparing individual caseins $(\beta-\mathrm{CN}$ notably) or $\kappa$-glycomacropeptide [28] in a strategy to produce purified nutraceutical derivatives from milk proteins [27].

On the other hand, partial removal by MF of whey proteins significantly reduces the detrimental effects of heating on rennet coagulability and cheese abilities of milk. To decrease the $\kappa$-casein/ $\beta$-lactoglobulin ratio will evidently lower the extent of formation of their complex during the heat treatment and consequently renneted micelles will aggregate almost as well as in raw milk [43]. This result was used to develop a new medium heat powder with such a cheesemaking ability that it can be used after reconstitution for the production with higher yields and good flavor characteristics of any cheese variety [11].

\subsection{Selective fractionation of globular milk fat}

Separation of milk fat in small globules and in large globules was recently proposed by Goudédranche et al. [17] through the use of special ceramic MF membranes which cause very low damage of the native globular membrane. It was claimed by the authors of this patented process that milks containing as fat only globules with a diameter lower than $2 \mu \mathrm{m}$ led to smoother and finer textural characteristic dairy products: cream, liquid milk, cheese etc. than those made from reference milks or from milks containing large fat globules with the exception of butter. The observed results were ascribed to the ability of fat globule membrane components to bind water and to the difference in triglycerides composition.

\subsection{Fat removal of whey}

The need to remove fat in whey protein concentrates was highlighted by de Wit [5] through his systematic approach to evaluation of functional properties notably the suitability of these dairy products as whipping ingredients. Numerous studies have been done to optimize the total removal of whey residual fat by $\mathrm{MF}$ after an aggregation pretreatment developed according to the results of Pearce [36], Maubois et al. [29], Baumy et al. [1], Gésan [13], Daufin et al. [3], and Pierre et al. [39]. The optimized procedure was described by Maubois and Ollivier [28]. It includes: (a) preconcentration by UF of the whey to $25 \%$ of its initial volume at $50{ }^{\circ} \mathrm{C}$; (b) removal of microorganisms by MF with a $0.8 \mu \mathrm{m}$ MF membrane set in an UTP equipment; (c) adjustment of temperature to $55^{\circ} \mathrm{C}$ and $\mathrm{pH}$ to 7.5 , this $\mathrm{pH}$ value being constantly maintained and (d) separation of the aggregated calcium phospholipid complex by MF with a $0.1 \mu \mathrm{m}$ pore size membrane set up in a UTP equipment. The so-obtained defatted whey concentrated by UF to a protein content of $10 \%$ shows foaming properties identical to egg white.

\subsection{MF and microbial fermentations}

As reviewed by Kulozik [21], membrane technologies and especially MF can be profitably incorporated in the upstream and downstream processing of the fermentation broth either in discontinuous operations for 
separating the biomass from the produced metabolites or in continuous fermentation processes. For example, MF equipment with a $0.1 \mu \mathrm{m}$ pore size membrane are connected to the fermentor to introduce aseptically sterile thermolabile components such as vitamins or salts. MF with $1.4 \mu \mathrm{m}$ ceramic membranes can achieve cell harvesting of starter bacteria with final concentration of the biomass increased to $10^{12}-10^{13} \mathrm{CFU} \cdot \mathrm{mL}^{-1}$ (Rolland and Proudy, data not published).

As well as the applications of MF in biofermentations of milk components, this separation technology has a great potential alone or in combination with nanofiltration (NF) for the treatment of dairy wastes through the carrying-out of membrane bioreactors. Indeed, activated sludges confined in a MF loop can easily degrade biological content of dairy effluents and thus restitute purified water to the environment.

\subsection{Cheese brine purification}

Efficient sanitation of cheese brine is required in the dairy industry in order to prevent post contamination of cheeses during salting. It is effectively well demonstrated that brine may contain unwanted microorganisms such as gas-producing lactobacilli, pathogenic bacteria (Staphylococci, Listeria and others) yeast and molds [35, 37]. As well as its bacterial load, the overall quality of brine and consequently the quality of the cheese salting, results from a relatively delicate balance equilibrium between $\mathrm{NaCl}$ content (18 to 26\%), soluble and precipitated $\mathrm{Ca}$ salts, lactose and lactic acid soluble and denaturated whey proteins.

Heat treatment and Kieselguhr filtration are still the most well-used technologies for brine treatment but both present many disadvantages: heat treatment requires expensive plate heat exchangers to avoid corrosion of usual stainless steel and modifies to an undesired extent the calcium phosphate equilibrium. Kieselguhr filtration needs manual handling, its dust is suspected to be carcinogenic [35] and anyway, disposal of Kieselguhr will be totally forbidden by law in European countries in 2002 for environmental reasons.

MF in a UTP equipment with a pore size of $1.4 \mu \mathrm{m}$ or $0.8 \mu \mathrm{m}$ membrane completely rejects yeasts and moulds, retains $99.9 \%$ of the contamination bacteria and only $6.7 \%$ of the calcium salts and $2-3 \%$ of the nitrogen matter [37]. The flux at $20^{\circ} \mathrm{C}$ was $600 \mathrm{~L} \cdot \mathrm{h}^{-1} \cdot \mathrm{m}^{-2}$ during $8 \mathrm{~h}$ and the concentration factor higher than 1:100.

From these very satisfactory results, it is likely that MF of cheese brine will expand rapidly if the investment cost of UTP ceramic membranes decreases as it can be expected.

\section{CONCLUSION}

With the use of membrane microfiltration technology, the world dairy industry has today a new powerful and flexible tool for a dramatic improvement of the hygienic safety of all dairy products while applying a minimal heat treatment to the milk. Consequently, it can be expected that nutritional and bioactive properties of milk components will be kept intact or at least little damaged in products derived from MF milk: liquid milks, cheeses, powders, fermented products, etc. Removal of bacterial and somatic cells with their endogenous thermoduric enzymes offers moreover to dairy research the chance to determine without any bias the precise activity versus storage time and temperature conditions of endogenous milk enzymes. The same research area is also opened for studying the metabolic consequences of each component of the microbial ecosystem added to MF cheesemilks.

Specific separations of micellar casein and of small and large fat globules open to dairy technology new and diversified avenues not only for improving current manufacturing processes, and consequently overall quality of resulting products, but also for 
creating new milk derivatives answering to the constant needs of novelty of the world dairy consumers.

\section{ACKNOWLEDGEMENTS}

Funding support of Ms Luciana Saboya's grant by CAPES and FAPESP is greatly acknowledged.

\section{REFERENCES}

[1] Baumy J.J., Gestin L., Fauquant J., Boyaval E., Maubois J.L., Technologies de purification des phospholipides du lactosérum, Process 1047 (1990) 29-33.

[2] Caron A., Saint Gelais D., Pouliot Y., Coagulation of milk enriched with ultrafiltered or diafiltered microfiltered milk retentate powders, Int. Dairy J. 9 (1997) 445-451.

[3] Daufin G., Labbé J.P., Quemerais A., Michel F., Merin U., Optimizing clarified whey ultrafiltration: influence of pH, J. Dairy Res. 61 (1994) 355-363.

[4] Daviau C., Effet des caractéristiques physicochimiques du lait sur l'aptitude à la coagulation présure et à l'égouttage dans une technologie pâte molle, Ph.D. thesis, INRA, Rennes, France, 2000.

[5] de Wit J.N., Functional properties of whey proteins in food systems, Neth. Milk Dairy J. 38 (1984) 71-89.

[6] Demarigny Y., Rôle de la flore naturelle du lait cru et de paramètres technologiques (teneur en sel et température d'affinage) sur l'évolution des caractéristiques biochimiques, microbiologiques et sensorielle des fromages à pâte cuite, Ph.D. thesis, INRA, Poligny, France, 1997.

[7] Eino M.F., Lessons leamed in commercialization of microfiltered milk, Bull. lnt. Dairy Fed. 320 (1997) 32-36.

[8] Fauquant J., Vieco E., BruléG., Maubois J.-L., Clarification des lactosérums doux par agrégation thennocalcique de la matière grasse résiduelle, Lait 65 (1985) 1-20.

[9] Fauquant J., Maubois J.-L., Pierre A., Microfiltration du lait sur membrane minérale, Tech. Lait. 1028 (1988) 21-23.

[10] Garcera D., Toujas E., (Société des Céramiques Techniques) Support macroporeux à gradient de perméabilité et son procédé de fabrication, Demande de Brevet No. 97.04.359, 1998.

[11] Garem A., Schuck P., Maubois J.-L., Cheesemaking properties of a new dairy-based power made by a combination of microfiltration and ultrafiltration, Lait 80 (2000) 25-32.
[12] Gautier M., Rouault A., Méjean S., Fauquant J., Maubois J.-L., Partition of Lactococcus lactis bacteriophage during the concentration of micellar casein by tangential $0.1 \mu \mathrm{m}$ pore size microfiltration, Lait 74 (1994) 419-423.

[13] Gésan G., Daufin G., Merin U., Labbé J.P., Quémerais A., Fouling during constant flux cross-flow microfiltration of pretreated whey. Influence of transmembrane pressure gradient, J. Membr. Sci. 80 (1993) 131-146.

[14] Gillot J., Garcera D., New ceramic filter medium for cross-flow microfiltration, in: FILTRA Congress, Paris, France, 1984, pp. 2-4.

[15] Gillot J., Garcera D., Ceraver: nouveaux médias filtrants céramiques, Tech. Lait. 1007 (1986) 23.

[16] Glimenius A.R., Jansson G.T., Kemi K.W., Sandblom R.M., Filtering method for separating skim milk from milk products, US Pat. No. 4.140.806, 1979.

[17] Goudédranche H., Fauquant J., Maubois J.-L., Fractionation of globular milk fat by membrane microfiltration, Lait 80 (2000) 93-98.

[18] Grandison A.S., Finnigan T.J.A., Microfiltration, in: Grandison A.S., Lexis M.J. (Ed.), Separation process in the food and biotechnology industries, Woodhead Publ. Ltd., Cambridge, England, 1996, pp. 141-153.

[19] Holm S., Malmberg R., Svensson K., Method and plant for producing milk with a low bacterial content, Eur. Pat. No. 0.194.286, 1984.

[20] Jost R., Jelen P., Cross-flow microfiltration an extension of membrane processing of milk and whey, Bull. Int. Dairy Fed. 320 (1997) 9-15.

[21] Kulozik U., Membranes in microbial fermentations, Bull. Int. Dairy Fed. Special issue 9201 (1992) 141-160.

[22] Law B.A., Goodenough P.W., Enzymes in milk and cheese production, in: Tucker G.A., Woods L.F.J. (Eds.), Enzymes in Food Processing, Blackie Acad. \& Professional, Glasgow, UK, 1995, pp. 114-143.

[23] Lindquist A., A method for the production of sterile skimmed milk, PCT Pat. WO No. 57549, 1998.

[24] Madec M.N., Méjean S., Maubois J.-L., Retention of Listeria and Salmonella cells contaminating skim milk by tangential membrane microfiltration (Bactocach process), Lait 72 (1992) 327-332.

[25] Malmberg M., Holm S., Low bacteria skim milk by microfiltration, North Eur. Food Dairy J. 54 (1998) 75-78.

[26] Maubois J.-L., Current uses and future perspectives of MF technology in the dairy industry, Bull. Int. Dairy Fed. 320 (1997) 37-40.

[27] Maubois J.-L., Léonil J., Peptides du lait à activité biologique, Lait 69 (1989) 245-269.

[28] Maubois J.-L., Ollivier G., Extraction of milk proteins, in: Damodaran S., Paraf A. (Eds.), Food proteins and their applications, Marcel Dekker, Inc., New York, 1997, pp. 579-595. 
[29] Maubois J.-L., Pierre A., Fauquant J., Piot M., Industrial fractionation of main whey proteins, Bull. Int. Dairy Fed. 212 (1987) 154-159.

[30] Maubois J.-L., Caudron B., Daviau C., Madec M.N., Pierre A., Membrane technologies: tools for a total control of the cheesemaking process, IDF Banff 2000 Seminar.

[31] Meershon M., Nitrate free cheesemaking with Bactocatch, North Eur. Food Dairy J. 55 (1989) 108-113.

[32] Merin U., Bacteriological aspects of microfiltration of cheese whey, J. Dairy Sci. 69 (1986) 326-328.

[33] Merin U., Gordin S., Tanny G.B., Microfiltration of sweet cheese whey, J. Dairy Res. 18 (1983) 153-160.

[34] Osterland N., Removal of bacteria and spores from milk by microfiltration, in: Proc. INRA Int. Dairy Fed. Seminar, New applications of membrane technology in the dairy industry, Saint Malo, France, 1999, p. 18.

[35] Ottosen N., Konigsfeld P., Microfiltration of cheese brine, Eur. Dairy Mag. 4 (1999) 22-24.

[36] Pearce R.J., Thermal separation of $\beta$-lactoglobulin and $\alpha$-lactalbumin in bovine Cheddar cheese whey, Aust. J. Dairy Technol. 42 (1983) 75-78.

[37] Pedersen P.J., Microfiltration for the reduction of bacteria in milk and brine, Bull. Int. Dairy Fed. Special issue 9201 (1992) 33--50.

[38] Pierre A., Fauquant J., Le Graet Y., Piot M., Maubois J.-L., Préparation de phosphocaséinate natif par microfiltration sur membrane, Lait 72 (1992) 461-474

[39] Pierre A., Le Graet Y., Daufin G., Michel F., Gésan G., Whey microfiltration performance: influence of protein concentration by ultrafiltration and of physicochemical pretreatment, Lait 74 (1994) 65-77.

[40] Pierre A., Goudédranche H., Garem A., Daufin G., Industrie Laitière, in: Daufin D., René F., Aimar P. (Coords.), Les séparations par membrane dans les procédés de l'industrie alimentaire, Tec. Doc. Lavoisier, Paris, 1998, pp. 282-371.
[41] Piot M., Maubois J.-L., Schaegis P., Veyre R., Microfiltration en flux tangentiel des lactosérums de fromagerie, Lait 64 (1984) 102-120.

[42] Piot M., Vachot J.C., Veaux M., Maubois J.-L., Brinkman G.E., Écrémage et épuration bactérienne du lait entier cru par microfiltration sur membrane en flux tangentiel, Tech. Lait. Market. 1016 (1987) 42-46.

[43] Quiblier J.P., Ferron-Baumy C., Garric G., Maubois J.-L., Procédé de traitement des laits permettant au moins de conserver leur aptitude fromagère, Brevet Fr. No. 0.542.583 B1, 1992.

[44] Rios G.M., Tarodo de la Fuente B., Bennasar M., Guidard C., Cross-flow filtration of biological fluids on inorganic membranes: A first state of the art, in: Thorne S. (Ed.), Developments in Food Preservation, Elsevier Applied Science, London, UK, 1989, pp. 131-175.

[45] Russell P., A new fresh milk comes to Britain, Eur. Dairy Mag. 3 (1999) 25-27.

[46] Saint-Gelais D., Roy D., Audet P., Manufacture and composition of low fat Cheddar cheese from milk enriched with different protein concentrate powders, Food Res. Int. 31 (1998) 137-145.

[47] Sandblom R.M., Filtering process, SW Pat. No. 74.16.257, 1974

[48] Schuck P., Piot M., Méjean S., Le Graet Y., Fauquant J., Brulé G., Maubois J.-L., Déshydratation des laits enrichis en caséine micellaire par microfiltration, comparaison des proprietés des poudres obtenues avec celles d'une poudre de lait ultra-propre, Lait 74 (1994) 47-63.

[49] Schuck P., Piot M., Méjean S., Le Graet Y., Fauquant J., Brulé G., Maubois J.-L., Déshydratation par atomisation de phosphocaséinate natif obtenu par microfiltration sur membrane, Lait 74 (1994) 375-388.

[50] Trouvé E., Maubois J.-L., Piot M., Madec M.N., Fauquant J., Rouault A., Tabard J., Brinkman G., Rétention de différentes espèces microbiennes lors de l'épuration du lait par microfiltration en flux tangentiel, Lait 71 (1991) 1-13.

[51] Vincens D., Tabard J., L'élimination des germes bactériens sur membranes de microfiltration, Tech. Lait. 1033 (1988) 62-64. 


\section{APÊNDICE 2}

"Efficient and easy mechanical disruption of Lactobacillus helveticus, Lactococcus lactis and Propionibacterium freudenreichii by a new pilot high-pressure homogenizer"

SABOYA, L.V.; MAILLARD, M.-B.; LORTAL, S.

Enviado para publicação no Journal of Microbiological Methods, 2001. 
Efficient and easy mechanical disruption of Lactobacillus helveticus,

Lactococcus lactis and Propionibacterium freudenreichii by a new pilot high pressure homogenizer

SABOYA Luciana Viriato', MAILLARD Marie-Bernadette ${ }^{2}$, and LORTAL Sylvie ${ }^{2} *$

'Escola Superior de Agricultura "Luiz de Queiroz" (ESALQ/USP), Av. Padua Dias 11, Caixa Postal 9 - Piracicaba, SP, 13418-900, Brasil

${ }^{2}$ Laboratoire de Recherches de Technologie Laitière,INRA 65 rue de St Brieuc, 35042 Rennes Cédex, France

Corresponding author: *lortal@ labtechno.roazhon.inra.fr 


\section{SUMMARY}

Aims Microbiological studies often involve bacterial cell fractionation, which is known to be difficult in gram (+) compared to gram (-) bacteria. Cell disruption can be achieved by various mechanical treatments. Our purpose was to test the breaking efficiency of a new high pressure pilot homogenizer toward gram $(+)$ species.

Methods and results Varied pressures (50,100 and $200 \mathrm{MPa}$ ) were applied to concentrated bacterial suspensions (1.2 $\mathrm{mg}$ dry weight $/ \mathrm{ml}$ ) of Lactobacillus helveticus, Lactococcus lactis and Propionibacterium freudenreichii. The breaking efficiency was estimated by the decrease of optical density at $650 \mathrm{~nm}$, of cellular dry weight and of viability. The proteins released were quantified and the residual activity of an intracellular aminotransferase was estimated. One run at $50 \mathrm{MPa}$ was sufficient to break $80 \%$ of lactobacilli cells whereas $200 \mathrm{MPa}$ were required for the same efficiency for $L$. lactis and P. freudenreichii. Whatever the pressure, leucine aminotransferase activity was recovered in the supernatant of breaking.

Conclusions This new high pressure pilot homogenizer can allow a rapid (20 s/run), easy, continuous and highly efficient cell breaking.

Significance and impact of the study As the species tested were not phylogenetically related, having different morphologies and cell wall composition, we conclude that most gram (+) bacteria can be efficiently broken by this new device.

Keywords: cell disruption; high pressure homogenizer; aminotransferase; protein release, Propionibacterium, Lactobacillus, Lactococcus. 


\section{INTRODUCTION}

Microbiological studies often involve bacterial cell fractionation. This step is required to recover intracellular enzymes or low molecular weight compounds. It is also required in cell wall preparation for subsequent chemical characterization (Salton and Horne, 1951) or for studying cell wall associated enzymes like autolysins (Rogers, 1980). By contrast to gram (-) bacteria, gram (+) bacteria are not easily disrupted due to their thick multilayered peptidoglycan.

Bacterial cell disruption can be achieved by either mechanical or enzymatic treatments. On a laboratory scale, disruption is provoked by different kinds of presses (French press, X-press), by sonication, by grinding with alumina, or by vortexing with glass beads (Mc lwain, 1948; French and Milner, 1955, Hummel and Kula, 1989). For most gram (+) species, the efficiency of disruption rarely overtake 50 $\%$ of the initial cell number in one run. Thus, preparation of large amounts of gram (+) cell wall by this way can be very tedious and time consuming. Enzymatic treatments exist as a mild alternative involving either lysozyme (muramidase, EC 3.2.1.17), mutanolysin (Yokogawa et al., 1975 ; Siegel et al., 1981) or purified phage endolysins (like lysostaphin), all hydrolysing peptidoglycan bonds. Less denaturing compared to physical disruption, these treatments require often an optimisation for each species and sometimes for each strain (Chassy and Giuffrida, 1980). Moreover, peptidoglycan (O or $\mathrm{N}$-acetylated) can be resistant to lysozyme activity and thus require the use of mutanolysin, which is a rather expensive lytic enzyme. Of course, lytic enzymatic treatments are excluded if the purpose is to isolate cell walls and in particular peptidoglycan sacculi.

High-pressure homogenizers appeared in the 70s years. The mechanical principle of cell breaking was the same as the French press (explosive decompression) but compared to all the methods cited, it is the only one working continuously. Because of that, large scale disruption processes often involved various homogenizers (Follows et al., 1971 ; Kula \& Schütte, 1987; Middelberg, 1995). However relatively few data exist in the literature. For example, homogenization was applied to E. coli, B. subtilis and one 
yeast in a commercial homogenizers at pressures around $55 \mathrm{MPa}$ leading to a rate of breaking from 12 to $67 \%$ in one pass depending on the type of organism and other factors (Gray et al. 1972; Higgins et al. 1978; for review see Engler, 1981).

Today, pilot high-pressure homogenizers delivering instantaneous pressure as high as $350 \mathrm{MPa}$ and having new valve design are available. The present work reports experiments showing the disrupting efficiency of this new device toward gram $(+)$ species of various morphologies: Lactobacillus helveticus (rods), Lactococcus lactis (cocci) and Propionibacterium freudenreichii (chinese characters). Those species were chosen i) because of their morphology which could resist differently to pressure, and ii) for their wide use and interest in dairy technology, making frequent their fractionation to study intracellular enzymes. The results showed that whatever the species, high rate of cell breaking can be achieved in an easy and rapid way by this new homogenizer.

\section{MATERIAL AND METHODS}

\section{Origin and growth of the strains}

Lactobacillus helveticus CNRZ 243 and Lactococcus lactis NCDO 763 were obtained from CNRZ collection (INRA Jouy en Josas, France). They were stored at $-80^{\circ} \mathrm{C}$ in MRS broth with glycerol (Difco, Detroit, MI48232, USA) and in M17 (Terzaghi and Sandine, 1975), respectively. Propionibacterium freudenreichii TL 24 (CNRZ 725) was obtained from our laboratory collection (TL, INRA, Rennes) and was stored in sodium lactate broth (Malik et al., 1968). The media were supplemented with $15 \%$ glycerol prior freezing. For the propagation of the strains, respective media without glycerol were used and growth was monitored at $37^{\circ} \mathrm{C}$ for L. helveticus and at $30^{\circ} \mathrm{C}$ for the two other species, by optical density at $650 \mathrm{~nm}\left(\mathrm{OD}_{650}\right)$.

\section{Homogenization}

When O.D.650 1 was reached (dry weight of 0.25 to $0.35 \mathrm{mg} \cdot \mathrm{ml}^{-1}$ depending on the species), cells from one liter of culture were harvested by 
centrifugation $\left(9,000 \mathrm{~g}, 10 \mathrm{~min}, 4^{\circ} \mathrm{C}\right)$, washed two times in sterile distilled water and suspended in $240 \mathrm{ml}$ of sterile distilled water to achieve a cell concentration of about $10^{9}$ cfu. $\mathrm{ml}^{-1}$. Cell suspensions were maintained on ice until use. $15 \mathrm{ml}$ of the suspension was kept in the cold as the blank (To). The rest of the suspension was divided into 3 part of $75 \mathrm{ml}$ and submitted to the disrupting effect of the pilot homogenizer (Standsted, fluid power LTD) at pressure of 50,100 and $200 \mathrm{Mpa}$ under a cooling flow. $100 \mathrm{ml}$ of crude broken suspension were recovered in each case and kept on ice immediately. The diluting effect of homogenization was taken into consideration, i.e. the blank was diluted to the same extent (25\%) to allow comparisons with treated suspensions. A sample was centrifuged $\left(10,000 \mathrm{~g}, 10 \mathrm{~min}, 4^{\circ} \mathrm{C}\right)$ and the supernatant (cell free extract) was recovered for analysis. For each species, two independent assays of homogenization were done, and the average was presented in the results.

\section{Numeration}

Before and after homogenization treatment, cell viability was determined by plating on the respective media used for each species, containing $1.2 \%$ agar. Plates were incubated 2 days at $30^{\circ} \mathrm{C}$ for L. lactis and P. freudenreichii (anaerobiosis) and at $37^{\circ} \mathrm{C}$ for $L$. helveticus (anaerobiosis). The results were expressed as $\%$ of the initial viability.

\section{Cellular dry weight}

$3 \mathrm{ml}$ of cell suspensions (blank and after homogenization) were centrifuged $\left(10,000 \mathrm{~g}, 10 \mathrm{~min}, 4^{\circ} \mathrm{C}\right)$. The pellet was washed once in sterile cold distilled water and kept at $-18^{\circ} \mathrm{C}$ until dried on a Speed Vac equipment (Savant Instruments, New York) and weighted to estimate residual cellular dry weight. The supernatant was kept for protein measurement, SDS-PAGE, and leucine aminotransferase analysis.

\section{Protein measurement}

The absorbance of the supernatant at $280 \mathrm{~nm}$ was measured using a spectrophotometer DU 7400 (Beckman). The protein content was also determined by the 
Bradford (1976) procedure using the Biorad assay kit (Biorad microprocedure, Hercules, CA, USA), with bovine serum albumin (Sigma) as standard.

\section{SDS-PAGE}

SDS-PAGE was performed using a $14 \%$ acrylamide separating gel $(8 \times 8$ $\mathrm{cm}$ ) and a $4 \%$ acrylamide stacking gel as previously described (Valence and Lortal, 1995). Electrophoresis was performed at $180 \mathrm{~V}$ during $1 \mathrm{~h}$. Samples were suspended v/v in Laemmli buffer (Laemmli, 1970) and boiled 3 min before loading. Gels were stained using Coomassie blue R250.

\section{Leucine aminotransferase activity}

Leucine aminotransferase activity was assayed according to Yvon et al., 1997. $20 \mu l$ of cell free extract (supernatant of homogenization) were added to $150 \mu \mathrm{l}$ of reaction mixture : Tris- $\mathrm{HCl}$ (Merck) $70 \mathrm{mM} \mathrm{pH} 8.0$ containing $4 \mathrm{mM}$ leucine (Sigma), $10 \mathrm{mM}$ sodium $\alpha$-ketoglutarate (Sigma), $50 \mu \mathrm{M}$ Pyridoxal 5'-phosphate (Sigma). Incubation was performed during 2 to 18 hours at $37^{\circ} \mathrm{C}$. Glutamic acid was enzymatically analysed with Boerhinger kit (Diffchamb, Lyon, France). A blank without amino acid was included as control. Reagents: Leucine, $\alpha$-ketoglutarate, pyridoxal 5'phosphate were obtained from Sigma Aldrich (St Quentin, Fallavier, France).

\section{RESULTS AND DISCUSSION}

\section{Cell breaking efficiency}

For the three species, the indices of cell breaking were all in agreement: the decrease in OD $650 \mathrm{~nm}$, the cellular dry weight and cell numeration (Figure 1. a, b, c). The disrupting efficiency increased clearly with the pressure applied, but in three different manners. The tendency curves were, respectively, potential for $L$. helveticus, linear for L. lactis and logarithmic for $P$. freudenreichii. Indeed, more than $80 \%$ of broken cells can be obtained in one run at $50 \mathrm{MPa}$ for $L$. helveticus whereas a pressure 
as high as $200 \mathrm{MPa}$ was necessary for P. freudenreichii and L. lactis. The repetition of the treatment at $200 \mathrm{MPa}$ in the case of propionibacteria only led to a slight increase of cell breaking (Figure 1c). Lanciotti et al. (1994) when applied pressures ranging from 15 to $200 \mathrm{MPa}$ on food spoilage and pathogenic micro-organisms observed a log-linear relationship between surviving cells and pressure applied. According to Engler (1985), the shape and strength of microbial cell walls appear to depend on the structural polymers within the wall and the degree to which they are cross-linked to one another and to other wall components. To disrupt a cell, the major resistance which must be overcome is the covalent bonding of this structural network. To the best of our knowledge, the mechanism of cell disruption by high-pressure homogenisation was only recently more deeply investigated and only for one yeast (Kleinig and Middelberg, 1998). In our case, the shape seemed to have a significant effect on the breaking efficiency since rods (lactobacilli) were much more fragile toward homogenization compared to cocci (Lactococcus) or to pleiomorphic cells like propionibacteria. Interestingly, the percent of residual viability was similar to the one of the cellular dry weight which would indicate that most of the non broken cells are not drastically damaged but still alive and viable. This point could be easily confirmed by fluorescence microscopy using live/dead staining.

Lastly, ten fold concentrated suspensions of propionibacteria was submitted to homogenization at $200 \mathrm{Mpa}$ and the same disruption efficiency was obtained (data not shown). This result was in agreement with the literature indicating that performance of homogenizers did not diminish with increasing cell concentration until concentration-related blockages made operation impractical (Engler, 1985).

\section{Analysis of the proteins released in the supernatant of homogenization}

Whatever the method used $\left(\mathrm{A}_{280} \mathrm{~nm}\right.$, protein estimation or SDS-PAGE), no protein was detected in the supernatant of the blank. Moreover, in the supernatant of homogenized suspensions, the increase of the quantity of protein released was shown to be coherent and symmetric with the percent of cell breaking for each species (Figures 2 and 3). It was for example obvious, whatever the method used, that most of the $L$. 
helveticus proteins were already released by a treatment of $50 \mathrm{Mpa}$, which is coherent with the already high breaking efficiency at this pressure for that species ( $>80 \%)$. On the other hand, surprisingly, in the case of propionibacteria $25-30 \%$ less protein was released compared to lactococci, for the same breaking efficiency (at 100 and $200 \mathrm{Mpa}$ ). This might reflect differences in the ratio cell envelope/ cytoplasmic proteins since the former were shown to be released easier and faster through a homogenizer treatment (Engler, 1985).

\section{Recovery of leucine aminotransferase activity}

L. helveticus, L. lactis and P. freudenreichii all possess intracellular Leu aminotransferase activity which were shown to have a key role in ripening cheese and are actually the object of numerous studies (Yvon, et al.1997; Klein et al. 2001; Thierry et al., 2001). In order to assess the impact of homogenization on that intracellular enzyme, the activity was estimated per mg of protein released. Whatever the species and even at the highest pressure, leucine aminotransferase activity was detected in the supernatant (Figure 4) and no drastic loss of activity was noted for the two independent homogenization assays, even at the highest pressure.

\section{CONCLUSIONS}

The high pressure homogenizer pilot used was shown to be a very efficient method to break rapidly (few seconds), continuously and easily gram positive bacteria with three different morphologies. This can be attributed to the new ceramic decompression valve with a sharp design and also the ability to deliver very high instantaneous pressure (until $350 \mathrm{Mpa}$, maximal values not tested here). For the three species investigated, the activity of an intracellular enzyme, the Leu aminotransferase, was recovered into the supernatant of breaking and resisted to the highest pressure applied (200 MPa). This makes likely the idea that this new pilot high pressure homogenizer can be a valuable device to prepare active cytoplasmic enzymes of gram positive bacteria. 


\section{REFERENCES}

Bradford, M. (1976) A rapid and sensitive method for the quantitation of microgram quantities of protein utilizing the principle of protein-dye binding. Analytical Biochemistry 72, 248-254.

Chassy, B.M. and Giuffrida, A. (1980) Method for the lysis of Gram-positive, asporogenous bacteria with lysozyme. Applied and Environmental Microbiology 39, 153-158.

Engler, C.R. (1985) Disruption of microbial cells. In Comprehensive biotechnology 2 ed. Moo-Yoong M., pp. 305-324. Pergamon Press.

Engler, E.R. and Robinson, C.W. (1979) New method of measuring cell-wall rupture. Biotechnology and Bioengineering 21, 1861-1869.

Follows, M.P.J., Hetherington, P., Dunnill, P. and Lilly, M.D. (1971) Release of enzymes from bakers'yeast by disruption in an industrial homogenizer. Biotechnology and Bioengineering 13, 549-560.

French, C.L. and Milner, H.W. (1955) Disintegration of bacteria and small particles by high pressure extrusion. Methods in Enzymology 1, 64-67.

Gray, P.P., Dunnill, P. and Lilly, M.D. (1972) The continuous-flow isolation of enzymes. In Fermentation Technology Today ed. Terui, G. pp. 347-351. Japan: Society for fermentation Technology. 
Higgins, J.J., Lewis, D.J., Daly, H.W., Mosqueira, F.G., Dunnill, P. and Lilly, M.D. (1978) Investigation of the unit operations involved in the continuous flow isolation of ß-galoctosidase from Escherichia coli. Biotechnology and Bioengineering 20, 159-182.

Hummel, W. and Kula, M.R. (1989) Simple method for small-scale disruption of bacteria and yeasts. Journal of Microbiology Methods 9, 201-209.

Klein, N., Maillard, M.-B., Thierry, A., Lortal, S. (2001) Conversion of amino acids into aroma compounds by cell-free extracts of Lactobacillus helveticus. Journal of Applied Microbiology 91, 1-8. in press

Kleinig, A.R. and Middelberg, A.P.J. (1998) On the mechanism of microbial cell disruption in high-pressure homogenisation. Chemical Engineering Science 53, 891-898.

Kula, M.-R. and Schütte, H. (1987) Purifications of proteins and the disruption of microbial cells. Biotechnology Progress 3, 31-42.

Laemmli, U.K. (1970) Cleavage of structural proteins during the assembly of the head of bacteriophage T4. Nature 227, 680-685.

Lanciotti, R., Sinigaglia, M., Angelini, P. and Guerzoni, M.E. (1994) Effects of homogeneization pressures on the survival and growth of some spoilage and pathogenic micro-organisms. Letters in Applied Microbiology 18, 319-322.

Malik, A.C., Reinbold, G.W. and Vedamuthu, E.R. (1968) An evaluation of the taxonomy of Propionibacterium. Canadian Journal of Microbiology 14, 1185-1191. 
McIllwain, H. (1948) Preparation of cell-free bacterial extracts with powdered alumina. Journal of General Microbiology 2, 288-291.

Middelberg, A.P.J. (1995) Process-scale disruption of microorganisms, Biotechnology Advances 13, 491-551.

Rogers H.J., Perkins H.R. and Ward, J.B. (1980) The bacterial autolysins. In Microbial Cell Walls and Membranes ed. Rogers, H.J., Perkins, H.R. and Ward, J.B. pp. 437-460. London: Chapman and Hall.

Salton, M.R.J. and Horne, R.W. (1951) Studies of the bacterial cell wall. II. Methods of preparation and some properties of cell walls. Biochimica and Biophysica Acta 7, 177197.

Siegel, J.L., Hurst, S.F., Liberman, E.S., Coleman, S.E. and Bleiweis, A.S. (1981) Mutanolysin-induced spheroplasts of Streptococcus mutans are true protoplasts. Infection and Immunity 31, 808-815.

Terzaghi, B.E., Sandine, W.E. (1975) Improved medium for lactic streptococci and their bacteriophages. Applied Microbiology 29, 807-813.

Thierry, A., Maillard, M.-B. and Yvon M., (2001) Conversion of L-Leucine to isovaleric acid by Propionibacterium freudenreichii TL 34 and ITGP23. Applied and Environmental Microbiology, submitted. 
Valence, F. and Lortal, S. (1995) Zymogram and preliminary characterization of Lactobacillus helveticus autolysins. Applied and Environmental Microbiology 61, 33913399.

Yokogawa, K., Kawata, T., Takesmura, T. and Yoshimura, Y. (1975) Purification and properties of lytic enzymes from Streptomyces globisporus 1829. Agricultural and Biological Chemistry 39, 1533-1543.

Yvon, M., Thirouin, S., Rijnen, L., Fromentier, D. and Gripon, J.C. (1997) An aminotransferase from Lactococcus lactis initiates conversion of amino acids to cheese flavor compounds. Applied and Environmental Microbiology 63, 414-419. 

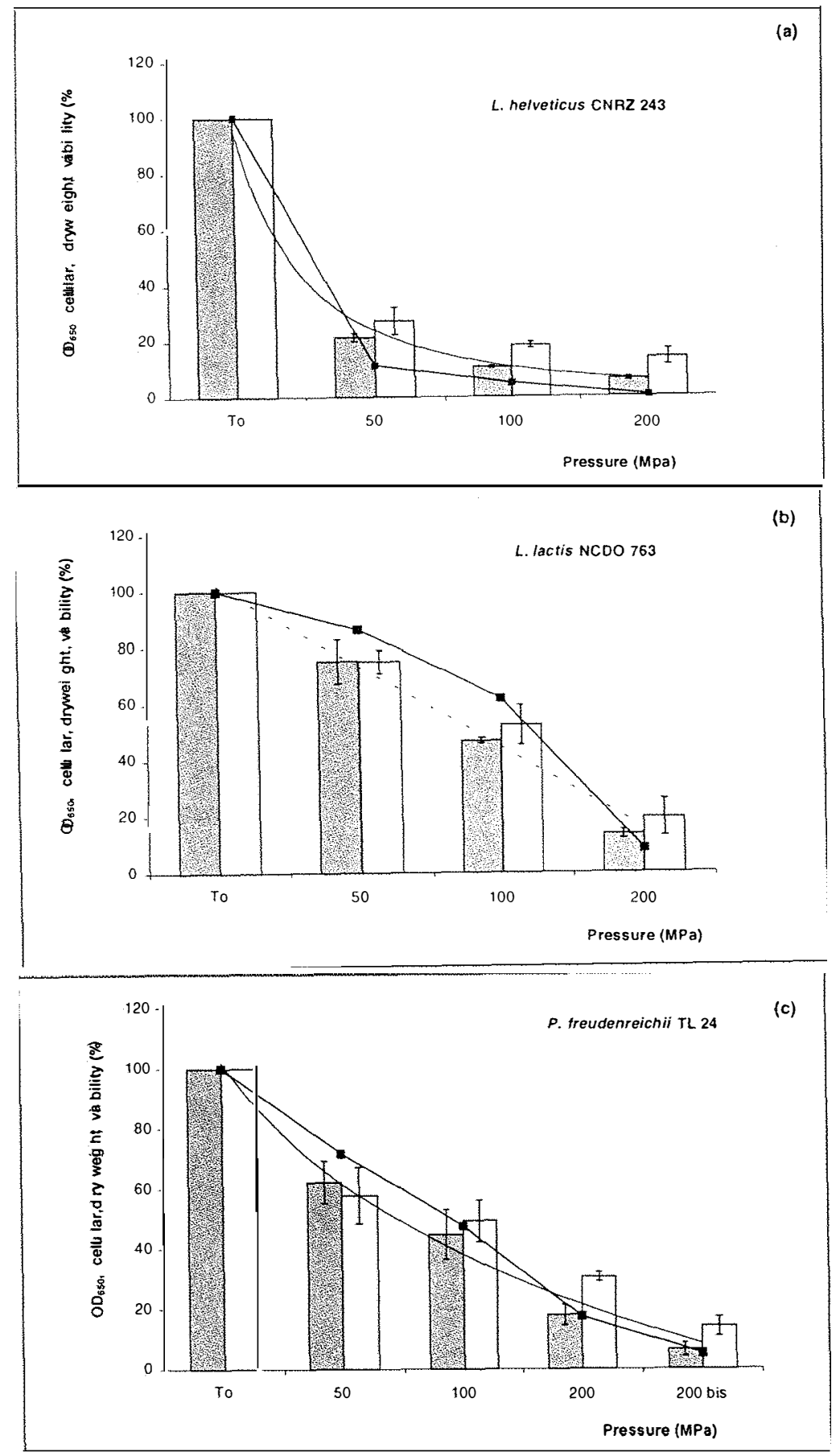

Figure 1. OD $650 \mathrm{~nm}$ (圆), cellular dry weight ( $\square$ ) and cell viability (-口-) of L. helveticus CNRZ 243 (a), L. lactis subsp. lactis NCDO 763 (b) and P. freudenreichii TL 24 (c) when submitted to Homogenization at pressures of 50, 100 and, $200 \mathrm{MPa}$. (...) Tendency curves. 

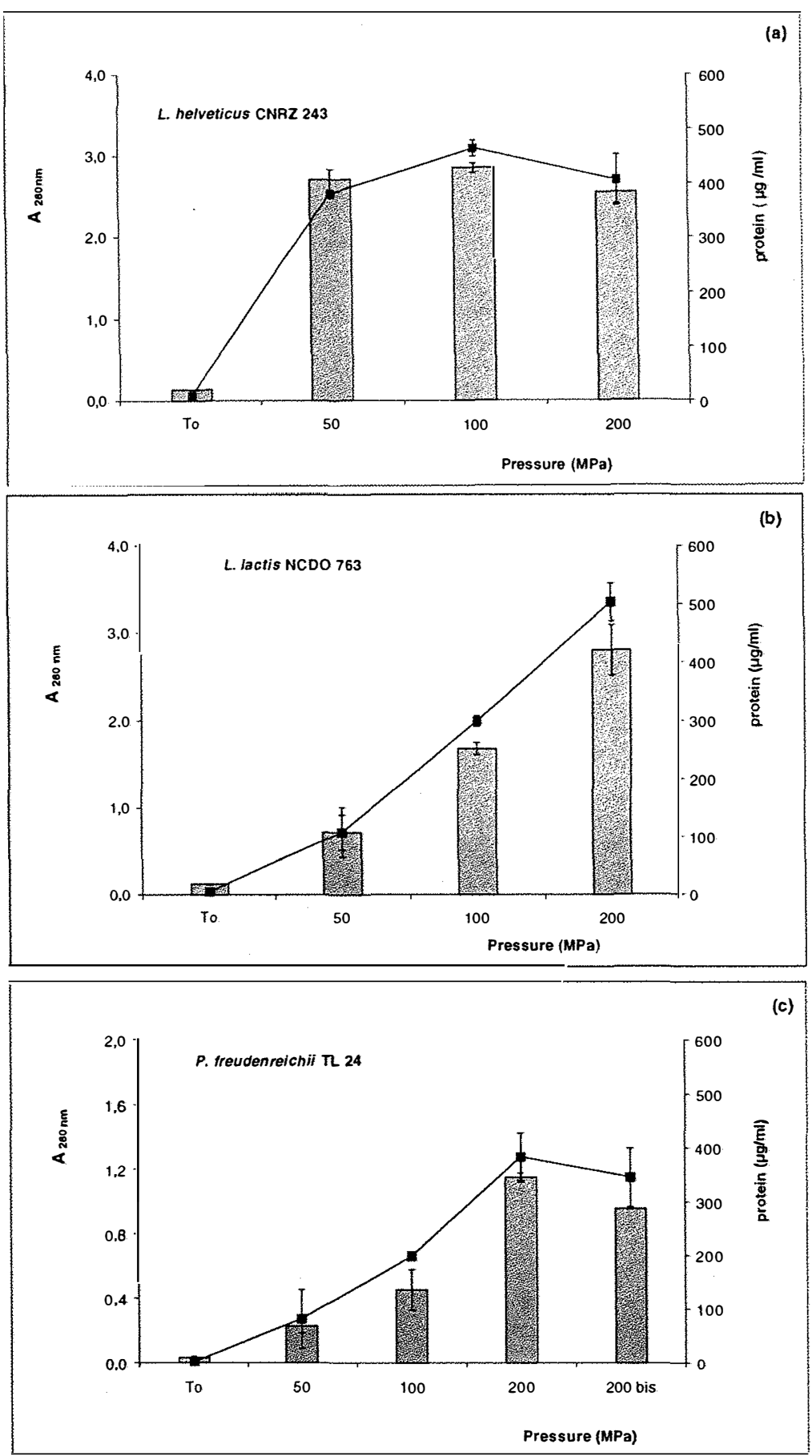

Figure 2. $\mathrm{OD}_{280 \mathrm{~nm}}$ (图), protein $(\mu \mathrm{g} / \mathrm{ml})(-)$ of $L$. helveticus CNRZ 243 (a), L. lactis subsp. lactis NCDO 763 (b) and $P$. freudenreichii TL 24 (c) when submitted to Homogenization at pressures of 50, 100 and, $200 \mathrm{MPa}$. 


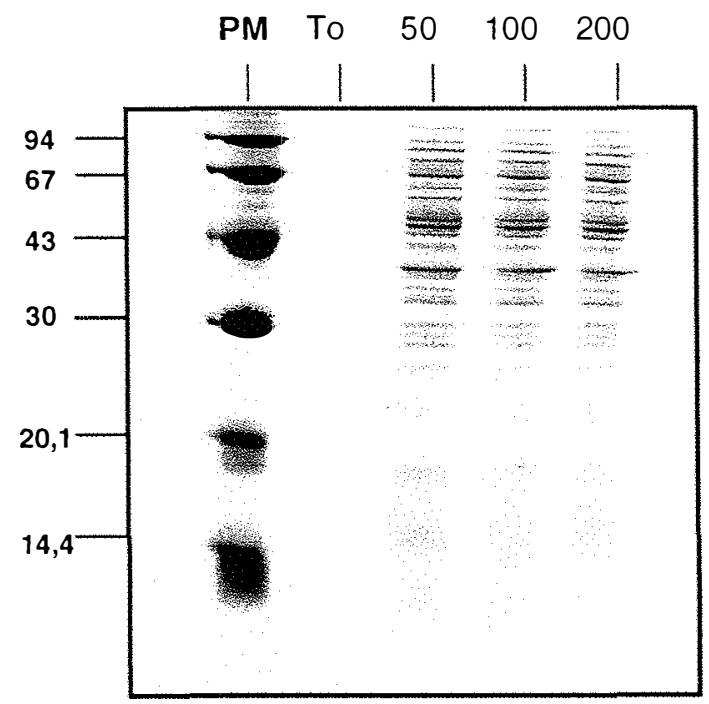

(a)

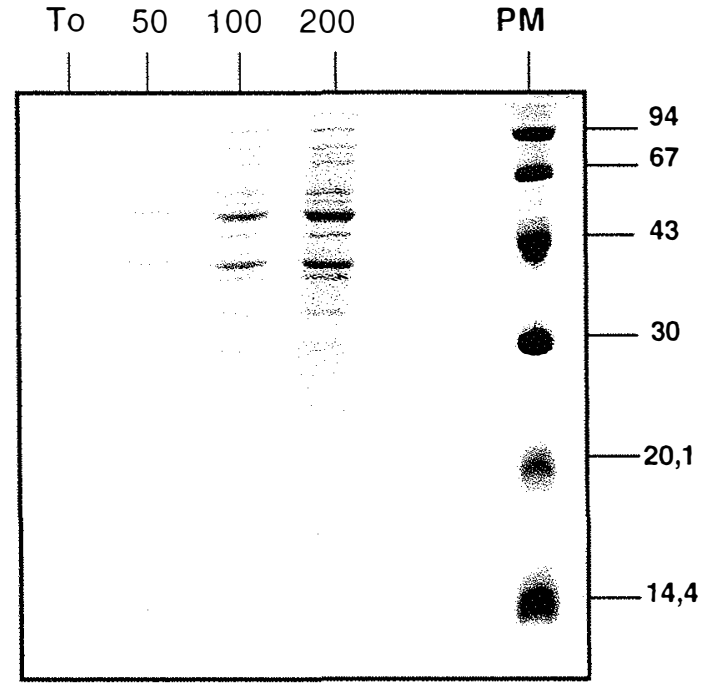

(b)

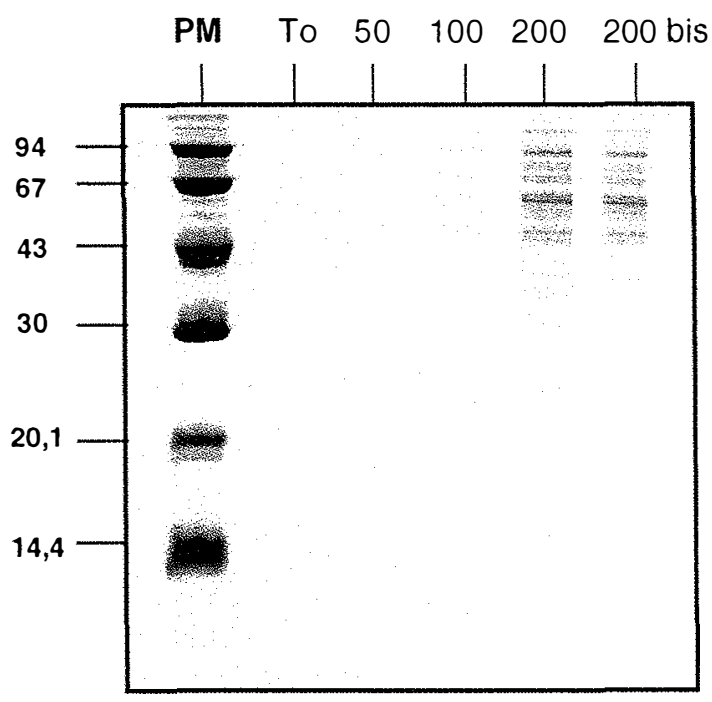

(c)

Figure 3. SDS-PAGE showing the proteins of L. helveticus CNRZ 243 (a), L. lactis subsp. lactis NCDO 763 (b), and P. freudenreichii TL 24 (c) released by homogenization depending on the pressure applied (indicated in each line). MW, standard molecular weights $(\mathrm{KDa})$. 


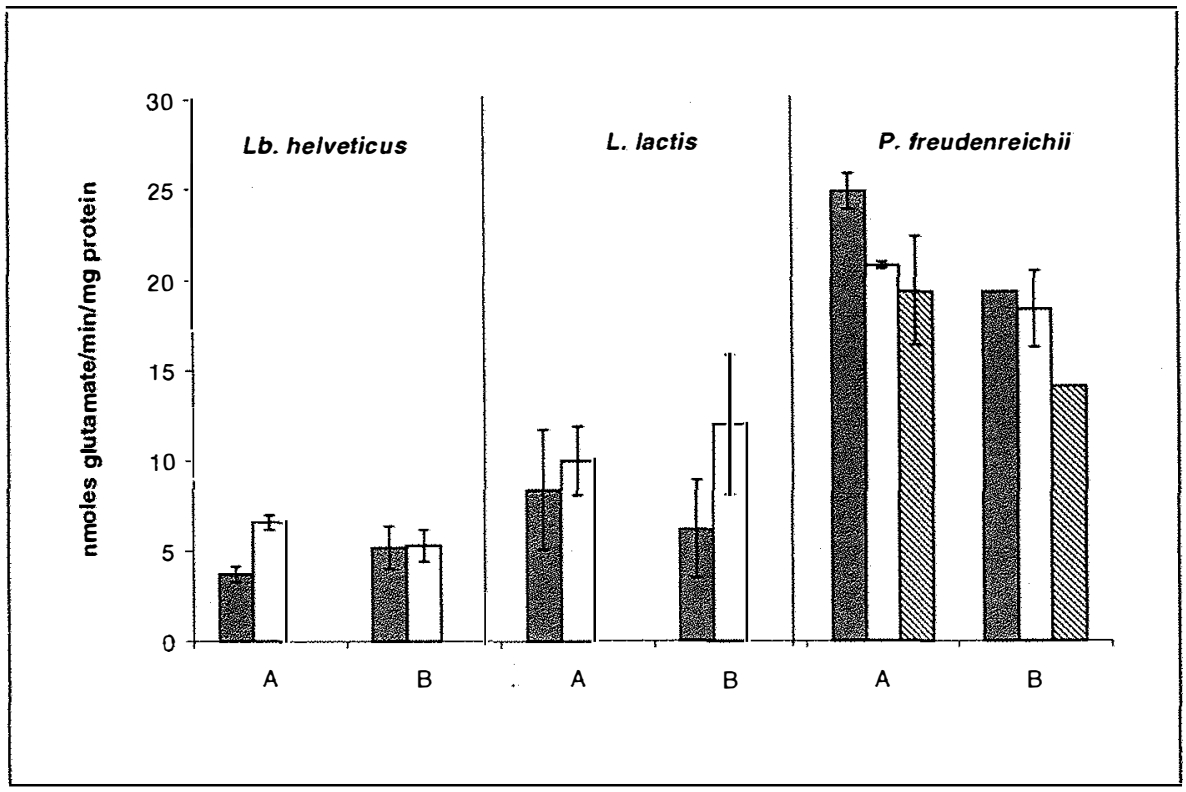

Figure 4. Leucine aminotransferase activity $(\mathrm{nmol} / \mathrm{min} / \mu \mathrm{g}$ protein) of cell free extract of $L$. helveticus CNRZ 243, L. lactis subsp. lactis NCDO 763 and $P$. freudenreichii TL 24, obtained by two different homogenizations (A and B) at pressures of $100($ 回), $200(\nabla)$ and, 200 MPA twice ( $\square)$. 


\section{APÊNDICE 3}

"Impact of broken cells of lactococci or propionibacteria on the ripening of SaintPaulin UF-cheeses: extent of proteolysis and GC-MS profiles" SABOYA, L.V.; GOUDEDRANCHE, H.; MAUBOIS, J.-L., LERAYER, A.L.S.; LORTAL, S.

Artigo publicado na Revista : Le Lait, v.81, p.699-713, 2001. 


\title{
Impact of broken cells of lactococci or propionibacteria on the ripening of Saint-Paulin UF-cheeses: extent of proteolysis and GC-MS profiles
}

\author{
Luciana Viriato SABOYA ${ }^{a}$, Henri GOUDÉDRANCHE ${ }^{b}$, \\ Jean-Louis MAUBois ${ }^{b}$, Alda Luiza Santos LerAyER ${ }^{c}$, Sylvie LORTAL b* \\ a Escola Superior de Agricultura "Luiz de Queiroz" (Universidade de São Paulo), \\ av. Pádua Dias 11, CEP 13418-900, Piracicaba, SP, Brasil \\ ${ }^{\mathrm{b}}$ Laboratoire de Recherches de Technologie Laitière, INRA, \\ 65 rue de Saint Brieuc, 35042 Rennes Cedex, France \\ ${ }^{\mathrm{c}}$ Instituto de Tecnologia de Alimentos - ITAL, \\ avenida Brasil 2880, CEP 13073-001, Campinas, SP, Brasil
}

(Received 16 July 2001; accepted 31 August 2001)

\begin{abstract}
UF-cheeses have been successfully developed in many countries. However, proteolysis and the general extent of ripening were shown to be far slower compared to traditional varieties. The absence of starter lysis has been cited as a plausible explanation. In this work, propionibacteria and lactococci cells were disrupted using a new pilot homogenizer. Crude broken suspension (CBS), or cell-free extract (CFE), obtained after centrifugation, were added to UF-St Paulin retentate (concentration factor 6) made with a usual lactic starter. $\mathrm{RO}$ water was added to the control. Proteolysis was estimated by NCN, NPN and free amino acids. Neutral volatile compounds were determined by GCMS. A low extent of ripening was noted in the control and the absence of starter lysis was effectively proved using immunodetection of lactococci cytoplasmic proteins. The addition of lactococci CBS or CFE increased free amino acid content ( 1.5 to 3 times) whereas propionibacteria CBS or CFE exhibited no significant increase, even when cheeses were ripened at $20^{\circ} \mathrm{C}$ instead of $12{ }^{\circ} \mathrm{C}$. By contrast, addition of propionibacteria CBS generated a significant increase in several volatile compounds like alcohols and ketones, whereas CFE did not, showing that the presence of live cells was required to form these compounds. CBS or CFE of lactococci did not significantly change the volatile compound profile. In conclusion, it was possible to influence the ripening of UF-cheese by the addition of crude broken bacterial cell suspensions. Other strains and species should now be investigated.
\end{abstract}

ultrafiltration / UF-cheese / GC-MS profile / broken cells / ripening / proteolysis / Lactococcus / propionibacteria

* Correspondence and reprints

Tel.: (33) 2234853 34; fax: (33) 2234853 50; e-mail: lortal@labtechno.roazhon.inra.fr 


\begin{abstract}
Résumé - Impact d'extraits cellulaires de lactocoques et de propionibactéries sur l'afiñage de fromages UF : étendue de la protéolyse et profils CG-MS. Les fromages UF se sont développés avec succès dans de nombreux pays. Cependant, sans action technologique complémentaire, la protéolyse et par conséquent l'affinage sont nettement plus lents que dans les produits obtenus par les procédés traditionnels. L'absence de lyse du levain pourrait constituer une des causes possibles. Dans ce travail, des cellules de P. freudenreichii et de Lactococcus sp. ont été " cassées " à l'aide d'un nouvel homogénéisateur pilote. Les suspensions cassées brutes (CBS) ou les extraits intracellulaires (CFE) obtenusaprès centrifugation, ont été ajoutés à des rétentats UF de type St Paulin (concentration $\times 6$ ) acidifiés à l'aide d'un levain lactique mésophile commercial. De l'eau osmosée était ajoutée au témoin. La protéolyse a été estimée par la mesure des teneurs en NCN, NPN et en acides aminés libres ; les composés volatilsneutres par CG-MS. Dans le témoin, cette protéolyse était très limitée et l'absence de lyse du levain commercial (L. lactis) a été effectivement démontrée. L'addition de CBS ou de CFE de Lactococcus augmentait la teneur en acides aminés libres ( 1,5 à 3 fois). Cet accroissement n'était pas observé lors de l'addition de CBS ou de CFE de P. freudenreichii, même lorsque la température d'affinage étaitélevée à $20^{\circ} \mathrm{C}$ au lieu de $12^{\circ} \mathrm{C}$. Par contre, l'addition de CBS de $P$. freudenreichii entraînait une augmentation des teneurs en produits volatils neutres : alcools et cétones. L'absence d'effet similaire avec le CFE montrait la nécessité de la présence de cellules entières. L'addition de CBS ou CFE de Lactococcus ne changeait pas significativement les teneurs en composés volatils neutres. En conclusion, l'addition d'homogénéisats de suspensions cellulaires peut modifier l'affinage des fromages UF. L'addition d'autres souches et d'autres espèces doit maintenant être explorée.
\end{abstract}

ultrafiltration / fromage UF / CG-MS profil / homogénéisats cellulaires / protéolyse / affinage / Lactococcus / propionibacteria

\section{INTRODUCTION}

Introduced 32 years ago by Maubois, Mocquot and Vassal [28], the MMV process has achieved successful commercial development for many cheese varieties adapted to the habits and the culture of each region of the world : examples of this are fresh, soft and semi-hard cheeses such as Pavé d'Affinois, Saint-Paulin in France [11,21], Feta in Denmark and in Iran [50], Minas Frescal in Brazil [49, 47], Quark in Germany [33]; Twarog in Poland [32]; Teleme in Greece [48]; Ricotta and Cream cheese in the USA $[4,29]$ as well as hard cheeses such as Cheddar or Swiss cheese through the LCR concept $[13,30]$. Economic advantages explain the success of the MMV process. Indeed yields are significantly increased (up to 20\%) because the whey proteins are incorporated into the drained curd, there are reduced rennet requirements, reduced fat losses in whey and a simplification of the cheesemaking process [11, 23, 34]. Moreover, the differential concentration of milk proteins and fat before coagulation leads to a smoother and more homogeneous texture of UF-cheeses compared to homologous traditional cheeses $[23,24]$. Such an interesting property has led to new cheese varieties.

However, for matured UF-cheese varieties, made from five-fold or fully concentrated milk, proteolysis and the general extent of ripening were shown to be far slower compared to traditional cheeses [39, 20]. This disadvantage was often attributed to the presence of whey proteins in the UFcheeses $[20,23,2]$. However, this hypothesis is still controversial [30]. Indeed, the main reason for this retarded maturation is likely to be due to the high buffering capacity of UF-cheeses which retards the rate of lactic starter autolysis [11] and consequently the hydrolysis of the casein network. The negative role of the high level of calcium salts in UF-cheeses was emphasized as early as 1974 by Brulé et al. [3], suggesting several suitable ways to adjust 
the mineral content of UF-retentate: reduction of milk $\mathrm{pH}$ before or during ultrafiltration, increase of ionic strength by addition of $\mathrm{NaCl}$, or both methods [30]. Whey proteins in MMV cheeses are mainly an inert filler, as suggested by Koning et al. [20], because they are resistant to hydrolysis by chymosin, lactic starter bacterial proteases and plasmin $[14,20,35]$. The high content of $\beta$-lactoglobulin in UF-cheeses could also inhibit protease activity $[2,18]$.

To accelerate the ripening rate in UFcheeses, the same methods used to improve the ripening of traditional cheeses can be attempted : (i) elevation of storage temperature; (ii) addition of attenuated starters [19]; (iii) addition of cell-free extracts of starter bacteria [8]; (iv) increase of microbial population or non-starter bacteria; (v) addition of proteases and lipases or (vi) a combination of methods $[9,6,7]$. Some of these methods have been assessed. Hickey et al. [15] added a proteolytic strain, Lactobacillus helveticus YB1, with the normal starter. They reported that the level of free amino acids in UFcheese was increased to that observed with strain L. lactis subsp. cremoris E8 alone in traditional Cheddar cheese. Goudédranche et al. [12] improved the texture and the flavor of UF-Saint-Paulin and Camembert cheeses by adding 0.5 or $1.0 \mathrm{~g} \cdot \mathrm{kg}^{-1}$ of lysozyme to liquid pre-cheese. They observed a slight increase in proteolysis during ripening and an improvement of the organoleptic qualities of the UF-cheese. Bastian et al. [1], by the addition of urokinase to UF-Havarti and SaintPaulin cheeses in order to activate plasmin, observed an increase of NPN and NCN levels and a greater degradation of $\beta$-casein, which they correlated with a slightly improved flavor. Spangler et al. [39] accelerated the ripening of UF-Gouda cheese by adding a mixture of liposome- entrapped enzyme and freeze-shocked Lactobacillus helveticus. They observed a significant increase in TCA- and PTA-soluble nitrogen and more intense flavor without bitter flavor development.
To our knowledge, the addition of extra amounts of starter proteinases and peptidases, as suggested by Bech [2] in order to increase the hydrolysis of casein, has not yet been described. UF-retentates are interesting materials because all the added pool of enzymes is retained in the curd and in the subsequent cheese, which is a strong advantage compared to traditional cheesemaking where $90 \%$ of the added enzymes are lost in the whey.

The objective of this study was to investigate the impact on the ripening of UFSaint-Paulin cheeses of adding crude broken suspensions (CBS, a mixture of whole cells, cell walls and cell-free extract) or cell-free extract alone (CFE) of Lactococcus sp. or Propionibacterium freudenreichii. Cells were broken by using a new pilot high pressure homogenizer, as recently described [37].

\section{MATERIALS AND METHODS}

\subsection{Origin of the strains and growth conditions}

A freeze-dried commercial mixture of Lactococcus lactis subsp. lactis, L. lactis subsp. cremoris and L. lactis subsp. diacetylactis (MM 101 - EZAL) was obtained from Rhodia-Texel (Dangé StRomain, France) and kept at $4{ }^{\circ} \mathrm{C}$. Propionibacterium freudenreichii TL 24 (CNRZ 725) was obtained from the culture collection of the Laboratoire de Recherches de Technologie Laitière (INRA Rennes, France). It was stored at $-18{ }^{\circ} \mathrm{C}$ on YEL [27] containing glycerol $(15 \% \mathrm{v} / \mathrm{v})$ and cultivated on the same medium at $30^{\circ} \mathrm{C}$.

\subsection{Preparation of cell suspensions and cell disruption by a pilot homogenizer}

Freeze-dried Lactococcus sp. MM 101/10u $(10 \mathrm{~g})$ was suspended in $100 \mathrm{~mL}$ of $\mathrm{RO}$ sterile water $\left(3.5 \times 10^{10} \mathrm{cfu} \cdot \mathrm{mL}^{-1}\right)$. 
Propionibacterium freudenreichii TL 24 was first cultivated in YEL broth for $24 \mathrm{~h}$ at $30^{\circ} \mathrm{C}\left(\mathrm{OD}_{650} \sim 1\right)$, cells were harvested by centrifugation $\left(9.000 \mathrm{~g}, 10 \mathrm{~min}, 4^{\circ} \mathrm{C}\right)$ and suspended in $240 \mathrm{~mL}$ RO sterile water to achieve a cell concentration of $2.5 \times$ $10^{10} \mathrm{cfu} \cdot \mathrm{mL}^{-1}$. Suspensions $(75 \mathrm{~mL})$ of both $P$. freudenreichii TL 24 and lactococci cells were subjected to the disrupting effect of a pilot homogenizer Stansted/fluid power LTD (Sodexim, Muizon, France) at a pressure of $200 \mathrm{mPa}$, as described elsewhere [37]. Thirty millilitres of the treated suspension containing whole cells, broken cells and a pool of enzymes were collected and named "crude broken suspension" (CBS). The rest of the suspension was centrifuged $\left(10.000 \mathrm{~g}, 15 \mathrm{~min}, 4^{\circ} \mathrm{C}\right)$ to remove whole cells and large cell wall fragments. Thirty millilitres of the supernatant were collected and named "cell free extract" (CFE). The efficiency of cell disruption was verified by cell viability in specific medium culture and by cell dry weight, before and after homogenization, as described by Saboya et al. [37].

\subsection{Ultrafiltration and manufacture of UF-cheese}

Two sets of experiments were conducted with different UF devices as described below. In both cases, the milk was first standardized at $2.8 \%$ fat and pasteurized at $90^{\circ} \mathrm{C} / 4 \mathrm{~s}$ (Actijoule pilot, Société Actini, Evian, France). The temperature during the UF process was $48-50^{\circ} \mathrm{C}$. Dilution of the retentate (addition of $\mathrm{RO}$ water $1.12 \mathrm{vol} / \mathrm{vol}$ ) was done when the six-fold retentate achieved a concentration. The UF was continued until a retentate with a T.S. content of $40 \mathrm{~g}$ per $100 \mathrm{~g}$ was obtained. The retentate wasthen cooled to $30^{\circ} \mathrm{C}$ and inoculated with a Lactococcus starter, MMl 01. Freeze-dried powder was diluted to achieve $10^{7} \mathrm{cfu} \cdot \mathrm{mL}^{-1}$ of retentate. $\mathrm{NaCl}$ was then added to $0.75 \%(\mathrm{w} / \mathrm{w})$. The fermentation was conducted for $18 \mathrm{~h}$ at $30^{\circ} \mathrm{C}(\mathrm{pH}$ reached : $5.1-5.2$ ), and a further $0.65 \%$ of $\mathrm{NaCl}$ was added. The retentate was divided into several parts and treated with CBS and CFE as described below.

For the experiments involving homogenized MM101-Lactococcus cells as additive (LAC trial), the milk was ultrafiltrated using CARBOSEP M1 pilot UF equipment ( $150 \mathrm{~kg} \cdot \mathrm{mol}^{-1}$ cut-off membrane and a surface of $6.8 \mathrm{~m}^{2}$ - Société Rhodia-Orelis, Miribel, France) for $80 \mathrm{~min}$. The retentate was divided into four lots of $6 \mathrm{~kg}$ and treated as follows :

a) UF-control cheese $=$ retentate $+30 \mathrm{~mL}$ RO water;

b) UF / CBS Lact $5 \mathrm{~mL}=$ retentate $+5 \mathrm{~mL}$ lactococci $\mathrm{CBS}+25 \mathrm{~mL} \mathrm{RO}$ water;

c) UF / CBS Lact $30 \mathrm{~mL}=$ retentate + $30 \mathrm{~mL}$ lactococci CBS;

d) UF / CFE Lact $30 \mathrm{~mL}=$ retentate $+30 \mathrm{~mL}$ lactococci CFE.

For the experiment involving broken cells of $P$. freudenreichii as additive, a MEMBRALOX membrane UF pilot equipment was used $(0.05 \mu \mathrm{m}$ pore size membrane and a surface of $1.8 \mathrm{~m}^{2}$ - Société T.I.A., Bollene, France). The UF process was conducted for $120 \mathrm{~min}$. The retentate was divided into three $6 \mathrm{~kg}$ lots and treated as follows:

a) UF-control cheese $=$ retentate + $30 \mathrm{~mL}$ RO sterile water;

b) UF / CBS Prop $30 \mathrm{~mL}=$ retentate $+30 \mathrm{~mL}$ P. freudenreichii CBS;

c) UF / CFE Prop $30 \mathrm{~mL}=$ retentate $+30 \mathrm{~mL}$ P. freudenreichii CFE.

Rennet extract $(1.8 \mathrm{~mL})$ diluted fivefold with RO water(SKW Biosystems) was added to each retentate which was then set in a mould of $26 \times 36 \times 10.5 \mathrm{~cm}$. Two hours later, when the pre-cheeses became firm, they were cut into 12 blocks of $10 \times 9 \times$ $8.5 \mathrm{~cm}$ and incubated for $4 \mathrm{~h}$ at $30^{\circ} \mathrm{C}$; then, the cheeses were taken from the moulds and held at $12^{\circ} \mathrm{C}$ for 5 weeks. After three days, the cheeses were packed with a 
plastic film. Some of the cheeses treated with $P$. freudenreichii TL 24 CBS were ripened at $20{ }^{\circ} \mathrm{C}$ after $10 \mathrm{~d}$ at $12{ }^{\circ} \mathrm{C}$.

\subsection{Chemical composition of UF-cheeses}

Samples of cheese were taken after 1,7, 13, 20 and $27 \mathrm{~d}$. At day one, pH, Total Solids (TS), fat, salt, lactose and total nitrogen (TN) were determined. The $\mathrm{pH}$ was measured with a standard $\mathrm{CG} 837 \mathrm{pH}$ meter with InLAB 427 electrodes (Mettler Toledo, Viroflay, France) by direct insertion into the cheeses. TS were estimated by drying at $102( \pm 2){ }^{\circ} \mathrm{C}$ for $7 \mathrm{~h}$, according to IDF [16]. Fat was determined using the acid butyrometric methods of Van Gulik [17]. Salt was determined using a "Chlonuremetre Corming 926" (Humeau Laboratoires, La Chapelle-sur-Erdre, France). The residual lactose in the cheeses was measured by the phenol-sulfuric acid colorimetric assay of Dubois et al. [5]. Total nitrogen (TN) in cheese was determined by the Kjeldahl method and a convertion factor of 6.38 .

Protein breakdown in the cheeses was measured over 5 weeks by the evolution of soluble nitrogen at $\mathrm{pH} 4.6$ (non-casein nitrogen or NCN) or $12 \%$ TCA-soluble $\mathrm{N}$ (non-protein nitrogen or NPN), according to Rowland [36]. The results were expressed as a percentage of total nitrogen content in the cheese.

\subsection{Bacteriological analysis}

Cheese samples $(10 \mathrm{~g})$ were taken at different times of ripening and diluted in $90 \mathrm{~g}$ of trisodium citrate (20 g. $\left.\mathrm{L}^{-1}\right)$ using a Waring Blendor (Prolabo, 94126 Fontenaysous-Bois, France) at low speed for $20 \mathrm{~s}$ and then at high speed for $40 \mathrm{~s}$. Decimal dilutions were prepared with the same solution. Viability of Lactococcus was determined by the spread plate technique on M17 agar plates [40] after incubation at $30^{\circ} \mathrm{C}$ for 48 h. Viability of Propionibacterium was determined using a selective medium LGA
[26]; the LGA plates were incubated anaerobically at $30^{\circ} \mathrm{C}$ for $5-6 \mathrm{~d}$. The results were expressed as logarithm (log) of colony forming units (cfu) per $g$ cheese.

\subsection{Aqueous cheese extracts}

Soft aqueous cheese extracts were obtained as described by Valence et al. [46]. The cheese samples $(4.5 \mathrm{~g})$ were diluted in $18 \mathrm{~mL} \mathrm{RO}$ water and homogenized manually in plastic bags with filters (Humeau, $\mathrm{La}$ Chapelle-sur-Erdre, France). The solution was harvested and centrifuged at $10.000 \mathrm{~g}$ and $4{ }^{\circ} \mathrm{C}$ for $15 \mathrm{~min}$. The supernatant, i.e., the aqueous extract, was filtered through a $0.45 \mu \mathrm{m}$ membrane filter (Sartorius, 91127 Palaiseau, France) and stored at $-18^{\circ} \mathrm{C}$ until used.

\subsection{SDS-PAGE analysis}

Proteins in the aqueous cheese extracts, as well as CBS and CFE, were analyzed by denaturing polyacrylamide gel electrophoresis (SDS-PAGE), as described by Valence and Lortal [44]. Samples were mixed (v/v) in Laemmli buffer and loaded on the gel ( $14 \%$ separating gel). Migration was carried out at $25^{\circ} \mathrm{C}$ at a constant voltage of $180 \mathrm{~V}$ for $1.5 \mathrm{~h}$.

\subsection{Starter autolysis}

Autolysis of Lactococcus starters was monitored during ripening using antibodies against cell-free extracts of $L$. cremoris (LC-cytosol). For this purpose, cells of L. cremoris CNRZ 205 (type strain) were collected during the exponential growth phase $\left(\mathrm{OD}_{650}\right.$ of 0.8$)$ by centrifugation $\left(7.000 \mathrm{~g}, 20 \mathrm{~min}, 15^{\circ} \mathrm{C}\right.$ ) and washed twice in cold $\mathrm{RO}$ water $(15 \%$ of the initial culture). Then the pellets were stored for $48 \mathrm{~h}$ at $-20^{\circ} \mathrm{C}$ before being resuspended in cold sterile water $(6 \%$ of the initial volume of broth) and submitted to $138 \mathrm{mPa}$ for $3 \mathrm{~min}$ in a precooled French press apparatus (two 
runs). Suspensions were centrifuged $\left(48.000 \mathrm{~g}, 30 \mathrm{~min}, 4{ }^{\circ} \mathrm{C}\right)$ to eliminate unbroken cells and cell wall particles. The supematant was ultracentrifuged at $150.000 \mathrm{~g}$ for $3 \mathrm{~h}$ at $4{ }^{\circ} \mathrm{C}$ to eliminate ribosomes. The supematant obtained was called LC-cytosol. Polyclonal antibodies were produced by two rabbits against entire LC-cytosol obtained as described above $(100 \mu \mathrm{g}$ of protein per injection, 6 weeks of immunization) (Eurogentec, Seraing, Belgique).

Aqueous extracts of cheese were subjected to SDS-PAGE, followed by Westem blotting transfer ( $1 \mathrm{~h} 15$, constant current $250 \mathrm{~mA}$ ) onto a nitrocellulose sheet $(0.45 \mu \mathrm{m}$ pore size, Millipore, $78051 \mathrm{St}-$ Quentin-en-Yvelines, France) [43]. Cytosolic proteins of $L$. cremoris were detected using rabbit serum anti-LC-cytosol (stored at $-30{ }^{\circ} \mathrm{C}$ and diluted at 1:2500 in PBS-tween just before use). Horseradish peroxidaseconjugated goat anti-rabbit IgG $(\mathrm{H}+\mathrm{L})$ HRP conjugate (Biorad) was used as the secondary antiserum with DAB (3,3'diaminobenzidine tetrahydrochlorine) (Amresco, Solon, USA) as visualizer [45].

\subsection{Free amino acids}

The free amino acid content was determined after deproteinization of the sample by sulfosalicylic acid (Merk-Eurolab, Grosseron S.A., Saint Herblain, France) according to Mondino et al. [31]. Aqueous cheese extracts $(1 \mathrm{~mL})$ were treated with $50 \mathrm{mg}$ of sulfosalicylic acid, shaken for $15 \mathrm{~s}$ and incubated for $1 \mathrm{~h}$ at $4{ }^{\circ} \mathrm{C}$. The mixtures were centrifuged at $5.000 \mathrm{~g}$ for $15 \mathrm{~min}$ at $4{ }^{\circ} \mathrm{C}$. Supernatants were filtered through a $0.45 \mu \mathrm{m}$ membrane (Sartorius, 91127 Palaiseau, France) and the filtrate was diluted six-fold with a $0.2 \mathrm{~mol} \cdot \mathrm{L}^{-1}$ lithium citrate buffer, $\mathrm{pH} 2.2$ before injection. Amino acid analysis by ion exchange chromatography was carried out using a Pharmacia LKB Alpha Plus Aminoacid Analyser (Amersham Pharmacia Biotech Europe
GMBH, Orsay, France), as described by Spackman et al. [38].

\subsection{Neutral volatile compounds (GC-MS profiles)}

Cheese samples were thawed just before analysis and diluted (1:5) with sodium citrate $\left(0.5 \mathrm{~mol} \cdot \mathrm{L}^{-1}, \mathrm{pH} 8.8\right)$. Neutral volatile compounds were analyzed by head-spaceGC-MS, as described by Thierry et al. [41]. Seven grams of cheese were weighted in a 35 mL-non-fritted sparger. Briefly, compounds were trapped on a Vocarb 3000 trap (Supelco, Bella Fonte, PA, USA) thermally desorbed at $250^{\circ} \mathrm{C}$, cryofocused at $-100^{\circ} \mathrm{C}$ before being injected and separated on a HP5 capillary column (Agilent Technologies $60 \mathrm{~m} \times 0.32 \mathrm{~mm} 1 \mu \mathrm{m}$ film thickness). They were detected by a HP7972A quadruple mass spectrometer (Agilent Technologies, Les Ulis, France) after ionization by electronic impact and identified either by comparison of spectra with those of Nist $75 \mathrm{~K}$ Mass Spectral Database and/or spectra and retention times with those of reference compounds.

\section{RESULTS}

\subsection{Cell breaking by high pressure homogenization}

A pressure of $200 \mathrm{mPa}$ has been shown to be highly efficient for breaking Grampositive cells, including lactococci and propionibacteria used in this study, without completely denaturing intracellular cheeserelated enzymes [37]. In this work, the survival rate was similar to those obtained previously, $4.6 \%$ for lactococci and $28.8 \%$ for propionibacteria. Thus, in the lactococcal CBS, $1.6 \times 10^{9}$ cells $\cdot \mathrm{mL}^{-1}$ were still viable ( $4.6 \%$ of the initial value), mixed with the intracellular content from $3.3 \times 10^{10}$ broken cells $\cdot \mathrm{mL}^{-1}$. In the case of $P$. freudenreichii $\mathrm{CNRZ} 725$, the $\mathrm{CBS}$ contained 
$7.2 \times 10^{9}$ live cells. $\mathrm{mL}^{-1}$ as well as the celJular content from $1.75 \times 10^{10}$ broken cells $\mathrm{mL}^{-1}$.

CBS and CFE exhibited the same protein profiles when compared by SDS-PAGE just after homogenization, indicating that soluble proteins were not significantly lost during the centrifugation step (data not shown). Thus, CBS and CFE differed mainly by the presence of viable cells in CBS.
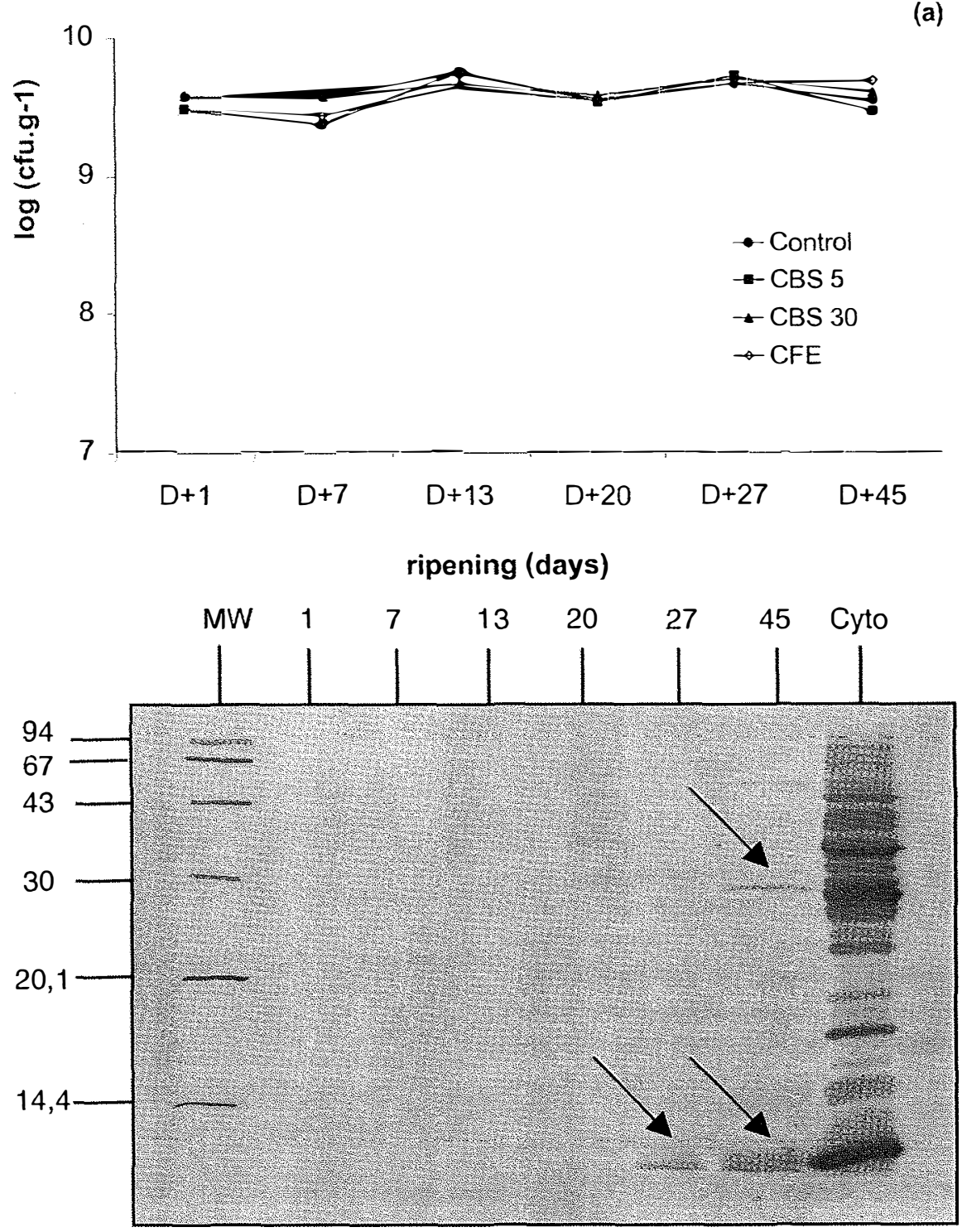

(b)

Figure 1. (a) Enumeration of Lactococcus sp. in UF-cheeses at $12^{\circ} \mathrm{C}$ during ripening period ( Control; CBS 5; $\mathbf{A}$ CBS 30; $\bigcirc \mathrm{CFE}$ ). (b) Immunodetection of Lactococcus cytoplasmic proteins in the control; the age in days of the cheeses was indicated on each lane ( $\mathrm{MW}=$ Molecular weight, $\mathrm{kDa}$; Cyto $=$ cytoplasmic proteins of Lactococcus lactis $)$. 


\subsection{Chemical composition of one-day-old UF-cheeses}

The composition of the control and experimental cheeses at day one were identical, i.e.: pH $5.23( \pm 0.02), 40.4 \%( \pm 0.1)$ total solids, $16.4 \%( \pm 0.1)$ fat, $1.5 \%( \pm 0.04)$ salt and protein $18.9 \%( \pm 0.5)$. The residual lactose was less than $1 \mathrm{~g} \cdot \mathrm{kg}^{-1}$ at day one, due to the diafiltration treatment. The chemical composition was thus in agreement with previous data for UF-St-Paulin cheese [11].

\subsection{Bacterial populations during cheese ripening}

Populations of Lactococcus starter were identical at day one in all cheeses (control and experimental), i.e. around 3-4.0 $\times$ $10^{9} \mathrm{cfu} \cdot \mathrm{g}^{-1}$ (Figs. 1 and 2). No decrease in viability was noted over 6 weeks of ripening. The absence of lysis of Lactococcus starter was confirmed by immunoblotting of the aqueous extracts from one to 45 daysold using antibodies anti-LC cytosol. No intracellular proteins were detected either in the control or in the experimental cheeses until day 27; they then appeared weakly in the sample from 45-day-old cheese (Fig. 1b).

In the trials with propionibacteria, the initial number of $P$. freudenreichii was around $10^{7} \mathrm{cfu} \cdot \mathrm{g}^{-1}$ of cheese in the CBStreated cheese and only $10^{2} \mathrm{cfu} \cdot \mathrm{g}^{-1}$ in CFEtreated cheese (Fig. 2). No change was noted when the cheeses were ripened at $12^{\circ} \mathrm{C}$ but a slight growth of propionibacteria occurred when cheeses were incubated at $20^{\circ} \mathrm{C}$, $+1.2 \log$ unit in the CBS-treated cheese. In the blank without additive, no propionibacteria were detected at day one, and less than $100 \mathrm{cfu} \cdot \mathrm{g}^{-1}$ at the end of ripening.

In the trials with broken lactococci, it was not possible to selectively enumerate the additional viable lactococci (in the CBS supplemented cheese) because the additive was identical to the starter used for cheesemaking. However, a theoretical calculation can be done as all cells and enzymes added are retained in the UFretentates: $30 \mathrm{~mL}$ of CBS (containing $1.6 \times 10^{9} \mathrm{cfu} \cdot \mathrm{mL}^{-1}$ lactococci) was added to $6 \mathrm{~kg}$ of retentate, and thus theoretically $6 \times 10^{6}$ cells of live Lactococcus cells were added / $g$ of retentate in the CBS assay, in parallel with the intracellular content of $1.6 \times 10^{8}$ cells. $\mathrm{g}^{-1}$. In the CFE supplemented cheese, the intracellular content corresponding to $1.6 \times 10^{8}$ cells. $\mathrm{g}^{-1}$ was added, but without a significant number of live cells.

\subsection{Impact on the ripening of the addition of broken propionibacteria}

When ripened at $12^{\circ} \mathrm{C}$, changes in the $\mathrm{pH}$ were the same in the experimental and control cheeses, increasing until day 20 from 5.2 to 5.35 . When ripening was performed at $20^{\circ} \mathrm{C}$, the change was the same until day 20 but then $\mathrm{pH}$ continued to increase in the cheese treated with CBS (pH 5.45).

In terms of proteolysis, the effect was limited and mainly dependant on the temperature of ripening. When the cheeses were ripened at $20^{\circ} \mathrm{C}, \mathrm{NCN} / \mathrm{NT} \%$ was $12 \%$ higher than in the cheeses at $12{ }^{\circ} \mathrm{C}$, but there was no further increase due to the addition of CBS or CFE (data not shown). A slight increase of NPN/NT \% compared to the control was noted at day 27 when CBS or CFE was added, but only at $20^{\circ} \mathrm{C}$ (Fig. 3). The sum of the free amino acids was $32.5 \mu \mathrm{mol} \cdot \mathrm{g}^{-1}$ of cheese in the control, and about $32.7 \mu \mathrm{mol} \cdot \mathrm{g}^{-1}$ and $34 \mu \mathrm{mol} \cdot \mathrm{g}^{-1}$ for CBS and CFE treated cheeses, respectively. The profiles at day 27 were very similar to the control except for slight qualitative differences: in the presence of CBS, Asn, Asp and His content decreased significantly, whereas Glu, Pro, Ala and 


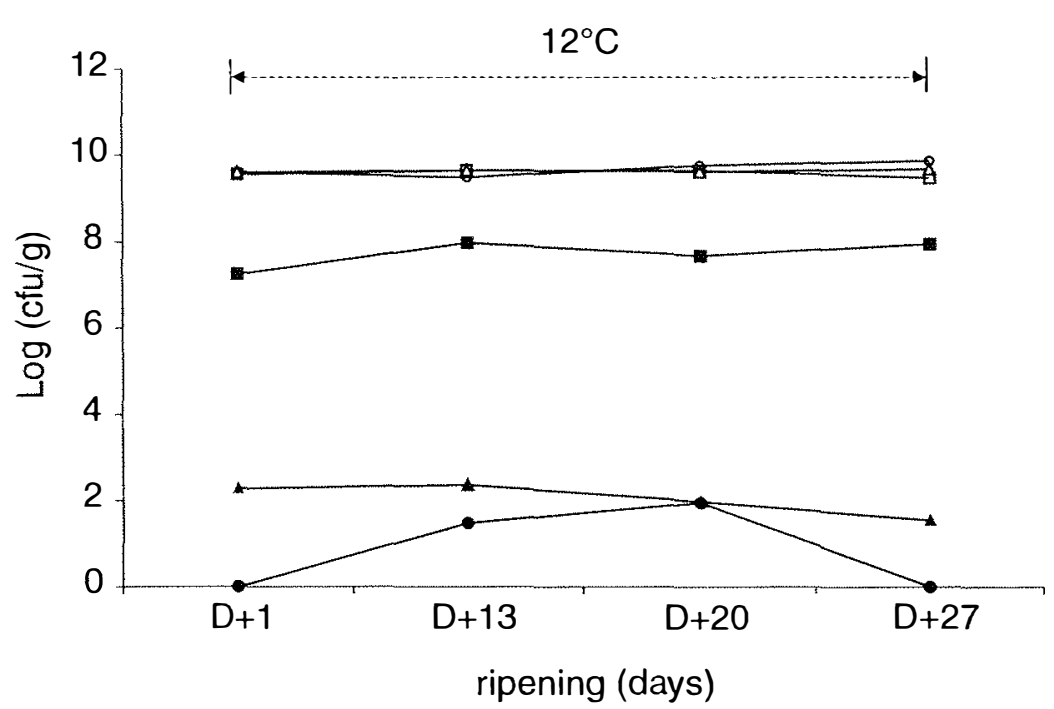

(a)

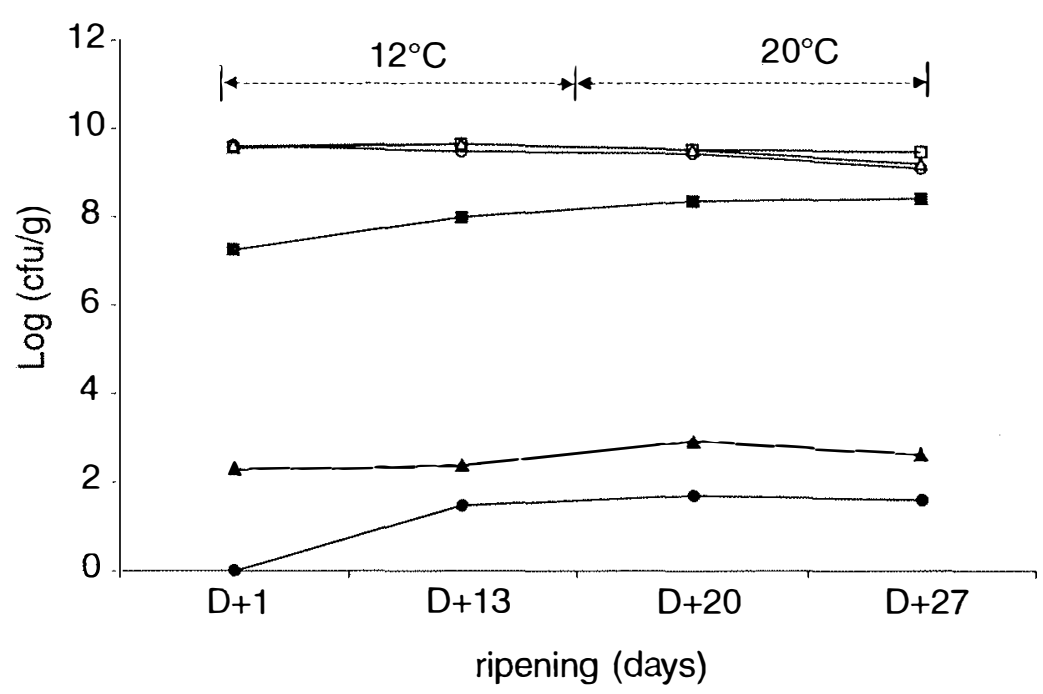

(b)

Figure 2. (a) Enumeration of Lactococcus sp. ( $\bigcirc$ Control; $\square \mathrm{CBS} ; \triangle \mathrm{CFE}$ ) and P. freudenreichii ( Control; $\mathrm{CBS} ; \mathbf{\Delta} \mathrm{CFE})$ in UF-cheeses treated with $P$. freudenreichii at $12^{\circ} \mathrm{C}$ and (b) at $20^{\circ} \mathrm{C}$ during ripening period.

Leu were present in larger amounts $(+15$ to $+40 \%$ ) (Fig. 4a).

Regarding neutral volatile aroma compounds, GC-MS analysis of control cheeses revealed relatively few compounds (Tab. I), mainly alcohols, some ketones and some aldehydes. In the presence of CBS, the amount of some of them increased (two- or eleven-fold), like 1-propanol, 1-butanol, 1pentanol, 3-methyl butanol, and 2-methyl butanol. Moreover, other compounds appeared, mainly esters and sulfur compounds like dimethyl disulfide (Tab. I). On the other hand, no significant effect of the CFE was observed in terms of neutral volatile aroma compounds, showing that live cells are required. 
(a)

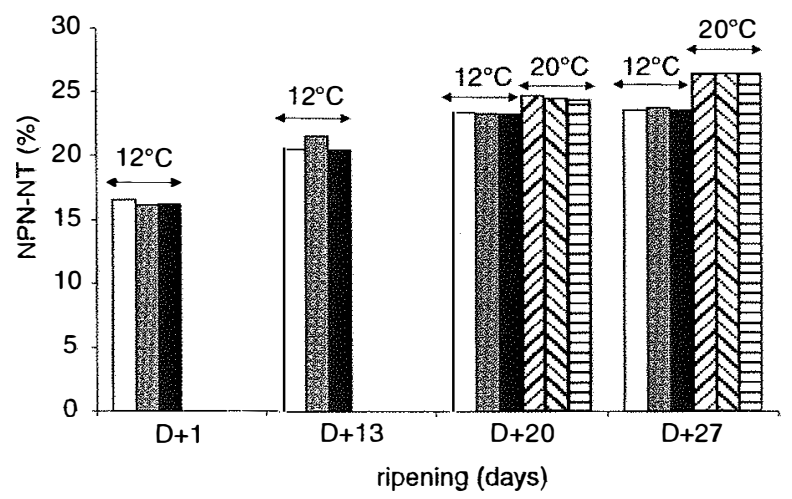

(b)

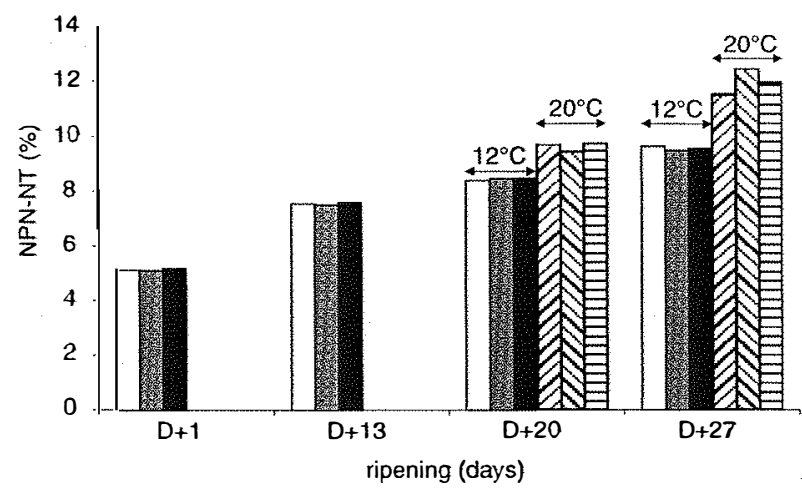

Figure 3. (a) NCN-NT (\%). (b) NPN-NT (\%) indexes in UF-cheese treated with P. freudenreichii and ripened at $12{ }^{\circ} \mathrm{C}(\square \mathrm{Control} ; \mathrm{CBS} ; \mathrm{CFE})$ or $20^{\circ} \mathrm{C}(\mathrm{Control} ; \mathrm{CBS} ; \mathrm{CFE})$.

\subsection{Impact of the addition of broken lactococci on ripening}

The same continuous increase of $\mathrm{pH}$ was observed until day 27 (5.2 to 5.5) for the blank and the cheeses treated with CBS or CFE. No significant effect was observed on primary proteolysis since no significant change in NCN/NT or NPN/NT indexes was noted. Also, SDS-PAGE analysis showed no differences in the profiles (data not shown). By contrast, an obvious impact on the free amino acids was observed(Fig. 4b). The sum of the free amino acids was $14.5 \mu \mathrm{mol} \cdot \mathrm{g}^{-1}$ for the control at day 27 , and, respectively, 20.5, 30.6 and $32.3 \mu \mathrm{mol} \cdot \mathrm{g}^{-1}$ of cheese with CBS $(5 \mathrm{~mL}), \mathrm{CBS}(30 \mathrm{~mL})$ and CFE. Qualitatively (Fig. 4b) the concen tration of most amino acids increased 1.5 to 3 times when CFE was added. The result was similar with CBS $(30 \mathrm{~mL})$ but slight differences can be observed in the profiles; the addition, in parallel with cytoplasmic content, of live Lactococci, had an influence on the release or catabolism of some amino acids. This result was surprising since the quantity added was relatively low $\left(6 \times 10^{6}\right.$ cells per $g$ of cheese $)$ compared to the high level of the starter itself $\left(10^{9} \cdot \mathrm{g}^{-1}\right)$.

Neutral volatile compounds were estimated at day 27 and also at day 45 . As in the aforementioned experiments, the control contained the same few aroma compounds. No increase and no new compounds were noted when CFE or CBS were added (data not shown). 

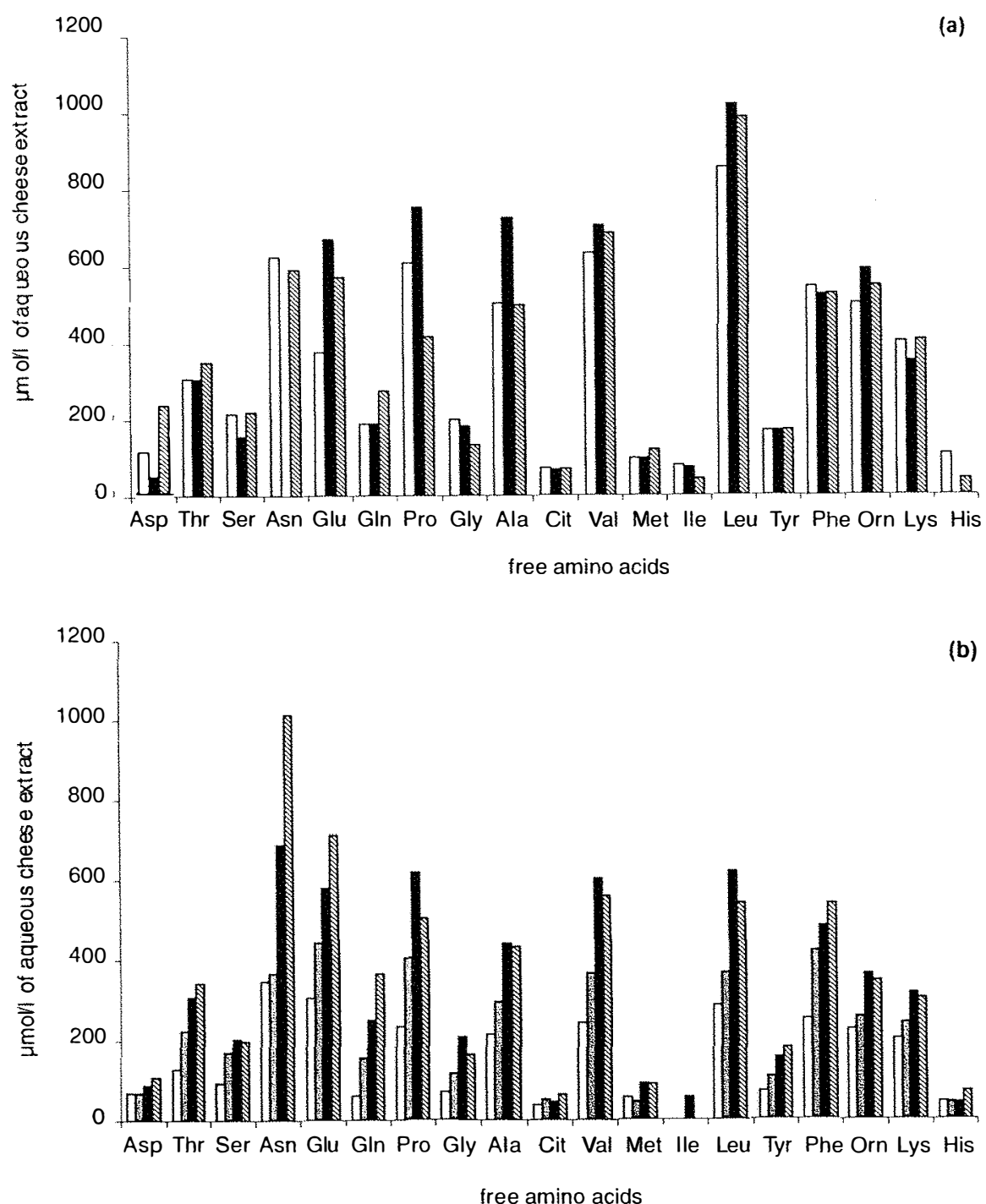

Figure 4. Free amino acid composition in the 27 day-old UF-cheese treated with $P$. freudenreichii (a) and ripened at $20^{\circ} \mathrm{C}(\square \mathrm{Control}$; $\mathrm{CBS}$; 目 CFE) and in the UF-cheese treated with Lactococcus $(\mathbf{b})$ at day 27 at $12^{\circ} \mathrm{C}$ ( $\square$ Control;

\section{DISCUSSION}

Both enumeration of viable cells of added starters and immunoblotting data related to intracellular enzyme markers confirm that in cheeses made from milk concentrated by UF at milk $\mathrm{pH}$, no lysis of Lactococcus starter was detected, as previously hypothesized by Goudédranche et al.
[12] and Mistry and Maubois [30]. Such a change in a phenomenon essential for the normal ripening of cheese can be related to the environmental conditions of Lactococcus in this type of UF-cheeses. The internal aqueous phase of UF-cheeses has a very high content in calcium salts [3] which limits the decrease in $\mathrm{pH}$ induced by lactic acid production by Lactococci and 
this could also inhibit lysis, as shown for Lactobacilli [25]. Relations between cellular lysis and the buffering capacity of the aqueous phase of cheese is a research area which should be studied more deeply.
Addition of broken cells obtained with the new high pressure homogenizer appears to be an interesting way to substitute lack of lysis of Lactococcus in UF-cheeses. Surprisingly, addition of CBS or CFE of

Table I. Values of areas of neutral volatile compounds identified by GC MS in the UF-cheese treated with $P$. freudenreichii (CBS and CFE) at day 27 at $20^{\circ} \mathrm{C}$.

\begin{tabular}{|c|c|c|c|c|}
\hline \multirow[t]{2}{*}{ Volatile Compounds } & \multirow{2}{*}{$\begin{array}{l}\text { Identification } \\
\text { Method }\end{array}$} & \multirow{2}{*}{$\begin{array}{l}\text { Control } \\
\times 10^{6}\end{array}$} & \multirow{2}{*}{$\begin{array}{l}\text { CBS } \\
\times 10^{6} \\
\end{array}$} & \multirow{2}{*}{$\begin{array}{l}\text { CFE } \\
\times 10^{6} \\
\end{array}$} \\
\hline & & & & \\
\hline \multicolumn{5}{|l|}{ Alcohols } \\
\hline 1-propanol & MS & 9 & 174 & 8 \\
\hline 1-butanol & MS & 97 & 242 & 62 \\
\hline 3-methyl butanol & MS/R & 1.4 & 3.4 & ND \\
\hline 2-methyl butanol & $\mathrm{MS} / \mathrm{R}$ & 2.1 & 31.9 & 0.4 \\
\hline 1-pentanol & MS & 2.5 & 5.5 & 1.5 \\
\hline \multicolumn{5}{|l|}{ Aldehydes } \\
\hline 3-methyl butanal & $\mathrm{MS} / \mathrm{R}$ & 10.4 & 1.7 & 3.3 \\
\hline \multicolumn{5}{|l|}{ Ketones } \\
\hline 2,3-butanedione & $\mathrm{MS} / \mathrm{R}$ & 90 & 175 & 103 \\
\hline 2,3-pentanedione & MS & 5 & 4 & 1.2 \\
\hline 2-pentanone & MS & 7.2 & 9.9 & 6.7 \\
\hline 2-hexanone & MS & 0.5 & 2.3 & 0.5 \\
\hline 2-heptanone & $\mathrm{MS} / \mathrm{R}$ & 11.2 & 17 & 10 \\
\hline 2-nonanone & $\mathrm{MS} / \mathrm{R}$ & 1.7 & 2.2 & 1.2 \\
\hline \multicolumn{5}{|l|}{ Esters } \\
\hline Ethyl acetate & MS & 3.8 & 4.5 & 1.7 \\
\hline Ethyl propanoate & MS & ND & 1.2 & ND \\
\hline Ethyl butanoate & $\mathrm{MS} / \mathrm{R}$ & 3.9 & 3.5 & 3.6 \\
\hline Propyl propanoate & MS & ND & 0.9 & ND \\
\hline Propyl butanoate & MS & ND & 1.3 & ND \\
\hline butyl butanoate & MS & 0.6 & 0.8 & 0.6 \\
\hline \multicolumn{5}{|l|}{ Sulfur Compounds } \\
\hline Dimethyl disulfide & $\mathrm{MS} / \mathrm{R}$ & ND & 2.85 & ND \\
\hline
\end{tabular}

$\mathrm{ND}=$ not detected

MS = identified by mass spectrum or comparison with data bank.

$\mathrm{MS} / \mathrm{R}=$ identified by mass spectrum or comparison with compound reference. 
Lactococcus did not significantly increase the NPN/NT ratio in the cheeses during ripening in spite of the significant increase in the concentration of free amino acids (1.5 to 3 times). Similar observations have been made by Hickey et al. [15] and by Spangler et al. [39] after the addition of $L b$. helveticus or freeze-shocked $L b$. helveticus cells, respectively. Stability of NPN content might be due either to complete destruction of the Lactococcus proteinase by homogenization; such a hypothesis appears highly unlikely considering the results observed by Saboya et al. [37] on cell enzymes submitted to the same technological treatment, or to an inhibition of this enzyme by a component concentrated by UF as proposed by Bech [2]. On the contrary, intracellular peptidases are still active and able to degradepeptides contained in UF-cheeses to free amino acids, as they do in traditional cheeses [22]. The lower increase in free amino acids observed after addition of CBS might be related to a partial consumption of the released amino acids by the remaining $10^{6} \mathrm{cfu} \cdot \mathrm{g}^{-1}$ live cells added to this suspension.

Addition of CBS or CFE from Lactococcus to UF-cheeses does not seem to produce more volatile compounds than in the control cheese. Such an observation confirms the low impact per se of Lactococcus intracellular enzymes on cheese flavor development [22].

Increase of ripening temperature from 12 to $20^{\circ} \mathrm{C}$, assayed in this study during the addition of Propionibacteria CBS or CFE, caused an increase in proteolysis of the casein network by $12 \%$ as measured by the NCN/NT ratio. This increase was probably due to the temperature activation of rennet and proteinase of live cells of the added starters [10]. Ripening at $20^{\circ} \mathrm{C}$ also induced peptide breakdown, as shown by the $19 \%$ increase of the NPN/NT ratio in the reference cheeses. Addition of Propionibacterium CBS to UF-cheeses caused only a slight additional degradation of peptides $(+8 \%)$ when ripened at $20^{\circ} \mathrm{C}$. No significant impact was seen with CFE. As was observed for experiments with Lactococcus, data for total free amino acids did not agree with peptidolysis results but a survey of individual amino acids demonstrates that disappearance of Asn, probably consumed by the remaining living cells of Propionibacterium in CBS, was the cause of this discrepancy.

Data obtained for volatile compounds showed no significant differences between the control and Propionibacterium CFE treated cheeses. On the other hand, addition of CBS induced a net increase of several compounds, including primary alcohols, esters, ketones and dimethyl disulfide, 2 methyl butanol and 3-methyl butanol, probably from the respective catabolism of Ile and Leu by Propionibacterium cells [42]. Propionic and acetic acids, which are the main products of Propionibacterium metabolism, were not determined in this study, but were very probably formed, resulting in the formation of ethyl and propyl esters of propanoic acid. Dimethyl disulfide can result from degradation of Met by Propionibacterium [42]. In addition, the presence of Propionibacterium was associated with a higher amount of some methyl ketones and of diacetyl (2,3-butanedione).

In conclusion, this work provides the first demonstration of the absence of Lactococcus starter lysis in UF-cheeses and confirmed the low extent of the ripening through the analysis of proteolysis and neutral volatile aroma compounds. On the other hand, it was shown that it is possible to modify these two ripening indices by adding broken cells obtained by high pressure homogenization, a technology which opens a new area of investigation to improve UF-cheese ripening. Other strains and species with efficient peptidase activity and higher flavoring ability should now be tested. 


\section{ACKNOWLEDGEMENTS}

This work was financially supported by the CAPES (Brasília, Brasil), FAPESP (São Paulo, Brasil) and by the Laboratoire de Recherches de Technologie Laitière (INRA, France). We are indebted to M-B. Maillard and A. Thierry for their valuable advice and help with aroma compounds analysis.

\section{REFERENCES}

[1] Bastian E.D., Hansen K.G., Brown R.J., Activation of plasmin with urokinase in ultrafiltered milk for cheese manufacture, J. Dairy Sci. 74 (1991) 3669-3676.

[2] Bech A.-M., Characterising ripening in UFcheese, Int. Dairy J. 3 (1993) 329-342.

[3] Brulé G., Maubois J.-L., Fauquant J., Étude de la teneur en éléments minéraux des produits obtenus lors de l'ultrafiltration du lait sur membrane, Lait 54 (1974) 600-615.

[4] Covacevich H.R., Kosikowski F.V., Cream cheese by ultrafiltration, J. Food Sci. 45 (1977) 1362-1364.

[5] Dubois M., Gilles K.A., Hamilton J.K., Rebers P.A., Smith F., Colorimetric method for determination of sugars and related substances, Anal. Chem. 28 (1956) 350-358.

[6] El Soda M., Accelerated maturation of cheese, Int. Dairy J. 3 (1993) 531-544.

[7] El Soda M., Pandian S., Recent developments in accelerated cheese ripening, J. Dairy Sci. 74 (1991) 2317-2335.

[8] Engels W.J.M., Visser S., Development of cheese flavour peptides and amino acids by cellfree extracts of Lactococcus lactis subsp. cremoris B78 in a model system, Neth. Milk Dairy J. 50 (1996) 3-17.

[9] Fox P.F., Acceleration of cheese ripening, Food Biotechnol. 2 (1989) 133-185.

[10] Fox P.F., Exogenous enzymes in dairy technology - a review, J. Food Biochem. 17 (1993) 173-199.

[11] Goudédranche H., Maubois J.-L., Ducruet P., Mahaut M., Utilisation de nouvelles membranes minérales d'ultrafiltration pour la fabrication de fromages du type Saint-Paulin, Tech. Lait. 950 (1981) 7-12.

[12] Goudédranche H., Ducruet P., Vachot J.-C., Pannetier R., Maubois J.-L., Utilisation du lysozyme en tant qu'agent régulateur de l'affinage en fromagerie MMV, Lait 66 (1986) 189-206.

[13] Green M.L., Glover F.A., Scurlock E.M.W., Marshall R.J., Hatfield D.S., Effect of use of milk concentrated by ultrafiltration on the manufacture and ripening of Cheddar cheese, J. Dairy Res. 48 (1981) 33-341.

[14] Gripon J.C., Desmazeaud M.J., Le Bars D., Bergere J.L., Étude du rôle des microorganismes et des enzymes au cours de la maturation des fromages. Il. Influence de la presure commerciale, Lait 55 (1975) 502-515.

[15] Hickey M.W., van Leeuwen H., Hillier A.J., Jago G.R., Amino acid accumulation in Cheddar cheese manufacture from normal and ultrafiltrated milk, Aust. J. Dairy Technol. 38 (1983) 110-113.

[16] IDF, Cheese and processed cheese. Determination of the total solids content. Standard 4A, Int. Dairy Fed., Brussels, Belgium (1982).

[17] IDF, Lait et produits laitiers. Détermination de la teneur en matière grasse. Standard $152 \mathrm{~A}$, Int. Dairy Fed., Brussels, Belgium (1997).

[18] Jameson G.W., Lelievre J., Effects of whey proteins on cheese characteristics, Bull. Int. Dairy Fed. 313 (1996) 3-8.

[19] Klein N., Lortal S., Attenuated starters : an efficient means to influence cheese ripenig - a review, Int. Dairy J. 9 (1999) 751-762.

[20] Koning P.J., Boer R., Both P., Nooy P.F.C., Comparison of proteolysis in a low-fat semi-hard type of cheese manufactured by standard and by ultrafiltration techniques, Neth. Milk Dairy J. 35 (1981) 36-46.

[21] Kosikowski F.V., Ultrafiltration of milk on French farms and in the making of a new specialty cheese industry, J. Dairy Sci. 68 (1985) 2403-2410.

[22] Law B.A., Wigmore A.S., Accelerated ripening of Cheddar cheese with a commercial proteinase and intracellular enzymes from starter streptococci, J. Dairy Res. 50 (1983) 519-525.

[23] Lawrence R.C., The use of ultrafiltration technology in cheesemaking. Bull. Int. Dairy Fed. 240 (1989) 1-15.

[24] Lelievre J., Lawrence R.C., Manufacture of cheese from milk concentrated by ultrafiltration, J. Dairy Res. 55 (1988) 465-478.

[25] Lortal S., Rousseau M., Boyaval P., van Heijenoort J., Cell wall and autolytic system of Lactobacillus helveticus ATCC 12046, J. Gen. Microbiol., 137 (1991) 549-559.

[26] Madec M.N., Rouault, A., Maubois J.-L., Thierry A., Milieu sélectif et procédé pour le dénombrement des bactéries propioniques, French Patent, FR 2700778 - Al, 1993.

[27] Malik A.C., Reinbold G.W., Vedamuthu E.R., Evaluation of the taxonomy of the Propionibacterium, Can. J. Microbiol. 14(1968) 1185-1191.

[28] Maubois J.-L., Kosikowski F.V., Making Ricotta cheese by ultrafiltration, J. Dairy Sci. 61 (1978) 881-884. 
[29] Maubois J.-L., Mocquot G., Vassal L., A method for processing milk and dairy products, French Patent, FR 2052 121, 1969.

[30] Mistry V.V., Maubois J.-L., Application of membrane separation technology to cheese production, in: Fox P.F., (Ed.), Cheese Chemistry Physics and Microbiology, Vol 1, General Aspects $2^{\text {nd }}$ ed. Chapman \& Hall London, 1993, pp. 493-522.

[31] Mondino A., Bongiovanni G., Fumero S., Rossi L., An improved method of plasma deproteinisation with sulphosalicylic acid for determining amino acids and related componds, J. Chromatogr. 74 (1972) 255-263.

[32] Omar M.M., Hosaja M., Microstructure and chemical changes in Twarog cheese made from UF-milk and from lactose hydrolyzed milk. Food Chem. 22 (1986) 147-163.

[33] Patel R.S., Reuter I., Prokopek D., Production of quarge by ultrafiltration, J. Soc. Dairy Technol. 39 (1986) 27-.31.

[34] Pedersen P.J., Ottosen N., Manufacture of fresh cheese by ultrafiltration, in: New applications of membrane process, Int. Dairy Fed. Special issue 9201, Brussels, Belgium (1992) 67-76.

[35] Qvist K.B., Thomsen D., Hoier E., Effect of ultrafiltered milk and use of different starters on the manufacture, fermentation and ripening of Havarti cheese, J. Dairy Res. 54 (1987) 437-446.

[36] Rowland S.J., The determination of the nitrogen distribution in milk, J. Dairy Res. 9 (1938) 42-46.

[37] Saboya L.V., Maillard M.-B., Lortal S., Efficient and easy mechanical disruption of Lactobacillus helveticus, Lactococcus lactis and Propionibacterium freudenreichii by a new pilot high pressure homogenizer (submitted).

[38] Spackman D.H., Stein W.H., Moore S., Automatic recording apparatus for use in chromatography of amino acids, Anal. Chem. 30 (1958) 1190-1206.

[39] Spangler P.L., El Soda M., Johnson M.E., Olson N.F., Amundson C.H., Hill Jr. C.G., Accelerated ripening of Gouda cheese made from ultrafiltered milk using a liposome entrapped enzyme and freeze shocked lactobacilli, Milchwissenschaft 44 (1989) 189-203.

[40] Terzaghi B.E., Sandine W.E., Improved medium for lactic streptococci and their bacteriophages, Appl. Microbiol. 29 (1975) 807-813.
[41] Thierry A., Maillard M.-B., Le Quéré J.-L., Dynamic headspace analysis of Emmental aqueous phase as a method to quantify changes in volatile flavour compounds during ripening, Int. Dairy J. 9 (1999) 453-463.

[42] Thierry A., Maillard M.-B., Production of cheese flavour compouds derived from amino acid catabolism by Propionibacterium freudenreichii: a review, Lait 82 (1).

[43] Towbin H., Staehelin T., Gordon J., Electrophoretic transfer of proteins from polyacrylamide gels to nitrocellulose sheets: procedure and some applications, Proc. Nat. Acad. Sci. 76 (1979) 4350-4354.

[44] Valence F., Lortal S., Zymogram and preliminary characterization of Lactobacillus helveticus autolysins. Appl. Environ. Microbiol. 61 (1995) 3391--3399.

[45] Valence F., Richoux R., Thierry A., Palva A., Lortal S., Autolysis of Lactobacillus helveticus and Propionibacterium freundenreichii in Swiss cheese: first evidence by using species specific markers, J. Dairy Res. 65 (1998) 609-620.

[46] Valence F., Deutsch S.M., Richoux R., Gagnaire V., Lortal S., Autolysis and related proteolysis in Swiss cheese for two Lactobacillus helveticus strains, J. Dairy Res. 67 (2000) 261--271.

[47] van Dender A.G.F., Massaguer-Roig S., Campos S.D.S., Physical-chemical changes and shelflife of traditional and MMV "Minas Frescal" cheese, Anais do XVI Congresso Nacional de Laticínios, Juiz de Fora, ln: Revista do Instituto de Laticínios "Cândido Tostes" 54 (1999) pp. 67-82.

[48] Veinoglou B.C., Boyazoglu E.S., Improvement in the quality of Teleme cheese produced from ultrafiltered cow's milk, J. Soc. Dairy Technol. 35 (1982) 54-56.

[49] Vieira S.D.A., Goudédranche H., Ducruet P., Maubois J.-L., Éléments de fabrication d'un nouveau fromage brésilien de type "Minas Frescal" par le procédé M.M.V., Techn. Lait. 978 (1983) 17-20.

[50] Wagner J., Rubin J., Ultrafiltration of milk for production of Feta cheese and hydrolysis of lactose by enzymes, in: Proceedings of the Second International Congress on Engineering and Food. Helsinki, Finland (1979) pp. 27-31. 